\title{
A systematic study of enzyme-nanomaterial interactions for application in active surface decontamination
}

\author{
Alan Steven Campbell \\ West Virginia University
}

Follow this and additional works at: https://researchrepository.wvu.edu/etd

\section{Recommended Citation}

Campbell, Alan Steven, "A systematic study of enzyme-nanomaterial interactions for application in active surface decontamination" (2013). Graduate Theses, Dissertations, and Problem Reports. 538.

https://researchrepository.wvu.edu/etd/538

This Thesis is protected by copyright and/or related rights. It has been brought to you by the The Research Repository @ WVU with permission from the rights-holder(s). You are free to use this Thesis in any way that is permitted by the copyright and related rights legislation that applies to your use. For other uses you must obtain permission from the rights-holder(s) directly, unless additional rights are indicated by a Creative Commons license in the record and/ or on the work itself. This Thesis has been accepted for inclusion in WVU Graduate Theses, Dissertations, and Problem Reports collection by an authorized administrator of The Research Repository @ WVU. For more information, please contact researchrepository@mail.wvu.edu. 


\title{
A SYSTEMATIC STUDY OF ENZYME- NANOMATERIAL INTERACTIONS FOR APPLICATION IN ACTIVE SURFACE DECONTAMINATION
}

\author{
Alan Steven Campbell \\ Thesis submitted to the Benjamin M. Statler College of Engineering and Mineral \\ Resources at West Virginia University \\ in partial fulfillment of the requirements \\ for the degree of

\section{Master of Science \\ in \\ Chemical Engineering}

Cerasela Zoica Dinu, Ph.D., Chair

Nianqiang Wu, Ph.D.

Charter Stinespring, Ph.D.

Morgantown, West Virginia

2013

Keywords: Enzyme-Nanomaterial Interaction, Immobilization, Carbon-based Materials, Chloroperoxidase, Decontamination 


\section{ABSTRACT \\ ENZYME-NANOMATERIAL INTERACTIONS: PERSPECTIVES, APPLICATIONS AND OPPORTUNITIES}

\section{Alan Steven Campbell}

Enzymes are a catalytic class of proteins that possess high specificity, selectivity and biocompatibility, which makes them ideal for multiple applications in industrial production and biotechnology. However, the use of enzymes in such applications is limited due to their low operational stability and increased cost attributed to difficulty of purification and reuse. Immobilization of enzymes onto nano-sized solid supports has emerged as a potential solution to these shortcomings with a trade-off of a percentage of activity loss upon immobilization. Herein, a comprehensive study of enzyme immobilization techniques with emphasis on active-surface decontamination applications is presented.

In Chapter 1, an overview of the potential uses of enzymes and enzyme immobilization techniques is given. Benefits of enzyme-nanosupport conjugates in industrial catalysis, energy production (i.e. biofuels and biofuel cells), biosensing and bioactive coatings are discussed with emphasis on enzyme-based decontamination coatings. It is emphasized that enzyme-based conjugates are capable of increasing enzyme stability at operational conditions used in industrial production of fine chemicals, pharmaceuticals and foods. Also, this Chapter emphasizes the benefits of enzyme immobilization in regard to the development of the next generation of biosensors with enhanced selectivity and specificity or biofuel cells that do not require a membrane, and thus allow miniaturization. Additionally, coatings capable of decontaminating pathogens such as bacteria and spores can be produced through the incorporation of enzymenanomaterial conjugates. Finally, the chapter provides new perspectives and future directions in enzyme-based biotechnology. A. Campbell, C. Dong, C. Xiang, N. Q. Wu and C. Z. Dinu, "Enzyme-Based Technologies: Perspectives and Opportunities" Accepted to Green Polymer Chemistry: Biocatalysis and Biomaterials, ACS Symposium Series 2012.

In Chapter 2, the impacts of the reactions that take place upon enzyme immobilization at the nanointerface are discussed and the effects of multiple variables present in the immobilization process on enzyme retained activity are identified. These variables include nanosupport characteristics (i.e. physical and chemical properties, rate of curvature), enzyme properties (i.e. 
surface properties, molecular weight, isoelectric point) and immobilization technique (i.e. chemical or physical binding). Prior to immobilization of the selected enzymes (i.e. soybean peroxidase (SBP), chloroperoxidase $(\mathrm{CPO})$ and glucose oxidase $\left(\mathrm{GO}_{\mathrm{X}}\right)$ ) all nanosupports (i.e. single-walled carbon nanotubes (SWCNTs), multi-walled carbon nanotubes (MWCNTs) and graphene oxide nanosheets $(\mathrm{GON})$ ) are chemically functionalized under user-controlled conditions through strong acids treatment and characterized in terms of structure and morphology. A comparison of how the characteristics of both the nanosupports used as well as immobilization technique employed affect retained activity in an enzyme specific manner is also presented. A. Campbell, C. Dong, J. Hardinger, F. Meng, G. Perhinschi, N. Q. Wu and C. Z. Dinu, “Activity and Kinetics of Immobilized Enzyme Depend on the Enzyme-Interface Reaction” To be submitted to Langmuir.

In Chapter 3, the development of a self-decontaminating enzyme-nanosupport hybrid system is presented. This system is based on the generation of the strong decontaminant hypochlorous acid (HOCl) by CPO. Two strategies are investigated. First, the production of the required substrate (i.e. hydrogen peroxide $\left.\left(\mathrm{H}_{2} \mathrm{O}_{2}\right)\right)$ by photocatalytic titanium dioxide nanobelts to be used by immobilized CPO for in situ $\mathrm{HOCl}$ generation is tested. Secondly, the production of $\mathrm{H}_{2} \mathrm{O}_{2}$ by co-immobilized $\mathrm{GO}_{\mathrm{X}}$ onto MWCNTs in the presence of glucose to be further used by immobilized $\mathrm{CPO}$ for in situ $\mathrm{HOCl}$ generation is examined. Characterization of both conjugate systems as well as their capacity for $\mathrm{HOCl}$ generation is presented in detail. The decontaminant production capability of the CPO-MWCNTs-GOX $\mathrm{Gystem}_{\mathrm{X}}$ shows promise for the next generation of active surface decontamination coatings. A. Campbell, C. Dong, C. Xiang, N. Q. Wu, J. S. Dordick and C. Z. Dinu, "Bionano Engineering Hybrids for the Next Generation of SelfSustainable Decontamination Coatings" Submitted to Process Biochemistry.

This thesis also contains Appendices in which supporting information in regard to the respective chapters is detailed. Also attached are other publications in which I have been a contributing author: (1) C. Dong, A. Campbell, R. Eldawud, G. Perhinschi, Y. Rojansakul and C. Z. Dinu, "Effects of Acid Treatment on Structure, Properties and Biocompatibility of Carbon Nanotubes" Applied Surface Science 2013, 264, 261-268. (2) C. Z. Dinu, I. Borkar, S. Bale, A. Campbell, R. Kane and J. S. Dordick "Perhydrolase-nanotube-paint sporicidal composites stabilized by intramolecular crosslinking” Journal of Molecular Catalysis B: Enzymatic 2012, 75,20-2. 


\section{DEDICATION}

My parents Steve Campbell and Nancy Campbell

My brother Robert Campbell 


\section{ACKNOWLEDGEMENTS}

The process of completing the research and coursework necessary to obtain a Master's degree in Chemical Engineering is a very arduous one and would not be possible without constant support. I owe a debt of gratitude to all of those around me that have made it possible for me to reach this point.

I am indebted to my advisor Prof. Cerasela Dinu for her constant advice and assistance. I would not have even been involved in research if it was not for her guidance and the extra work she has put in on my account has not gone unnoticed. I must thank her for everything that has now become possible in my future career. I also want to thank Prof. Nick Wu whose collaborative efforts have made much of my research a possibility. Without these two esteemed scientists none of this work could have occurred.

I would also like to thank the other members of both Prof. Dinu's and Prof. Wu's lab groups with whom I have worked closely over the years as well as the other staff and faculty of the Chemical Engineering Department at WVU. Having been at WVU for so many years they have all had an impact on my career as a student.

Finally, I have to thank my friends and family who have always supported me in everything I have done. 
TABLE OF CONTENTS

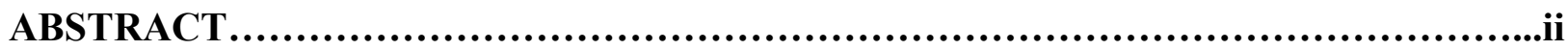

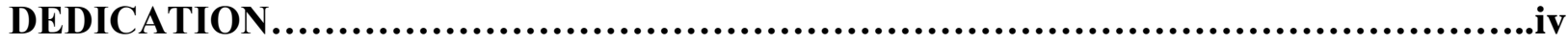

ACKNOWLEDGEMENTS..............................................................v

TABLE OF CONTENTS ............................................................

LIST OF FIGURES......................................................................vii

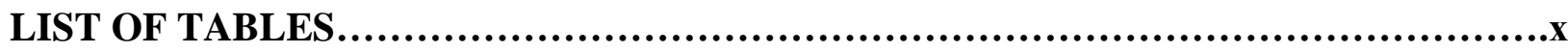

LIST OF SYMBOLS / NOMENCLATURE.............................................xi

CHAPTER 1: ENZYME-BASED TECHNOLOGIES: PERSPECTIVES AND

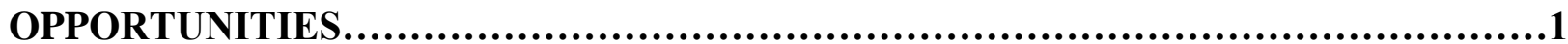

CHAPTER 2: A SYSTEMATIC STUDY OF THE ENZYME-NANOSUPPORT

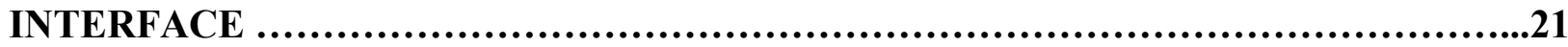

APPENDIX 1.........................................................................46

CHAPTER 3: BIONANO ENGINEERED HYBRIDS FOR MICROBIAL

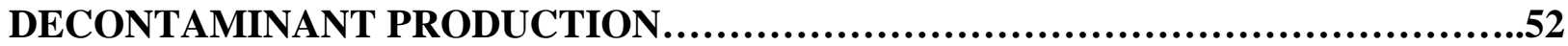

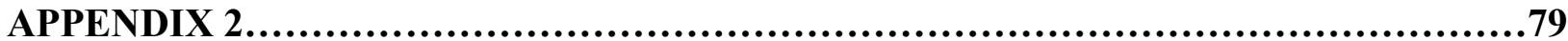




\section{LIST OF FIGURES}

\section{CHAPTER 1: ENZYME-BASED TECHNOLOGIES: PERSPECTIVES AND OPPORTUNITIES}

Figure 1: Schematic diagrams for the applications of enzymes as biological catalysts currently used for industrial-based membrane separation (Figure 1a), biological fuel cell (Figure 1b), as core components in biosensors (Figure 1c), and as active constituents of surfaces with antifouling

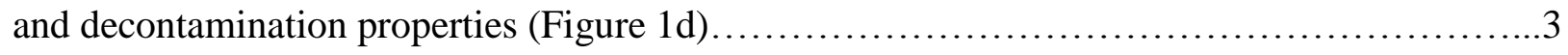

Figure 2: a) Thermal stability of free S54V perhydrolase (AcT; filled diamond), AcT crosslinked with aldehyde dextran (filled squares) and AcT crosslinked with aldehyde dextran and immobilized onto SWCNTs (filled triangles) at $75^{\circ} \mathrm{C}$. b) and c) Deactivation plots following second order deactivation model. d) Sporicidal activity of cross-linked AcT-nanotube based composites: control films (spores in buffer, filled diamond), films containing cross-linked AcTnanotube (filled circles) and control spores in PGD and $\mathrm{H}_{2} \mathrm{O}_{2}$ reaction mixture (filled squares). (Reproduced with permission from reference 23. Copyright 2012 Elsevier)................9

Figure 3: Enzymes are immobilized onto nanosupports and incorporated in composites in a layered technology. When the activity of the enzyme on the outer layer of the coating has decreased below an acceptable level, that layer can be peeled away to expose the lower layer, thereby extending the functional lifetime of the coating.... 


\section{CHAPTER 2: A SYSTEMATIC STUDY OF THE ENZYME-NANOSUPPORT INTERFACE}

Figure 1: FTIR spectra analysis of a) pristine and acid functionalized single-walled carbon nanotubes, b) pristine and acid functionalized multi-walled carbon nanotubes and c) pristine and acid functionalized graphene oxide nanosheets. FTIR spectra confirms the presence of carboxyl functionalizations in the acid functionalized samples....................................... 30

Figure 2: Conceptual image depicting the reaction mechanic of each respective enzyme as well as the immobilization procedure. Surface curvature impacts enzyme structure upon immobilization. 32

Figure 3: Specific retained activity comparison of $\mathrm{SBP}, \mathrm{CPO}$, and $\mathrm{GO}_{\mathrm{X}}$ immobilized onto SWCNTs, MWCNTs and GON via a) physical adsorption, b) covalent binding and c) covalent binding via PEG linker. Enzyme molecular weight as well as nanosupport diameter increase from left to right.

Figure 4: Michaelis-Menten kinetics data of a) SBP immobilized onto SWCNTs (filled squares), MWCNTs (filled circles) and GON (filled triangles) via physical adsorption; b) CPO immobilized onto MWCNTs using physical adsorption (filled squares), covalent binding (filled circles) and covalent binding through a PEG linker (filled triangles); and c) $\mathrm{GO}_{\mathrm{X}}$ immobilized onto MWCNTs using physical adsorption (filled squares), covalent binding (filled circles) and covalent binding through a PEG linker (filled triangles) 


\section{CHAPTER 3: BIONANO ENGINEERED HYBRIDS FOR MICROBIAL DECONTAMINANT PRODUCTION}

Figure 1: a) Functionalization of photocatalyst pristine titanium dioxide results in the formation of carboxyl functionalized nanobelts or $\mathrm{TiO}_{2}$-NBs. b) FTIR spectrum of $\mathrm{TiO}_{2}-\mathrm{NBs}$ reveals the presence of the carboxyl peak at $1731 \mathrm{~cm}^{-1}$, confirming - $\mathrm{COOH}$ functionalization. c) CPO enzyme immobilization onto $\mathrm{TiO}_{2}-\mathrm{NBs}$ with and without the use of a PEG linker. The CPO$\mathrm{TiO}_{2}$-NBs-based conjugates $\mathrm{HOCl}$ generation strategy under UV irradiation.

Figure 2: a) Acids treatment of MWCNTs leads to carboxyl functionalized MWCNTs (MWCNTs-COOH). Functionalization takes place at the defect sites in the MWCNTs structures; the resulting acid treated MWCNTs have hydrophilic residues (represented by the $\mathrm{COOH}$ groups) and hydrophobic walls. The MWCNTs-COOH are used as nanosupports for coimmobilization of $\mathrm{CPO}$ and $\mathrm{GO}_{\mathrm{x}}$. First, $\mathrm{CPO}$ is covalently attached to $\mathrm{COOH}$-functionalized MWCNTs. Subsequently, the CPO-based conjugates are used for the physical attachment of $\mathrm{GO}_{\mathrm{x}} ; \mathrm{GO}_{\mathrm{x}}$ will attach to the hydrophobic walls of the nanotubes to result in $\mathrm{CPO}-\mathrm{GO}_{\mathrm{x}}-\mathrm{MWCNTs}$ conjugates. In the system containing the co-immobilized enzymes and through a chain reaction, $\mathrm{GO}_{\mathrm{X}}$ provides the $\mathrm{H}_{2} \mathrm{O}_{2}$ substrate needed by $\mathrm{CPO}$ for in situ conversion of $\mathrm{Cl}^{-}$into $\mathrm{HOCl}$. b) Raman spectra of pristine (black curve) and carboxyl functionalized (red curve) MWCNTs. The carboxyl functionalized MWCNTs have shifted peaks towards higher relative intensities confirming the $\mathrm{COOH}$ functionalization .65

Figure 3: a) Michaelis-Menten kinetics of enzyme-based MWCNTs conjugates. a) CPO-based conjugates (physically immobilized-open circles; covalently immobilized-filled triangles) kinetics relative to free $\mathrm{CPO}$ in solution (filled squares). b) $\mathrm{GO}_{\mathrm{x}}$-based conjugates (physically immobilized-open circles; covalently immobilized- filled triangles) kinetics relative to free $\mathrm{GO}_{\mathrm{x}}$ in solution (filled squares) .68 


\section{LIST OF TABLES}

\section{CHAPTER 3: BIONANO ENGINEERED HYBRIDS FOR MICROBIAL}

\section{DECONTAMINANT PRODUCTION}

Table 1: Characterization of $\mathrm{CPO}-\mathrm{TiO}_{2}-\mathrm{NBs}$ hybrid system for in situ generation of $\mathrm{HOCl}$....61 Table 2: CPO-MWCNT-GO ${ }_{\mathrm{X}}$ conjugates generate $\mathrm{HOCl}$ in situ. The rate of $\mathrm{HOCl}$ generation is dependent on the enzyme immobilization conditions (i.e., through physical or covalent

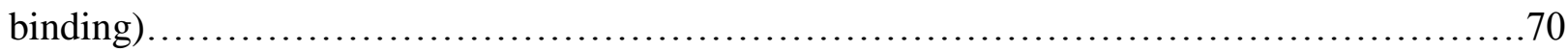




\section{LIST OF SYMBOLS / NOMENCLATURE}

1. SWCNTs: single-walled carbon nanotubes

2. MWNCTs: multi-walled carbon nanotubes

3. GON: graphene oxide nanosheets

4. SBP: soybean peroxidase

5. CPO: chloroperoxidase

6. $\mathrm{GO}_{\mathrm{X}}:$ glucose oxidase

7. EDC: 1-ethyl-3-[3-dimethylaminopropyl] carbodiimide

8. NHS: N-hydroxysuccinimide

9. $\mathrm{HOCl}$ : hypochlorous acid

10. $\mathrm{TiO}_{2}$ : titanium dioxide

11. $\mathrm{TiO}_{2}-\mathrm{NBs}$ : titanium dioxide nanobelts

12. PEG: Amino-dPEG 8 -COOH linker

13. AcT: perhydrolase S54V

14. PGD: propylene glycol diacetate

15. FTIR: Fourier transform infrared spectroscopy

16. SEM: scanning electron microscopy

17. AFM: atomic force microscopy

18. EDX: energy-dispersive X-ray spectroscopy

19. ABTS: 2,2'-Azinobis[3-ethylbenzothiazoline-6-sulfonic acid]

20. MCD: monochlorodimedon

21. MRSA: methicillin-resistant Staphylococcus aureus

22. CMATs: carbon-based materials

23. CAB: citric acid buffer

24. PBS: phosphate buffered saline

25. MES: 2-(N-morpholino)ethanesulfonic acid sodium salt

26. BCA: bicinchonic acid assay 


\title{
CHAPTER 1
}

\section{ENZYME-BASED TECHNOLOGIES: PERSPECTIVES AND OPPORTUNITIES}

\begin{abstract}
Enzymes are biological catalysts that are currently used for biocatalysis, biofuel synthesis and biological fuel cell production, for biosensors, as well as active constituents of surfaces with antifouling and decontamination properties. This review is focused on recent literature covering enzyme-based technologies with emphasis on enzymes as preferred catalysts that provide environmentally friendly, inexpensive and easy to use alternatives to existing decontamination technologies against a wide variety of pathogens, from bacteria to spores.
\end{abstract}

\section{INTRODUCTION}

Enzymes are biological catalysts with high selectivity and specificity ${ }^{1,2}$ that are employed in a wide range of applications from industrial catalysis ${ }^{3-6}$, to biofuel ${ }^{7-10}$ and biofuel cell production $^{11-13}$, from biosensing ${ }^{14-16}$, to pharmaceutical and agrochemical synthesis ${ }^{17-19}$, and in surface active materials with antifouling ${ }^{20-22}$ or decontamination ${ }^{23,24}$ capabilities. Their high specificity and selectivity have enabled enzyme-based industrial processes with high yields and fewer harmful byproducts than those resulting from traditional chemical processes ${ }^{3,}, 4,8$. Furthermore, enzymes operate at much milder conditions of temperature, pressure and $\mathrm{pH}$ than conventional catalysts ${ }^{1,2}$, thereby providing substantial energy and manufacturing costs savings ${ }^{3}$, 25. However, there are a number of practical problems associated with the development of enzyme-based technologies in vitro. For instance, enzyme isolation and purification is laborious and $\operatorname{costly}^{18}$ and most of the isolated enzymes have optimum activity in water-based environments. Further, in such applications ${ }^{26}$ their increased specificity and selectivity could lead to narrow-ranged and focused catalysis, thus enzyme-based systems with short operational lifetimes ${ }^{1,2}$.

Enzyme immobilization is used as a viable alternative to overcome the limitations of enzyme-based applications in vitro and to ensure high enzyme activity retention and high operational stability ${ }^{2,27}$. The choice of immobilization technique is determined by considering both chemical and physical properties of the enzymes and of the support surfaces. As such, 
immobilization has been achieved by entrapping enzymes into polymer matrices ${ }^{28,29}$, LangmuirBlodgett films ${ }^{30,31}$, solid ${ }^{32}$ or liquid- ${ }^{33}$ based membranes, or simply by attachment of enzymes onto solid supports (either by covalent or physical immobilization) ${ }^{16,34,35}$. This review is focused on the current trends in enzyme-based technologies and our own research aimed at developing decontamination platforms based on enzymes and capable of neutralizing bacteria, viruses and spores $^{23,24,36}$. Various enzyme immobilization strategies are discussed and further insights into the next generation of surface decontamination technologies are provided, outlining the studies that are underway to enable these technologies to be self-sustainable (i.e. operate under ambient conditions without external addition of the enzyme substrate).

\section{INDUSTRIAL CATALYSIS}

Biocatalysis ${ }^{25}$ has gained widespread use across several industries including food processing, specialty and commodity chemicals, and in pharmaceuticals production ${ }^{5,17,18}$. For example, in pharmaceutical and chemical industries, enzymes are used to circumvent the often complicated steps required by chemical synthesis and separation in order to generate compounds of high purity, typically chiral, while having a much lower environmental impact ${ }^{3,17,18}$. A hypothetical process is shown in Figure 1a; the image shows a nanoparticle-enzyme-based packing technology developed for large-scale industrial reacting.

The industrial use of enzymes has been influenced by the emerging technologies that allowed recombinant technology or genetic engineering ${ }^{3,17,18}$ to be implemented for the generation of enzymes with improved catalytic properties and selectivity ${ }^{25,37}$, as well as by the development of immobilization and polymer-based crosslinking techniques that allow enhanced enzyme stability $^{1,2,23}$. Specifically, when an enzyme is immobilized onto the surface of a chosen support it can become partially denatured, i.e., the secondary and tertiary structural features of the enzyme can be altered, thus reducing its activity ${ }^{38}$. Furthermore, enzyme-enzyme aggregation can occur at high surface loadings, which can further reduce enzyme activity ${ }^{39}$. Immobilization and crosslinking of enzymes onto nanoscale supports, such as carbon nanotubes, are not only capable of increasing enzyme activity and stability in extreme conditions ${ }^{1,23}$, but could also allow for enzyme retention and thus reusability in several reaction processes. Activies of the enzymes immobilized at the nanoscale support have been found to be influenced by the properties of the support (i.e., surface curvature, surface chemistry, etc.) as well as by the 
immobilization method being used (covalent versus physical) ${ }^{39}$. For example, when Dinu et al. immobilized perhydrolase S54V (AcT) onto single-walled carbon nanotubes (SWCNTs), the immobilization process yielded $\sim 20 \%$ of the specific activity compared to the activity of free enzyme in solution. However, when the enzyme was crosslinked using aldehyde dextran prior to immobilization onto the SWCNTs, $40 \%$ specific activity was retained ${ }^{23}$. These advantages of using enzyme immobilization or enzyme crosslinking might reduce the high cost associated with enzyme production and use ${ }^{18,27}$.

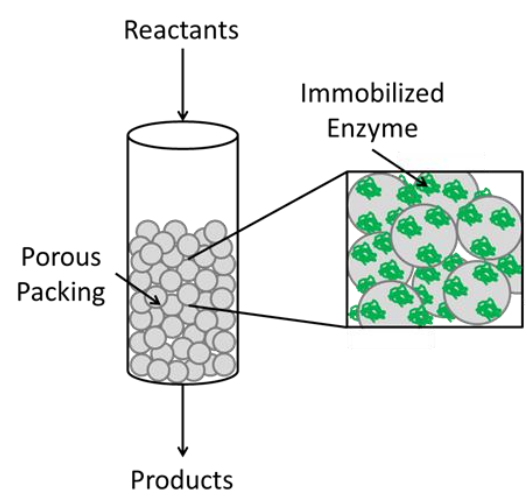

a) Industrial Catalysis

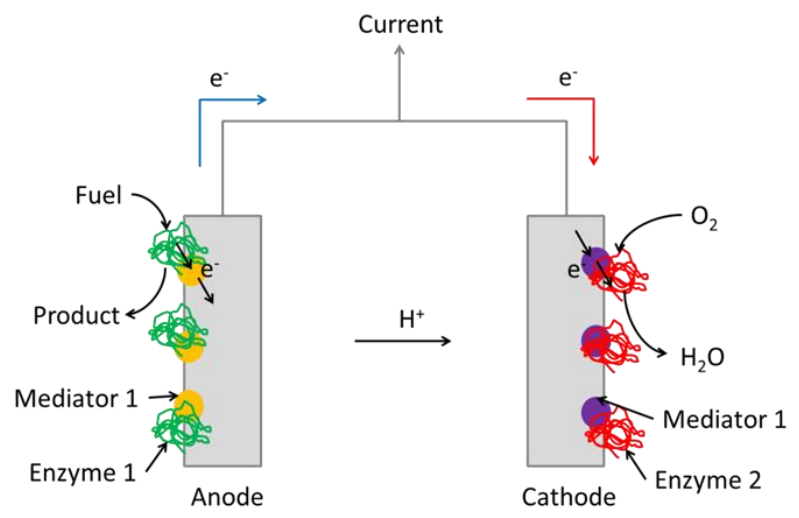

b) Enzymes for Energy

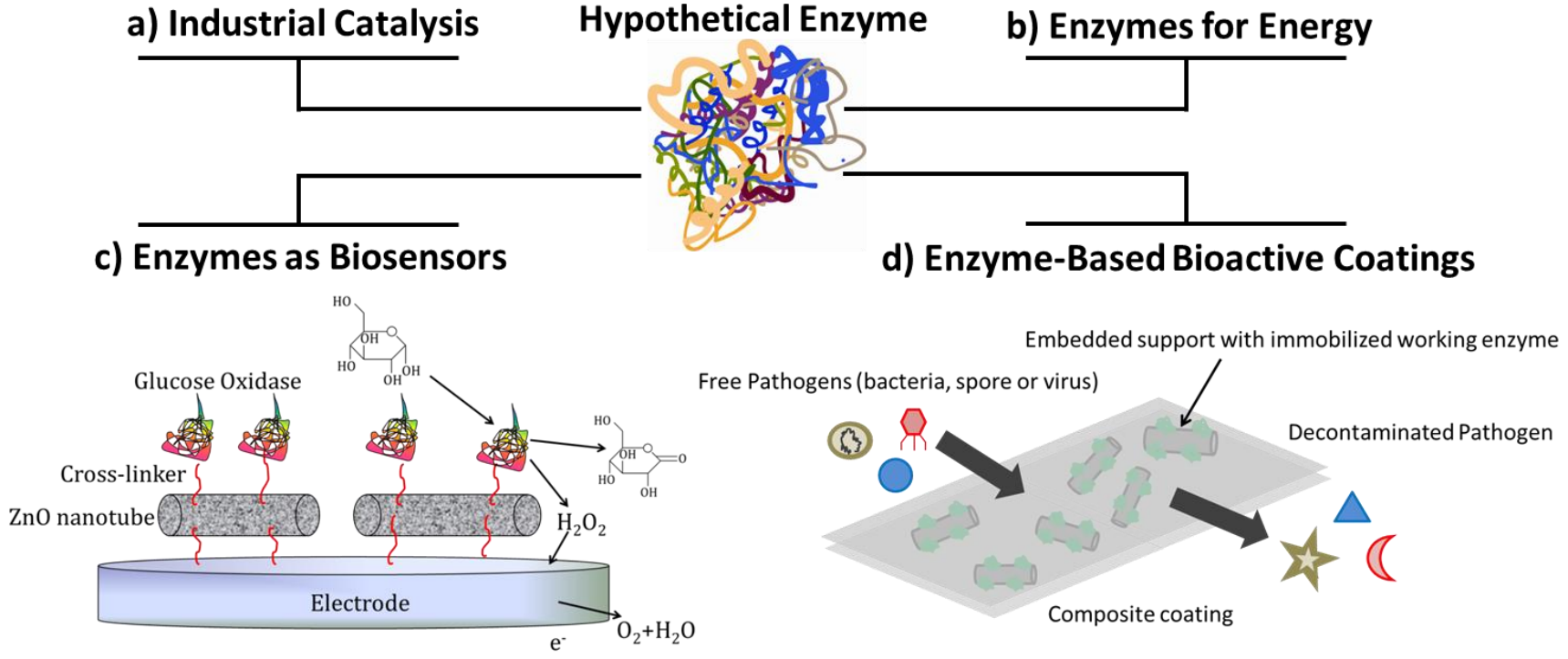

Figure 1: Schematic diagrams for the applications of enzymes as biological catalysts currently used for industrial-based membrane separation (Figure 1a), biological fuel cell (Figure 1b), as core components in biosensors (Figure 1c), and as active constituents of surfaces with antifouling and decontamination properties (Figure 1d). 


\section{ENZYMES FOR ENERGY: BIOFUEL SYNTHESIS AND BIOLOGICAL FUEL CELLS}

Enzymes are at the forefront of several emerging energy technologies that will help to revolutionize energy production on both the macro- and micro-scales. Energy-based applications of enzymes include: biofuel synthesis and enzyme biofuel cell production.

With the costs of fossil fuels on the rise and a greater push for more environmentally friendly energy sources, biofuels represent a valuable alternative energy source, with enzymatic processing being a critical component of the process ${ }^{8,40}$. Generally, biofuels are produced via the biochemical conversion (e.g., hydrolysis, esterification or transesterification) of renewable biomass, either chemically or enzymatically ${ }^{7}{ }^{10}$. Biofuels such as bioethanol and biodiesel are a classification of fuels derived from biomass conversion. In the United States, bioethanol manufactured from cornstarch was widely used in recent years ${ }^{41}$. Biodiesel is produced from a variety of sources through the transesterification of alkyl esters from feedstock and not only is more environmentally-friendly but also can be used with a higher efficiency than traditional gasoline ${ }^{41}$. The selectivity and biocompatibility of enzymes lead to a more efficient process with fewer unwanted byproducts than traditional chemical processing ${ }^{8}$. The large loading requirements and inherent cost of enzymes have reduced the enthusiasm for industrial scale use of enzymes for biofuel production ${ }^{8}$. However, the economic viability of enzymatic processes can be improved through enzyme immobilization onto solid supports to allow for large-scale production ${ }^{27}$ and reusability ${ }^{42}$.

Biological fuel cells transform the chemical energy of organic compounds, such as glucose or ethanol, into electricity by using enzymes as the catalyst ${ }^{11,12,43}$. Figure $1 \mathrm{~b}$ shows a schematic diagram of an enzyme-based fuel cell. The biofuel reaction is catalyzed by two different enzymes; the oxidation of the enzyme at the anode interface transfers the electrons to the cathode and onto a second enzyme to lead to electric current production. Enzyme functionality and specificity allow the construction of the fuel cells without a membrane separating the anode and cathode $^{12,43}$. Due to this feature, enzyme-based fuel cells can be easily miniaturized to allow incorporation into implantable biomedical devices such as artificial organs, micro-pumps, microvalves, pacemakers and sensors ${ }^{13,43}$ further decreasing the risk of cytotoxicity associated with the implants ${ }^{13}$. 


\section{ENZYMES AS BIOSENSORS}

Enzyme-based biosensors can be used for recognition and quantification of various analytes from sugar ${ }^{44-46}$ to hydrogen peroxide ${ }^{47}$, and from superoxide anions ${ }^{48}$, to proteins ${ }^{49}$. Enzymebased biosensors are formed by immobilizing enzymes onto a wide range of transducers, including electrodes ${ }^{50}$; the immobilized enzymes create an "open-gate-based electron communication window" with the electrode surface ${ }^{51,52}$. The general physical and chemical properties of the materials used in the construction of biosensors, as well as the working conditions being employed, play a significant role in the performance and the detection capability of the biosensor ${ }^{53}$. For developing the next generation of viable biosensors with increased flexibility, accuracy, specificity and optimal performance, the proper support materials and enzyme immobilization conditions need to be carefully considered. The examples included below provide a comprehensive guide into current enzyme-based biosensors used in several laboratory and industrial settings.

Glucose detection is of great importance in various fields such as the food industry, quality monitoring processes, and in clinical settings for diabetes diagnosis and therapeutic maintenance ${ }^{54}$. Due to their high surface area-volume ratio, as well as their low toxicity and ease of fabrication, metal oxide-based and carbon-based nanomaterials are considered excellent candidates for immobilization of glucose oxidase to lead to the next generation of glucose-based biosensors (Figure 1c) ${ }^{55}$. Zinc oxide nanotubes were recently used in biosensor fabrication that allowed linear detection of glucose in only $3 \mathrm{~s}$, with a limit of detection between $50 \mu \mathrm{M}$ to 12 $\mathrm{mM}^{56}$; in this example the reaction is catalyzed by the glucose oxidase enzyme which transfers electrons to the support conductive material. Similarly, glucose oxidase-tetragonal pyramidshaped zinc oxide nanostructure biosensors allowed detection in a range of $50 \mu \mathrm{M}$ to $8.2 \mathrm{mM}^{57}$. In other settings, glucose oxidase was immobilized onto platinum multi-walled carbon nanotubealumina-coated silica nanocomposites to form biosensors that displayed wide linear detection up to $10.5 \mathrm{mM}$ and response time of less than $5 \mathrm{~s}^{58}$. Lastly, bionanocomposites comprising glucose oxidase-platinum-functional graphene-chitosan complexes were used to achieve a detection limit of $0.6 \mu \mathrm{M}^{59}$. For clinical application, a multi-layer cadmium telluride quantum dot-glucose oxidase conjugate biosensor was developed to detect glucose concentrations in serum; such a biosensor allowed glucose detection with minimal pretreatment of the sample and with increased accuracy $^{60}$. 
Lactose is a metabolic byproduct regulated by the food industry ${ }^{61,62}$. Novel, rapid, simple and inexpensive biosensors that allow precise detection of lactose were constructed by integrating 3-mercapto propionic acid functionalized gold electrodes and beta-galactosidaseglucose oxidase-peroxidase-mediator tetrathiafulvalene combined membranes ${ }^{63}$. Such biosensors exhibited a linear detection range of $1.5 \mu \mathrm{M}$ to $120 \mu \mathrm{M}$, with a detection limit of $0.46 \mu \mathrm{M}$. Furthermore, such biosensors had a working lifetime of nearly 1 month.

Hydrogen peroxide is the byproduct of several biochemical oxidation processes, as well as an essential mediator in clinical, pharmaceutical and food industries as well as in the environment ${ }^{64}$. Fast, accurate and reliable detection of hydrogen peroxide was achieved using horseradish or soybean peroxidase enzyme-based systems. For instance, horseradish peroxidase was immobilized onto gold functionalized titanium dioxide nanotubes ${ }^{65}$ or onto chitosan-based nanocomposites $^{66}$ to allow the construction of biosensors with a hydrogen peroxide detection range of $5 \mu \mathrm{M}$ to $400 \mu \mathrm{M}$ (detection limit of $2 \mu \mathrm{M}$ ) and of $0.6 \mu \mathrm{M}$ to $160 \mu \mathrm{M}$ (detection limit of $0.15 \mu \mathrm{M})$, respectively. Similarly, soybean peroxidase-based biosensors were formed by immobilization of the enzyme onto single-walled carbon nanohorns and showed linear detection ranging from $20 \mu \mathrm{M}$ to $1.2 \mathrm{mM}$ (detection limit of $0.5 \mu \mathrm{M}$ ) ${ }^{67}$.

Biological analytes ranging from superoxide anions to proteins have also been detected using enzyme-based biosensors. The superoxide anion is mostly regarded as toxic, leading to cellular death and mutagenesis ${ }^{68}$. Recently, a novel, disposable superoxide anion biosensor based on the enzyme superoxide dismutase was fabricated ${ }^{48}$. Such a biosensor was able to detect superoxide anions in a range from $0.08 \mu \mathrm{M}$ to $0.64 \mu \mathrm{M}$; furthermore, this biosensor showed increased sensitivity, accuracy and long term stability. Also, a horseradish peroxidase-gold nanoparticlescarbon nanotube hybrid biosensor proved to have excellent ability to detect human $\operatorname{IgG}$ protein for advancing immuno-analysis assays ${ }^{69}$.

Enzyme amperometric biosensors have also been developed and employed for the detection, monitoring and reporting of biochemical analytes related to a wide range of pathologies ranging from diabetes to trauma-associated hemorrhage ${ }^{53}$. Implantable enzyme amperometric biosensors must recognize, transmute and generate physicochemical signals that are proportional to the chemical potential (concentration) of the analytes they are intended to be measured. Kotanen et al. have summarized the properties of such biosensors, as well as the conditions required to ensure enzyme biotransducer performance such as the stability, substrate interference, or 
mediator selection. The failures associated with enzyme-based biosensors are mainly due to the degradation of the immobilized enzyme or its denaturation at the interface by unfolding which could lead to loss of biorecognition and thus loss of signal transduction ${ }^{51-53}$.

\section{ENZYME-BASED BIOACTIVE COATINGS}

Enzymes can be used to provide biological function to non-biological materials, thus leading to a "bioactive" material or surface ${ }^{70}$. In many such applications, enzymes are incorporated into paint or polymer-based coatings and subsequently applied to a desired surface $22,24,71$. Two of the main areas in which this type of technology is being employed are in the development of antifouling surfaces ${ }^{20,21}$ and surfaces with active decontamination capabilities ${ }^{23,36}$. Figure 1d illustrates the general principle of enzyme-based coatings; enzymes are immobilized onto nanosupports and upon entrapment in composite-based materials they can generate reactive species to prevent biofilm formation or to allow decontamination.

\section{ENZYME-BASED ANTIFOULING COATINGS}

The main aim of antifouling coatings is to prevent the attachment and growth of living organisms (referred to as a biofilm) onto a surface ${ }^{22}$. This functionality is vital in many different applications including biomedical implants ${ }^{72}$, biosensors ${ }^{73}$ and several types of equipment used in industrial and marine settings ${ }^{74,75}$. There are two major steps in biofilm formation: the initial adhesion of the fouling species, and the proliferation of that species ${ }^{22}$. To combat adhesion or reduce adhesion strength ${ }^{76}$, "non-sticky" coatings have been developed ${ }^{77}$. To deter proliferation, enzyme-based coatings that generate reactive species to prevent biofilm formation have been developed $^{22}$. Such technologies offer viable alternatives to traditional antifouling coatings that rely on the use of broadly cytotoxic compounds ${ }^{78,79}$, and further provide safer and more environmentally friendly substitutes.

\section{ENZYME-BASED DECONTAMINATION COATINGS}

Enzyme-based decontamination platforms have been proposed as viable alternatives to currently available decontamination methods that use harsh chemicals and pose environmental and logistical burdens ${ }^{80-82}$. Our groups have pioneered research into enzyme-nanomaterial-based coatings to be used as decontamination platforms that exhibit bactericidal, virucidal and 
sporicidal activities $^{23,24,36,83}$. For instance, we have shown that upon enzyme immobilization onto carbon-based nanomaterials, including carbon nanotubes, enzyme S54V perhydrolase (AcT) stability is increased under adverse conditions such as high temperature (up to $75^{\circ} \mathrm{C}$ ) as well as over long periods of time and room temperature storage conditions ${ }^{23,38,84}$ (Figure 2a,b,c). Also, the conjugates thus formed can further be incorporated into polymer or paint-based coatings without undesired leaching of the enzyme ${ }^{23,71}$.

The decontamination capabilities of such coatings were tested against various pathogens. Peracetic acid generated by carbon nanotube-immobilized S54V perhydrolase in a latex-based coating was found to be able to decontaminate $>99 \%$ of $10^{6} \mathrm{CFU} / \mathrm{mL} \mathrm{B}$. cereus spores within $1 \mathrm{~h}$ (Figure 2d), $4 \times 10^{7} \mathrm{PFU} / \mathrm{mL}$ influenza virus in $15 \mathrm{~min}$, and $10^{6} \mathrm{CFU} / \mathrm{mL}$ E. coli in only $5 \mathrm{~min}$, upon addition of the substrates propylene glycol diacetate and hydrogen peroxide ${ }^{23,83}$. With a sustainable substrate source, such coatings can be used in the future as a passive decontamination measure to combat aerosolized anthrax. Additionally, Pangule et al. showed the antimicrobial capabilities of a lysostaphin-based coating. When such coatings were tested against $10^{6} \mathrm{CFU} / \mathrm{mL}$ of methicillin-resistant Staphylococcus aureus (MRSA), >99\% killing capability was achieved in only $2 \mathrm{~h}^{36}$. Borkar et al. tested the bactericidal and sporicidal capabilities of two other enzymes incorporated into paint-based coatings, namely laccase and chloroperoxidase. Hypochlorous acid produced by chloroperoxidase in the presence of hydrogen peroxide and $\mathrm{Cl}^{-}$ions was found to be capable of killing $>99 \%$ of $10^{6} \mathrm{CFU} / \mathrm{mL}$ S. aureus and E. coli after $30 \mathrm{~min}$. Immobilized laccase also showed bactericidal activity in the presence of several mediators with $>99 \%$ killing achieved in $30 \mathrm{~min}$ for S. aureus and in $60 \mathrm{~min}$ for E. coli. The sporicidal capabilities of laccase were also demonstrated with $>99 \%$ killing of $10^{4} \mathrm{CFU} / \mathrm{mL}$ B. cereus and B. anthracis spores in $2 \mathrm{~h}^{24}$. All of these results show the enormous potential of enzyme-based systems for active surface decontamination in multiple situations including hospital and military scenarios ${ }^{23,24,36,83}$. 
a)

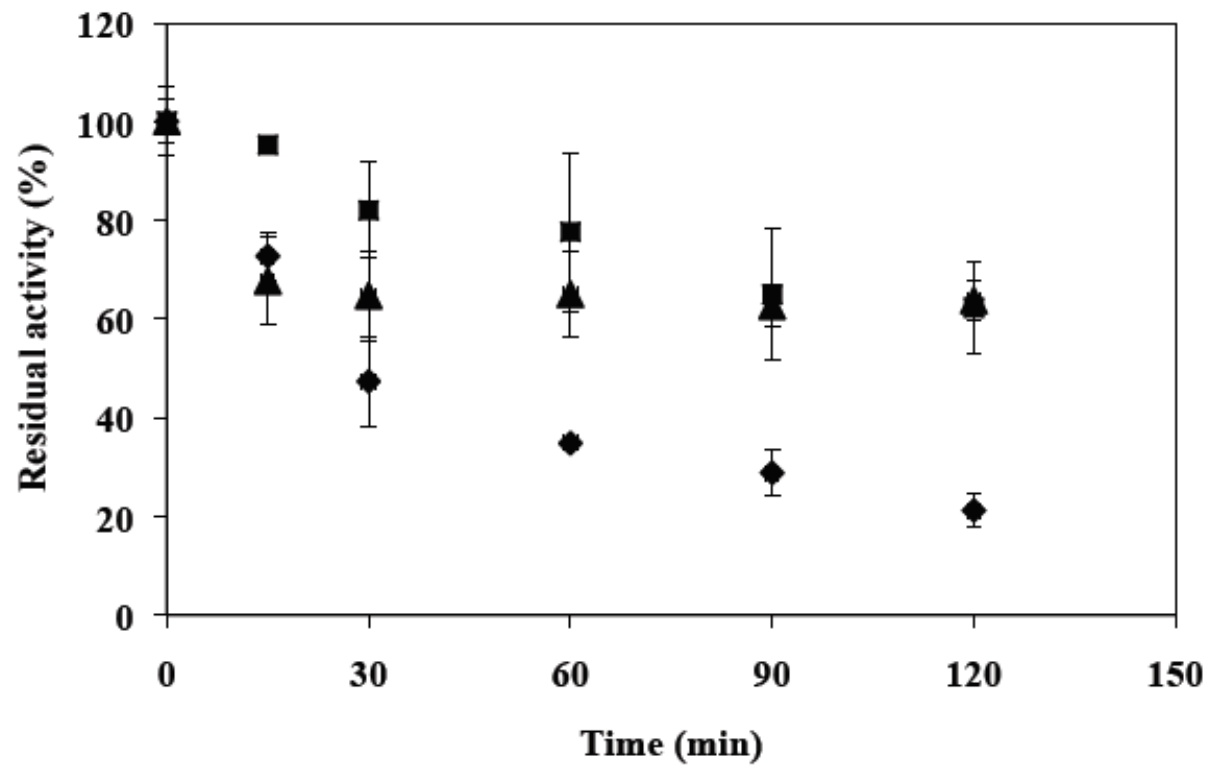

b)

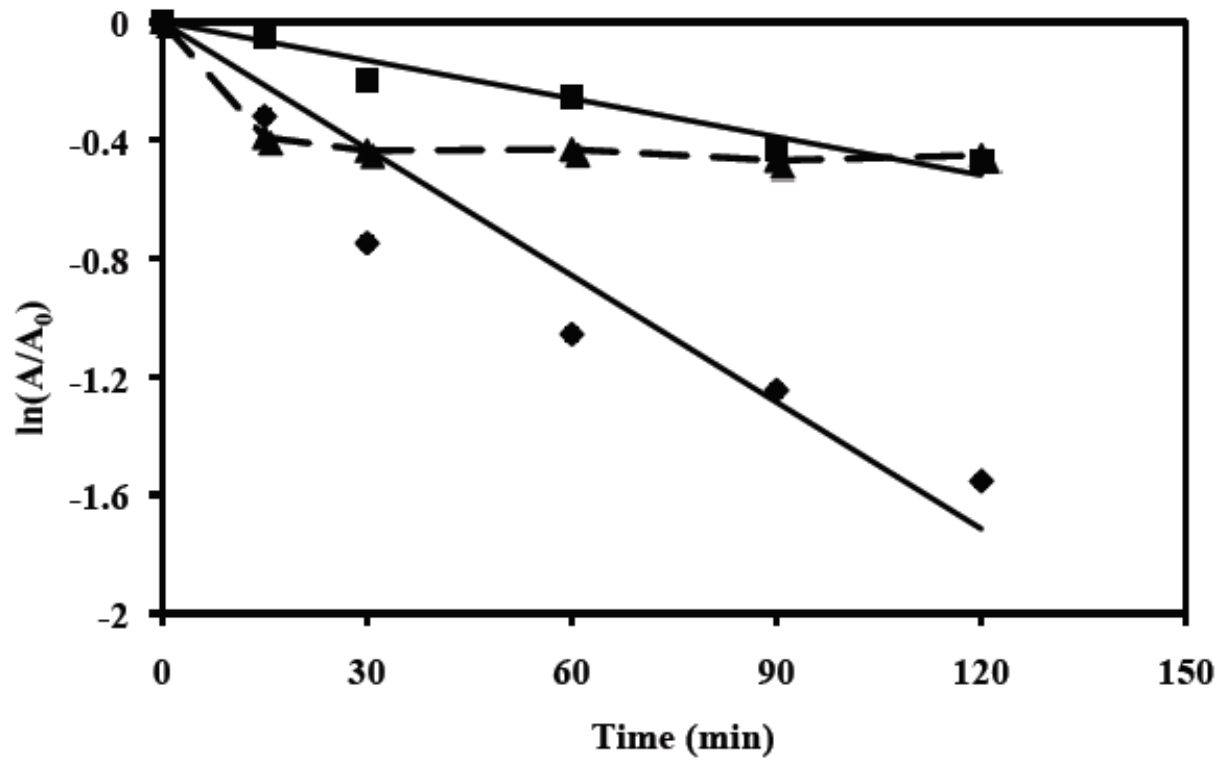



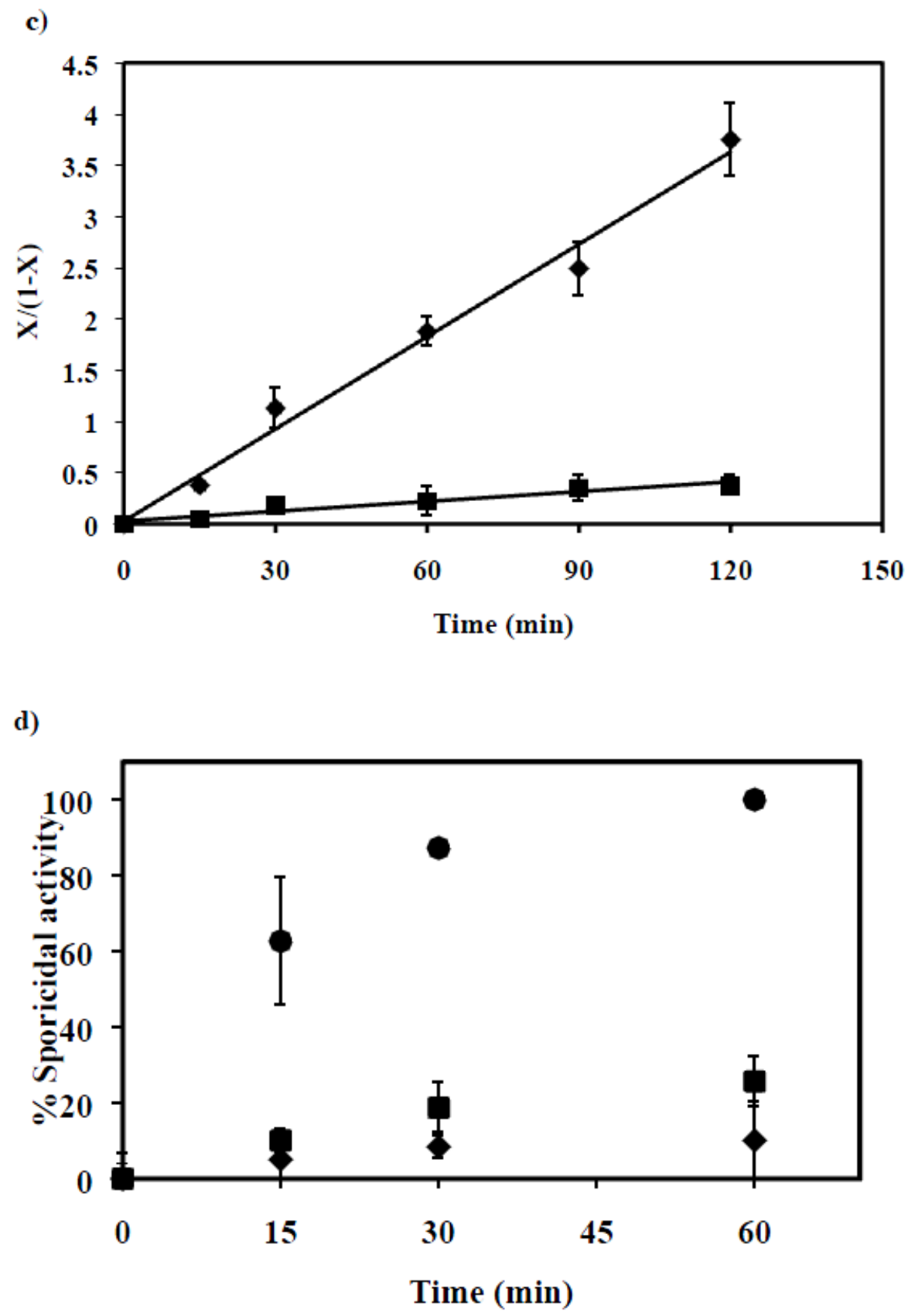

Figure 2: a) Thermal stability of free S54 perhydrolase (AcT; filled diamond), AcT crosslinked with aldehyde dextran (filled squares) and AcT crosslinked with aldehyde dextran and immobilized onto SWCNTs (filled triangles) at $75^{\circ} \mathrm{C}$. b) and c) Deactivation plots following second order deactivation model. d) Sporicidal activity of cross-linked AcT-nanotube based composites: control films (spores in buffer, filled diamond), films containing cross-linked AcTnanotube (filled circles) and control spores in propylene glycol diacetate (PGD) and $\mathrm{H}_{2} \mathrm{O}_{2}$ reaction mixture (filled squares). (Reproduced with permission from reference 23. Copyright 2012 Elsevier). 


\section{CONCLUSIONS AND FUTURE DIRECTIONS}

Recent advances in bioinformatics and molecular biology techniques have allowed production of enzymes with high activity, controlled specificity, and high catalytic power. Simultaneously, recent developments in immobilization of enzymes onto several nanoscale supports that have tailored properties controlled by the user, allowed the development of the next generation of enzyme-based applications as illustrated in this review. Growth in these areas will surely continue. For example, our groups continue to focus on enzyme-based decontamination strategies that will function without addition of external reagents, i.e., either the substrate or the enzyme mediator. Such enzyme-based decontamination strategies aim to be functional by simply relying on ambient conditions and will initiate in situ enzymatic generation of decontaminants; such systems are further defined as being self-sustainable. To achieve this goal, we are currently investigating a working strategy that allows immobilization of chloroperoxidase enzyme onto titanium dioxide nanosupports. Titanium dioxide is a widely studied photocatalyst that produces hydrogen peroxide from water when excited under UV-light. Hydrogen peroxide generated at the photocatalyst nanointerface could serve as the substrate for enzymatic in situ hypochlorous acid generation; hypochlorous acid is a much stronger decontaminant than $\mathrm{H}_{2} \mathrm{O}_{2}{ }^{85,}{ }^{86}$ and thus has a broader activity range against both bacterial and sporicidal contaminants ${ }^{24}$. Such strategy may be used in the development of the next generation of self-sustainable decontamination systems upon incorporation into a coating.

A major problem arising from the use of enzymes in a surface coating is enzyme deactivation over time ${ }^{25}$. We envision the development of layered-based technologies that would allow usercontrolled coating performance of such enzyme-based decontamination strategies (Figure 3). Specifically, in a layered system, when the activity of the enzyme on the outer layer of the coating has decreased below an acceptable level, that layer can be peeled away to expose the lower layer, thereby extending the functional lifetime of the coating. Ultimately, the potential for biotechnological application will be whether such systems can be durable and operate over a wide variety of conditions while having increased operational stability, shelf-life and being environmentally and user friendly. 


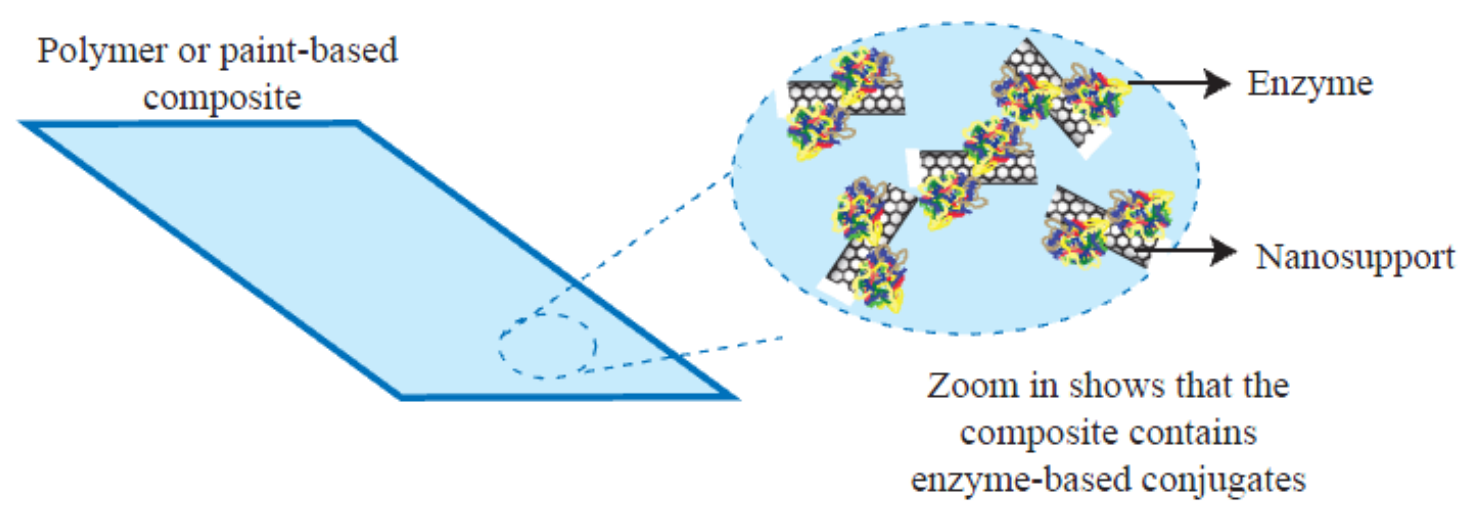

Reactive species

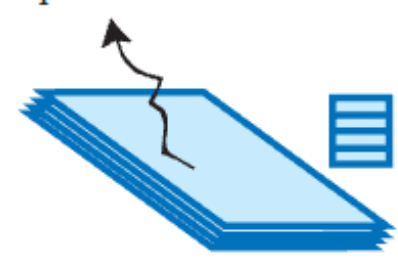

Layer-by-layer composite
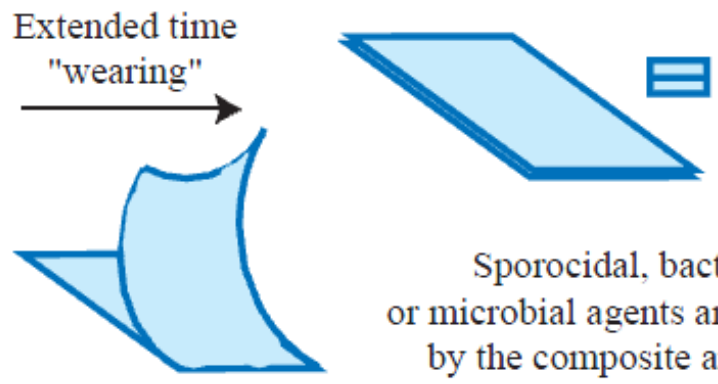

Sporocidal, bacterial or microbial agents are released by the composite and used for decontamination

Figure 3: Enzymes are immobilized onto nanosupports and incorporated in composites in a layered technology. When the activity of the enzyme on the outer layer of the coating has decreased below an acceptable level, that layer can be peeled away to expose the lower layer, thereby extending the functional lifetime of the coating. 


\section{REFERENCES}

1. Mateo, C.; Palomo, J. M.; Fernandez-Lorente, G.; Guisan, J. M.; Fernandez-Lafuente, R., Improvement of enzyme activity, stability and selectivity via immobilization techniques. Enzyme Microb Tech 2007, 40, (6), 1451-1463.

2. Garcia-Galan, C.; Berenguer-Murcia, A.; Fernandez-Lafuente, R.; Rodrigues, R. C., Potential of Different Enzyme Immobilization Strategies to Improve Enzyme Performance. Adv Synth Catal 2011, 353, (16), 2885-2904.

3. Schmid, A.; Dordick, J. S.; Hauer, B.; Kiener, A.; Wubbolts, M.; Witholt, B., Industrial biocatalysis today and tomorrow. Nature 2001, 409, (6817), 258-268.

4. Kuddus, M.; Ramteke, P. W., Recent developments in production and biotechnological applications of cold-active microbial proteases. Crit Rev Microbiol 2012, 38, (4), 330-338.

5. Falch, E. A., Industrial Enzymes - Developments in Production and Application. Biotechnol Adv 1991, 9, (4), 643-658.

6. Wong, C. M.; Wong, K. H.; Chen, X. D., Glucose oxidase: natural occurrence, function, properties and industrial applications. Appl Microbiol Biot 2008, 78, (6), 927-938.

7. Mata, T. M.; Sousa, I. R. B. G.; Vieira, S. S.; Caetano, N. S., Biodiesel Production from Corn Oil via Enzymatic Catalysis with Ethanol. Energ Fuel 2012, 26, (5), 3034-3041.

8. Zhang, Z. S.; Donaldson, A. A.; Ma, X. X., Advancements and future directions in enzyme technology for biomass conversion. Biotechnol Adv 2012, 30, (4), 913-919.

9. Wang, L.; Templer, R.; Murphy, R. J., High-solids loading enzymatic hydrolysis of waste papers for biofuel production. Appl Energ 2012, 99, 23-31.

10. Menon, V.; Rao, M., Trends in bioconversion of lignocellulose: Biofuels, platform chemicals \& biorefinery concept. Prog Energ Combust 2012, 38, (4), 522-550.

11. Zhang, J. M.; Zhu, Y. H.; Chen, C.; Yang, X. L.; Li, C. Z., Carbon nanotubes coated with platinum nanoparticles as anode of biofuel cell. Particuology 2012, 10, (4), 450-455.

12. Stolarczyk, K.; Lyp, D.; Zelechowska, K.; Biernat, J. F.; Rogalski, J.; Bilewicz, R., Arylated carbon nanotubes for biobatteries and biofuel cells. Electrochim Acta 2012, 79, 74-81.

13. Ammam, M.; Fransaer, J., Combination of laccase and catalase in construction of H2O2-O-2 based biocathode for applications in glucose biofuel cells. Biosensors \& bioelectronics 2013, 39, (1), 274-281. 
14. Tu, X. M.; Zhao, Y. J.; Luo, S. L.; Luo, X. B.; Feng, L., Direct electrochemical sensing of glucose using glucose oxidase immobilized on functionalized carbon nanotubes via a novel metal chelate-based affinity method. Microchim Acta 2012, 177, (1-2), 159-166.

15. Zargoosh, K.; Chaichi, M. J.; Shamsipur, M.; Hossienkhani, S.; Asghari, S.; Qandalee, M., Highly sensitive glucose biosensor based on the effective immobilization of glucose oxidase/carbon-nanotube and gold nanoparticle in nafion film and peroxyoxalate chemiluminescence reaction of a new fluorophore. Talanta 2012, 93, 37-43.

16. Sassolas, A.; Blum, L. J.; Leca-Bouvier, B. D., Immobilization strategies to develop enzymatic biosensors. Biotechnol Adv 2012, 30, (3), 489-511.

17. Zaks, A., Industrial biocatalysis. Curr Opin Chem Biol 2001, 5, (2), 130-136.

18. Pollard, D. J.; Woodley, J. M., Biocatalysis for pharmaceutical intermediates: the future is now. Trends Biotechnol 2007, 25, (2), 66-73.

19. Adamczak, M.; Krishna, S. H., Strategies for improving enzymes for efficient biocatalysis. Food Technol Biotech 2004, 42, (4), 251-264.

20. Banerjee, I.; Pangule, R. C.; Kane, R. S., Antifouling Coatings: Recent Developments in the Design of Surfaces That Prevent Fouling by Proteins, Bacteria, and Marine Organisms. Adv Mater 2011, 23, (6), 690-718.

21. Magin, C. M.; Cooper, S. P.; Brennan, A. B., Non-toxic antifouling strategies. Mater Today 2010, 13, (4), 36-44.

22. Kristensen, J. B.; Meyer, R. L.; Laursen, B. S.; Shipovskov, S.; Besenbacher, F.; Poulsen, C. H., Antifouling enzymes and the biochemistry of marine settlement. Biotechnol Adv 2008, 26, (5), 471-481.

23. Dinu, C. Z.; Borkar, I. V.; Bale, S. S.; Campbell, A. S.; Kane, R. S.; Dordick, J. S., Perhydrolase-nanotube-paint sporicidal composites stabilized by intramolecular crosslinking. $J$ Mol Catal B-Enzym 2012, 75, 20-26.

24. Grover, N.; Borkar, I. V.; Dinu, C. Z.; Kane, R. S.; Dordick, J. S., Laccase- and chloroperoxidase-nanotube paint composites with bactericidal and sporicidal activity. Enzyme Microb Tech 2012, 50, (6-7), 271-279.

25. Bornscheuer, U. T.; Huisman, G. W.; Kazlauskas, R. J.; Lutz, S.; Moore, J. C.; Robins, K., Engineering the third wave of biocatalysis. Nature 2012, 485, (7397), 185-194. 
26. Karyakin, A. A.; Kotel'nikova, E. A.; Lukachova, L. V.; Karyakina, E. E.; Wang, J., Optimal environment for glucose oxidase in perfluorosulfonated ionomer membranes: Improvement of first-generation biosensors. Anal Chem 2002, 74, (7), 1597-1603.

27. Sheldon, R. A., Enzyme immobilization: The quest for optimum performance. Adv Synth Catal 2007, 349, (8-9), 1289-1307.

28. Shi, J.; Claussen, J. C.; McLamore, E. S.; ul Haque, A.; Jaroch, D.; Diggs, A. R.; CalvoMarzal, P.; Rickus, J. L.; Porterfield, D. M., A comparative study of enzyme immobilization strategies for multi-walled carbon nanotube glucose biosensors. Nanotechnology 2011, 22, (35).

29. Rubio-Retama, J.; Lopez-Cabarcos, E.; Lopez-Ruiz, B., High stability amperometric biosensor based on enzyme entrapment in microgels. Talanta 2005, 68, (1), 99-107.

30. Pastorino, L.; Nicolini, C., Langmuir-Blodgett films of lipase for biocatalysis. Mat Sci Eng C-Bio S 2002, 22, (2), 419-422.

31. Zanon, N. C. M.; Oliveira, O. N.; Caseli, L., Immbolization of uricase enzyme in Langmuir and Langmuir-Blodgett films of fatty acids: Possible use as a uric acid sensor. J Colloid Interf Sci 2012, 373, 69-74.

32. Pan, C. W.; Chou, J. C.; Sun, T. P.; Hsiung, S. K., Solid-state urea biosensor based on the differential method. Ieee Sens J 2006, 6, (2), 269-275.

33. Yabuki, S.; Hirata, Y.; Sato, Y.; Iijima, S., Preparation of a Cellulose-based Enzyme Membrane Using Ionic Liquid to Lengthen the Duration of Enzyme Stability. Anal Sci 2012, 28, (4), 373-377.

34. Tsai, T. W.; Heckert, G.; Neves, L. F.; Tan, Y. Q.; Kao, D. Y.; Harrison, R. G.; Resasco, D. E.; Schmidtke, D. W., Adsorption of Glucose Oxidase onto Single-Walled Carbon Nanotubes and Its Application in Layer-By-Layer Biosensors. Anal Chem 2009, 81, (19), 7917-7925.

35. Hirsh, S. L.; Bilek, M. M. M.; Nosworthy, N. J.; Kondyurin, A.; dos Remedios, C. G.; McKenzie, D. R., A Comparison of Covalent Immobilization and Physical Adsorption of a Cellulase Enzyme Mixture. Langmuir 2010, 26, (17), 14380-14388.

36. Pangule, R. C.; Brooks, S. J.; Dinu, C. Z.; Bale, S. S.; Salmon, S. L.; Zhu, G. Y.; Metzger, D. W.; Kane, R. S.; Dordick, J. S., Antistaphylococcal Nanocomposite Films Based on EnzymeNanotube Conjugates. Acs Nano 2010, 4, (7), 3993-4000.

37. Jochens, H.; Bornscheuer, U. T., Natural Diversity to Guide Focused Directed Evolution. Chembiochem 2010, 11, (13), 1861-1866. 
38. Asuri, P.; Bale, S. S.; Pangule, R. C.; Shah, D. A.; Kane, R. S.; Dordick, J. S., Structure, function, and stability of enzymes covalently attached to single-walled carbon nanotubes. Langmuir 2007, 23, (24), 12318-12321.

39. Asuri, P.; Bale, S. S.; Karajanagi, S. S.; Kane, R. S., The protein-nanomaterial interface. Curr Opin Biotech 2006, 17, (6), 562-568.

40. Hahn-Hagerdal, B.; Galbe, M.; Gorwa-Grauslund, M. F.; Liden, G.; Zacchi, G., Bio-ethanol the fuel of tomorrow from the residues of today. Trends Biotechnol 2006, 24, (12), 549-556.

41. Solomon, B. D., Biofuels and sustainability. Ecological Economics Reviews 2010, 1185, 119134.

42. Xie, T.; Wang, A. M.; Huang, L. F.; Li, H. F.; Chen, Z. M.; Wang, Q. Y.; Yin, X. P., Recent advance in the support and technology used in enzyme immobilization. Afr J Biotechnol 2009, 8, (19), 4724-4733.

43. Stolarczyk, K.; Sepelowska, M.; Lyp, D.; Zelechowska, K.; Biernat, J. F.; Rogalski, J.; Farmer, K. D.; Roberts, K. N.; Bilewicz, R., Hybrid biobattery based on arylated carbon nanotubes and laccase. Bioelectrochemistry 2012, 87, 154-163.

44. Yang, C. Y.; Zhang, Z. J.; Shi, Z. L.; Xue, P.; Chang, P. P.; Yan, R. F., Application of a novel co-enzyme reactor in chemiluminescence flow-through biosensor for determination of lactose. Talanta 2010, 82, (1), 319-324.

45. Manesh, K. M.; Kim, H. T.; Santhosh, P.; Gopalan, A. I.; Lee, K. P., A novel glucose biosensor based on immobilization of glucose oxidase into multiwall carbon nanotubespolyelectrolyte-loaded electrospun nanofibrous membrane. Biosensors \& bioelectronics 2008, 23, (6), 771-779.

46. Rakhi, R. B.; Sethupathi, K.; Ramaprabhu, S., A Glucose Biosensor Based on Deposition of Glucose Oxidase onto Crystalline Gold Nanoparticle Modified Carbon Nanotube Electrode. $J$ Phys Chem B 2009, 113, (10), 3190-3194.

47. Yin, H. S.; Ai, S. Y.; Shi, W. J.; Zhu, L. S., A novel hydrogen peroxide biosensor based on horseradish peroxidase immobilized on gold nanoparticles-silk fibroin modified glassy carbon electrode and direct electrochemistry of horseradish peroxidase. Sensor Actuat B-Chem 2009, 137, (2), 747-753. 
48. Wang, J.; Rennie, K. L.; Gu, W.; Li, H.; Yu, Z.; Lin, X., Independent associations of bodysize adjusted fat mass and fat-free mass with the metabolic syndrome in Chinese. Ann Hum Biol 2009, 36, (1), 110-21.

49. Cui, R. J.; Huang, H. P.; Yin, Z. Z.; Gao, D.; Zhu, J. J., Horseradish peroxidasefunctionalized gold nanoparticle label for amplified immunoanalysis based on gold nanoparticles/carbon nanotubes hybrids modified biosensor. Biosensors \& bioelectronics 2008, 23, (11), 1666-1673.

50. Cao, Z. J.; Jiang, X. Q.; Xie, Q. J.; Yao, S. Z., A third-generation hydrogen peroxide biosensor based on horseradish peroxidase immobilized in a tetrathiafulvalenetetracyanoquinodimethane/multiwalled carbon nanotubes film. Biosensors \& bioelectronics 2008, 24, (2), 222-227.

51. Carrara, S.; Ghoreishizadeh, S.; Olivo, J.; Taurino, I.; Baj-Rossi, C.; Cavallini, A.; Op de Beeck, M.; Dehollain, C.; Burleson, W.; Moussy, F. G.; Guiseppi-Elie, A.; De Micheli, G., Fully Integrated Biochip Platforms for Advanced Healthcare. Sensors-Basel 2012, 12, (8), 1101311060.

52. Wang, J., Carbon-nanotube based electrochemical biosensors: A review. Electroanal 2005, 17, (1), 7-14.

53. Kotanen, C. N.; Moussy, F. G.; Carrara, S.; Guiseppi-Elie, A., Implantable enzyme amperometric biosensors. Biosensors \& bioelectronics 2012, 35, (1), 14-26.

54. Rahman, M. M.; Umar, A.; Sawada, K., Development of amperometric glucose biosensor based on glucose oxidase co-immobilized with multi-walled carbon nanotubes at low potential. Sensor Actuat B-Chem 2009, 137, (1), 327-333.

55. Guiseppi-Elie, A., Lei, C., Baughman, R.H., Direct Electron Transfer of Glucose Oxidase on Carbon Nanotubes. Nanotechnology 2002, 13, (5), 559.

56. Kong, T.; Chen, Y.; Ye, Y. P.; Zhang, K.; Wang, Z. X.; Wang, X. P., An amperometric glucose biosensor based on the immobilization of glucose oxidase on the $\mathrm{ZnO}$ nanotubes. Sensor Actuat B-Chem 2009, 138, (1), 344-350.

57. Dai, Z. H.; Shao, G. J.; Hong, J. M.; Bao, J. C.; Shen, J., Immobilization and direct electrochemistry of glucose oxidase on a tetragonal pyramid-shaped porous $\mathrm{ZnO}$ nanostructure for a glucose biosensor. Biosens Bioelectron 2009, 24, (5), 1286-1291. 
58. Tsai, M. C.; Tsai, Y. C., Adsorption of glucose oxidase at platinum-multiwalled carbon nanotube-alumina-coated silica nanocomposite for amperometric glucose biosensor. Sensor Actuat B-Chem 2009, 141, (2), 592-598.

59. Wu, H.; Wang, J.; Kang, X. H.; Wang, C. M.; Wang, D. H.; Liu, J.; Aksay, I. A.; Lin, Y. H., Glucose biosensor based on immobilization of glucose oxidase in platinum nanoparticles/graphene/chitosan nanocomposite film. Talanta 2009, 80, (1), 403-406.

60. Li, X. Y.; Zhou, Y. L.; Zheng, Z. Z.; Yue, X. L.; Dai, Z. F.; Liu, S. Q.; Tang, Z. Y., Glucose Biosensor Based on Nanocomposite Films of CdTe Quantum Dots and Glucose Oxidase. Langmuir 2009, 25, (11), 6580-6586.

61. Marrakchi, M.; Dzyadevych, S. V.; Lagarde, F.; Martelet, C.; Jaffrezic-Renault, N., Conductometric biosensor based on glucose oxidase and beta-galactosidase for specific lactose determination in milk. Mat Sci Eng C-Bio S 2008, 28, (5-6), 872-875.

62. Ammam, M.; Fransaer, J., Two-enzyme lactose biosensor based on beta-galactosidase and glucose oxidase deposited by AC-electrophoresis: Characteristics and performance for lactose determination in milk. Sensor Actuat B-Chem 2010, 148, (2), 583-589.

63. Conzuelo, F.; Gamella, M.; Campuzano, S.; Ruiz, M. A.; Reviejo, A. J.; Pingarron, J. M., An Integrated Amperometric Biosensor for the Determination of Lactose in Milk and Dairy Products. J Agr Food Chem 2010, 58, (12), 7141-7148.

64. Upadhyay, A. K.; Ting, T. W.; Chen, S. M., Amperometric biosensor for hydrogen peroxide based on coimmobilized horseradish peroxidase and methylene green in ormosils matrix with multiwalled carbon nanotubes. Talanta 2009, 79, (1), 38-45.

65. Kafi, A. K. M.; Wu, G.; Chen, A., A novel hydrogen peroxide biosensor based on the immobilization of horseradish peroxidase onto Au-modified titanium dioxide nanotube arrays. Biosens Bioelectron 2008, 24, (4), 566-571.

66. Xi, F. N.; Liu, L. J.; Wu, Q.; Lin, X. F., One-step construction of biosensor based on chitosan-ionic liquid-horseradish peroxidase biocomposite formed by electrodeposition. Biosens Bioelectron 2008, 24, (1), 29-34.

67. Shi, L. H.; Liu, X. Q.; Niu, W. X.; Li, H. J.; Han, S.; Chen, J.; Xu, G. B., Hydrogen peroxide biosensor based on direct electrochemistry of soybean Peroxidase immobilized on single-walled carbon nanohorn modified electrode. Biosens Bioelectron 2009, 24, (5), 1159-1163. 
68. Salimi, A.; Noorbakhsh, A.; Rafiee-Pour, H. A.; Ghourchian, H., Direct Voltammetry of Copper, Zinc-Superoxide Dismutase Immobilized onto Electrodeposited Nickel Oxide Nanoparticles: Fabrication of Amperometric Superoxide Biosensor. Electroanal 2011, 23, (3), 683-691.

69. Cui, R. J.; Huang, H. P.; Yin, Z. Z.; Gao, D.; Zhu, J. J., Horseradish peroxidasefunctionalized gold nanoparticle label for amplified immunoanalysis based on gold nanoparticles/carbon nanotubes hybrids modified biosensor. Biosens Bioelectron 2008, 23, (11), 1666-1673.

70. de Jonge, L. T.; Leeuwenburgh, S. C. G.; van den Beucken, J. J. J. P.; Wolke, J. G. C.; Jansen, J. A., Electrosprayed Enzyme Coatings as Bioinspired Alternatives to Bioceramic Coatings for Orthopedic and Oral Implants. Adv Funct Mater 2009, 19, (5), 755-762.

71. Dinu, C. Z.; Zhu, G.; Bale, S. S.; Anand, G.; Reeder, P. J.; Sanford, K.; Whited, G.; Kane, R. S.; Dordick, J. S., Enzyme-Based Nanoscale Composites for Use as Active Decontamination Surfaces. Adv Funct Mater 2010, 20, (3), 392-398.

72. Pavithra, D.; Doble, M., Biofilm formation, bacterial adhesion and host response on polymeric implants - issues and prevention. Biomed Mater 2008, 3, (3).

73. Kuhlmann, J.; Dzugan, L. C.; Heineman, W. R., Comparison of the Effects of Biofouling on Voltammetric and Potentiometric Measurements. Electroanal 2012, 24, (8), 1732-1738.

74. Asuri, P.; Karajanagi, S. S.; Kane, R. S.; Dordick, J. S., Polymer-nanotube-enzyme composites as active antifouling films. Small 2007, 3, (1), 50-53.

75. Chambers, L. D.; Stokes, K. R.; Walsh, F. C.; Wood, R. J. K., Modern approaches to marine antifouling coatings. Surf Coat Tech 2006, 201, (6), 3642-3652.

76. Holland, R.; Dugdale, T. M.; Wetherbee, R.; Brennan, A. B.; Finlay, J. A.; Callow, J. A.; Callow, M. E., Adhesion and motility of fouling diatoms on a silicone elastomer. Biofouling 2004, 20, (6), 323-329.

77. Berglin, M.; Wynne, K. J.; Gatenholm, P., Fouling-release coatings prepared from alpha,omega-dihydroxypoly(dimethylsiloxane) cross-linked with (heptadecafluoro-1,1,2,2tetrahydrodecyl)triethoxysilane. J Colloid Interf Sci 2003, 257, (2), 383-391.

78. Volk, R. B., Antialgal activity of several cyanobacterial exometabolites. J Appl Phycol 2006, $18,(2), 145-151$. 
79. Roper, K. E.; Beamish, H.; Garson, M. J.; Skilleter, G. A.; Degnan, B. M., Convergent Antifouling Activities of Structurally Distinct Bioactive Compounds Synthesized Within Two Sympatric Haliclona Demosponges. Mar Biotechnol 2009, 11, (2), 188-198.

80. Tiller, J. C.; Lee, S. B.; Lewis, K.; Klibanov, A. M., Polymer surfaces derivatized with poly(vinyl-N-hexylpyridinium) kill airborne and waterborne bacteria. Biotechnol Bioeng 2002, 79, (4), 465-471.

81. Cousins, C. M.; Allan, C. D., Sporicidal Properties of Some Halogens. J Appl Bacteriol 1967, 30, (1), 168-\&.

82. NIOSH, Guidelines for protecting the safety and health of health care workers. In 1988; pp $88-119$.

83. Grover, N., Douaisi, M., Borkar, I., Lee, L., Dinu, C., Kane, R., Dordick, J., PerhydrolaseNanotube Paint Composites with Sporicidal and Antiviral Activity. Journal of Microbiology and Biotechnology, in press 2012.

84. Asuri, P.; Karajanagi, S. S.; Yang, H. C.; Yim, T. J.; Kane, R. S.; Dordick, J. S., Increasing protein stability through control of the nanoscale environment. Langmuir 2006, 22, (13), 58335836.

85. Takahara, Y. K.; Hanada, Y.; Ohno, T.; Ushiroda, S.; Ikeda, S.; Matsumura, M., Photooxidation of organic compounds in a solution containing hydrogen peroxide and $\mathrm{TiO} 2$ particles under visible light. J Appl Electrochem 2005, 35, (7-8), 793-797.

86. Khodadoust, S.; Sheini, A.; Armand, N., Photocatalytic degradation of monoethanolamine in wastewater using nanosized TiO2 loaded on clinoptilolite. Spectrochim Acta A 2012, 92, 91-95. 


\title{
CHAPTER 2
}

\section{A SYSTEMATIC STUDY OF THE ENZYME-NANOSUPPORT INTERFACE}

\begin{abstract}
Enzymes have potential applications in industrial catalysis, biosensing, drug delivery and decontamination, but have limited usage due to their low operational stability and yield loss in synthetic environments. Enzyme immobilization onto nano-sized solid supports has been proposed as an alternative to ensure enzyme stability retention and recovery. However, the nanosupport has often been shown to affect the enzyme activity; a deep understand of the enzyme-nanointerface reaction is thus needed if advances in the listed applications are to be made. Herein, we present a comprehensive and systematic study of the interface reactions between enzymes and nanosupports with different characteristics (i.e. surface area, charge and aspect-ratios). The interface reactions are discussed relative to the enzyme kinetics and retained activity at the nanosupports. Knowledge gained from this study can further be used to optimize enzyme-nanomaterial interactions in order to maintain optimal levels of enzyme activity while enhancing stability upon immobilization for use in a broad spectrum of applications.
\end{abstract}

\section{INTRODUCTION}

Enzymes are a naturally occurring class of proteins that possess excellent catalytic properties including activity, selectivity and specificity. They are environmentally friendly and generally produce fewer harsh byproducts than their chemical counterparts ${ }^{1-4}$. Thus, they are very attractive to industries that generate products via chemical reaction such as in the fine chemical, pharmaceutical and agrochemical industries ${ }^{5,6}$. In their review, Wandrey et al list the past and current states of industrial biocatalysis and elaborate on its promising future with new developments in enzyme technologies ${ }^{7}$. However, before such applications can be implemented at an industrial scale there are several enzyme properties that must be improved, such as solubility, stability and inhibition ${ }^{1,8,9}$. For instance, Aburto et al explain the usefulness of the enzyme chloroperoxidase in the petroleum refining industry, but also how its application in this process is limited due to low enzyme operational stability ${ }^{10}$. Similarly, Garcia-Galan et al describe the potential uses of various enzymes in chemical industries ranging from 
pharmaceuticals to energy or food production and focus on ways (methods) to improve their unsuitable characteristics in order to make their use a possibility ${ }^{8}$.

A common approach used to enhance enzyme activity and stability for synthetic applications consists of immobilization of enzyme onto nano-sized solid supports. Immobilization was shown to enhance the stability of the enzymes ${ }^{8,9,11}$ while the high aspect ratio of the nanosupports allowed conjugate retention in solution and an ease of conjugate recovery via filtration ${ }^{12,13}$. In addition to industrial advantages, interest in enzyme immobilization has also greatly increased recently due to its growing number of applications in biotechnology, such as biosensing ${ }^{11,14-17}$, drug delivery $^{13,18,19}$ and decontamination 9 12, 20, 21 . For example, Shi et al have shown how the immobilization of glucose oxidase improves its stability and specificity for use in glucose biosensors ${ }^{16}$ and Dinu et al have shown increased stability of the enzyme perhydrolase S54V at high temperatures upon immobilization for use in active surface decontamination ${ }^{9}$.

However, enzyme immobilization can also have an adverse effect on its activity due to possible enzyme non-specific binding at the nanointerface and thus possible enzyme deformation of its active site upon attachment ${ }^{22,23}$. It is thought that these effects are not only influenced by the properties of the enzyme but also by the characteristics of the nanosupports, as well as the immobilization method being used ${ }^{8,10,13,24,25}$. However, to date, the preliminary studies have only looked at isolated enzymes and isolated nanosupports (e.g. Besteman et al report on the use of single-walled carbon nanotubes as a support for glucose oxidase immobilization for use in biosensing, but do not investigate any other supports or enzymes ${ }^{26}$, and Luckarift et al examine the use of biomimetic silica supports to improve retained activity of butyrylcholimesterase but do not test any other enzymes or multiple immobilization methods ${ }^{27}$ ), with no clear translation being suggested on how these studies could be transferred to other enzymes or how they could be tailored to the function of that enzyme implementated in alternative technologies. In particular, the activity of an enzyme immobilized at a nanosupport interface, and the correlation between the enzyme (i.e. surface properties, molecular weight, isoelectric point, structure) and the nanosupport characteristics (i.e. physical and chemical properties, the rate of curvature), or between the immobilization technique (i.e. physical or chemical binding) and the nanointerface reactions in water-based environments, is not well understood.

We propose to investigate the underlying complex mechanisms that influence enzyme behavior at nanointerfaces. We have focused our analyses on three model systems, i.e. enzymes 
of different molecular weight and surface properties characteristics (soybean peroxidase (SBP, $40 \mathrm{kDa})$, glucose oxidase $\left(\mathrm{GO}_{\mathrm{X}}, 180 \mathrm{kDa}\right)$, and chloroperoxidase $\left.(\mathrm{CPO}, 42 \mathrm{kDa})\right)$ with unique potential for synthetic applications. The model systems have been immobilized at nanointerfaces with varying aspect ratios (i.e. SWCNTs, diameter 0.8-1.2 nm), multi-walled carbon nanotubes (MWCNTs, diameter 10-20 nm) and graphene oxide nanosheets (GON, dimensions 500-5,000 $\mathrm{nm}$ sheets)) using three separate methods (i.e. physical adsorption, covalent binding and covalent binding with an amino- $\mathrm{dPEG}_{8}-\mathrm{COOH}$ linker (PEG)). The selected enzymes have interesting applications as well as similarities and differences in their properties to ensure a meaningful analysis at the nanointerface. SBP was chosen to be used as a model enzyme because of its relatively high inherent stability ${ }^{28-30}$. CPO was chosen due to its potential both as an oxidizer in industry and as the source of a strong decontaminant ${ }^{10,20}$. Grover et al showed the bactericidal capability of immobilized CPO against Escherichia coli when incorporated into a surface coating ${ }^{20}$. $\mathrm{GO}_{\mathrm{X}}$ was chosen because of its widely studied use in biosensors to detect glucose concentrations $^{16,31-33}$. Further, the effects of enzyme size on immobilization can be determined using these enzymes due to the much larger size of $\mathrm{GO}_{\mathrm{X}}$ compared to the similar smaller sizes of SBP and CPO. The characteristics of the enzyme and nanointerface were also investigated and the impact of the nanointerface on the enzyme kinetics is discussed. By determining how different factors at the enzyme-nanomaterial interface will affect the immobilized enzyme, a greater control over conjugate formation can be accomplished and thus further utilized in a wide array of applications. Further, the fundamental knowledge gained through such studies could lead to user-controlled tailoring of the biological material-nano interface for increased activity, stability and shelf life of enzyme-based synthetic applications (i.e. biosensors).

\section{MATERIALS AND METHODS}

\section{GRAPHENE OXIDE NANOSHEET SYNTHESIS}

Graphene oxide nanosheets (GON) were produced from regular graphite powder (Alfa Aesar, 99.8\% purity). First, $10 \mathrm{~g}$ of the graphite powder and $5 \mathrm{~g}$ of $\mathrm{NaNO}_{3}$ (Sigma Aldrich, 99.0\%) were added to $230 \mathrm{~mL}$ of concentrated sulfuric acid (Fisher Scientific, 96.4\%) in a $200 \mathrm{~mL}$ flask and placed in an ice bath with slow stirring. $30 \mathrm{mg}$ of $\mathrm{KMnO}_{4}$ (Sigma Aldrich, 99.0\%) was then added slowly to ensure that the mixture temperature remained below $20^{\circ} \mathrm{C}$. Next, the solution was heated to $35^{\circ} \mathrm{C}$ for $30 \mathrm{~min}$, diluted in $460 \mathrm{~mL}$ of deionized (DI) water and quickly heated to 
$98^{\circ} \mathrm{C}$ for $15 \mathrm{~min}$. The mixture was then rediluted in $710 \mathrm{~mL}$ of $\mathrm{DI}$ water preheated to $35^{\circ} \mathrm{C}$ and treated with $30 \mathrm{~mL}$ of $30 \% \mathrm{H}_{2} \mathrm{O}_{2}$ (Sigma Aldrich). Finally, the solution was filtered and washed using DI water at $35^{\circ} \mathrm{C}$ until the effluent was mostly clear with a $\mathrm{pH}$ of 6 . The resulting brown filter cake was then dried in a vacuum oven to obtain a distinctly brown powder, which was stored at room temperature until use.

\section{CARBON-BASED MATERIALS ACIDS FUNCTIONALIZATION}

Functionalized carbon-based materials (CMATs) (single wall carbon nanotubes -SWCNTs, 85\% purity, Unidym Inc.; multi-walled carbon nanotubes- MWCNTs, 95\% purity, NanoLab Inc.; or graphene oxide nanosheets- GON) were prepared via acids treatment as previously described ${ }^{9}$,

${ }^{34}$. Briefly, $100 \mathrm{mg}$ of pristine CMATs were added to a $60 \mathrm{~mL}$ mixture of $3: 1(\mathrm{~V}: \mathrm{V})$ sulfuric acid (Fisher Scientific, 96.4\%) and nitric acid (Fisher Scientific, 69.6\%). The mixture was subsequently ultrasonicated for $6 \mathrm{~h}$ (Branson 2510, Fisher Scientific) in ice at a constant temperature of approximately $25^{\circ} \mathrm{C}$. Next, the solution was diluted with DI water and filtered through a GTTP $0.2 \mu \mathrm{m}$ polycarbonate membrane (Fisher Scientific). Several cycles of redispersion and filtration in DI water were used to remove acidic residues or catalysts. The CMATs isolated on the filter were then dried in a vacuum desiccator and stored at room temperature until use.

\section{CARBON-BASED MATERIALS CHARACTERIZATION}

CMATs were characterized using scanning electron microscopy (SEM), energy-dispersive xray spectroscopy (EDX), and Fourier transform infrared spectroscopy (FTIR) for sample morphology and elemental composition, and to evaluate the chemical structure, respectively. For SEM and EDX characterizations, the samples $(1 \mathrm{mg} / \mathrm{mL}$ in DI water) were deposited on silica wafers and dried under vacuum. Experiments were performed on a Hitachi S-4700 Field Emission Scanning Electron Microscope with a S-4700 detector combining secondary (SE) and backscattered (BSE) electron detection (in a single unit). FTIR data were collected in transmission mode using $\mathrm{KBr}$ pellet method on a Thermo Nicolet Instrument.

The length of pristine and functionalized SWCNTs and MWCNTs was quantified using atomic force microscopy (AFM) with a Si tip (Asylum Research, 50-90 KHz AC240TS) and tapping mode in air. Briefly, nanotube samples in DI water $(0.1 \mathrm{mg} / \mathrm{mL})$ were deposited onto 
mica surfaces (9.5 mm diameter, 0.15-0.21 mm thickness, Electron Microscopy Sciences) and dried under vacuum overnight. Scan images of $10 \mu \mathrm{m} \times 10 \mu \mathrm{m}$ and $1 \mu \mathrm{m} \times 1 \mu \mathrm{m}$ areas were obtained $^{35}$.

To evaluate the degree of hydrophilicity/hydrophobicity of the CMATs, dispersity tests were performed in DI water ( $\mathrm{pH}$ 6.25), phosphate buffered saline (PBS, $100 \mathrm{mM}, \mathrm{pH}$ 7, Sigma Aldrich) and citric acid buffer (CAB 50 mM, pH 4.8, Sigma Aldrich). Briefly, CMATs were first dispersed in each of the different solvents at a concentration of $3 \mathrm{mg} / \mathrm{mL}$. The suspension was then centrifuged at $3000 \mathrm{rpm}$ for $5 \mathrm{~min}$ and $0.8 \mathrm{~mL}$ of the resulting supernatant was removed and filtered through the GTTP $0.2 \mu \mathrm{m}$ polycarbonate filter membrane. The filters were subsequently dried under vacuum and the amount of CMATs on the filter was weighed. Dispersity was calculated based on the volume suspended and the initial amount used in the dispersion test.

\section{ENZYME IMMOBILIZATION}

Soybean peroxidase (SBP, Bioresearch), glucose oxidase $\left(\mathrm{GO}_{\mathrm{X}}\right.$, Type VII, Sigma), and chloroperoxidase (CPO, Bioresearch) were immobilized onto CMATs using either physical or chemical binding. Briefly, for physical binding $2 \mathrm{mg}$ of CMATswere first dispersed in $2 \mathrm{~mL}$ of enzyme solution $\left(1 \mathrm{mg} / \mathrm{ml}\right.$ in PBS for SBP, $0.5 \mathrm{mg} / \mathrm{mL}$ in $\mathrm{PBS}$ for $\mathrm{GO}_{\mathrm{X}}$, or $0.5 \mathrm{mg} / \mathrm{mL}$ in CAB for CPO) via brief sonication. The solution was then incubated at room temperature for $2 \mathrm{~h}$ with shaking at $200 \mathrm{rpm}$. Next, the enzyme-CMAT conjugates were recovered by filtration using the GTTP $0.2 \mu \mathrm{m}$ polycarbonate filter membrane. The supernatant was isolated and its volume recorded. The conjugates on the filter were then washed at least 6 times using the corresponding buffer ( $2 \mathrm{~mL}$ for each wash) to remove loosely bound enzyme, with the first two washes being isolated and their volumes recorded. Finally, the conjugates were redispersed in $2 \mathrm{~mL}$ of the corresponding buffer and stored at $4{ }^{\circ} \mathrm{C}$.

For chemical binding, $2 \mathrm{mg}$ of CMATs were first activated using 1-ethyl-3-[3dimethylaminopropyl] carbodiimide (EDC, Acros Organics) and N-hydroxysuccinimide (NHS, Pierce). Specifically, the CMATs were dispersed in $160 \mathrm{mM}$ EDC and $80 \mathrm{NHS}$ in 2-(Nmorpholino)ethanesulfonic acid sodium salt buffer (MES, $50 \mathrm{mM}, \mathrm{pH} 4.7$ ) with a final volume of $2 \mathrm{~mL}$ via sonication, and incubated at room temperature for $15 \mathrm{~min}$ with shaking at $200 \mathrm{rpm}$. Subsequently, the mixture was filtered through the GTTP $0.2 \mu \mathrm{m}$ polycarbonate filter membrane and washed thoroughly with MES to remove any ester residues. Next, the activated CMATs 
were immediately dispersed in $2 \mathrm{~mL}$ of the selected enzyme solution (consistent with physical binding) and incubated at room temperature for $3 \mathrm{~h}$ with shaking at $200 \mathrm{rpm}$. Enzyme-CMAT conjugates were then recovered and washed, with the supernatant and the two washes recovered, as previously described (see physical binding). Finally, the conjugates were redispersed in $2 \mathrm{~mL}$ of the corresponding buffer and stored at $4{ }^{\circ} \mathrm{C}$.

For chemical binding through a spacer, $2 \mathrm{mg}$ of the selected CMATs were first activated with EDC and NHS chemistry as previously described (see covalent binding), and subsequently dispersed in $5 \mathrm{~mL}$ of $1 \mathrm{mg} / \mathrm{mL}$ Amino- $\mathrm{CPEG}_{8}-\mathrm{COOH}$ (PEG, $32.2 \AA$, Quanta Biodesign) in the necessary buffer and incubated at room temperature for $3 \mathrm{~h}$ with shaking at $200 \mathrm{rpm}$. The resulting conjugates were then filtered and washed with the necessary buffer. Finally, the selected enzyme was attached to the PEG linker using the covalent attachment protocol as previously described. Conjugates were then redispersed in $2 \mathrm{~mL}$ of the required buffer and stored at $4{ }^{\circ} \mathrm{C}$.

\section{ENZYME LOADING}

The amount of enzyme attached to the CMATs (defined as enzyme loading) was determined using the standard BCA Assay (Pierce) and by subtracting the amount of enzyme washed off in the supernatant and the first two washes collected after the immobilization from the initial amount added to the CMATs in the immobilization process ${ }^{9,12}$. Briefly, $1 \mathrm{~mL}$ working reagent containing 50 parts reagent A with 1 part reagent B (reagents were provided stock with the BCA Assay kit) was mixed with $50 \mu \mathrm{L}$ of enzyme solution (either from the supernatant or the washes) and incubated at $37^{\circ} \mathrm{C}$ for $30 \mathrm{~min}$. Absorbance at $562 \mathrm{~nm}$ was recorded for each sample using a UV-Vis spectrophotometer (Thermo Scientific EVO300) and compared to a calibration curve of known concentrations of the respective enzyme (free in solution) in the working reagent. Loadings were estimated as the difference between the amount of enzyme washed out and the known initial amount of enzyme added during the incubation.

\section{ENZYME ACTIVITY ASSAY}

Enzyme retained activity was determined using colorimetric reactions monitored in a UV-Vis spectrophotometer (Thermo Scientific EVO300). Enzyme retained activity was calculated by 
comparing the activity of immobilized enzyme to the activity of the free enzyme in solution at the same concentration.

Specifically, the activity of SBP was determined by monitoring the oxidation of (2,2'Azinobis[3-ethylbenzothiazoline-6-sulfonic acid]) (ABTS, Sigma Aldrich) by SBP in the presence of hydrogen peroxide $\left(\mathrm{H}_{2} \mathrm{O}_{2}\right.$, Sigma Aldrich) at $412 \mathrm{~nm}$. Briefly, $20 \mu \mathrm{L}$ of the SBP solution to be tested (free or immobilized) was added to $650 \mu \mathrm{L}$ of $0.25 \mathrm{mg} / \mathrm{mL}$ ABTS and mixed in a plastic cuvette. Next, $20 \mu \mathrm{L}$ of $6.5 \mathrm{mM} \mathrm{H}_{2} \mathrm{O}_{2}$ was added to initiate the reaction and the cuvette was immediately placed in the spectrophotometer and rate of absorbance change monitored for $2 \mathrm{~min}$. The initial reaction rate was calculated from the slope of the linear time-

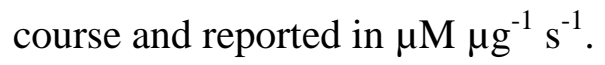

The reaction used to determine the activity of SBP was also used to determine the activity of $\mathrm{GO}_{\mathrm{X}}$. However, in this assay, the $\mathrm{GO}_{\mathrm{X}}$ produces the required $\mathrm{H}_{2} \mathrm{O}_{2}$. Briefly, $400 \mu \mathrm{L}$ of PBS, 250 $\mu \mathrm{L}$ of $0.25 \mathrm{mM}$ glucose (ACROS), $250 \mu \mathrm{L}$ of $0.25 \mathrm{mg} / \mathrm{mL}$ ABTS, and $50 \mu \mathrm{L}$ of $0.5 \mathrm{mg} / \mathrm{mL} \mathrm{SBP}$ were first mixed in a plastic cuvette. Then, $50 \mu \mathrm{L}$ of the $\mathrm{GO}_{\mathrm{X}}$ sample to be tested was added to initiate the reaction and the cuvette was immediately placed in the spectrophotometer and rate of absorbance change monitored for $2 \mathrm{~min}$. The initial reaction rate was calculated from the slope of

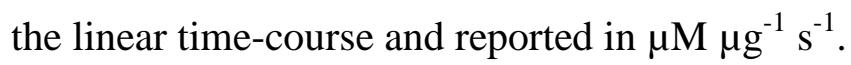

The activity of CPO was determined by monitoring the conversion of 2-chloro-5,5-dimethyl1,3-cyclohexanedione (monochlorodimedon, Alfa Aesar) to dichlorodimedon by CPO in the presence of $\mathrm{Cl}^{-}$and $\mathrm{H}_{2} \mathrm{O}_{2}$ at $278 \mathrm{~nm}$. Briefly, $500 \mu \mathrm{L}$ of CAB, $440 \mu \mathrm{L}$ of $227.27 \mathrm{mM} \mathrm{NaCl}$ (ACROS), $20 \mu \mathrm{L}$ of $5 \mathrm{mM}$ monochlorodimedon, and $20 \mu \mathrm{L}$ of the CPO sample to be tested were first mixed in a quartz cuvette. Then, $20 \mu \mathrm{L}$ of $50 \mathrm{mM} \mathrm{H}_{2} \mathrm{O}_{2}$ was added to initiate the reaction and the cuvette was immediately placed in the spectrophotometer and rate of absorbance change monitored for 2 min. The initial reaction rate was calculated from the slope of the linear time-

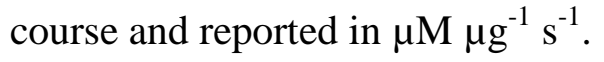

\section{ENZYME KINETIC PARAMETERS DETERMINATION}

The kinetic parameters, $\mathrm{K}_{\mathrm{m}}$ and $\mathrm{V}_{\max }$ values, of the free and immobilized enzyme (onto all CMATs) were determined by measuring the initial rates of reaction in the respective activity assays (previously described), with varying substrate concentrations. Specifically, for SBP the concentration of $\mathrm{H}_{2} \mathrm{O}_{2}$ was varied from 0 to $0.04 \mathrm{mM}$ final concentration, for $\mathrm{GO}_{\mathrm{X}}$ the 
concentration of glucose was varied from 0 to $100 \mathrm{mM}$ final concentration and for CPO the concentration of $\mathrm{H}_{2} \mathrm{O}_{2}$ was varied from 0 to $4 \mathrm{mM}$ final concentration. The $\mathrm{K}_{\mathrm{m}}$ and $\mathrm{V}_{\max }$ values for the free and immobilized enzyme were calculated using Line weaver-Burk plots using the initial rate of the enzymatic reaction ${ }^{36,37}$ :

$\frac{1}{v}-\frac{k_{m}}{v_{\mathrm{m}}[S]_{\mathrm{x}}}+\frac{1}{v_{\mathrm{m}}}$, where $[\mathrm{S}]$ is the concentration of the substrate in $\mathrm{mM}, \mathrm{V}$ and $\mathrm{V}_{\max }$ represent

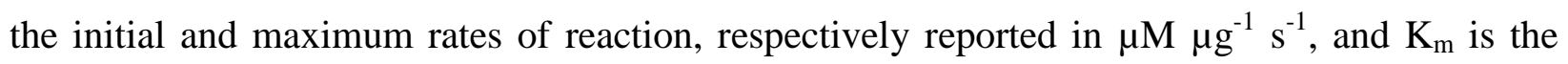
Michaelis-Menten constant reported in $\mathrm{mM}$.

\section{STATISTICAL ANALYSIS}

All results are presented as mean \pm standard deviation with at least six trials for each statistic.

\section{RESULTS AND DISCUSSION}

Three different carbon-based materials with different dimensions have been used in this study. These nanosupports vary in rate of surface curvature, as well as surface hydrophilicity/hydrophobicity. Both of these characteristics have been shown to affect the retained activity of immobilized enzymes ${ }^{11,17,38}$. It was hypothesized that supports with a lower rate of curvature would have a more detrimental effect on the enzyme activity and kinetics as more of the enzyme will come into contact with the surface of the nanosupport and thus increase loss of surface area available for substrate interaction as well as enzyme denaturation. These nanosupports were chosen not only because of their varying characteristics but also for their proven benefits. MWCNTs ${ }^{12,32,33,39,40}$, SWCNTs $^{9,11,13,39}$ and GON $^{41-43}$ have all been widely studied as supports for enzyme immobilization with promising results in multiple applications. The level of carboxyl functionality and thus hydrophillicity of these nanosupports was enhanced via acid functionalization prior to enzyme immobilization ${ }^{34}$.

\section{MORPHOLOGY AND STRUCTURE CHARACTERIZATION OF CARBON-BASED MATERIALS (CMATS)}

In particular, pristine SWCNTS (diameter $=0.8-1.2 \mathrm{~nm}$, length $=760 \pm 276 \mathrm{~nm}$ ), MWCNTs $($ diameter $=10-20 \mathrm{~nm}$, length $=6,049 \pm 2,954 \mathrm{~nm})$ and GON $($ dimensions $=500-5,000 \mathrm{~nm})$ were acid functionalized as previously described ${ }^{12,34}$. Briefly, the CMATs were incubated in a 
strong acids mixture, containing nitric and sulfuric acid for $6 \mathrm{~h}$. To evaluate the effect of acids functionalization on the structure and morphology of the nanomaterials, the CMATs were examined using scanning electron microscopy (SEM), atomic force microscopy (AFM), energy dispersive X-ray analysis (EDX) and Fourier transform infrared spectroscopy (FTIR) before and after acids functionalization.

The typical morphologies of the pristine and functionalized SWCNTs and MWCNTs as investigated by Scanning Electron Microscopy (SEM) are shown in Figure S1 (Appendix 1). The SEM investigations of CMATs showed that acid treatment did not affect the overall morphology of the samples (Figure S1, Appendix 1); however, atomic force microscopy (AFM) analysis in tapping mode showed that acid treatment reduced the length of both SW- and MWCNTs. Briefly, upon acid functionalization SWCNTs were shortened from $760 \pm 276 \mathrm{~nm}$ to $516 \pm 277$ $\mathrm{nm}$ and MWCNTs were shortened from 6,049 $\pm 2,954 \mathrm{~nm}$ to $452 \pm 213 \mathrm{~nm}$. Diameters of the SWCNTs and MWCNTs were unaffected by acid treatment and were 0.8-1.2 nm and 10-20 nm, respectively. The dimensions of the GON were 500-5,000 nm (sheets). EDX analysis (Figure S1, Appendix 1) showed that the oxygen content increased when compared to carbon and other elements for all the acids treated samples ${ }^{44,45}$. Similar to previous research, this increase was due to acids treatment suggesting carboxyl functionalization onto the CMATs surface ${ }^{34}$.

FTIR data further confirmed grafting of carboxyl functionalities upon acid treatment onto CMATs surface (Figure 1). In particular, the FTIR spectra analysis of acid treated SWCNTs and MWCNTs revealed the presence of intensive bands at wavenumbers around 3450, 2900, 17501550, and 1300-950 $\mathrm{cm}^{-1}$ (Figure $1 \mathrm{a}, \mathrm{b}$ ). The $\sim 2900$ and $3450 \mathrm{~cm}^{-1}$ peaks were generally associated with the presence of hydroxyl moieties and/or hydroxyl moieties in carboxyl groups ${ }^{46}$. The presence of the spectrum band in between 1750 to $1550 \mathrm{~cm}^{-1}$ was associated with the formation of carbonyl and carbon-carbon bonds, respectively ${ }^{46}$. The intensity of the bands in the range of $1300-950 \mathrm{~cm}^{-1}$ are characteristic of carbon-oxygen bond formation, confirming the presence of large amounts of hydrated surface oxides and thus carboxyl functionalization. Further, the FTIR spectra of the GON is presented in Figure 1 c. Prominent peaks can be observed at wavenumbers 3400-3200 $\mathrm{cm}^{-1}, \sim 1740 \mathrm{~cm}^{-1}, \sim 1620 \mathrm{~cm}^{-1}$ and $1400-1060 \mathrm{~cm}^{-1}$. The large peak in the range $3400-3200 \mathrm{~cm}^{-1}$ was indicative of $-\mathrm{OH}$ groups present at the surface of the nanosupport in the form of carboxylic acids or intercalated water ${ }^{47}$. The peak at $\sim 1740 \mathrm{~cm}^{-1}$ resulted from the $\mathrm{C}=\mathrm{O}$ bond in carboxylic acids groups as well as carbonyl moieties. The $\sim 1620$ 
$\mathrm{cm}^{-1}$ peak showed the presence of $\mathrm{C}=\mathrm{C}$ bonds resulting from un-oxidized regions of the graphene. Finally, the large band at $1400-1060 \mathrm{~cm}^{-1}$ was a product of carboxyl groups and epoxy or alkoxy groups at the surface of the material ${ }^{47}$. Our results were in agreement with previous studies, which showed that that liquid phase oxidation with strong acids mixtures introduces chemical property changes and adds free carboxylic acid groups to CMATs ${ }^{46,47}$.

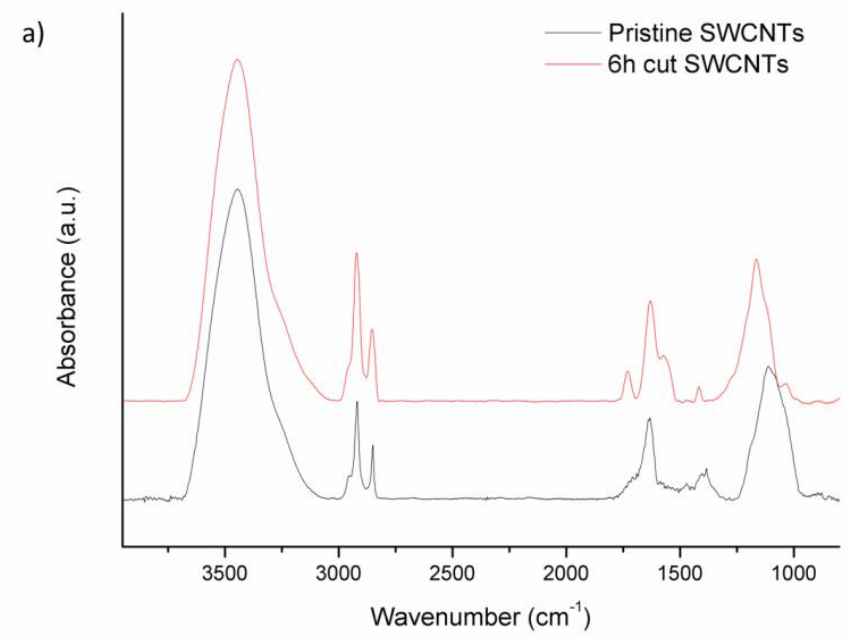

b)

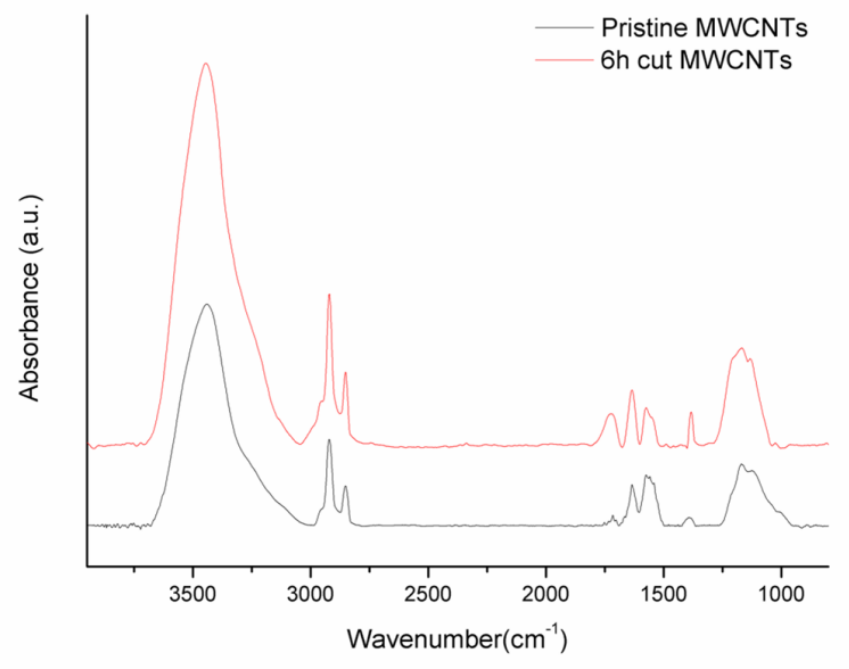




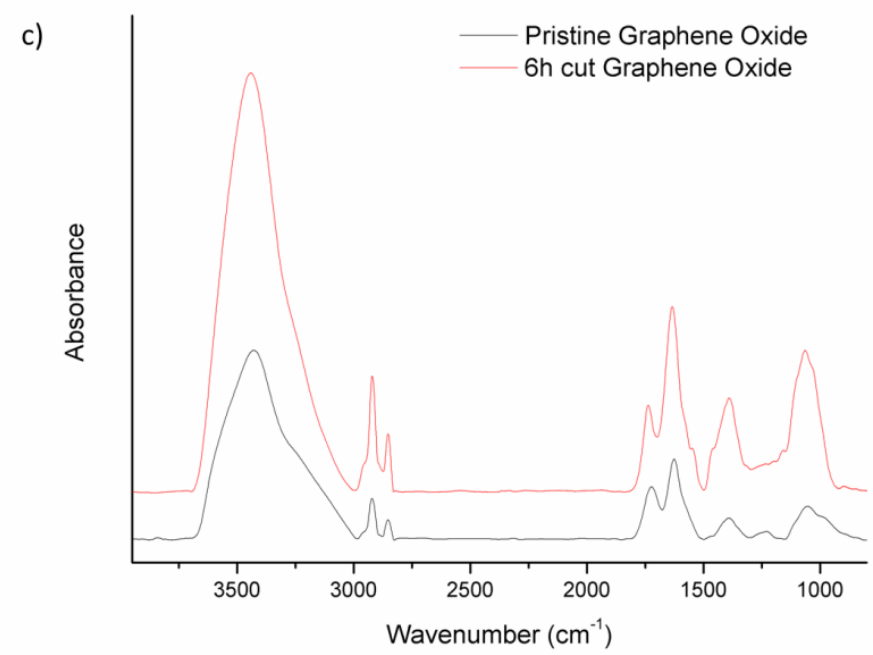

Figure 1: FTIR spectra analysis of a) pristine and acid functionalized single-walled carbon nanotubes, b) pristine and acid functionalized multi-walled carbon nanotubes and c) pristine and acid functionalized graphene oxide nanosheets. FTIR spectra confirms the presence of carboxyl functionalizations in the acid functionalized samples.

Carboxyl functionalization upon acid treatment also improved the CMATs dispersions in several water-based environments ${ }^{34}$. Specifically, Table S1 (Appendix 1) shows that in all solutions used, i.e. DI water ( $\mathrm{pH}$ 6.25), phosphate saline buffer (PBS, $\mathrm{pH} \mathrm{7,100} \mathrm{mM)} \mathrm{and} \mathrm{citric}$ acid buffer (CAB, pH 4.9, $50 \mathrm{mM}$ ), the solubility of CMATs was improved upon the acid treatment up to a 13.5 fold increase observed in CAB for GON. For example, in DI water, the solubility of SWCNTs, MWCNTs and GON improved 9.3 fold, 6.8 fold and 6.5 fold, respectively.

INFLUENCE OF THE IMMOBILIZATION CONDITIONS AND THE CMATS PROPERTIES ON THE ENZYME IMMOBILIZATION

The acid functionalized CMATs were further used for enzyme immobilization. Three different enzymes, namely, soybean peroxidase (SBP), chloroperoxidase (CPO) and glucose oxidase $\left(\mathrm{GO}_{\mathrm{X}}\right)$, were immobilized onto SWCNTs and MWCNTs using three immobilization conditions: physical adsorption, covalent binding, and covalent binding through a PEG linker. SBP was further immobilized onto GON using each immobilization technique in order to further 
test the impact of nanosupport characteristics. This investigation is conceptually represented in Figure 2.

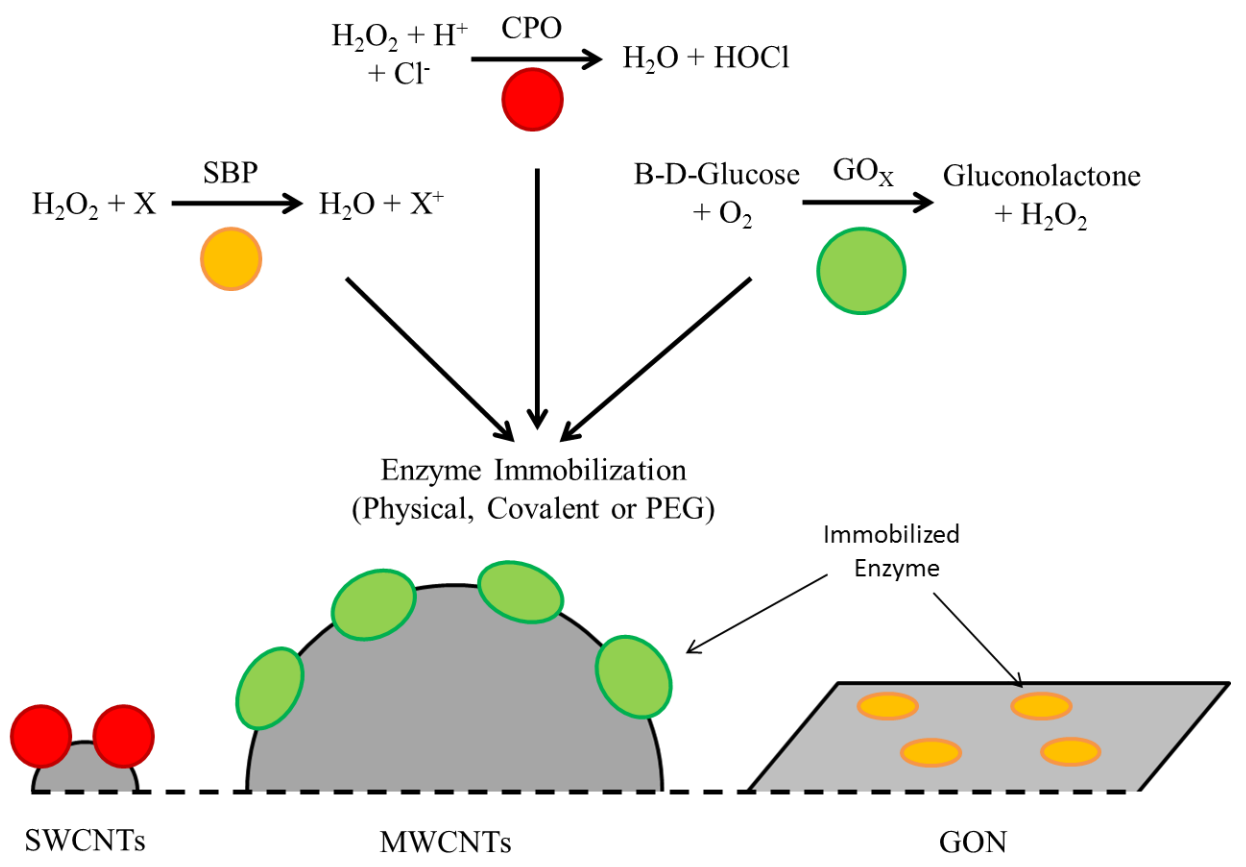

Figure 2: Conceptual image depicting the reaction mechanic of each respective enzyme as well as the immobilization procedure. Surface curvature impacts enzyme structure upon immobilization.

Direct physical adsorption is a simple method of protein immobilization with generally high loadings, but can result in unwanted protein-protein interactions (i.e. two or more enzymes in contact resulting in decreased available surface area) and enzyme leaching over time ${ }^{48,} 49$. Covalent binding was accomplished through the use of the zero length cross-linker 1-ethyl-3-(3dimethylaminopropyl)carbodiimide (EDC). This slightly more complex method allows for stronger binding that will also decrease protein-protein interactions due to more directed binding ${ }^{50-52}$. Directed covalent binding through a PEG linker serves to bring each immobilized enzyme away from other enzymes as well as the surface of the nanosupport to prevent protein deformation and increase available surface area ${ }^{12,31,53}$.

After immobilization, the amount of enzyme attached to the surface, denoted as enzyme loading, and the activity of the enzyme compared to free enzyme at the same amount were determined. Loading amounts were estimated by subtracting the amount of enzyme washed out after the incubation process from the initial amount of enzyme added, and are reported as mg of enzyme per mg of nanosupport. All loading and specific retained activity data for each trial 
involving physical adsorption, covalent binding and covalent binding through a PEG linker are respectively shown in supporting information Tables S2, S3 and S4 (Appendix 1).

A comparison of the specific retained activities of each enzyme immobilized onto the three different nanosupports using physical adsorption, covalent binding and covalent binding through a PEG linker are shown in Figure 3 a, b and c, respectively. Each graph shows the retained activity of SBP, $\mathrm{CPO}$ and $\mathrm{GO}_{\mathrm{X}}$ arranged in order of enzyme increasing molecular weight as immobilized onto SWNCTs, MWCNTs and GON. The CMATs supports are also arranged in order of their increasing diameter (decreasing surface curvature) from left to right for each respective immobilization technique. As can be seen in all three graphs, the specific retained activity varies significantly with the nanosupports being tested. Previous reports have shown that enzymes immobilized onto nanosupports with smaller diameters and thus higher rates of curvature tend to retain higher levels of activity ${ }^{38,54}$. Reasoning for this finding states that the higher rate of curvature of the support results in an increased center-to-center distance between two adjacent immobilized enzymes, which would reduce or totally prevent the unwanted interactions between these neighboring proteins ${ }^{38}$. Additionally, when an enzyme is attached to the surface of a nanomaterial, and because of the increased enzyme deformation at the nanointerface, the enzyme surface area that interacts with the nanosupport increases along with increasing nanosupport diameter. This could potentially increase enzyme denaturation as well as decrease substrate interaction (Figure 2$)^{1,9}$. These effects are also compounded by the previously mentioned protein-protein interactions ${ }^{38}$. Specifically, Asuri et al found that not only did the suggested increased protein-protein interactions caused by a less curved surface cause lower initial activity loss upon immobilization but also caused a more dramatic activity loss over time in harsh environment ${ }^{54}$. 
a)

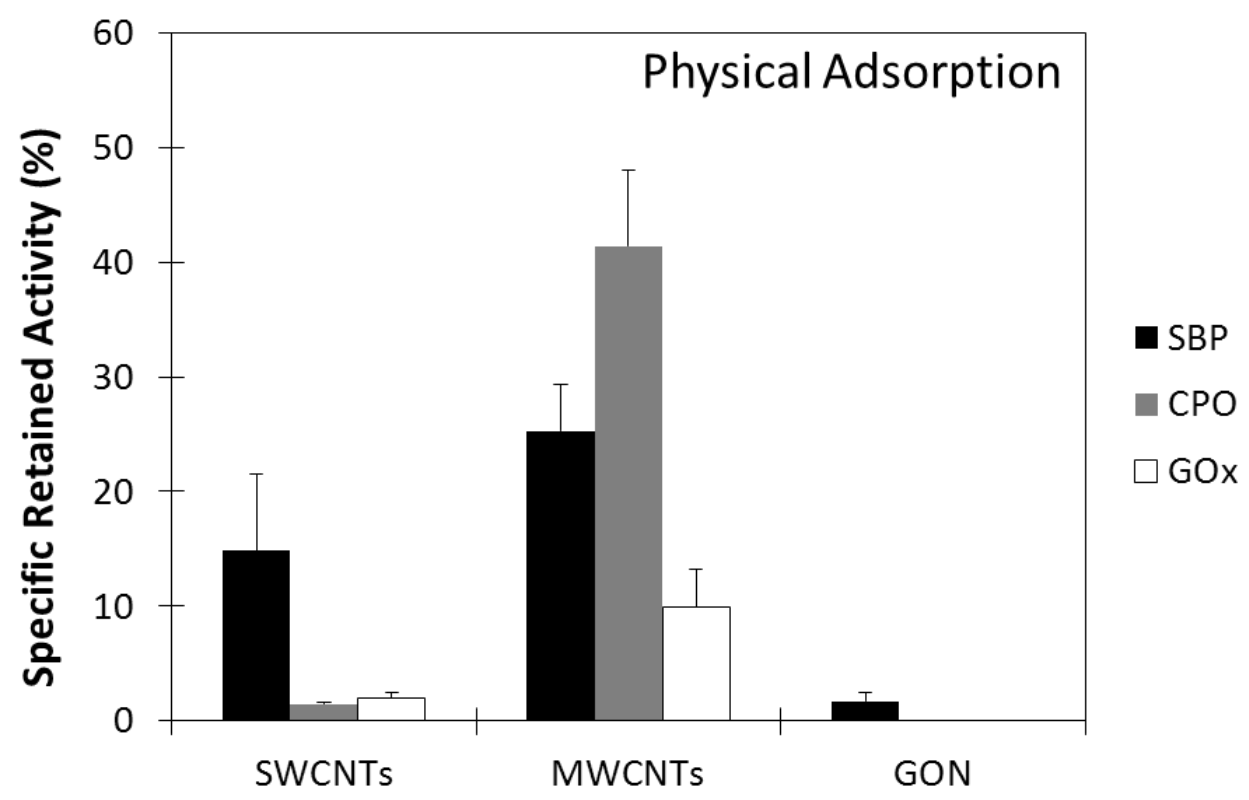

b)

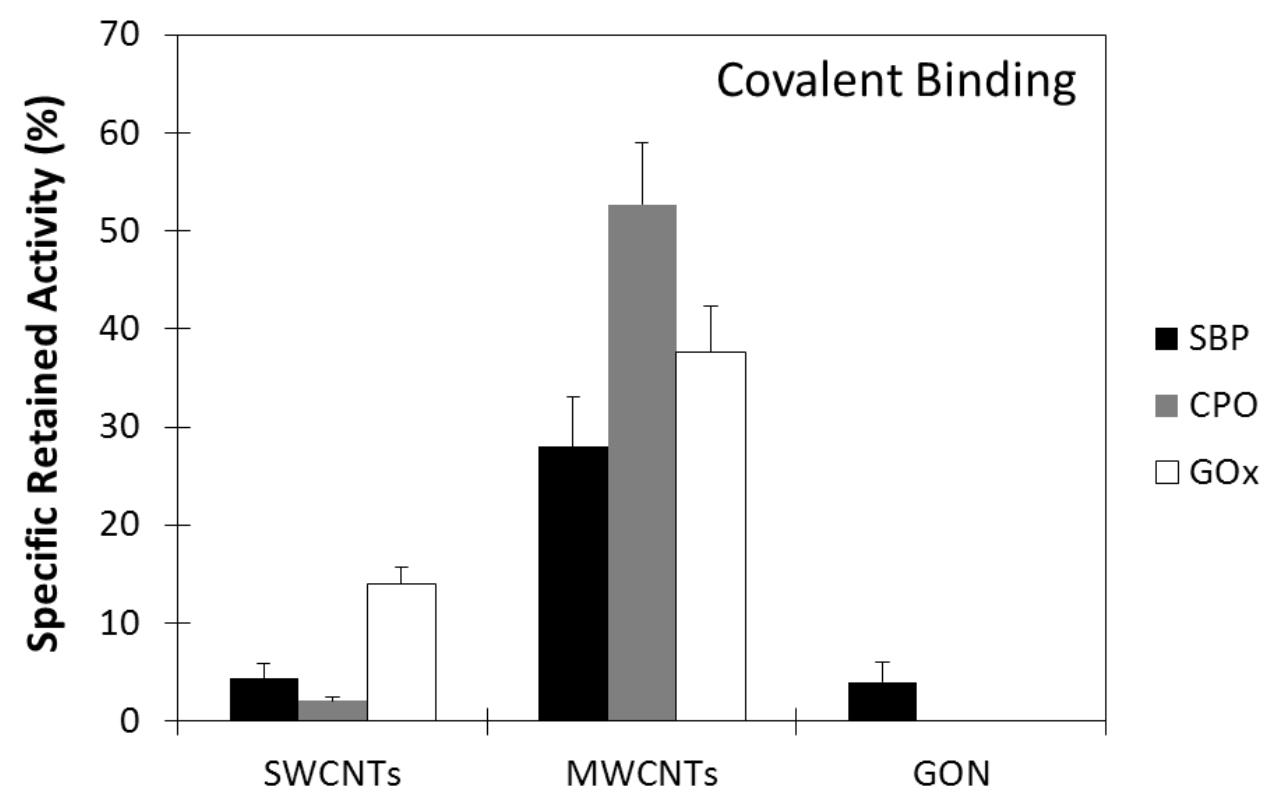




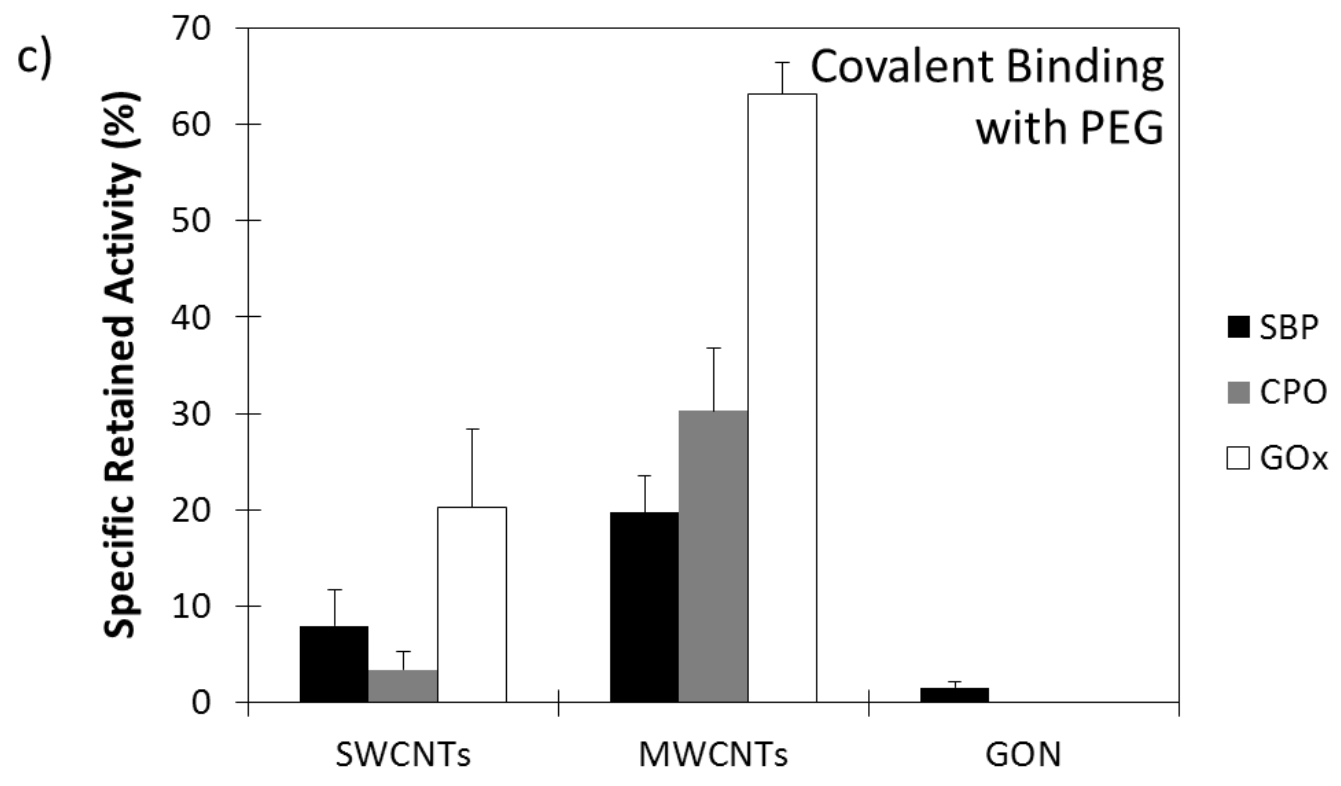

Figure 3: Specific retained activity comparison of $\mathrm{SBP}, \mathrm{CPO}$, and $\mathrm{GO}_{\mathrm{X}}$ immobilized onto SWCNTs, MWCNTs and GON via a) physical adsorption, b) covalent binding and c) covalent binding via PEG linker. Enzyme molecular weight as well as nanosupport diameter increase from left to right.

Our study found that enzymes bound to SWCNTs (0.8-1.2 nm diameter) retained lower percentages of activity compared to enzymes bound to MWCNTs (10-20 nm diameter) (Figure 3 $\mathrm{a}, \mathrm{b}$ and $\mathrm{c}$ ). For example, CPO physically bound to SWCNTs retained only around $2 \%$ of native activity whereas CPO physically bound to MWCNTs retained around $41 \%$ of native activity. This could be caused by an actual increase in protein-protein interaction between adjacent enzymes immobilized onto the same support ${ }^{54}$. The interactions caused by an abundance of enzyme immobilized onto the same support, potentially even forming a monolayer, could outweigh the benefits of enzyme denaturation and active site loss by using a support with a smaller diameter ${ }^{55}$. The much more dramatic decrease in rate of surface curvature observed with SBP immobilization onto GON (500-5,000 nm sheets) results in a specific retained activity also much lower than when MWCNTs were used, showing that the effect of surface curvature on enzyme denaturation and enzyme surface area lost to substrate interaction once again control the level of retained activity ${ }^{38}$.

Our studies, which could further be used to design an optimum enzyme immobilization strategy to maximize retained activity while enhancing stability, yield an optimum nanosupport diameter (MWCNTs, 10-20 nm). For example, when examining the physical immobilization of 
SBP onto the various nanosupports, MWCNTs yielded a specific retained activity of about $25 \%$, whereas SWCNTs and GON yielded activities of about 15 and 2\%, respectively. For covalent binding, this difference increased with MWCNTs maintaining about $28 \%$ and SWCNTs and GON only about $4 \%$ each.

The impact of various immobilization methods on specific retained activity was tested by attaching SBP, CPO and $\mathrm{GO}_{\mathrm{X}}$ to the CMATs using physical adsorption, covalent binding and covalent binding through a PEG linker (Figure $3 \mathrm{a}, \mathrm{b}$ and c, respectively). As can be seen in Figure 3, the most dramatic effect of immobilization method on retained activity occurs in the trials of $\mathrm{CPO}$ and $\mathrm{GO}_{\mathrm{X}}$ bound to MWCNTs. Specifically, CPO bound to MWCNTs physically, covalently and covalently with a PEG linker yielded retained activities of around 41, 53 and $30 \%$, respectively. $\mathrm{GO}_{\mathrm{X}}$ bound to MWCNTs physically, covalently and covalently with a PEG linker resulted in retained activities of around 10,38 and 63\%, respectively. Comparing physical to covalent immobilization, the retained activities of the CPO samples increased $12 \%$ whereas the $\mathrm{GO}_{\mathrm{X}}$ samples increased $28 \%$. This is attributed to non-specific binding of the enzyme at the hydrophobic walls of the MWCNTs. Both enzymes have an isoelectric point of around $4^{56,57}$, but the working $\mathrm{pH}$ of the $\mathrm{GO}_{\mathrm{X}}(\mathrm{PBS} \mathrm{pH}=7)$ trials is higher than that of $\mathrm{CPO}(\mathrm{CAB} \mathrm{pH}=4.8)$ meaning that the $\mathrm{GO}_{\mathrm{X}}$ is more negatively charged and thus has a higher affinity for hydrophobic surfaces. Therefore, more non-directed binding occurs in the physical immobilization trials of $\mathrm{GO}_{\mathrm{X}}$, which leads to extensive protein-protein and protein-nanosupport interactions ${ }^{9,38}$.

The covalent binding procedure helps to direct binding to the carboxyl functionalizations present on the surface of the CMATs ${ }^{50-52,55}$. As the CPO has a lower affinity for hydrophobic surfaces compared to that of $\mathrm{GO}_{\mathrm{X}}$, the transition to covalent binding from physical binding has less of an improvement on retained activity, although there is an improvement due to the more ordered binding mechanic. Further, covalent binding with the PEG linker is meant to bring the enzyme away from the surface of the nanosupport and thus more extensively reduce non-specific enzyme interaction ${ }^{9}{ }^{53}$. This effect is seen in the $25 \%$ increase in activity seen between $\mathrm{GO}_{\mathrm{X}}$ covalently bound and covalently bound with the linker. This significant increase further confirms the hindering of the enzyme at the nanosupports interface due to protein interaction as mentioned when comparing nanosupports physical and covalent binding. The increased size of $\mathrm{GO}_{\mathrm{X}}$ relative to SBP and CPO could also add to the extent of this effect. Alternately, CPO exhibited a $13 \%$ decrease in retained activity when covalent binding is compared to covalent binding with the 
PEG linker. It is possible that the size and structure of the CPO allows for interaction of the PEG spacer arm with the active site of the enzyme, thus hindering activity, as well as the increased mobility provided by the spacer arm causes agglomeration away from the nanointerface. These results show that variables such as immobilization technique affect enzyme-nanomaterial conjugates in an enzyme specific manner, which is in agreement with previous studies ${ }^{8,11}$.

\section{KINETICS OF THE ENZYME-CMATS CONJUGATES}

Kinetic parameters were evaluated for all enzyme-nanomaterial conjugate systems. Namely, $\mathrm{V}_{\max }$ and $\mathrm{K}_{\mathrm{m}}$ values were calculated using Lineweaver-Burk plots ${ }^{37}$, which allowed for the determination of $\mathrm{K}_{\mathrm{cat}}$ values. All kinetic parameters for the enzymatic systems, along with the kinetic parameters of free enzyme for comparison, are included in supporting information Tables S5, S6 and S7, respectively (Appendix 1). These kinetics data support the retained activity data previously discussed. For example, in the trials with SBP physically bound to various nanosupports, the trends follow those of the specific retained activity. Specifically, SBP physically adsorbed onto SWCNTs, MWCNTs and GON yielded $\mathrm{V}_{\max }$ values of $0.005,0.017$ and 0.003, respectively (Figure 4a). Similar to the immobilization onto various nanosupport comparisons, immobilization onto MWCNTs yielded a decrease of about $87 \%$ of native SBP whereas samples immobilized onto SWCNTs and GON resulted in $\mathrm{V}_{\max }$ decreases of 96 and 98\% when compared to the native enzyme, respectively. However, the $\mathrm{K}_{\mathrm{m}}$ values were on the same order of magnitude for all samples, indicating that there was no significant conformational change upon immobilization.

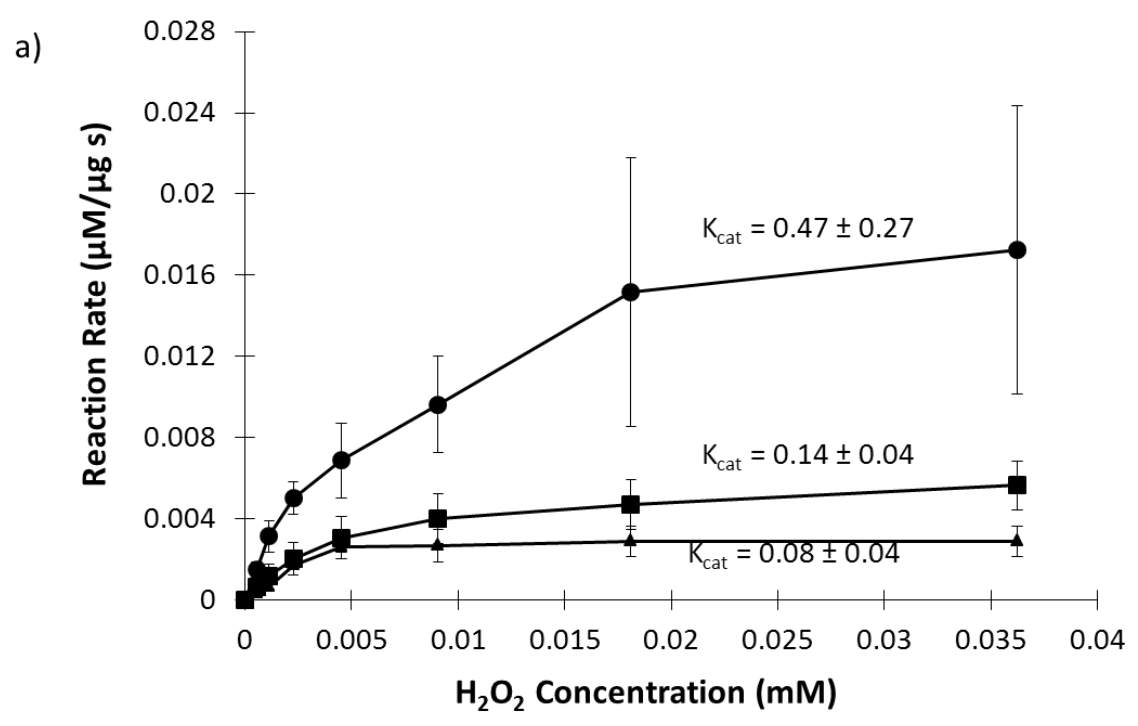



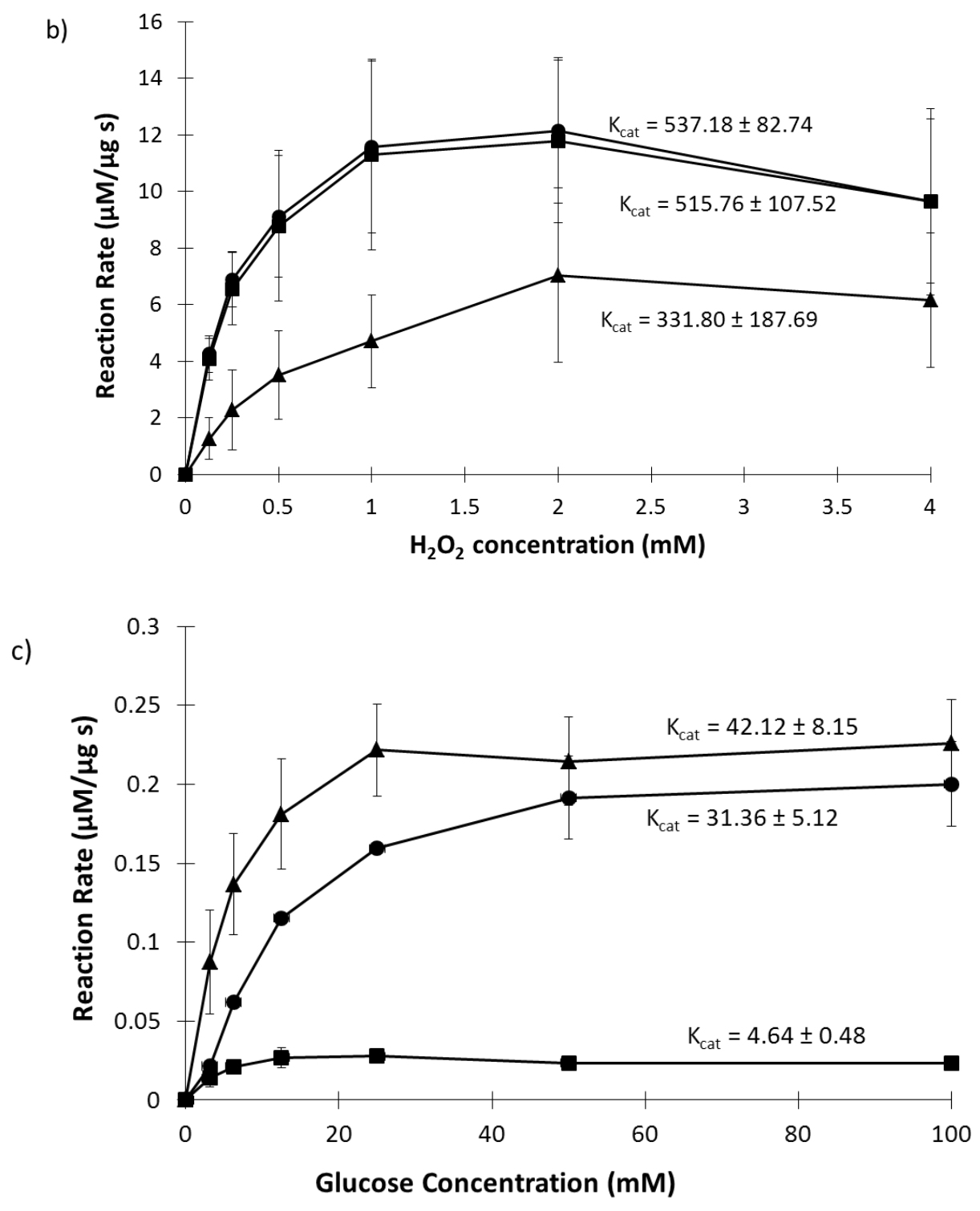

Figure 4: Michaelis-Menten kinetics data of a) SBP immobilized onto SWCNTs (filled square), MWCNTs (filled circle) and GON (filled triangle) via physical adsorption; b) CPO immobilized onto MWCNTs using physical adsorption (filled square), covalent binding (filled circle) and covalent binding through a PEG linker (filled triangle; and c) $\mathrm{GO}_{\mathrm{X}}$ immobilized onto MWCNTs using physical adsorption (filled square), covalent binding (filled circle) and covalent binding through a PEG linker (filled triangle).

Additionally, when comparing various immobilization methods, the kinetics reinforce specific retained activity observations. CPO bound to MWCNTs physically, covalently and covalently through a PEG linker yielded $\mathrm{V}_{\max }$ values of around 12, 13 and 8, respectively (Figure $4 b)$. This represents decreases of about 55, 53 and $71 \%$ from native enzyme, respectively, which show the effect of more directed binding discussed previously. 
The more dramatic effect of binding technique used was observed with the kinetics of the $\mathrm{GO}_{\mathrm{X}}$ samples. Specifically, $\mathrm{GO}_{\mathrm{X}}$ bound to MWCNTs physically, covalently and covalently through a PEG linker yielded $\mathrm{V}_{\max }$ values of around 0.029, 0.196 and 0.234, respectively (Figure 4c). These values correspond to decreases of around 94, 60 and 52\% from native enzyme, respectively. $\mathrm{Km}$ values for both $\mathrm{CPO}$ and $\mathrm{GO}_{\mathrm{X}}$ in these trials were on the same order of magnitude, respectively, confirming that no significant conformational change occurred upon immobilization.

\section{CONCLUSIONS}

We have studied the behavior of multiple enzymes immobilized onto nanosupports of varying characteristics using three immobilization techniques. The results show that the retained activity and kinetics of the immobilized enzyme are influenced by the properties of the support and the conditions of the immobilization being used, in an enzyme specific manner. Such an understanding of how to optimize the amount of enzyme activity and kinetic behavior retained upon immobilization is crucial for enzyme based applications such as biosensors and biofuel cells. 


\section{REFERENCES}

1. Mateo, C.; Palomo, J. M.; Fernandez-Lorente, G.; Guisan, J. M.; Fernandez-Lafuente, R., Improvement of enzyme activity, stability and selectivity via immobilization techniques. Enzyme Microb Tech 2007, 40, (6), 1451-1463.

2. Schmid, A.; Dordick, J. S.; Hauer, B.; Kiener, A.; Wubbolts, M.; Witholt, B., Industrial biocatalysis today and tomorrow. Nature 2001, 409, (6817), 258-268.

3. Cousins, C. M.; Allan, C. D., Sporicidal Properties of Some Halogens. J Appl Bacteriol 1967, 30, (1), 168-\&.

4. Taylor, G. R.; Butler, M., A Comparison of the Virucidal Properties of Chlorine, Chlorine Dioxide, Bromine Chloride and Iodine. J Hyg-Cambridge 1982, 89, (2), 321-\&.

5. Liu, Z. B.; Weis, R.; Glieder, A., Enzymes from higher eukaryotes for industrial biocatalysis. Food Technol Biotech 2004, 42, (4), 237-249.

6. Ibrahim, C. O., Development of applications of industrial enzymes from Malaysian indigenous microbial sources. Bioresource Technol 2008, 99, (11), 4572-4582.

7. Wandrey, C.; Liese, A.; Kihumbu, D., Industrial biocatalysis: Past, present, and future. Org Process Res Dev 2000, 4, (4), 286-290.

8. Garcia-Galan, C.; Berenguer-Murcia, A.; Fernandez-Lafuente, R.; Rodrigues, R. C., Potential of Different Enzyme Immobilization Strategies to Improve Enzyme Performance. Adv Synth Catal 2011, 353, (16), 2885-2904.

9. Dinu, C. Z.; Borkar, I. V.; Bale, S. S.; Campbell, A. S.; Kane, R. S.; Dordick, J. S., Perhydrolase-nanotube-paint sporicidal composites stabilized by intramolecular crosslinking. $J$ Mol Catal B-Enzym 2012, 75, 20-26.

10. Aburto, J.; Ayala, M.; Bustos-Jaimes, I.; Montiel, C.; Terres, E.; Dominguez, J. M.; Torres, E., Stability and catalytic properties of chloroperoxidase immobilized on SBA-16 mesoporous materials. Micropor Mesopor Mat 2005, 83, (1-3), 193-200.

11. Wang, L. A.; Xu, R.; Chen, Y. A.; Jiang, R. R., Activity and stability comparison of immobilized NADH oxidase on multi-walled carbon nanotubes, carbon nanospheres, and singlewalled carbon nanotubes. J Mol Catal B-Enzym 2011, 69, (3-4), 120-126.

12. Dinu, C. Z.; Zhu, G.; Bale, S. S.; Anand, G.; Reeder, P. J.; Sanford, K.; Whited, G.; Kane, R. S.; Dordick, J. S., Enzyme-Based Nanoscale Composites for Use as Active Decontamination Surfaces. Adv Funct Mater 2010, 20, (3), 392-398. 
13. Asuri, P.; Bale, S. S.; Pangule, R. C.; Shah, D. A.; Kane, R. S.; Dordick, J. S., Structure, function, and stability of enzymes covalently attached to single-walled carbon nanotubes. Langmuir 2007, 23, (24), 12318-12321.

14. Yang, M. L.; Wang, J.; Li, H. Q.; Zheng, J. G.; Wu, N. Q. N., A lactate electrochemical biosensor with a titanate nanotube as direct electron transfer promoter. Nanotechnology 2008, 19, (7).

15. Cui, Y. L.; Zhang, B.; Liu, B. Q.; Chen, H. F.; Chen, G. N.; Tang, D. P., Sensitive detection of hydrogen peroxide in foodstuff using an organic-inorganic hybrid multilayer-functionalized graphene biosensing platform. Microchim Acta 2011, 174, (1-2), 137-144.

16. Shi, J.; Claussen, J. C.; McLamore, E. S.; ul Haque, A.; Jaroch, D.; Diggs, A. R.; CalvoMarzal, P.; Rickus, J. L.; Porterfield, D. M., A comparative study of enzyme immobilization strategies for multi-walled carbon nanotube glucose biosensors. Nanotechnology 2011, 22, (35). 17. Zanon, N. C. M.; Oliveira, O. N.; Caseli, L., Immbolization of uricase enzyme in Langmuir and Langmuir-Blodgett films of fatty acids: Possible use as a uric acid sensor. J Colloid Interf Sci 2012, 373, 69-74.

18. Aubin-Tam, M. E.; Hamad-Schifferli, K., Structure and function of nanoparticle-protein conjugates. Biomed Mater 2008, 3, (3).

19. Kalantari, M.; Kazemeini, M.; Tabandeh, F.; Arpanaei, A., Lipase immobilisation on magnetic silica nanocomposite particles: effects of the silica structure on properties of the immobilised enzyme. J Mater Chem 2012, 22, (17), 8385-8393.

20. Grover, N.; Borkar, I. V.; Dinu, C. Z.; Kane, R. S.; Dordick, J. S., Laccase- and chloroperoxidase-nanotube paint composites with bactericidal and sporicidal activity. Enzyme Microb Tech 2012, 50, (6-7), 271-279.

21. Borkar, I. V.; Dinu, C. Z.; Zhu, G. Y.; Kane, R. S.; Dordick, J. S., Bionanoconjugate-Based Composites for Decontamination of Nerve Agents. Biotechnol Progr 2010, 26, (6), 1622-1628.

22. Song, Y. S.; Lee, J. H.; Kang, S. W.; Kim, S. W., Performance of beta-galactosidase pretreated with lactose to prevent activity loss during the enzyme immobilisation process. Food Chem 2010, 123, (1), 1-5.

23. Hirsh, S. L.; Bilek, M. M. M.; Nosworthy, N. J.; Kondyurin, A.; dos Remedios, C. G.; McKenzie, D. R., A Comparison of Covalent Immobilization and Physical Adsorption of a Cellulase Enzyme Mixture. Langmuir 2010, 26, (17), 14380-14388. 
24. Ivanova, E. P.; Wright, J. P.; Pham, D. K.; Brack, N.; Pigram, P.; Alekseeva, Y. V.; Demyashev, G. M.; Nicolau, D. V., A comparative study between the adsorption and covalent binding of human immunoglobulin and lysozyme on surface-modified poly(tert-butyl methacrylate). Biomed Mater 2006, 1, (1), 24-32.

25. Bayramoglu, G.; Kiralp, S.; Yilmaz, M.; Toppare, L.; Arica, M. Y., Covalent immobilization of chloroperoxidase onto magnetic beads: Catalytic properties and stability. Biochem Eng $J$ 2008, 38, (2), 180-188.

26. Besteman, K.; Lee, J. O.; Wiertz, F. G. M.; Heering, H. A.; Dekker, C., Enzyme-coated carbon nanotubes as single-molecule biosensors. Nano Lett 2003, 3, (6), 727-730.

27. Luckarift, H. R.; Spain, J. C.; Naik, R. R.; Stone, M. O., Enzyme immobilization in a biomimetic silica support. Nat Biotechnol 2004, 22, (2), 211-213.

28. Aina, V.; Ghigo, D.; Marchis, T.; Cerrato, G.; Laurenti, E.; Morterra, C.; Malavasi, G.; Lusvardi, G.; Menabue, L.; Bergandi, L., Novel bio-conjugate materials: soybean peroxidase immobilized on bioactive glasses containing Au nanoparticles. J Mater Chem 2011, 21, (29), 10970-10981.

29. Shi, L. H.; Liu, X. Q.; Niu, W. X.; Li, H. J.; Han, S.; Chen, J.; Xu, G. B., Hydrogen peroxide biosensor based on direct electrochemistry of soybean Peroxidase immobilized on single-walled carbon nanohorn modified electrode. Biosens Bioelectron 2009, 24, (5), 1159-1163.

30. Henriksen, A.; Mirza, O.; Indiani, C.; Teilum, K.; Smulevich, G.; Welinder, K. G.; Gajhede, M., Structure of soybean seed coat peroxidase: A plant peroxidase with unusual stability and haem-apoprotein interactions. Protein Sci 2001, 10, (1), 108-115.

31. Sung, W. J.; Bae, Y. H., A glucose oxidase electrode based on polypyrrole with polyanion/PEG/enzyme conjugate dopant. Biosens Bioelectron 2003, 18, (10), 1231-1239.

32. Singh, K.; Singh, B. P.; Chauhan, R.; Basu, T., Fabrication of amperometric bienzymatic glucose biosensor based on MWCNT tube and polypyrrole multilayered nanocomposite. J Appl Polym Sci 2012, 125, E235-E246.

33. Zargoosh, K.; Chaichi, M. J.; Shamsipur, M.; Hossienkhani, S.; Asghari, S.; Qandalee, M., Highly sensitive glucose biosensor based on the effective immobilization of glucose oxidase/carbon-nanotube and gold nanoparticle in nafion film and peroxyoxalate chemiluminescence reaction of a new fluorophore. Talanta 2012, 93, 37-43. 
34. Dong, C. B.; Campell, A. S.; Eldawud, R.; Perhinschi, G.; Rojanasakul, Y.; Dinu, C. Z., Effects of acid treatment on structure, properties and biocompatibility of carbon nanotubes. Appl Surf Sci 2013, 264, 261-268.

35. Dong, C.; Kashon, M. L.; Lowry, D.; Dordick, J. S.; Reynolds, S. H.; Rojanasakul, Y.; Sargent, L. M.; Dinu, C. Z., Exposure to Carbon Nanotubes Leads to Changes in the Cellular Biomechanics. Advanced healthcare materials 2013.

36. Chendong Zhang, S. L., Wei Chen Activity of Catalase Adsorbed to Carbon Nanotubes: Effects of Carbon Nanotube Surface Properties. Talanta 2013.

37. Al-Haque, N.; Santacoloma, P. A.; Neto, W.; Tufvesson, P.; Gani, R.; Woodley, J. M., A robust methodology for kinetic model parameter estimation for biocatalytic reactions. Biotechnol Progr 2012, 28, (5), 1186-1196.

38. Asuri, P.; Bale, S. S.; Karajanagi, S. S.; Kane, R. S., The protein-nanomaterial interface. current opinion in biotechnology 2006, 17, (6), 562-568.

39. Sassolas, A.; Blum, L. J.; Leca-Bouvier, B. D., Immobilization strategies to develop enzymatic biosensors. Biotechnol Adv 2012, 30, (3), 489-511.

40. Tu, X. M.; Zhao, Y. J.; Luo, S. L.; Luo, X. B.; Feng, L., Direct electrochemical sensing of glucose using glucose oxidase immobilized on functionalized carbon nanotubes via a novel metal chelate-based affinity method. Microchim Acta 2012, 177, (1-2), 159-166.

41. Sakata, M.; Funatsu, A.; Sonoda, S.; Ogata, T.; Taniguchi, T.; Matsumoto, Y., Immobilization of Trypsin on Graphene Oxide Nanosheets for Increased Proteolytic Stability. Chem Lett 2012, 41, (12), 1625-1627.

42. Liu, Y.; Yu, D. S.; Zeng, C.; Miao, Z. C.; Dai, L. M., Biocompatible Graphene Oxide-Based Glucose Biosensors. Langmuir 2010, 26, (9), 6158-6160.

43. Zhang, Y.; Zhang, J. Y.; Huang, X. L.; Zhou, X. J.; Wu, H. X.; Guo, S. W., Assembly of Graphene Oxide-Enzyme Conjugates through Hydrophobic Interaction. Small 2012, 8, (1), 154159.

44. Wepasnick, K. A.; Smith, B. A.; Schrote, K. E.; Wilson, H. K.; Diegelmann, S. R.; Fairbrother, D. H., Surface and structural characterization of multi-walled carbon nanotubes following different oxidative treatments. Carbon 2011, 49, (1), 24-36. 
45. Kulshrestha, N.; Misra, A.; Hazra, K. S.; Roy, S.; Bajpai, R.; Mohapatra, D. R.; Misra, D. S., Healing of Broken Multiwalled Carbon Nanotubes Using Very Low Energy Electrons in SEM: A Route Toward Complete Recovery. Acs Nano 2011, 5, (3), 1724-1730.

46. Stobinski, L.; Lesiak, B.; Kover, L.; Toth, J.; Biniak, S.; Trykowski, G.; Judek, J., Multiwall carbon nanotubes purification and oxidation by nitric acid studied by the FTIR and electron spectroscopy methods. J Alloy Compd 2010, 501, (1), 77-84.

47. Guo, H. L.; Wang, X. F.; Qian, Q. Y.; Wang, F. B.; Xia, X. H., A Green Approach to the Synthesis of Graphene Nanosheets. Acs Nano 2009, 3, (9), 2653-2659.

48. Khoshnevisan, K.; Bordbar, A. K.; Zare, D.; Davoodi, D.; Noruzi, M.; Barkhi, M.;

Tabatabaei, M., Immobilization of cellulase enzyme on superparamagnetic nanoparticles and determination of its activity and stability. Chem Eng J 2011, 171, (2), 669-673.

49. Nikolic, M. P.; Srdic, V. V.; Antov, M. G., Immobilization of lipase into mesoporous silica particles by physical adsorption. Biocatal Biotransfor 2009, 27, (4), 254-262.

50. Gao, Y.; Kyratzis, I., Covalent Immobilization of Proteins on Carbon Nanotubes Using the Cross-Linker 1-Ethyl-3-(3-dimethylaminopropyl)carbodiimide-a Critical Assessment.

Bioconjugate Chem 2008, 19, (10), 1945-1950.

51. Zhu, H. G.; Srivastava, R.; Brown, J. Q.; McShane, M. J., Combined physical and chemical immobilization of glucose oxidase in alginate microspheres improves stability of encapsulation and activity. Bioconjugate Chem 2005, 16, (6), 1451-1458.

52. Rollett, A.; Schroeder, M.; Schneider, K. P.; Fischer, R.; Kaufmann, F.; Schoftner, R.;

Guebitz, G. M., Covalent immobilisation of protease and laccase substrates onto siloxanes.

Chemosphere 2010, 80, (8), 922-928.

53. Manta, C.; Ferraz, N.; Betancor, L.; Antunes, G.; Batista-Viera, F.; Carlsson, J.; Caldwell, K., Polyethylene glycol as a spacer for solid-phase enzyme immobilization. Enzyme Microb Tech 2003, 33, (7), 890-898.

54. Asuri, P.; Karajanagi, S. S.; Yang, H. C.; Yim, T. J.; Kane, R. S.; Dordick, J. S., Increasing protein stability through control of the nanoscale environment. Langmuir 2006, 22, (13), 58335836.

55. Prlainovic, N. Z.; Bezbradica, D. I.; Knezevic-Jugovic, Z. D.; Marinkovic, A. D.; Uskokovic, P. S.; Mijin, D. Z., Immobilization of Enzymes onto Carbon Nanotubes. Hem Ind 2011, 65, (4), 423-430. 
56. Aoun, S.; Chebli, C.; Baloulene, M., Noncovalent immobilization of chloroperoxidase onto talc: Catalytic properties of a new biocatalyst. Enzyme Microb Tech 1998, 23, (6), 380-385.

57. Kusakari, A.; Izumi, M.; Ohnuki, H., Preparation of an enzymatic glucose sensor based on hybrid organic-inorganic Langmuir-Blodgett films: Adsorption of glucose oxidase into positively charged molecular layers. Colloid Surface A 2008, 321, (1-3), 47-51. 


\section{APPENDIX 1}

a)
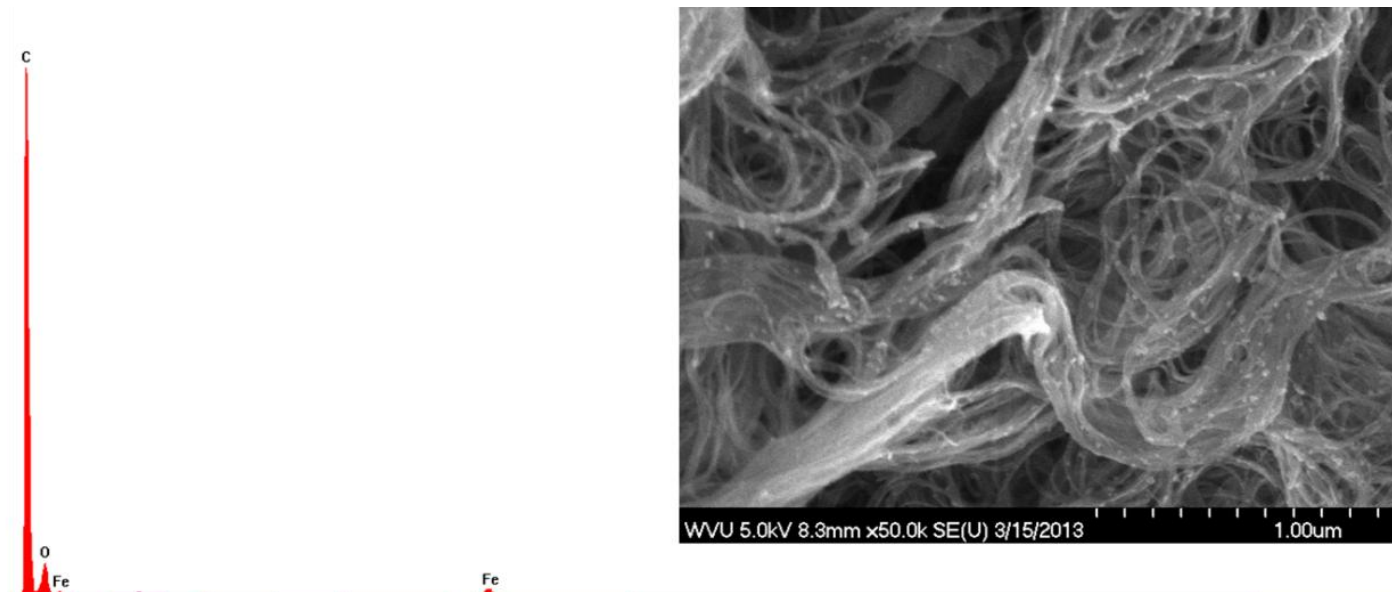

ite
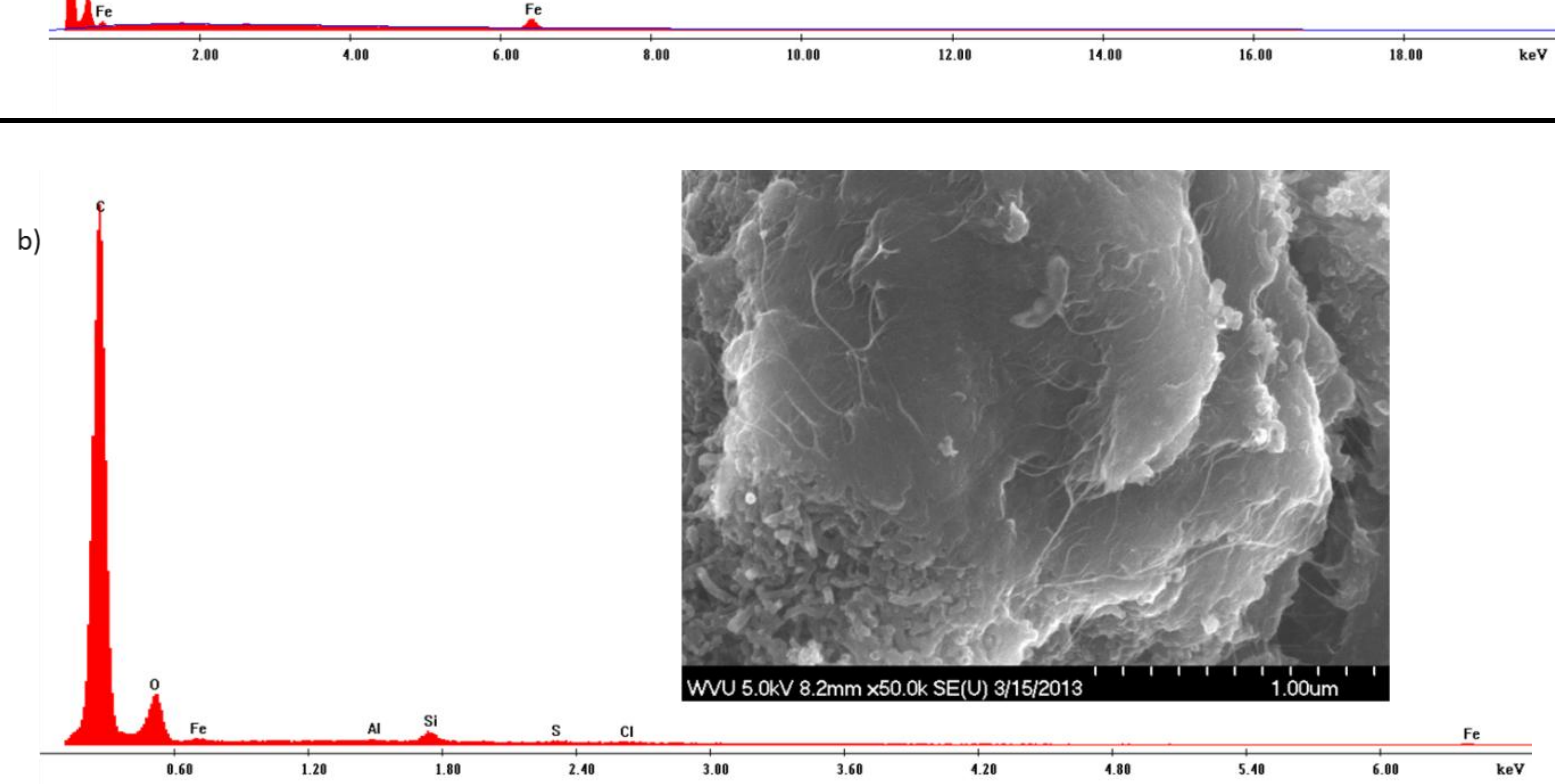

c)

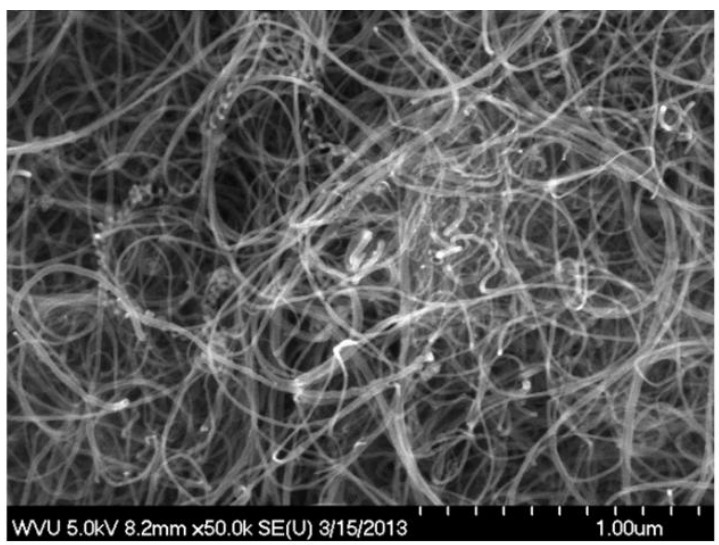

WU 5.0kV $8.2 \mathrm{~mm} \times 50.0 \mathrm{k} \mathrm{SE}(\mathrm{U}) 3 / 15 / 2013$ 

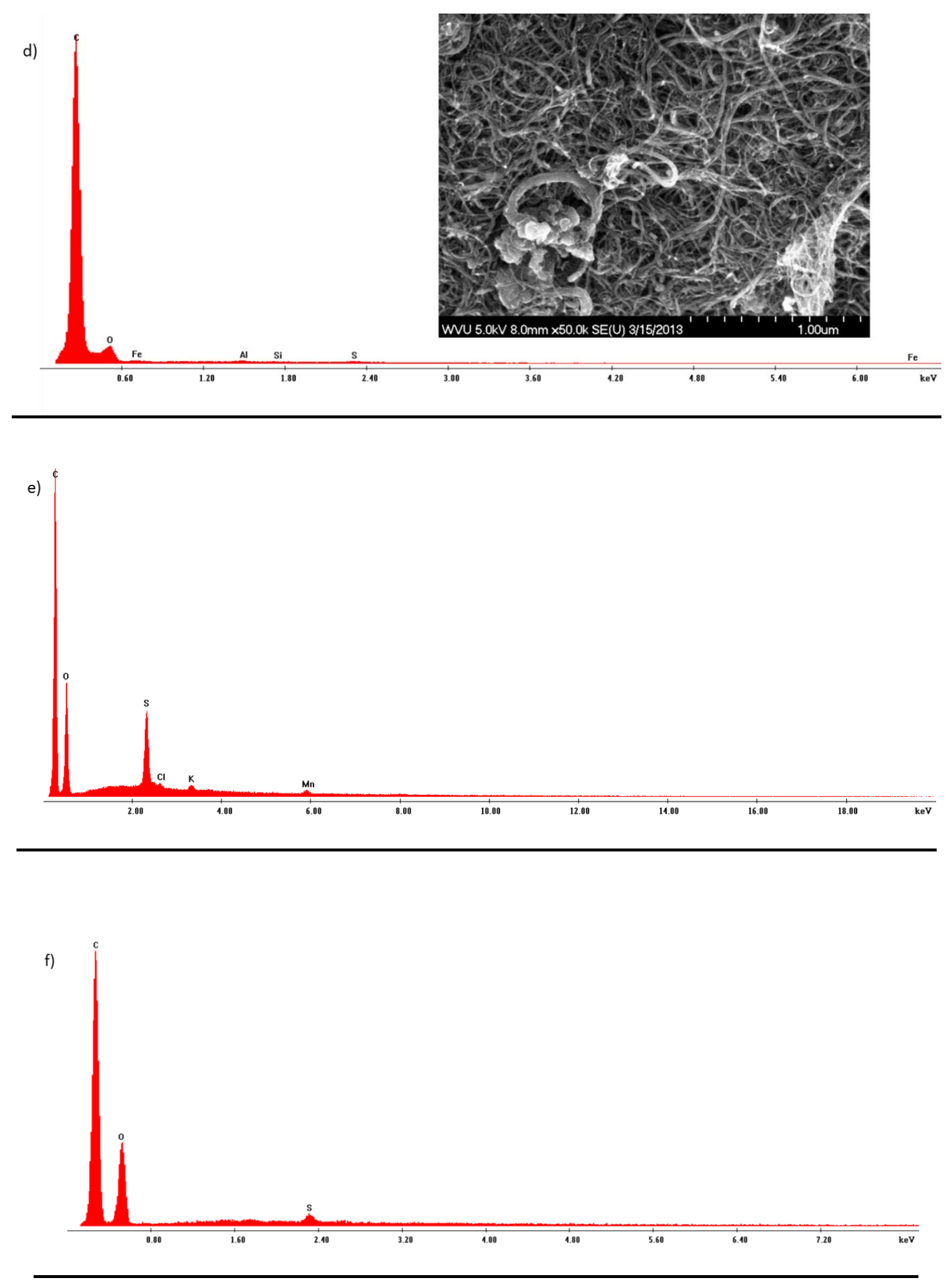
Figure S1: EDX data and SEM image of a) pristine SWCNTs, b) acid functionalized SWCNTs, c) pristine MWCNTs, d) acid functionalized MWCNTs; and EDX data of e) pristine GON and f) acid functionalized GON. SEM images of GON could not be obtained due to sample charging.

Table S1: Nanosupport Solubility

\begin{tabular}{|c|c|c|c|}
\hline \multirow{2}{*}{ Nanosupport } & \multicolumn{3}{|c|}{ Solubility (mg/mL) } \\
\cline { 2 - 4 } & CAB (50 mM, pH 4.8) & DI Water (pH 6.25) & PBS (100 mM, pH 7) \\
\hline $\begin{array}{c}\text { Pristine } \\
\text { SWCNTs }\end{array}$ & 0.06 & 0.06 & 0.13 \\
\hline $\begin{array}{c}\text { Acid Treated } \\
\text { SWCNTs }\end{array}$ & 0.50 & 0.56 & 0.63 \\
\hline $\begin{array}{c}\text { Pristine } \\
\text { MWCNTs }\end{array}$ & 0.06 & 0.13 & 0.13 \\
\hline $\begin{array}{c}\text { Acid Treated } \\
\text { MWCNTs }\end{array}$ & 0.56 & 0.88 & 0.50 \\
\hline $\begin{array}{c}\text { Pristine } \\
\text { GON }\end{array}$ & 0.13 & 0.31 & 0.81 \\
\hline $\begin{array}{c}\text { Acid Treated } \\
\text { GON }\end{array}$ & 1.75 & 2.01 & 1.13 \\
\hline
\end{tabular}

Table S2: Physical Adsorption Loading and Activity Data

\begin{tabular}{|c|c|c|}
\hline Enzyme-Nanosupport & $\begin{array}{c}\text { Loading } \\
\text { (mg enzyme / } \\
\text { mg nanosupport) }\end{array}$ & $\begin{array}{c}\text { Specific Retained } \\
\text { Activity (\%) }\end{array}$ \\
\hline SBP-SWCNTs & $0.19 \pm 0.03$ & $14.81 \pm 6.77$ \\
\hline CPO-SWCNTs & $0.09 \pm 0.02$ & $1.49 \pm 0.16$ \\
\hline GO $_{\mathrm{X}-S W C N T s}$ & $0.17 \pm 0.03$ & $1.99 \pm 0.45$ \\
\hline SBP-MWCNTs & $0.15 \pm 0.05$ & $25.28 \pm 4.04$ \\
\hline CPO-MWCNTs & $0.10 \pm 0.02$ & $41.36 \pm 6.65$ \\
\hline GOX-MWCNTs & $0.24 \pm 0.02$ & $9.89 \pm 3.30$ \\
\hline SBP-GON & $0.27 \pm 0.06$ & $1.71 \pm 0.77$ \\
\hline
\end{tabular}


Table S3: Covalent Binding Loading and Activity Data

\begin{tabular}{|c|c|c|}
\hline Enzyme-Nanosupport & $\begin{array}{c}\text { Loading } \\
\text { (mg enzyme / } \\
\text { mg nanosupport) }\end{array}$ & $\begin{array}{c}\text { Specific Retained } \\
\text { Activity (\%) }\end{array}$ \\
\hline SBP-SWCNTs & $0.08 \pm 0.02$ & $4.38 \pm 1.49$ \\
\hline CPO-SWCNTs & $0.06 \pm 0.01$ & $2.06 \pm 0.35$ \\
\hline GO $_{\mathrm{X}-\text { SWCNTs }}$ & $0.25 \pm 0.03$ & $14.04 \pm 1.69$ \\
\hline SBP-MWCNTs & $0.24 \pm 0.10$ & $28.01 \pm 5.01$ \\
\hline CPO-MWCNTs & $0.07 \pm 0.02$ & $52.70 \pm 6.26$ \\
\hline GOX-MWCNTs & $0.25 \pm 0.02$ & $37.67 \pm 4.70$ \\
\hline SBP-GON & $0.16 \pm 0.04$ & $4.03 \pm 1.98$ \\
\hline
\end{tabular}

Table S4: Covalent Binding through PEG Linker Loading and Activity Data

\begin{tabular}{|c|c|c|}
\hline Enzyme-Nanosupport & $\begin{array}{c}\text { Loading } \\
\text { (mg enzyme / } \\
\text { mg nanosupport) }\end{array}$ & $\begin{array}{c}\text { Specific Retained } \\
\text { Activity (\%) }\end{array}$ \\
\hline SBP-SWCNTs & $0.23 \pm 0.05$ & $7.99 \pm 3.73$ \\
\hline CPO-SWCNTs & $0.04 \pm 0.02$ & $3.46 \pm 1.81$ \\
\hline GOX-SWCNTs & $0.06 \pm 0.02$ & $20.32 \pm 8.08$ \\
\hline SBP-MWCNTs & $0.10 \pm 0.03$ & $19.70 \pm 3.82$ \\
\hline CPO-MWCNTs & $0.18 \pm 0.05$ & $30.26 \pm 6.59$ \\
\hline GOX-MWCNTs & $0.04 \pm 0.01$ & $63.06 \pm 3.37$ \\
\hline SBP-GON & $0.16 \pm 0.02$ & $1.59 \pm 0.60$ \\
\hline
\end{tabular}


Table S5: Soybean Peroxidase Michaelis-Menten Kinetics

\begin{tabular}{|c|c|c|c|}
\hline Nanosupport & $\begin{array}{c}\text { Maximum } \\
\text { Production Rate } \\
\left(\mu \mathrm{M} \mu \mathrm{g}^{-1} \mathrm{~s}^{-1}\right)\end{array}$ & $\mathrm{K}_{\mathrm{m}}\left(\mu \mathrm{M} \mathrm{H}_{2} \mathrm{O}_{2}\right)$ & $\mathrm{K}_{\text {cat }}\left(\mathrm{s}^{-1}\right)$ \\
\hline Free SBP & $0.128 \pm 0.042$ & $1.9 \pm 0.8$ & $3.53 \pm 1.64$ \\
\hline $\begin{array}{l}\text { MWCNTs } \\
\text { (Physical) } \\
\end{array}$ & $0.017 \pm 0.007$ & $7.2 \pm 2.3$ & $0.47 \pm 0.27$ \\
\hline $\begin{array}{l}\text { MWCNTs } \\
\text { (Covalent) }\end{array}$ & $0.011 \pm 0.004$ & $1.6 \pm 0.4$ & $0.30 \pm 0.16$ \\
\hline $\begin{array}{c}\text { MWCNTs } \\
\text { (Covalent with PEG) }\end{array}$ & $0.008 \pm 0.003$ & $2.9 \pm 0.4$ & $0.22 \pm 0.12$ \\
\hline $\begin{array}{c}\text { SWCNT } \\
\text { (Physical) } \\
\end{array}$ & $0.005 \pm 0.001$ & $3.7 \pm 1.0$ & $0.14 \pm 0.04$ \\
\hline $\begin{array}{c}\text { SWCNTs } \\
\text { (Covalent) } \\
\end{array}$ & $0.012 \pm 0.003$ & $3.7 \pm 1.1$ & $0.33 \pm 0.12$ \\
\hline $\begin{array}{c}\text { SWCNTs } \\
\text { (Covalent with PEG) }\end{array}$ & $0.022 \pm 0.011$ & $3.4 \pm 1.7$ & $0.61 \pm 0.43$ \\
\hline $\begin{array}{c}\text { GON } \\
(\text { Physical }) \\
\end{array}$ & $0.003 \pm 0.001$ & $1.4 \pm 1.0$ & $0.08 \pm 0.04$ \\
\hline $\begin{array}{c}\text { GON } \\
\text { (Covalent) }\end{array}$ & $0.005 \pm 0.001$ & $2.6 \pm 0.3$ & $0.14 \pm 0.04$ \\
\hline $\begin{array}{c}\text { GON } \\
\text { (Covalent with PEG) }\end{array}$ & $0.002 \pm 0.001$ & $2.8 \pm 2.7$ & $0.03 \pm 0.04$ \\
\hline
\end{tabular}

Table S6: Chloroperoxidase Michaelis-Menten Kinetics

\begin{tabular}{|c|c|c|c|}
\hline Nanosupport & $\begin{array}{l}\text { Maximum } \\
\text { Production Rate } \\
\left(\mu \mathrm{M} \mu \mathrm{g}^{-1} \mathrm{~s}^{-1}\right)\end{array}$ & $\mathrm{K}_{\mathrm{m}}\left(\mu \mathrm{M} \mathrm{H}_{2} \mathrm{O}_{2}\right)$ & $\mathrm{K}_{\text {cat }}\left(\mathrm{s}^{-1}\right)$ \\
\hline Free CPO & $27.14 \pm 2.60$ & $480 \pm 70$ & $1,139.88 \pm 109.20$ \\
\hline $\begin{array}{l}\text { MWCNTs } \\
\text { (Physical) }\end{array}$ & $12.28 \pm 2.56$ & $340 \pm 70$ & $515.76 \pm 107.52$ \\
\hline $\begin{array}{l}\text { MWCNTs } \\
\text { (Covalent) }\end{array}$ & $12.79 \pm 1.97$ & $530 \pm 60$ & $537.18 \pm 82.74$ \\
\hline $\begin{array}{c}\text { MWCNTs } \\
\text { (Covalent with PEG) }\end{array}$ & $7.90 \pm 3.16$ & $550 \pm 130$ & $331.8 \pm 187.69$ \\
\hline $\begin{array}{c}\text { SWCNT } \\
\text { (Physical) } \\
\end{array}$ & $0.42 \pm 0.12$ & $240 \pm 40$ & $17.64 \pm 7.13$ \\
\hline $\begin{array}{l}\text { SWCNTs } \\
\text { (Covalent) }\end{array}$ & $0.56 \pm 0.10$ & $140 \pm 30$ & $23.52 \pm 5.94$ \\
\hline $\begin{array}{c}\text { SWCNTs } \\
\text { (Covalent with PEG) }\end{array}$ & $0.94 \pm 0.49$ & $130 \pm 20$ & $39.48 \pm 19.10$ \\
\hline
\end{tabular}


Table S7: Glucose Oxidase Michaelis-Menten Kinetics

\begin{tabular}{|c|c|c|c|}
\hline Nanosupport & $\begin{array}{c}\text { Maximum } \\
\text { Production Rate } \\
\left(\mu \mathrm{M} \mu \mathrm{g}^{-1} \mathrm{~s}^{-1}\right)\end{array}$ & $\begin{array}{c}\mathrm{K}_{\mathrm{m}} \\
(\mu \mathrm{M} \text { glucose })\end{array}$ & $\mathrm{K}_{\mathrm{cat}}\left(\mathrm{s}^{-1}\right)$ \\
\hline Free GOX & $0.488 \pm 0.040$ & $2,600 \pm 500$ & $78.08 \pm 6.40$ \\
\hline $\begin{array}{c}\text { MWCNTs } \\
\text { (Physical) }\end{array}$ & $0.029 \pm 0.003$ & $1,800 \pm 800$ & $4.64 \pm 0.48$ \\
\hline $\begin{array}{c}\text { MWCNTs } \\
\text { (Covalent) }\end{array}$ & $0.196 \pm 0.032$ & $3,200 \pm 700$ & $31.36 \pm 5.12$ \\
\hline $\begin{array}{c}\text { MWCNTs } \\
(\text { Covalent with PEG) }\end{array}$ & $0.234 \pm 0.032$ & $2,600 \pm 700$ & $42.12 \pm 8.15$ \\
\hline $\begin{array}{c}\text { SWCNT } \\
\text { (Physical) }\end{array}$ & $0.043 \pm 0.010$ & $2,300 \pm 600$ & $7.74 \pm 2.55$ \\
\hline $\begin{array}{c}\text { SWCNTs } \\
\text { (Covalent) }\end{array}$ & $0.067 \pm 0.005$ & $1,000 \pm 100$ & $12.06 \pm 1.27$ \\
\hline $\begin{array}{c}\text { SWCNTs } \\
\text { (Covalent with PEG) }\end{array}$ & $0.099 \pm 0.039$ & $2,300 \pm 500$ & $17.82 \pm 9.93$ \\
\hline
\end{tabular}




\title{
CHAPTER 3
}

\section{BIONANO ENGINEERED HYBRIDS FOR MICROBIAL DECONTAMINANT PRODUCTION}

\begin{abstract}
Current methods for microbial decontamination are corrosive and/or toxic and can cause collateral damage to goods and people. Herein a non-toxic, non-corrosive and easily deployable enzyme-nanosupport hybrid system was developed for in situ generation of hypochlorous acid $(\mathrm{HOCl})$, a strong decontaminant. Chloroperoxidase working enzyme was immobilized onto two different nanosupports (i.e., a photocatalyst and a carbon-based nanomaterial) and the enzyme loading and activity at the nanosupport interfaces, as well as its potential to generate $\mathrm{HOCl}$ was evaluated. The enzyme-photocatalyst hybrid system showed negligible capability of $\mathrm{HOCl}$ generation under UV light irradiation. In contrast, the enzyme-carbon-based hybrid system exhibited strong capability of $\mathrm{HOCl}$ generation, which further has the potential to be employed for decontamination of bacteria and spores.
\end{abstract}

\section{INTRODUCTION}

With the high demand for disinfection of contaminated surfaces in hospital settings ${ }^{1-6}$ and for removal of chemical or biological warfare agents in military scenarios ${ }^{7-10}$, it is of great importance to develop coatings that are fast in decontaminating, readily deployable, and userand environmentally benign. Conventionally used microbial decontamination agents such as glutaraldehyde, alcohols, ammonium compounds or halides (i.e. chlorine or iodine) are required in high concentrations and can be harmful to both the environment and humans ${ }^{11-14}$. Further, they cannot be incorporated into coatings and are usually deployed after contamination has occurred ${ }^{7}$, 8 . Thus, there is an increased interest in developing microbial decontamination coatings that can decontaminate during contamination or immediately upon contamination, while protecting personnel and infrastructure and allowing for self-cleaning ${ }^{15}, 16$. Ideally, such coatings should also allow decontamination of large areas as well as decontamination of sensitive substrates ${ }^{17}$.

Current methods to produce coatings with decontamination capabilities rely mainly on encapsulating oxide-based photocatalysts such as titanium dioxide ${ }^{18-20}$ zinc $_{\text {oxide }}^{21,22}$, or silver 
nanoparticles $^{23,24}$ into composites to produce reactive oxygen species (i.e. hydrogen peroxide $\left(\mathrm{H}_{2} \mathrm{O}_{2}\right)$, superoxide radical, etc.). However, such coatings have shown limitations with regard to the photocatalyst leaching out ${ }^{25}$, or the $\mathrm{H}_{2} \mathrm{O}_{2}$ decontaminant not being strong enough to allow decontamination of more resilient pathogens such as spores ${ }^{23,26-28}$. Recently, our group has shown that enzyme-carbon nanomaterial-based conjugates entrapped into polymer or paint-based coatings can generate potent decontamination agents such as hypochlorous or peracetic acid ${ }^{29,30}$. Using such coatings, decontamination was achieved upon addition of specific enzyme substrates, e.g. for perhydrolase S54V (AcT)-carbon nanotubes conjugates encapsulated into latex-based paints, peracetic acid was produced in the presence of propylene glycol diacetate and $\mathrm{H}_{2} \mathrm{O}_{2}$ as substrates, yielding the efficient decontamination of both E. coli and B. cereus ${ }^{31}$. Similarly, laccase- or chloroperoxidase-carbon nanotubes conjugates encapsulated into paints allowed decontamination of $E$. coli and $S$. aureus, with laccase showing further decontamination capability against $B$. cereus and $B$. anthracis, after the addition of the respective substrates for each enzyme (i.e., $\mathrm{H}_{2} \mathrm{O}_{2}$ for chloroperoxidase and $\mathrm{I}^{-}$anions for laccase) ${ }^{30}$. In these studies the carbon nanotubes enhanced enzyme stability, while their high surface area to volume aspect ratios allowed for high enzyme loadings and thus retention of the enzyme-nanosupport conjugates into the coatings ${ }^{31-35}$.

We now aim to advance towards creating a self-decontaminating enzyme-nanosupport hybrid system to be incorporated into coatings and allow in situ generation of hypochlorous acid $(\mathrm{HOCl}) . \mathrm{HOCl}$ has a wide spectrum of activity against a variety of pathogens such as spores and bacteria $^{30,31,36}$. Specifically, we are employing two different strategies to allow the working enzyme chloroperoxidase (CPO) to use $\mathrm{H}_{2} \mathrm{O}_{2}$ produced at nanosupport interface to convert $\left(\mathrm{Cl}^{-}\right)$ into $\mathrm{HOCl}$. The $\mathrm{H}_{2} \mathrm{O}_{2}$ is produced either by a titanium dioxide $\left(\mathrm{TiO}_{2}-\mathrm{NBs}\right)$ or by a multi-walled carbon nanotube (MWCNT-COOH) modified nanosupport through a photocatalytic or an enzymatic chain reaction, respectively. We characterized the biocatalysts at the nanosupport interface and compared the two strategies in terms of $\mathrm{HOCl}$ generation rate, as well as the retained CPO activity upon immobilization. Such strategies could provide viable means for the next generation of self-sustainable coatings with enhanced stability and activity to be used for surface-decontamination of model bacteria or spores. 


\section{EXPERIMENTAL}

\section{SYNTHESIS OF TITANIUM DIOXIDE NANOBELTS (TIO 2 -NBS)}

Pristine anatase titanium dioxide nanosupports were synthesized by hydrothermal processing. Specifically, $1.2 \mathrm{~g}$ of anatase titanium dioxide nanoparticles (Alfa Aesar, USA) were added to 85 $\mathrm{mL}$ of $10 \mathrm{M}$ sodium hydroxide (Sigma, USA) aqueous solution. The mixture was vigorously stirred for $1 \mathrm{~h}$ at room temperature and transferred to a $100 \mathrm{~mL}$ Teflon-lined stainless steel autoclave and heated at $190^{\circ} \mathrm{C}$ for $24 \mathrm{~h}$. The resulting white, fluffy powder was collected and washed with copious amounts of DI water and 0.1 M hydrochloric acid (Fisher Scientific, USA) until the $\mathrm{pH}$ of the washing solution was less than 7 . The powder was further dried overnight at $80^{\circ} \mathrm{C}$ and heated in a quartz tube furnace at $700^{\circ} \mathrm{C}$ for $30 \mathrm{~min}$ with a ramp rate of $1{ }^{\circ} \mathrm{C} / \mathrm{min}$ to obtain pristine single-crystalline anatase titanium dioxide nanosupports $\left(\mathrm{TiO}_{2}\right)$. The pristine nanosupports were subsequently functionalized with 3-triethoxysilylpropyl succinic anhydride (TESPSA, Fisher Scientific, USA) to lead to titanium dioxide nanosupports with carboxyl group functionalities ( $\mathrm{TiO}_{2}-\mathrm{NBs}$ ). For this, TESPSA was added to a toluene solution (Fisher Scientific, USA) of titanium dioxide nanosupports and stirred at room temperature for $24 \mathrm{~h}$. Then, the mixture was centrifuged and washed with methanol (Fisher Scientific, USA) to remove excess TESPSA. The $\mathrm{TiO}_{2}-\mathrm{NBs}$ were dried overnight at $80^{\circ} \mathrm{C}$, and stored at room temperature until use.

\section{MULTI-WALLED CARBON NANOTUBE (MWCNTS) FUNCTIONALIZATION}

Commercial multi-walled carbon nanotubes (MWCNTs, 95\% purity, 10-20 nm in diameter, Nanolab Inc., PD15L5-20, USA) were acid functionalized to obtain carboxyl group

functionalities $^{37,38}$. Briefly, $100 \mathrm{mg}$ of MWCNTs were added to a $60 \mathrm{~mL}$ mixture of 3:1 (V/V) sulfuric (Fisher Scientific, 96.4\%, USA) and nitric (Fisher Scientific, 69.6\%, USA) acids and sonicated in an ice bath at a constant temperature of approximately $23^{\circ} \mathrm{C}$ for $6 \mathrm{~h}$. The MWCNTsacids mixture was then diluted, filtered, and washed extensively with DI water to remove any catalysts or residues. Thus, carboxyl functionalized MWCNTs (MWCNT-COOH) were dried under vacuum and stored at room temperature until use $\mathrm{e}^{29,37,38}$.

\section{NANOSUPPORT CHARACTERIZATION}

Samples $\left(\mathrm{TiO}_{2}\right.$ and $\mathrm{TiO}_{2}-\mathrm{NBs}$ or MWCNTs and MWCNT-COOH) were characterized using Scanning Electron Microscopy (SEM) and Atomic Force Microscopy (AFM). Briefly, samples 
( $1 \mathrm{mg} / \mathrm{mL}$ in DI water) were deposited on silica wafers, dried under vacuum, and then examined using a Hitachi S-4700 Field Emission Scanning Electron Microscope with a S-4700 detector combining secondary (SE) and backscattered (BSE) electron detection (in a single unit). For AFM, a Si tip (Asylum Research, 50-90 KHz AC240TS, USA) was employed to investigate the length of pristine and carboxyl functionalized MWCNTs. The samples $(0.1 \mathrm{mg} / \mathrm{mL}$ in DI water) were mounted on a mica substrate $(9.5 \mathrm{~mm}$ diameter, 0.15- $0.21 \mathrm{~mm}$ thickness, Electron Microscopy Sciences, USA) and dried under vacuum. Scans were performed in air and images of $10 \mu \mathrm{m} \times 10 \mu \mathrm{m}$ were obtained. At least 30 individual nanotubes from different images were measured to acquire the average length distribution.

$\mathrm{TiO}_{2}$-NBs were further characterized using Fourier Transform Infrared Spectroscopy (FTIR) in order to confirm carboxyl functionalization. FTIR data were collected in transmission mode using $\mathrm{KBr}$ pellet method on a Thermo Nicolet Instrument (USA).

Raman spectroscopy (Renishaw InVia Raman Spectrometer, CL532-100, 100 mW, USA) was used to investigate the chemical structure and properties of MWCNTs (both pristine and carboxyl functionalized MWCNTs). Samples $(1 \mathrm{mg} / \mathrm{mL}$ ) were deposited on glass slides (Fisher, USA) and irradiated through a 20x microscope objective using an argon ion $\left(\mathrm{Ar}^{+}\right)$laser beam performing at $514.5 \mathrm{~nm}$ and having a spot size of $<0.01 \mathrm{~mm}^{2}$. Low laser energy (i.e., $<0.5 \mathrm{mV}$ ) and short exposure time $(\sim 10 \mathrm{sec})$ were set to prevent unexpected heating effects of the sample. Successive scans ranging from 100 to $3200 \mathrm{~cm}^{-1}$ were acquired.

\section{ENZYME IMMOBILIZATION}

Three different strategies were employed for enzyme immobilization onto the nanosupports (either $\mathrm{TiO}_{2}-\mathrm{NBs}$ or MWCNTs-COOH). First, covalent attachment of the enzyme was carried out as previously demonstrated ${ }^{29}$. Generally, $2 \mathrm{mg}$ of nanosupport was dispersed in $2 \mathrm{~mL}$ of 2 (N-morpholino)ethanesulfonic acid sodium salt (MES) buffer (50 mM, pH 4.7, Fisher, USA) containing $160 \mathrm{mM}$ 1-ethyl-3-[3-dimethylaminopropyl]carbodiimide hydrochloride (EDC, Acros Organics, USA) and $80 \mathrm{mM}$ N-hydroxysuccinimide (NHS, Pierce, USA) by brief sonication. After 15 min incubation with shaking at $200 \mathrm{rpm}$ and at room temperature, the nanosupports were filtered and washed thoroughly with MES buffer. Subsequently, the nanosupports were redispersed in a $0.5 \mathrm{mg} / \mathrm{mL}$ solution of either chloroperoxidase (CPO, Bioresearch, USA) or glucose oxidase $\left(\mathrm{GO}_{\mathrm{X}}\right.$, Sigma, USA). After $3 \mathrm{~h}$ incubation at room temperature with shaking at 
$200 \mathrm{rpm}$, the nanosupport-enzyme conjugates were filtered and washed thoroughly with citric acid buffer (CAB, $50 \mathrm{mM}, \mathrm{pH}$ 4.8, Sigma, USA) for CPO or sodium phosphate buffer (PBS, 100 $\mathrm{mM}, \mathrm{pH} 7$, Sigma, USA) for $\mathrm{GO}_{\mathrm{X}}$.

Secondly, covalent binding through a PEG linker was carried out in an effort to bring the enzyme away from the nanosupport ${ }^{29}$. Briefly, the nanosupports were first activated using EDC/NHS chemistry as previously described, and then incubated for $3 \mathrm{~h}$ in $5 \mathrm{~mL}$ of $1 \mathrm{mg} / \mathrm{ml}$ amino-dPEG ${ }_{8}$-acid in PBS (3.2 nm length, Quanta Biodesign, USA). After $3 \mathrm{~h}$, the PEGnanosupports were extensively washed with PBS and redispersed in the EDC/NHS=160 mM/80 $\mathrm{mM}$ solution for $15 \mathrm{~min}$ at $200 \mathrm{rpm}$ and room temperature. Upon activation the nanosupports were filtered, washed thoroughly with MES and redispersed in $0.5 \mathrm{mg} / \mathrm{mL}$ solution of enzyme (either $\mathrm{CPO}$ or $\mathrm{GO}_{\mathrm{X}}$ ) for covalent binding as previously described ${ }^{29}$.

Thirdly, for the $\mathrm{CPO}$ and $\mathrm{GO}_{\mathrm{X}}$ immobilization onto the same nanosupport, a combined binding strategy was used. Specifically, one enzyme was first covalently attached to MWCNTs$\mathrm{COOH}$ as previously described ${ }^{29}$. The conjugates were then extensively washed with the necessary buffer and subsequently used for the physical attachment of the second enzyme (initial concentration of $0.5 \mathrm{mg} / \mathrm{mL}$ of either $\mathrm{CPO}$ or $\mathrm{GO}_{\mathrm{X}}$ were used during both immobilizations). Physical adsorption was performed for $2 \mathrm{~h}$ at room temperature, with shaking at $200 \mathrm{rpm}$.

After the incubation, the conjugates were extensively washed with the designated buffer. When immobilization was completed, the supernatants and first two washes of each immobilization strategy were isolated to determine enzyme loading.

\section{ENZYME LOADING}

The concentration of enzyme in the washing solutions or in the supernatants was determined using standard bicinchonic acid (BCA) assay ${ }^{29,31,39,40}$. Specifically, a working reagent was first prepared by mixing 50 parts of reagent A with 1 part of reagent B (reagents were provided with the BCA Assay kit, Pierce, USA). $50 \mu \mathrm{L}$ of each washing or supernatant solution was then added to $1 \mathrm{~mL}$ of the working reagent and incubated in a water bath at $37^{\circ} \mathrm{C}$ for $30 \mathrm{~min}$. The absorbance of each sample was monitored at $562 \mathrm{~nm}$ using an UV-Vis spectrophotometer (Thermo Scientific EVO300, USA). Standard calibration curves were prepared using the corresponding native enzyme and serial dilutions (from $1 \mathrm{mg} / \mathrm{mL}$ to $0.03 \mathrm{mg} / \mathrm{mL}$ ). The enzyme loadings onto the nanosupports were estimated as the difference between the initial amount of 
enzyme added in the immobilization process, and the total amount of enzyme washed out in the isolated supernatants and two washes. Results are reported as mean \pm standard deviation with at least six trials for each statistic.

\section{ENZYME ACTIVITY}

The enzyme activity upon immobilization was spectrophotometrically assessed using an $\mathrm{UV}-\mathrm{Vis}$ spectrophotometer. The immobilized enzyme activity is reported as the specific retained activity relative to the same amount of free enzyme in solution. For measuring CPO activity, the conversion of monochlorodimedon (MCD) to dichlorodimedon in the presence of $\mathrm{H}_{2} \mathrm{O}_{2}$ and sodium chloride $(\mathrm{NaCl})$ was monitored at $278 \mathrm{~nm}$ for $2 \mathrm{~min}$. The reaction mixture contained 50 $\mathrm{mM}$ CAB, $100 \mathrm{mM} \mathrm{NaCl}, 0.1 \mathrm{mM} \mathrm{MCD}, 1 \mathrm{mM} \mathrm{H} \mathrm{O}_{2}$, and $20 \mu \mathrm{L}$ of CPO sample (all reagents were purchased from Sigma, USA unless otherwise specified). For $\mathrm{GO}_{\mathrm{X}}$, the production of $\mathrm{H}_{2} \mathrm{O}_{2}$ was monitored by the oxidation of $0.25 \mathrm{mg} / \mathrm{mL}$ ABTS by soybean peroxidase (SBP, Bioresearch, USA) in excess at $412 \mathrm{~nm}$ for $2 \mathrm{~min}$. The reaction mixture contained $50 \mathrm{mM}$ PBS, $62.5 \mathrm{mM}$ glucose (Acros Scientific, USA), $0.05 \mathrm{mg} / \mathrm{ml} \mathrm{SBP,} 12.5 \mu \mathrm{g} / \mathrm{mL}$ ABTS, and $50 \mu \mathrm{L}$ of $\mathrm{GO}_{\mathrm{X}}$ sample. For the multiple enzyme system, the CPO activity assay used glucose $(62.5 \mathrm{mM}$ final concentration) instead of free $\mathrm{H}_{2} \mathrm{O}_{2}$. The rate of $\mathrm{HOCl}$ generation was calculated using the extinction coefficient of CPO at $278 \mathrm{~nm}\left(\varepsilon=12.2 \mathrm{mM}^{-1} \mathrm{~cm}^{-135}\right)$. The rate of $\mathrm{HOCl}$ generation is proportional to the rate of MCD conversion which is calculated knowing the amount of enzyme in the sample being tested, the enzyme extinction coefficient and the beam path length in the spectrophotometer $\left(1 \mathrm{~cm}\right.$ in this setup ${ }^{41}$. Results are reported as mean \pm standard deviation with at least six trials for each statistic.

\section{DETERMINATION OF TIO 2 -NB PHOTOCATALYTIC CAPABILITIES}

Hydrogen peroxide $\left(\mathrm{H}_{2} \mathrm{O}_{2}\right)$ generated by the $\mathrm{TiO}_{2}-\mathrm{NBs}$ was quantified upon incubation of the nanosupport in DI water, under UV light for various time periods, and using two independent assays, i.e. the chloroperoxidase activity assay (CPO, Bioresearch, USA), and the Amplex® Red Hydrogen Peroxide/Peroxidase Assay Kit (Invitrogen, USA). For the CPO assay, $5 \mathrm{~mL}$ of 1 $\mathrm{mg} / \mathrm{mL} \mathrm{TiO}_{2}-\mathrm{NBs}$ was incubated under UV-A $(\lambda=316-400 \mathrm{~nm})$ or UV-C $(\lambda=235-280 \mathrm{~nm})$ irradiation, in ice for 10, 30 or $60 \mathrm{~min}$. The solution was immediately filtered, and the filtrate containing $\mathrm{H}_{2} \mathrm{O}_{2}$ generated was used as the $\mathrm{H}_{2} \mathrm{O}_{2}$ source for the previously described CPO 
activity assay. Specifically, $20 \mu \mathrm{L}$ of the filtrate was added to a solution containing $50 \mathrm{mM} \mathrm{CAB}$, $100 \mathrm{mM} \mathrm{NaCl}, 0.1 \mathrm{mM} \mathrm{MCD}$, and $0.007 \mathrm{mg} / \mathrm{mL}$ of free CPO (average concentration in CPO activity assay used for immobilized enzyme) (final volume $1 \mathrm{~mL}$ ) in a quartz cuvette, and the absorbance was monitored at $278 \mathrm{~nm}$ for $5 \mathrm{~min}$ on a UV-vis spectrophotometer. For the Amplex ${ }^{\circledR}$ Red Hydrogen Peroxide Assay $500 \mu \mathrm{L}$ of filtrate was added to $500 \mu \mathrm{L}$ of Amplex ${ }^{\circledR}$ Red working solution containing $100 \mu \mathrm{M}$ Amplex® Red reagent and $0.2 \mathrm{U} / \mathrm{mL}$ horseradish peroxidase. All reagents are included in assay kit. After $30 \mathrm{~min}$ incubation at room temperature, the absorbance of the solution was measured at $560 \mathrm{~nm}$ and compared to a calibration curve of known $\mathrm{H}_{2} \mathrm{O}_{2}$ concentrations.

\section{CPO-BASED-TIO 2 =NB CONJUGATES FOR HOCL GENERATION}

The $\mathrm{HOCl}$ generation rate of $\mathrm{CPO}-\mathrm{TiO}_{2}-\mathrm{NB}$ conjugates was determined based on the $\mathrm{CPO}$ activity assay previously described with modifications. Specifically, a $2 \mathrm{~mL}$ sample of $1 \mathrm{mg} / \mathrm{mL}$ CPO-TiO ${ }_{2}$-NB conjugates was incubated under UV-A $(\lambda=316-400 \mathrm{~nm})$ or UV-C $(\lambda=235-280$ $\mathrm{nm}$ ) in ice for 10, 30 or 60 min. Immediately following incubation, $40 \mu \mathrm{L}$ of the solution was added to a reaction mixture consisting of $50 \mathrm{mM} \mathrm{CAB}, 100 \mathrm{mM} \mathrm{NaCl}$ and $0.1 \mathrm{mM} \mathrm{MCD}$ (final volume $1 \mathrm{~mL}$ ) in a quartz cuvette, and the absorbance was monitored at $278 \mathrm{~nm}$ for 5 min on a $\mathrm{UV}$-vis spectrophotometer. The rate of $\mathrm{HOCl}$ generation was calculated using the extinction coefficient of CPO at $278 \mathrm{~nm}\left(\varepsilon=12.2 \mathrm{mM}^{-1} \mathrm{~cm}^{-1}\right)^{35}$ as previously described.

\section{ENZYME KINETIC PARAMETERS DETERMINATION}

The kinetic parameters, $\mathrm{K}_{\mathrm{m}}$ and $\mathrm{V}_{\max }$ values, of the free and immobilized $\mathrm{CPO}$ and $\mathrm{GO}_{\mathrm{X}}$ (onto both nanosupports, i.e. $\mathrm{TiO}_{2}-\mathrm{NB}$ and $\mathrm{MWCNT}-\mathrm{COOH}$ ) were determined by measuring the initial rates of reaction in the $\mathrm{CPO}$ or $\mathrm{GO}_{\mathrm{X}}$ activity assays previously described, with $\mathrm{H}_{2} \mathrm{O}_{2}(0-4$ $\mathrm{mM}$ final concentration) or glucose $(0-100 \mathrm{mM}$ final concentration), respectively, as the substrate. The $\mathrm{K}_{\mathrm{m}}$ and $\mathrm{V}_{\max }$ values for the free and immobilized enzymes were calculated using Lineweaver-Burk plots by using the initial rate of the enzymatic reaction data:

$\frac{1}{v}=\frac{k_{m}}{v_{\max }[S]}+\frac{1}{v_{\max }}$, where [S] is the concentration of the substrate, $\mathrm{V}$ and $\mathrm{V}_{\max }$ represent the initial and maximum rates of reaction, respectively, and $\mathrm{K}_{\mathrm{m}}$ is the Michaelis-Menten constant. 


\section{STORAGE STABILITY OF ENZYME-BASED CONJUGATES}

The storage stability of the free and CPO-carbon nanomaterial-based conjugates was investigated by measuring the activities of the conjugates stored at 4 or $23{ }^{\circ} \mathrm{C}$ for a 4 week period. The activities were measured after 1, 2 and 4 weeks using the previously reported MCD assay.

\section{RESULTS AND DISCUSSION}

We are focusing our efforts on creating an active enzyme-nanosupport hybrid system to be incorporated into coatings and allow in situ generation of hypochlorous acid ( $\mathrm{HOCl})$. Our hypothesis is that the working enzyme, chloroperoxidase (CPO), immobilized onto nanosupports can use $\mathrm{H}_{2} \mathrm{O}_{2}$ produced at the nanosupport interface to convert $\left(\mathrm{Cl}^{-}\right)$into $\mathrm{HOCl}$. $\mathrm{HOCl}$ has a wide spectrum of activity against a variety of pathogens from spores to bacteria ${ }^{30,31,36}$. Two different strategies were proposed and evaluated to determine the efficiency and yield of $\mathrm{HOCl}$ generation. Further, the enzyme kinetics and stability were assessed.

\section{STRATEGY 1: ENZYME-PHOTOCATALYST HYBRID SYSTEMS FOR IN SITU GENERATION OF HOCL}

In the first strategy, we hypothesized that titanium dioxide can produce $\mathrm{H}_{2} \mathrm{O}_{2}$ as the substrate to be used by CPO to for the conversion of $\left(\mathrm{Cl}^{-}\right)$into $\mathrm{HOCl}$. Titanium dioxide is a widely studied photocatalyst that produces reactive oxygen species from water when excited under UV light ${ }^{42-}$ 44 . Even though the photocatalyst has been extensively studied for the decontamination of a wide variety of water contaminants ${ }^{43,45}$ as well as contaminants in air ${ }^{46}$, to our knowledge there are no previous studies that attempted using the titanium dioxide as a scaffold nanosupport to generate $\mathrm{H}_{2} \mathrm{O}_{2}$ for further enzyme kinetics.

The scaffold nanosupport was produced from pristine anatase titanium dioxide via hydrothermal processing ${ }^{47}$. Specifically, pristine anatase titanium dioxide nanosupports were carboxyl functionalized using 3-triethoxysilylpropyl succinic anhydride to allow the formation of titanium dioxide nanobelts or $\mathrm{TiO}_{2}-\mathrm{NBs}$ (Figure 1a). Carboxyl functionalities were confirmed using Fourier Transform Infrared Spectroscopy (FTIR; Figure 1b). A large peak was identified at $1731 \mathrm{~cm}^{-1}$ confirming the presence of the $\mathrm{C}=\mathrm{O}$ bond onto the $\mathrm{TiO}_{2}-\mathrm{NBs}^{48}$. 
a)

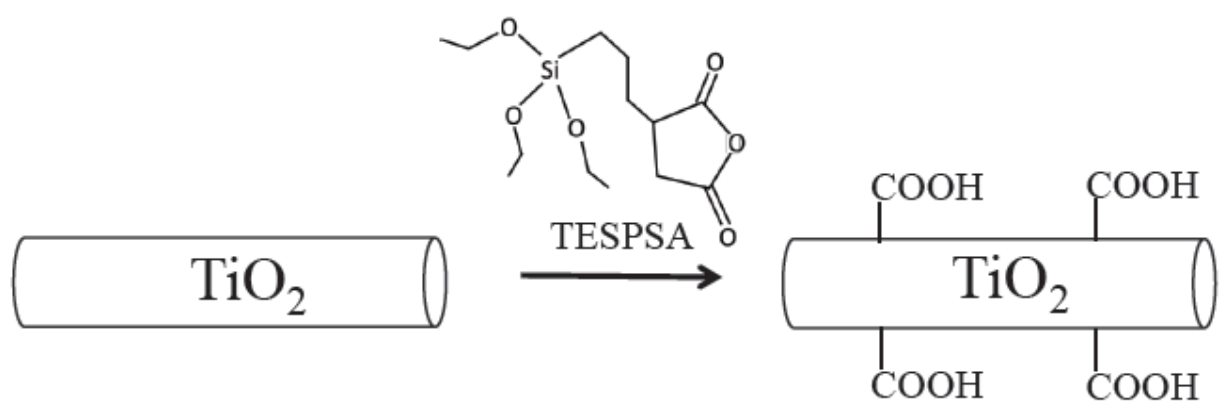

b)

c)
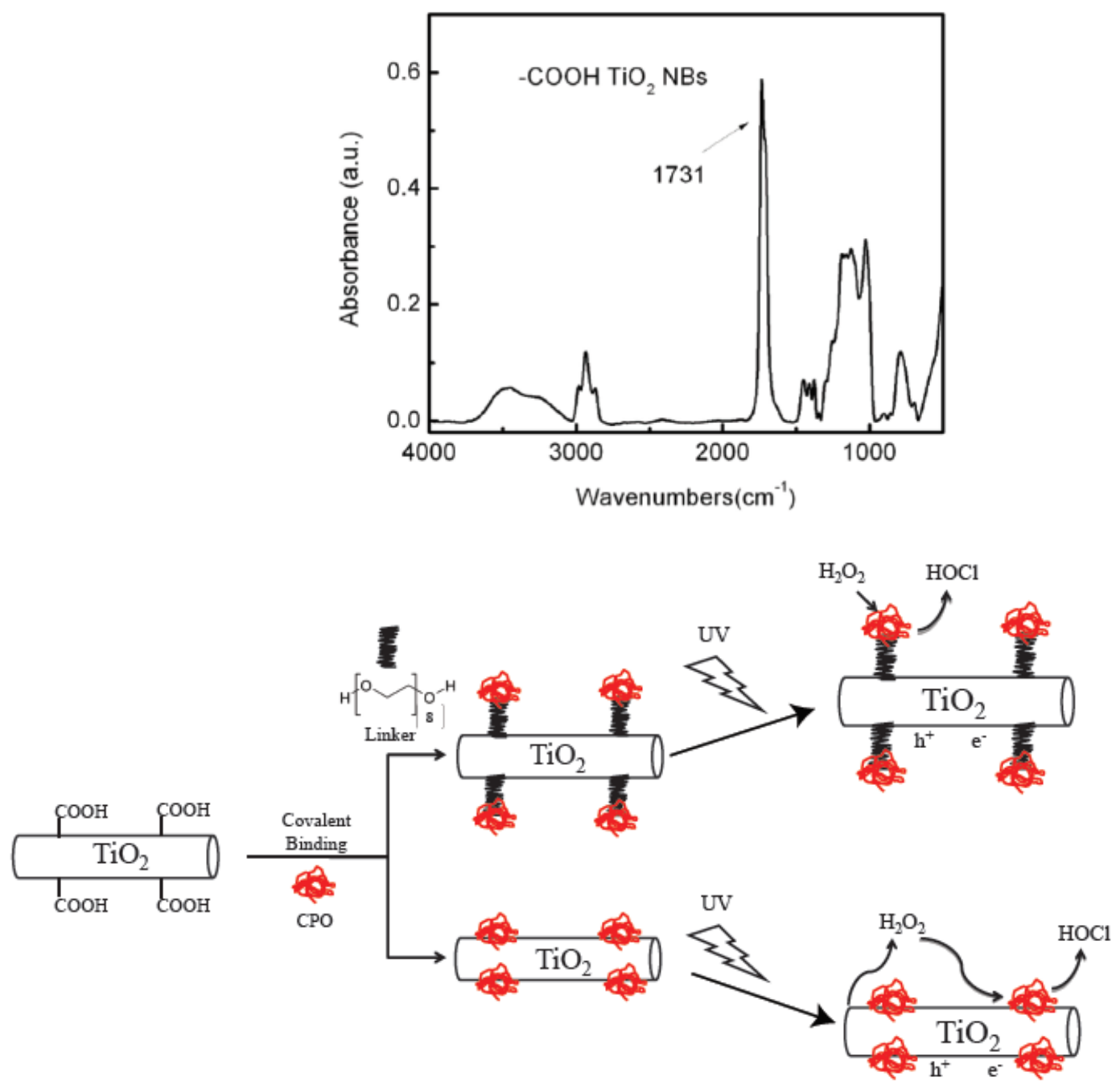

Figure 1: a) Functionalization of photocatalyst pristine titanium dioxide results in the formation of carboxyl functionalized nanobelts or $\mathrm{TiO}_{2}-\mathrm{NBs}$. b) FTIR spectrum of $\mathrm{TiO}_{2}-\mathrm{NBs}$ reveals the presence of the carboxyl peak at $1731 \mathrm{~cm}^{-1}$, confirming - $\mathrm{COOH}$ functionalization. c) $\mathrm{CPO}$ enzyme immobilization onto $\mathrm{TiO}_{2}-\mathrm{NBs}$ with and without the use of a PEG linker. The CPO$\mathrm{TiO}_{2}-\mathrm{NBs}$-based conjugates generate $\mathrm{HOCl}$ under $\mathrm{UV}$ irradiation. 
To determine whether the carboxyl functionalization changed the nanosupport morphology, pristine anatase titanium dioxide and $\mathrm{TiO}_{2}$-NBs nanosupports were investigated using Scanning Electron Microscopy (SEM). SEM images of the nanosupports before and after carboxyl functionalization are shown in Figure S1 (Appendix 2). The nanosupports were found to be 60$300 \mathrm{~nm}$ wide and several micrometers in length. No significant changes were identified in the $\mathrm{TiO}_{2}$-NBs morphology or length distribution upon carboxyl functionalization.

In order to generate enzyme-hybrid systems, we used the $\mathrm{TiO}_{2}$-NBs as scaffolds for the covalent immobilization of CPO enzyme through EDC/NHS chemistry ${ }^{49}, 50$ or EDC/NHS chemistry with a PEG spacer ${ }^{29}$ (Figure 1c). The PEG spacer was highly hydrophilic, with a length of $3.2 \mathrm{~nm}$; previous studies have shown that such a spacer has little or no chemical effect on enzyme immobilization and allows for improved solubility of the nanosupport ${ }^{51}$. The CPO$\mathrm{TiO}_{2}$-NBs and CPO-PEG-TiO ${ }_{2}$-NBs conjugates showed enzyme loadings of $0.10 \pm 0.03$ and 0.04 $\pm 0.02 \mathrm{mg}$ enzyme $/ \mathrm{mg}$ nanosupport, respectively, which represented $20 \%$ and $8 \%$ of the amount of protein that was offered, respectively (Table 1).

Table 1: Characterization of $\mathrm{CPO}-\mathrm{TiO}_{2}$ hybrid system for in situ generation of $\mathrm{HOCl}$.

\begin{tabular}{|c|c|c|}
\hline Parameter & ${\mathrm{CPO}-\mathrm{TiO}_{2}}^{\text {LPO-PEG-TiO }}$ \\
\hline $\begin{array}{c}\text { Loading } \\
\text { (mg protein/mg nanosupport) }\end{array}$ & $0.10 \pm 0.03$ & $0.04 \pm 0.02$ \\
\hline $\begin{array}{c}\text { Loading function of enzyme } \\
\text { offered (\%) }\end{array}$ & 20 & 8 \\
\hline $\begin{array}{c}\text { Specific retained } \\
\text { activity relative to free enzyme } \\
(\%)\end{array}$ & $0.30 \pm 0.13$ & $12.00 \pm 1.63$ \\
\hline $\begin{array}{c}\mathrm{V}_{\max } \\
\left(\mu \mathrm{M} \mathrm{g}^{-1} \mathrm{~s}^{-1}\right)\end{array}$ & $0.54 \pm 0.11$ & $4.64 \pm 0.87$ \\
\hline $\begin{array}{c}\mathrm{K}_{\mathrm{m}} \\
\left(\mu \mathrm{M} \mathrm{H}_{2} \mathrm{O}_{2}\right)\end{array}$ & $270 \pm 80$ & $490 \pm 70$ \\
\hline $\begin{array}{c}\mathrm{K}_{\text {cat }} \\
\left(\mathrm{s}^{-1}\right)\end{array}$ & $22.68 \pm 4.62$ & $194.88 \pm 36.54$ \\
\hline$\eta$ & 0.02 & 0.17 \\
\hline
\end{tabular}


The activity of the CPO immobilized at the $\mathrm{TiO}_{2}-\mathrm{NBs}$ interface was evaluated using the colorimetric reaction showing the conversion of monochlorodimedon to dichlorodimedon in the presence of $\mathrm{H}_{2} \mathrm{O}_{2}$. The CPO- $\mathrm{TiO}_{2}-\mathrm{NBs}$ conjugates retained about $0.3 \%$, while CPO-PEG-TiO $2^{-}$ NBs conjugates retained about $12 \%$ activity when compared to the activity of the same amount of free CPO in solution (Table 1). The low activity observed for $\mathrm{CPO}-\mathrm{TiO}_{2}-\mathrm{NBs}$ is attributed to the interface reactions that take place at the $\mathrm{TiO}_{2}-\mathrm{NBs}$ nanosupport surface. Specifically, previous studies have shown that nanosupports with lower curvature favor enzyme-enzyme interactions and non-specific attachment of enzymes that could lead to enzyme denaturation ${ }^{8,29}$, ${ }^{30}$. Further, at the working $\mathrm{pH}$ of 4.8 that is slightly above the isoelectric point of $\mathrm{CPO}(\mathrm{pI}=4)^{52}$ the $\mathrm{CPO}$ enzyme has a net negative charge and the $\mathrm{TiO}_{2}-\mathrm{NBs}$ (isoelectric point $\left.\mathrm{pI}=6.5\right)^{53}$ has a net positive charge, thus favoring the adsorption or non-specific binding of the CPO to the nanosupport and accounting for the reduced enzyme activity. Meanwhile, the higher activity observed for the CPO-PEG- $\mathrm{TiO}_{2}-\mathrm{NBs}$ was presumably due to the PEG spacer bringing the enzyme away from the nanosupport thus reducing non-specific enzyme interaction with the nanosupport and thus enzyme denaturation at the nanointerface ${ }^{31}$.

Kinetic constants were evaluated for the free CPO and compared to the kinetics of the CPO-based conjugates, i.e., CPO-TiO $2-\mathrm{NBs}$ and $\mathrm{CPO}-\mathrm{PEG}-\mathrm{TiO}_{2}-\mathrm{NBs}$, by using LineweaverBurk plots ${ }^{54}$. Namely, the $K_{m}$ (substrate concentration at which the initial reaction rate is half maximal) and $\mathrm{V}_{\max }$ (maximum initial rate of an enzyme catalyzed reaction) values of the CPO$\mathrm{TiO}_{2}-\mathrm{NBs}$ and CPO-PEG-TiO $2-\mathrm{NBs}$ conjugates are shown in Table 1 and compared to the free $\mathrm{CPO}$ in solution. The $\mathrm{K}_{\mathrm{m}}$ values were on the same order of magnitude for all analyzed samples; specifically found to be 480,270 and $490 \mu \mathrm{M}$, respectively, for the free, CPO-TiO $2-\mathrm{NBs}_{\text {and }}$ CPO-PEG- $\mathrm{TiO}_{2}-\mathrm{NBs}$ conjugates indicating that there was no significant conformational change of the enzyme active site upon immobilization. The apparent $\mathrm{K}_{\mathrm{m}}$ for the directly covalently conjugated enzyme was decreased by about $40 \%$ when compared to the free enzyme or the PEG covalently conjugated enzyme that showed no significant change. $\mathrm{V}_{\max }$ values were on the same order of magnitude (i.e., 27, 0.5 and $4.6 \mu \mathrm{M} \mathrm{mg}^{-1} \mathrm{~s}^{-1}$, respectively for the free, $\mathrm{CPO}-\mathrm{TiO}_{2}-\mathrm{NBs}$ and CPO-PEG-TiO $-\mathrm{NBs}$ conjugates); the $\mathrm{V}_{\max }$ for the covalently immobilized enzyme decreased about $98 \%$ and about $81 \%$ for the PEG immobilized samples when compared to the free enzyme in solution. The smaller $\mathrm{V}_{\max }$ obtained when the enzyme was immobilized directly via covalent binding was presumably due to the enzyme coming into direct contact with the 
nanosupport, decreasing the chance of a reaction to occur and consequently slowing the reaction rate. Our reported $\mathrm{K}_{\mathrm{m}}$ and $\mathrm{V}_{\max }$ results are on the same order of magnitude with previous studies reporting on the CPO immobilization at the carbon nanomaterial interface ${ }^{30}$, polymer coated magnetic nanoparticles interface ${ }^{55}$ or onto mesoporous silicate material ${ }^{56}$. Any deviations observed may result from the environmental differences in which the experiments were performed.

The efficiency factor $\eta$ was calculated from the maximum reaction rates of the immobilized CPO (both $\mathrm{CPO}-\mathrm{TiO}_{2}-\mathrm{NBs}$ and $\mathrm{CPO}-\mathrm{PEG}-\mathrm{TiO}_{2}-\mathrm{NBs}$ ) relative to the rate of the free enzyme in solution using

$$
\eta=\frac{v_{\text {immobilized }}}{v_{\text {free }}}, \text { where } v_{\text {immobilized }} \text { is the reaction rate of the immobilized enzyme (directly }
$$
through covalent binding or through PEG and covalent binding) and $v_{\text {free }}$ is the reaction rate of the free enzyme (Table 1). The efficiency factor for the $\mathrm{CPO}-\mathrm{TiO}_{2}-\mathrm{NBs}$ was 0.02 while the $\eta$ for the CPO-PEG-TiO 2 -NBs was 0.17 . The reduction in the efficiency factor observed for the immobilized enzyme further confirmed the non-specific interactions of the enzymes at the nanosupport interface and thus enzyme denaturation ${ }^{8,29,30}$.

To test whether the enzyme-nanosupport hybrid systems can generate in situ $\mathrm{H}_{2} \mathrm{O}_{2}$, we irradiated the systems under UV (i.e. UV-A $(\lambda=316-400 \mathrm{~nm})$ or UV-C $(\lambda=235-280 \mathrm{~nm})$, Figure 1c). Our data showed that there was negligible capability to allow the conversion of monochlorodimedon to dichlorodimedon in the presence of $\mathrm{Cl}^{-}$. Further, the enzyme-nanosupport hybrid systems showed negligible capability for $\mathrm{HOCl}$ generation even after 10, 30 or 60 min of continuous UV irradiation (both UV-A and UV-C). The negligible capabilities of the enzymenanosupport hybrid systems to ensure the conversion of monochlorodimedon to dichlorodimedon, or to generate $\mathrm{HOCl}$ upon UV irradiation, was presumably due to the limited $\mathrm{H}_{2} \mathrm{O}_{2}$ substrate concentration being available at the nanosupport interface. Specifically, with the substrate being exhausted in the CPO conversions (either of the monochlorodimedon to dichlorodimedon, or of the $\mathrm{Cl}^{-}$), the initially zero order reaction becomes a "leading" reaction, which does not allow the formation of high enough concentrations of enzyme-substrate complexes to become detectable. This was confirmed in our control experiments performed with free CPO (the same amount of free enzyme in solution as the amount of enzyme immobilized 
onto nanosupport and determined by the loading assay) that showed that for the reaction to be detectable, at least $1 \mu \mathrm{M}$ of $\mathrm{H}_{2} \mathrm{O}_{2}$ substrate needs to be present in solution (Figure $\mathrm{S} 2$, Appendix 2). Complementary, the suggested "leading reaction" is also supported by previous reports that have shown that the rate of $\mathrm{H}_{2} \mathrm{O}_{2}$ decomposition at the nanosupport interface is sharply increased at $\mathrm{pH}$ values above $4^{57}$ (our working $\mathrm{pH}$ is 4.8). Further, this rate of $\mathrm{H}_{2} \mathrm{O}_{2}$ decomposition could be accentuated as result of an initial adsorption step of $\mathrm{H}_{2} \mathrm{O}_{2}$ onto the nanosupport followed by a second process that consists of the cleavage of $\mathrm{H}_{2} \mathrm{O}_{2}$ at the oxide-based nanosupport interface ${ }^{58}$, 59 . Additionally, previous studies have shown the possibility of enzyme deactivation in enzyme$\mathrm{TiO}_{2}$ systems in the presence of UV light, which would add to loss of activity ${ }^{39,40}$.

While this strategy did not demonstrate the capability to detect $\mathrm{HOCl}$ in situ produced by CPO immobilized onto $\mathrm{TiO}_{2}-\mathrm{NBs}$ nanosupports, they demonstrated the feasibility of covalently immobilizing CPO at oxide-based interfaces to lead to active enzyme-based conjugates, with higher activities and kinetics being observed for the enzyme immobilized using a spacer. Such enzyme-nanosupport hybrid systems can further be exploited for the next generation of biosensors with electrochemical performances to be studied by cyclic voltammetry (CV) and amperometric methods ${ }^{60-62}$.

\section{STRATEGY 2: CO-IMMOBILIZED ENZYME-CARBON-BASED MATERIAL HYBRID SYSTEMS FOR IN SITU GENERATION OF HOCL}

In our second strategy, we hypothesized that carboxyl functionalized multi-walled carbon nanotubes (MWCNTs-COOH) can be used as an alternative to $\mathrm{TiO}_{2}-\mathrm{NBs}$ nanosupports to allow generation of $\mathrm{H}_{2} \mathrm{O}_{2}$ substrate necessary for the conversion of $\left(\mathrm{Cl}^{-}\right)$into $\mathrm{HOCl}$ in the presence of CPO. Our hypothesis was that $\mathrm{H}_{2} \mathrm{O}_{2}$ substrate can be produced through an enzymatic chain reaction at the MWCNT interface. Specifically, glucose oxidase $\left(\mathrm{GO}_{\mathrm{X}}\right)$ can be used for $\mathrm{H}_{2} \mathrm{O}_{2}$ generation ${ }^{63}$ that would further serve as substrate for the co-immobilized CPO to convert $\left(\mathrm{Cl}^{-}\right)$ into $\mathrm{HOCl}$ (Figure 2). MWCNTs-COOH were chosen as nanosupports because they have a significantly smaller diameter (MWCNTs diameter: 10-20 nm) and thus a higher surface curvature when compared to $\mathrm{TiO}_{2}-\mathrm{NBs}\left(\mathrm{TiO}_{2}-\mathrm{NBs}\right.$ diameter: 60-300 nm). The higher surface curvature will presumably reduce the non-specific interactions of the CPO with the nanosupport interface $29,31,64$, thus reducing enzyme denaturation and activity loss observed in Strategy 1. Further, the choice of the MWCNTs-COOH will avoid any $\mathrm{H}_{2} \mathrm{O}_{2}$ decomposition at the 
nanosupport interface thus making the hypothesis for the $\mathrm{HOCl}$ generation viable. Moreover, the high aspect to surface area ratio of the MWCNTs-COOH will allow high CPO loadings and ease of isolation of the enzyme-based hybrid systems through filtration ${ }^{29,31}$.

a)

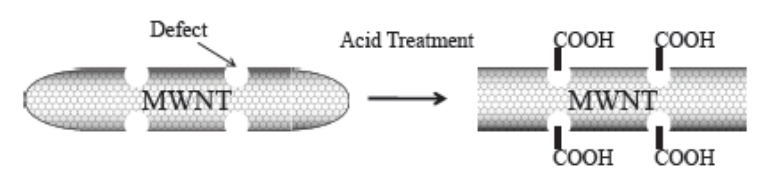

b)

)
$\mathrm{CPO}$

Covalent

Binding

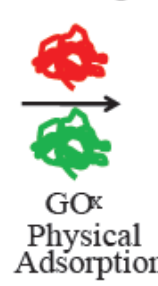

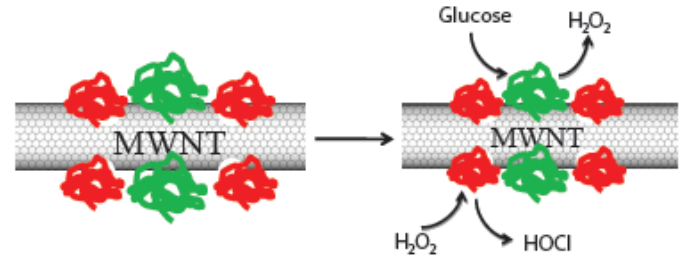

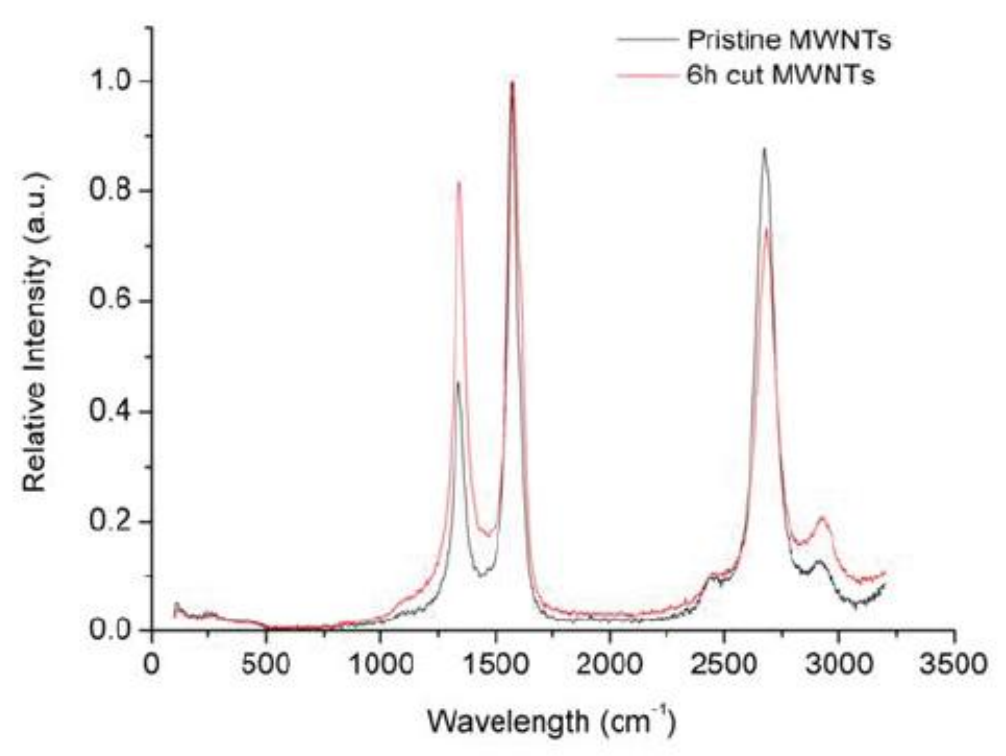

Figure 2: a) Acids treatment of MWCNTs leads to carboxyl functionalized MWCNTs (MWCNTs-COOH). Functionalization takes place at the defect sites in the MWCNTs structures; the resulting acid treated MWCNTs have hydrophilic residues (represented by the $\mathrm{COOH}$ groups) and hydrophobic walls. The MWCNTs-COOH are used as nanosupports for coimmobilization of $\mathrm{CPO}$ and $\mathrm{GO}_{\mathrm{X}}$. First, $\mathrm{CPO}$ is covalently attached to $\mathrm{COOH}$-functionalized MWCNTs. Subsequently, the CPO-based conjugates are used for the physical attachment of $\mathrm{GO}_{\mathrm{x}} ; \mathrm{GO}_{\mathrm{x}}$ will attach to the hydrophobic walls of the nanotubes to result in CPO-GO $\mathrm{x}-\mathrm{MWCNTs}$ conjugates. In the system containing the co-immobilized enzymes and through a chain reaction,

$\mathrm{GO}_{\mathrm{X}}$ provides the $\mathrm{H}_{2} \mathrm{O}_{2}$ substrate needed by $\mathrm{CPO}$ for in situ conversion of $\mathrm{Cl}^{-}$into $\mathrm{HOCl}$. b) Raman spectra of pristine (black curve) and carboxyl functionalized (red curve) MWCNTs. The carboxyl functionalized MWCNTs have shifted peaks towards higher relative intensities confirming the $\mathrm{COOH}$ functionalization. 
MWCNTs were first carboxyl functionalized through acid treatment as previously described $^{29}$ (Figure 2a). To evaluate whether there were any morphological and structural changes upon acid treatment, the resulting carboxyl functionalized MWCNTs (MWCNT-COOH) were characterized using Scanning Electron Microscopy (SEM), Atomic Force Microscopy (AFM) and Raman spectroscopy. No morphological changes were observed for the acid treated samples (Figure S3, Appendix 3) relative to pristine MWCNTs. However, the carboxyl functionalized MWCNTs were significantly shorter than pristine MWCNTs, with average lengths of $443 \pm 238$ when compared to the pristine original lengths of $5126 \pm 2283 \mathrm{~nm}$. The carboxyl functionalization was confirmed using Raman spectroscopy (Figure 2b). Specifically, the Raman spectrum showed the presence of 4 bands for both pristine and carboxyl functionalized MWCNTs samples, i.e. the so-called D band at around $1340 \mathrm{~cm}^{-1}$, G band at around $1580 \mathrm{~cm}^{-1}, \mathrm{G}^{\prime}$ band at around $2670 \mathrm{~cm}^{-1}$ and another band at around $2920 \mathrm{~cm}^{-1}$. The D band is associated with non-crystalline carbon species, such as defect sites on the MWCNTs wall surface $^{65}$. Compared to the pristine MWCNTs samples (black curve), the spectrum of the carboxyl functionalized samples (red curve) showed a wider D band shifted towards a higher frequency, indicating the addition of carboxyl groups on the nanotubes sidewall. The $G$ band observed around $1585 \mathrm{~cm}^{-1}$ showed the high degree of ordering of the MWCNTs ${ }^{66}$. Shifting the $\mathrm{G}$ band in carboxyl functionalized MWCNTs was associated with either the removal of metal catalyst particles, the increase of electron-accepting functional groups, or generation of amorphous carbon species ${ }^{37}$. Further, the $I_{D} / I_{G}$ ratio (ratio of the relative intensity of the D band relative to the $\mathrm{G}$ band indicates the level of functionalization) of MWCNTs increased from 0.457 to 0.817 , further confirming the carboxyl group functionalities (Table S1, Appendix 2).

To test the feasibility of the proposed approach, we first assessed whether MWCNTs would serve as viable nanosupports for CPO and GOx immobilization through either physical or covalent binding, and whether they ensure high activity and loading for each one of the enzymes being immobilized. The CPO-MWCNTs physically and covalently bound conjugates showed loadings of $0.10 \pm 0.02$ and $0.07 \pm 0.02 \mathrm{mg}$ enzyme $/ \mathrm{mg}$ nanosupport, respectively, which represented $20 \%$ and $14 \%$ of the amount of protein that was offered, respectively (Table S2). The specific activity of the physically bound conjugates was about $41 \%$ while the activity of the covalently bound conjugates was about $52 \%$ of the activity of the free enzyme in solution. The $\mathrm{GO}_{\mathrm{X}}-\mathrm{MWCNTs}$ physically and covalently bound conjugates showed loadings of $0.24 \pm 0.02$ and 
$0.25 \pm 0.02 \mathrm{mg}$ enzyme $/ \mathrm{mg}$ nanosupport, which represented $48 \%$ and $50 \%$ of the amount of protein that was offered, respectively (Table S3, Appendix 2). The specific activity of the physically bound conjugates was about $10 \%$, while the activity of the covalently bound conjugates was about $38 \%$ of the activity of the free enzyme in solution. The higher activities observed for both covalently bound $\mathrm{CPO}$ - and $\mathrm{GO}_{\mathrm{X}}$-MWCNTs conjugates was a result of the reduced non-specific binding of the enzyme onto the nanosupport and reduced enzyme-enzyme interactions ${ }^{29,31,64}$. Specifically, the smaller curvature of the cylindrical nanotube will result in an increase in the center-to-center distance between adjacent enzymes when compared to the enzyme immobilized onto $\mathrm{TiO}_{2}$-NBs nanosupport thus reducing unfavorable lateral interactions that could lead to enzyme deactivation ${ }^{67}$.

Kinetic constants were also evaluated and compared to the free enzyme in solution. The $\mathrm{K}_{\mathrm{m}}$ and $\mathrm{V}_{\max }$ values of the free and CPO-based conjugates are shown in Figure 3a and Table S2 (Appendix 2). The $\mathrm{K}_{\mathrm{m}}$ values were on the same order of magnitude for all analyzed samples indicating that, similarly to the $\mathrm{CPO}-\mathrm{TiO}_{2}$-based conjugates, the CPO-MWCNTs-based conjugates (either physically or covalently immobilized) did not show significant conformational change of the enzyme active site upon immobilization. Specifically, the values found were 480 , 340 and $530 \mu \mathrm{M}$, for the free, CPO physically adsorbed and CPO covalently bound, respectively. The apparent $\mathrm{K}_{\mathrm{m}}$ for the directly covalently conjugated enzyme was increased by about $10 \%$ when compared to the free enzyme. The $\mathrm{V}_{\max }$ values were also in the same order of magnitude and found to be 27,12 and $13 \mu \mathrm{M} \mathrm{mg}^{-1} \mathrm{~s}^{-1}$, respectively for the free CPO, CPO physically adsorbed and CPO covalently immobilized onto MWCNTs. The $\mathrm{V}_{\max }$ values of both the covalently and physically immobilized enzyme decreased by only about $50 \%$ when compared to the free enzyme in solution. This represents an increase of about $61 \%$ when compared to the $\mathrm{V}_{\max }$ of the $\mathrm{CPO}-\mathrm{TiO}_{2}$-based conjugates further supporting that MWCNTs nanosupports provide a viable alternative in terms of reducing the enzyme non-specific interaction to the interface that could have slowed down the reaction rate. 
a)

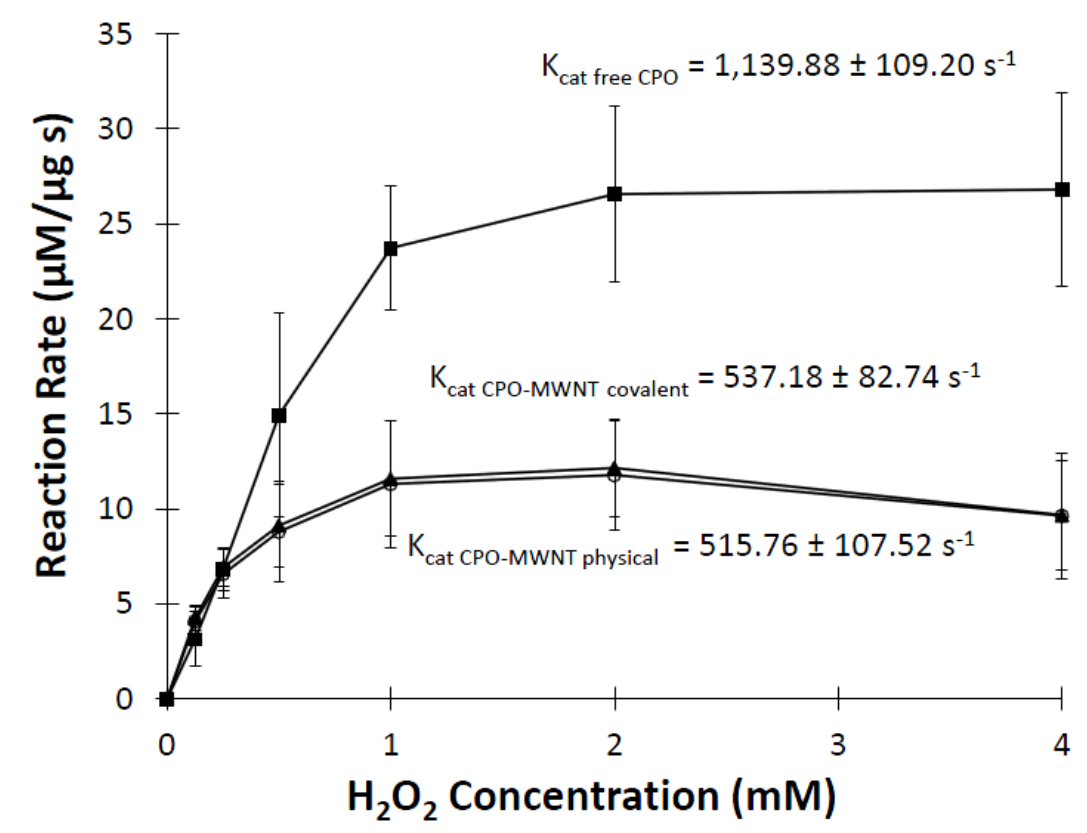

b)

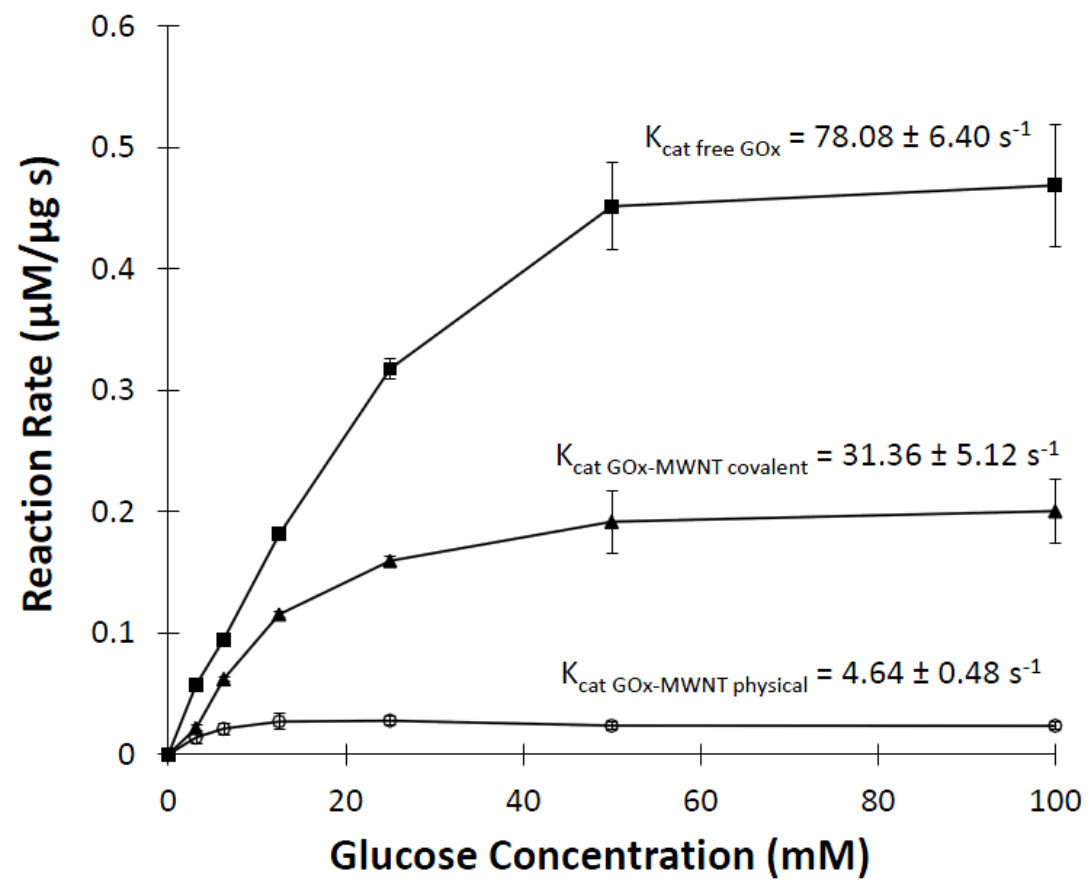

Figure 3: a) Michaelis-Menten kinetics of enzyme-based MWCNTs conjugates. a) CPObased conjugates (physically immobilized-open circles; covalently immobilized- filled triangles) kinetics relative to free $\mathrm{CPO}$ in solution (filled squares). b) $\mathrm{GO}_{\mathrm{x}}$-based conjugates (physically immobilized-open circles; covalently immobilized- filled triangles) kinetics relative to free $\mathrm{GO}_{\mathrm{x}}$ in solution (filled squares). 
The $\mathrm{K}_{\mathrm{m}}$ and $\mathrm{V}_{\max }$ values of the free and $\mathrm{GO}_{\mathrm{X}}$-based conjugates (both physically and covalently immobilized) are shown in Figure $3 b$ and Table S3 (Appendix 2). Specifically, the $\mathrm{K}_{\mathrm{m}}$ values were $2,600,1,800$, and 3,200 $\mu \mathrm{M}$ for free $\mathrm{GO}_{\mathrm{X}}, \mathrm{GO}_{\mathrm{X}}$ physically and $\mathrm{GO}_{\mathrm{X}}$ covalently immobilized, respectively. The apparent $\mathrm{K}_{\mathrm{m}}$ for the covalently bound enzyme decreased about 23 $\%$ whereas the value for the physically bound enzyme increased about $30 \%$. The $\mathrm{V}_{\max }$ values were found to be $0.49,0.03$ and $0.20 \mu \mathrm{M} \mathrm{mg}^{-1} \mathrm{~s}^{-1}$, respectively for free $\mathrm{GO}_{\mathrm{X}}, \mathrm{GO}_{\mathrm{X}}$ physically and $\mathrm{GO}_{\mathrm{X}}$ covalently bound. The $94 \%$ and $60 \%$ decreases in $\mathrm{V}_{\max }$ for covalently bound and physically adsorbed $\mathrm{GO}_{\mathrm{X}}$, were presumably due to the non-specific attachment of the $\mathrm{GO}_{\mathrm{X}}$ or enzyme-enzyme interaction at the nanointerface that could have slowed the reaction rate.

The efficiency factor $\eta$ was also calculated from the maximum reaction rates of the immobilized CPO or $\mathrm{GO}_{\mathrm{x}}$ (both through physical and covalent binding) and relative to the rate of the free enzyme in solution (see Strategy 1 and Tables S2 and S3, respectively, Appendix 2). The efficiency factor for the CPO-physically adsorbed conjugates was 0.45 while the $\eta$ for the CPO immobilized via covalent binding was 0.47. The efficiency factor for the $\mathrm{GO}_{\mathrm{x}}$-physically adsorbed conjugates was 0.06 while the $\eta$ for the $\mathrm{GO}_{\mathrm{x}}$ immobilized via covalent binding was 0.40. The catalytic efficiency was increased when compared to the covalently bound $\mathrm{CPO}-\mathrm{TiO}_{2}$ based conjugates further supporting the conjugates obtained at the MWCNTs interface were highly active and viable platform for the enzyme co-immobilization strategy.

Once it was confirmed that individual $\mathrm{CPO}$ and GOx resulted in highly active conjugates at the MWCNTs interface, MWCNTs-COOH were used for the co-immobilization of CPO and GOx to lead to the next generation of in situ microbial decontamination hybrid systems (Figure 2a). For such a system to be viable, both enzymes must be successfully immobilized onto the surface of the same nanosupport, remain active upon immobilization and allow the promotion of a chain reaction through their co-immobilization conditions (i.e. the product of one enzyme to serve as the substrate of the co-immobilized enzyme in order to generate the $\mathrm{HOCl}$ decontaminant). We rationalized that using a $-\mathrm{COOH}$ functionalized nanosupport is a viable platform to ensure a successful co-immobilization strategy since the - $\mathrm{COOH}$ groups could serve as active groups for covalent immobilization of one enzyme, while the hydrophobic walls of the nanotube will provide additional space for physical adsorption of a second enzyme ${ }^{68}$. Briefly, either $\mathrm{CPO}$ or $\mathrm{GO}_{\mathrm{X}}$ was covalently immobilized onto MWCNTs-COOH using EDC/NHS 
chemistry ${ }^{29}$ followed by the physical adsorption of the second enzyme. Both combinations were investigated (i.e. $\mathrm{CPO}$ covalent and $\mathrm{GO}_{\mathrm{X}}$ physical; and $\mathrm{GO}_{\mathrm{X}}$ covalent and $\mathrm{CPO}$ physical). The resulting loadings of the two co-immobilized enzymes onto the same nanosupport are shown in Table 2. CPO-GOX-based MWCNTs-COOH hybrid systems were further used to test whether they allow the generation of $\mathrm{HOCl}$ through a chain reaction at the nanotube interface (Figure 2a; i.e. to test whether $\mathrm{GO}_{X}$ will generate enough $\mathrm{H}_{2} \mathrm{O}_{2}$ for the conversion of $\left(\mathrm{Cl}^{-}\right)$in the presence of $\mathrm{CPO}$ into $\mathrm{HOCl}$ ). Our data has shown that the hypothesized co-immobilization strategy was highly efficient in that both enzymes maintained their individual activities and kinetics characteristics and were able to generate $\mathrm{HOCl}$ as the final product from their chain reaction at the nanosupport interface. The rate of in situ $\mathrm{HOCl}$ generation correlated with the loadings, activities and kinetics of the two enzymes. Our data showed that the chain reaction at the

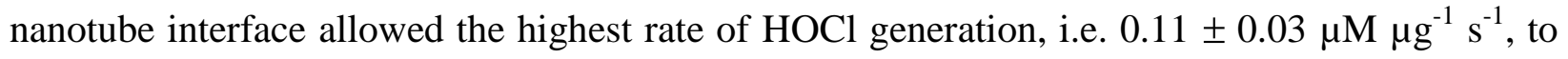
be achieved by the conjugates that contained covalently immobilized CPO and physically adsorbed $\mathrm{GO}_{\mathrm{X}}$. The conjugates that contained covalently immobilized $\mathrm{GO}_{\mathrm{X}}$ and physically

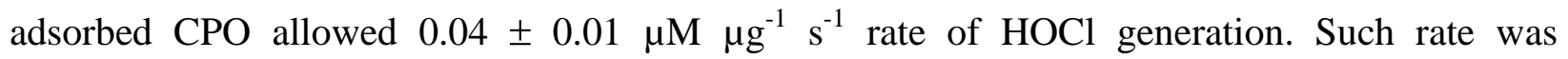
previously shown to adequately induce microbial and bacterial decontamination ${ }^{69}$. Further, our strategy demonstrated that these conjugates retained about $50 \%$ of their activities even after 4 weeks storage at $4{ }^{\circ} \mathrm{C}$ and about $40 \%$ at $23{ }^{\circ} \mathrm{C}$ (Table S4, Appendix 2)).

Table 2: CPO-MWCNT-GOX conjugates generate $\mathrm{HOCl}$ in situ. The rate of $\mathrm{HOCl}$ generation is dependent on the enzyme immobilization conditions (i.e., through physical or covalent binding).

\begin{tabular}{|c|c|c|}
\hline Parameter & $\begin{array}{c}\text { CPO-MWCNT- } \\
\text { GO }_{\mathrm{X}} \\
\text { (CPO covalent } \\
\left.\mathrm{GO}_{\mathrm{X}} \text { physical }\right)\end{array}$ & 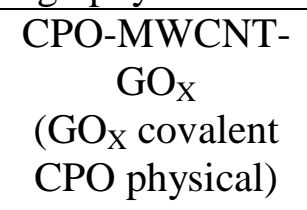 \\
\hline $\begin{array}{c}\text { Loading } \\
\text { (mg protein/mg } \\
\text { nanosupport) }\end{array}$ & $\begin{array}{l}\text { CPO: } 0.07 \pm 0.02 \\
\text { GO }_{X}: 0.19 \pm 0.04\end{array}$ & $\begin{array}{l}\text { CPO: } 0.09 \pm 0.02 \\
\text { GO }_{X}: 0.17 \pm 0.02\end{array}$ \\
\hline $\begin{array}{l}\text { Loading function of } \\
\text { enzyme offered }(\%)\end{array}$ & $\begin{array}{l}\text { CPO: } 14 \\
\mathrm{GO}_{\mathrm{X}}: 38\end{array}$ & $\begin{array}{l}\text { CPO: } 18 \\
\mathrm{GO}_{\mathrm{X}}: 34\end{array}$ \\
\hline $\begin{array}{l}\text { Rate of } \mathrm{HOCl} \\
\left(\mu \mathrm{M} \mu \mathrm{g}^{-1} \mathrm{~s}^{-1}\right)\end{array}$ & $0.11 \pm 0.03$ & $0.04 \pm 0.01$ \\
\hline
\end{tabular}


Our $2^{\text {nd }}$ Strategy showed the feasibility of in situ $\mathrm{HOCl}$ generation at a nanosupport interface through an enzymatic chain reaction. This strategy can overcome the disadvantages of immobilizing enzymes onto different nanosupports and mixing them upon use, such as the reductions in reactivity and stability that are usually correlated with differences in optimal $\mathrm{pH}^{\prime} \mathrm{s}^{70}$. Further, such enzyme-based conjugates can be incorporated into coatings to create selfsustainable surfaces with enhanced microbial decontamination capabilities ${ }^{8,29-31}$. For instance, one could envision the encapsulation of dextrin or dextrin-derivates into paint or polymer-based coatings $^{29,31,71,72}$ together with these prepared enzyme-carbon-based material hybrid systems; further exposure of such coatings to ambient $\left(\mathrm{Cl}^{-}\right)^{73}$ will lead to in situ generation of $\mathrm{HOCl}$ and thus provide a self-cleaning and self-sustainable microbial decontamination coating.

\section{CONCLUSIONS}

Two different strategies were explored for in situ generation of $\mathrm{HOCl}$ through an enzymatic reaction. In our strategies CPO working enzyme was immobilized either at a photocatalyst$\left(\mathrm{TiO}_{2}-\mathrm{NB}_{\mathrm{s}}\right)$ or at a carbon-based nanosupport (MWCNTs-COOH) interface. CPO immobilized onto MWCNTs showed $52 \%$ increase in the specific retained activity when compared to the CPO immobilized onto $\mathrm{TiO}_{2}-\mathrm{NB}_{\mathrm{s}}$. CPO-MWCNT-based hybrid systems were capable of generating $\mathrm{HOCl}$ at a high rate known to be feasible for microbial decontamination. This research can be viewed as an important first step toward creating self-sustainable microbial decontamination coatings to be used against various pathogens such as bacteria and spores. Further, these co-immobilized-enzyme-MWCNTs-based conjugates are interesting as active biohybrid nanomaterials; for instance, one can arrange given enzymes onto the same nanosupport according to a specific function thus making sequential enzymatic reactions at nanobiointerfaces become feasible for biosensor applications. 


\section{REFERENCES}

1. Karayylanoglu, T.; Kenar, L.; Karayylanoglu, T.; Gulec, M., How would military hospitals cope with a nuclear, biological, or chemical disaster? Mil Med 2004, 169, (10), 757-760.

2. Hardy, K. J.; Gossain, S.; Henderson, N.; Drugan, C.; Oppenheim, B. A.; Gao, F.; Hawkey, P. M., Rapid recontamination with MRSA of the environment of an intensive care unit after decontamination with hydrogen peroxide vapour. J Hosp Infect 2007, 66, (4), 360-368.

3. Sexton, J. D.; Tanner, B. D.; Maxwell, S. L.; Gerba, C. P., Reduction in the microbial load on high-touch surfaces in hospital rooms by treatment with a portable saturated steam vapor disinfection system. Am J Infect Control 2011, 39, (8), 655-662.

4. Wren, M. W. D.; Rollins, M. S. M.; Jeanes, A.; Hall, T. J.; Coen, P. G.; Gant, V. A., Removing bacteria from hospital surfaces: a laboratory comparison of ultramicrofibre and standard cloths. J Hosp Infect 2008, 70, (3), 265-271.

5. Weber, D. J.; Rutala, W. A.; Miller, M. B.; Huslage, K.; Sickbert-Bennett, E., Role of hospital surfaces in the transmission of emerging health care-associated pathogens: Norovirus, Clostridium difficile, and Acinetobacter species. Am J Infect Control 2010, 38, (5), S25-S33.

6. Nerandzic, M. M.; Cadnum, J. L.; Eckart, K. E.; Donskey, C. J., Evaluation of a hand-held far-ultraviolet radiation device for decontamination of Clostridium difficile and other healthcareassociated pathogens. Bmc Infect Dis 2012, 12.

7. Russell, A. J.; Berberich, J. A.; Drevon, G. E.; Koepsel, R. R., Biomaterials for mediation of chemical and biological warfare agents. Annual review of biomedical engineering 2003, 5, 1-27.

8. Borkar, I. V.; Dinu, C. Z.; Zhu, G. Y.; Kane, R. S.; Dordick, J. S., Bionanoconjugate-Based Composites for Decontamination of Nerve Agents. Biotechnol Progr 2010, 26, (6), 1622-1628.

9. Mansee, A. H.; Chen, W.; Mulchandani, A., Detoxification of the organophosphate nerve agent coumaphos using organophosphorus hydrolase immobilized on cellulose materials. $J$ Ind Microbiol Biot 2005, 32, (11-12), 554-560.

10. Seto, Y., Research and Development of On-site Decontamination System for Biological and Chemical Warfare Agents. J Health Sci 2011, 57, (4), 311-333.

11. Tiller, J. C.; Lee, S. B.; Lewis, K.; Klibanov, A. M., Polymer surfaces derivatized with poly(vinyl-N-hexylpyridinium) kill airborne and waterborne bacteria. Biotechnol Bioeng 2002, $79,(4), 465-471$. 
12. Taylor, G. R.; Butler, M., A Comparison of the Virucidal Properties of Chlorine, Chlorine Dioxide, Bromine Chloride and Iodine. J Hyg-Cambridge 1982, 89, (2), 321-\&.

13. Cousins, C. M.; Allan, C. D., Sporicidal Properties of Some Halogens. J Appl Bacteriol 1967, 30, (1), 168-\&.

14. NIOSH, Guidelines for protecting the safety and health of health care workers. In 1988; pp 88-119.

15. Amitai, G.; Andersen, J.; Wargo, S.; Asche, G.; Chir, J.; Koepsel, R.; Russell, A. J., Polyurethane-based leukocyte-inspired biocidal materials. Biomaterials 2009, 30, (33), 65226529.

16. Amitai, G.; Murata, H.; Andersen, J. D.; Koepsel, R. R.; Russell, A. J., Decontamination of chemical and biological warfare agents with a single multi-functional material. Biomaterials 2010, 31, (15), 4417-4425.

17. Herrmann, H. W.; Selwyn, G. S.; Henins, I.; Park, J.; Jeffery, M.; Williams, J. M., Chemical warfare agent decontamination studies in the plasma decon chamber. Ieee T Plasma Sci 2002, 30, (4), 1460-1470.

18. Pan, J. H.; Lei, Z. B.; Lee, W. I.; Xiong, Z. G.; Wang, Q.; Zhao, X. S., Mesoporous TiO2 photocatalytic films on stainless steel for water decontamination. Catal Sci Technol 2012, 2, (1), 147-155.

19. Wu, T. S.; Wang, K. X.; Li, G. D.; Sun, S. Y.; Sun, J.; Chen, J. S., MontmorilloniteSupported Ag/TiO2 Nanoparticles: An Efficient Visible-Light Bacteria Photodegradation Material. Acs Appl Mater Inter 2010, 2, (2), 544-550.

20. Bestetti, M.; Sacco, D.; Brunella, M. F.; Franz, S.; Amadelli, R.; Samiolo, L., Photocatalytic degradation activity of titanium dioxide sol-gel coatings on stainless steel wire meshes. Mater Chem Phys 2010, 124, (2-3), 1225-1231.

21. Sapkota, A.; Anceno, A. J.; Baruah, S.; Shipin, O. V.; Dutta, J., Zinc oxide nanorod mediated visible light photoinactivation of model microbes in water. Nanotechnology 2011, 22, (21).

22. Mahato, T. H.; Prasad, G. K.; Singh, B.; Acharya, J.; Srivastava, A. R.; Vijayaraghavan, R., Nanocrystalline zinc oxide for the decontamination of sarin. J Hazard Mater 2009, 165, (1-3), 928-932. 
23. Xu, H. Y.; Qu, F.; Xu, H.; Lai, W. H.; Wang, Y. A.; Aguilar, Z. P.; Wei, H., Role of reactive oxygen species in the antibacterial mechanism of silver nanoparticles on Escherichia coli O157:H7. Biometals 2012, 25, (1), 45-53.

24. Fullenkamp, D. E.; Rivera, J. G.; Gong, Y. K.; Lau, K. H. A.; He, L. H.; Varshney, R.; Messersmith, P. B., Mussel-inspired silver-releasing antibacterial hydrogels. Biomaterials 2012, 33, (15), 3783-3791.

25. Dankovich, T. A.; Gray, D. G., Bactericidal Paper Impregnated with Silver Nanoparticles for Point-of-Use Water Treatment. Environ Sci Technol 2011, 45, (5), 1992-1998.

26. Lambert, R. J. W.; Johnston, M. D.; Simons, E. A., A kinetic study of the effect of hydrogen peroxide and peracetic acid against Staphylococcus aureus and Pseudomonas aeruginosa using the Bioscreen disinfection method. J Appl Microbiol 1999, 87, (5), 782-786.

27. Cady, N. C.; Behnke, J. L.; Strickland, A. D., Copper-Based Nanostructured Coatings on Natural Cellulose: Nanocomposites Exhibiting Rapid and Efficient Inhibition of a Multi-Drug Resistant Wound Pathogen, A. baumannii, and Mammalian Cell Biocompatibility In Vitro. Adv Funct Mater 2011, 21, (13), 2506-2514.

28. Yoon, K. Y.; Byeon, J. H.; Park, C. W.; Hwang, J., Antimicrobial effect of silver particles on bacterial contamination of activated carbon fibers. Environ Sci Technol 2008, 42, (4), 12511255 .

29. Dinu, C. Z.; Zhu, G.; Bale, S. S.; Anand, G.; Reeder, P. J.; Sanford, K.; Whited, G.; Kane, R. S.; Dordick, J. S., Enzyme-Based Nanoscale Composites for Use as Active Decontamination Surfaces. Adv Funct Mater 2010, 20, (3), 392-398.

30. Grover, N.; Borkar, I. V.; Dinu, C. Z.; Kane, R. S.; Dordick, J. S., Laccase- and chloroperoxidase-nanotube paint composites with bactericidal and sporicidal activity. Enzyme Microb Tech 2012, 50, (6-7), 271-279.

31. Dinu, C. Z.; Borkar, I. V.; Bale, S. S.; Campbell, A. S.; Kane, R. S.; Dordick, J. S., Perhydrolase-nanotube-paint sporicidal composites stabilized by intramolecular crosslinking. $J$ Mol Catal B-Enzym 2012, 75, 20-26.

32. Asuri, P.; Karajanagi, S. S.; Yang, H. C.; Yim, T. J.; Kane, R. S.; Dordick, J. S., Increasing protein stability through control of the nanoscale environment. Langmuir 2006, 22, (13), 58335836. 
33. Asuri, P.; Karajanagi, S. S.; Vertegel, A. A.; Dordick, J. S.; Kane, R. S., Enhanced stability of enzymes adsorbed onto nanoparticles. J Nanosci Nanotechno 2007, 7, (4-5), 1675-1678.

34. Vaitheeswaran, S.; Garcia, A. E., Protein stability at a carbon nanotube interface. J Chem Phys 2011, 134, (12).

35. Aburto, J.; Ayala, M.; Bustos-Jaimes, I.; Montiel, C.; Terres, E.; Dominguez, J. M.; Torres, E., Stability and catalytic properties of chloroperoxidase immobilized on SBA-16 mesoporous materials. Micropor Mesopor Mat 2005, 83, (1-3), 193-200.

36. Renirie, R.; Dewilde, A.; Pierlot, C.; Wever, R.; Hober, D.; Aubry, J. M., Bactericidal and virucidal activity of the alkalophilic P395D/L241V/T343A mutant of vanadium chloroperoxidase. J Appl Microbiol 2008, 105, (1), 264-270.

37. Dong, C., Campbell, A., Eldawud, R., Perhinschi, G., Rojansakul, Y., Dinu, C., Effects of Acid Treatment on Structure, Properties and Biocompatability of Carbon Nanotubes, in press. Appl Surf Sci 2012.

38. Dong, C.; Kashon, M. L.; Lowry, D.; Dordick, J. S.; Reynolds, S. H.; Rojanasakul, Y.; Sargent, L. M.; Dinu, C. Z., Exposure to Carbon Nanotubes Leads to Changes in the Cellular Biomechanics. Advanced healthcare materials 2013.

39. Lele, B. S.; Russell, A. J., Enhancing enzyme stability against TiO2-UV induced inactivation. Biomacromolecules 2005, 6, (1), 475-482.

40. Lele, B. S.; Russell, A. J., Rational protein modification leading to resistance of enzymes to TiO2-UV irradiation-induced inactivation. Biomacromolecules 2004, 5, (5), 1947-1955.

41. Maikala, R. V., Modified Beer's Law - historical perspectives and relevance in near-infrared monitoring of optical properties of human tissue. Int J Ind Ergonom 2010, 40, (2), 125-134.

42. Takahara, Y. K.; Hanada, Y.; Ohno, T.; Ushiroda, S.; Ikeda, S.; Matsumura, M., Photooxidation of organic compounds in a solution containing hydrogen peroxide and $\mathrm{TiO} 2$ particles under visible light. J Appl Electrochem 2005, 35, (7-8), 793-797.

43. Khodadoust, S.; Sheini, A.; Armand, N., Photocatalytic degradation of monoethanolamine in wastewater using nanosized TiO2 loaded on clinoptilolite. Spectrochim Acta A 2012, 92, 91-95.

44. Wu, T. X.; Liu, G. M.; Zhao, J. C.; Hidaka, H.; Serpone, N., Evidence for H2O2 generation during the TiO2-assisted photodegradation of dyes in aqueous dispersions under visible light illumination. J Phys Chem B 1999, 103, (23), 4862-4867. 
45. Malato, S.; Fernandez-Ibanez, P.; Maldonado, M. I.; Blanco, J.; Gernjak, W., Decontamination and disinfection of water by solar photocatalysis: Recent overview and trends. Catal Today 2009, 147, (1), 1-59.

46. Besov, A. S.; Krivova, N. A.; Vorontsov, A. V.; Zaeva, O. B.; Kozlov, D. V.; Vorozhtsov, A. B.; Parmon, V. N.; Sakovich, G. V.; Komarov, V. F.; Smirniotis, P. G.; Eisenreich, N., Air detoxification with nanosize TiO2 aerosol tested on mice. J Hazard Mater 2010, 173, (1-3), 4046.

47. Wang, J.; Li, M.; Zhi, M. J.; Manivannan, A.; Wu, N. Q., Hydrothermal Synthesis and Photocatalytic Activity of Titanium Dioxide Nanotubes, Nanowires and Nanospheres. Prog Probab 2009, 61, 71-76.

48. Guo, H., Wang, X., Qian, Q., Wang, F., Xia, X., A Green Approach to the Synthesis of Graphene Nanosheets. Acs Nano 2009, 3, (9), 2653-26559.

49. Wang, J.; Tafen, D. N.; Lewis, J. P.; Hong, Z. L.; Manivannan, A.; Zhi, M. J.; Li, M.; Wu, N. Q., Origin of Photocatalytic Activity of Nitrogen-Doped TiO2 Nanobelts. J Am Chem Soc 2009, 131, (34), 12290-12297.

50. Tafen, D. N.; Wang, J.; Wu, N. Q.; Lewis, J. P., Visible light photocatalytic activity in nitrogen-doped TiO2 nanobelts. Appl Phys Lett 2009, 94, (9).

51. Manta, C.; Ferraz, N.; Betancor, L.; Antunes, G.; Batista-Viera, F.; Carlsson, J.; Caldwell, K., Polyethylene glycol as a spacer for solid-phase enzyme immobilization. Enzyme Microb Tech 2003, 33, (7), 890-898.

52. Aoun, S.; Chebli, C.; Baloulene, M., Noncovalent immobilization of chloroperoxidase onto talc: Catalytic properties of a new biocatalyst. Enzyme Microb Tech 1998, 23, (6), 380-385.

53. Sharabi, D.; Paz, Y., Preferential photodegradation of contaminants by molecular imprinting on titanium dioxide. Appl Catal B-Environ 2010, 95, (1-2), 169-178.

54. Al-Haque, N.; Santacoloma, P. A.; Neto, W.; Tufvesson, P.; Gani, R.; Woodley, J. M., A robust methodology for kinetic model parameter estimation for biocatalytic reactions. Biotechnol Progr 2012, 28, (5), 1186-1196.

55. Wang, W.; Xu, Y.; Wang, D. I. C.; Li, Z., Recyclable Nanobiocatalyst for Enantioselective Sulfoxidation: Facile Fabrication and High Performance of Chloroperoxidase-Coated Magnetic Nanoparticles with Iron Oxide Core and Polymer Shell. J Am Chem Soc 2009, 131, (36), 12892+ . 
56. Han, Y. J.; Watson, J. T.; Stucky, G. D.; Butler, A., Catalytic activity of mesoporous silicateimmobilized chloroperoxidase. J Mol Catal B-Enzym 2002, 17, (1), 1-8.

57. Akhtar, K.; Khalid, N.; Ali, M., Effect of $\mathrm{pH}$ and Temperature on the Catalytic Properties of Manganese dioxide. J Chem Soc Pakistan 2012, 34, (2), 263-268.

58. Lousada, C. M.; Johansson, A. J.; Brinck, T.; Jonsson, M., Mechanism of H2O2 Decomposition on Transition Metal Oxide Surfaces. J Phys Chem C 2012, 116, (17), 9533-9543. 59. Soleymani, M.; Moheb, A.; Babakhani, D., Hydrogen Peroxide Decomposition over Nanosized La1-XCaXMnO3 (0 < = X < = 0.6) Perovskite Oxides. Chem Eng Technol 2011, 34, (1), 49-55.

60. Ganesh, V.; Muthurasu, A., Strategies for an enzyme immobilization on electrodes: Structural and electrochemical characterizations. J Phys Conf Ser 2012, 358.

61. Maniruzzaman, M.; Jang, S. D.; Kim, J., Titanium dioxide-cellulose hybrid nanocomposite and its glucose biosensor application. Mater Sci Eng B-Adv 2012, 177, (11), 844-848.

62. Zhang, M. H.; Yuan, R.; Chai, Y. Q.; Li, W. J.; Zhong, H.; Wang, C., Glucose biosensor based on titanium dioxide-multiwall carbon nanotubes-chitosan composite and functionalized gold nanoparticles. Bioproc Biosyst Eng 2011, 34, (9), 1143-1150.

63. Tao, Z. M.; Raffel, R. A.; Souid, A. K.; Goodisman, J., Kinetic Studies on EnzymeCatalyzed Reactions: Oxidation of Glucose, Decomposition of Hydrogen Peroxide and Their Combination. Biophys J 2009, 96, (7), 2977-2988.

64. Shang, W.; Nuffer, J. H.; Muniz-Papandrea, V. A.; Colon, W.; Siegel, R. W.; Dordick, J. S., Cytochrome c on Silica Nanoparticles: Influence of Nanoparticle Size on Protein Structure, Stability, and Activity. Small 2009, 5, (4), 470-476.

65. Kalbac, M.; Hsieh, Y. P.; Farhat, H.; Kavan, L.; Hofmann, M.; Kong, J.; Dresselhaus, M. S., Defects in Individual Semiconducting Single Wall Carbon Nanotubes: Raman Spectroscopic and in Situ Raman Spectroelectrochemical Study. Nano Lett 2010, 10, (11), 4619-4626.

66. Dresselhaus, M. S.; Jorio, A.; Hofmann, M.; Dresselhaus, G.; Saito, R., Perspectives on Carbon Nanotubes and Graphene Raman Spectroscopy. Nano Lett 2010, 10, (3), 751-758.

67. Asuri, P.; Bale, S. S.; Karajanagi, S. S.; Kane, R. S., The protein-nanomaterial interface. current opinion in biotechnology 2006, 17, (6), 562-568.

68. Ye, P.; Wan, R. B.; Wang, X. P., Quantitative enzyme immobilization: Control of the carboxyl group density on support surface. J Mol Catal B-Enzym 2009, 61, (3-4), 296-302. 
69. Wang, L., Bassiri, M., Najafi, R., Najafi, K., Yang, J., Khosrovi, B., Hwong, W., Barati, E., Belisle, B., Celeri, C., Robson, M.C., Hypochlorous Acid as a Potential Wound Care Agent. Journal of Burns and Wounds 2007, 6, (e5), 65-79.

70. Altikatoglu, M.; Basaran, Y.; Arioz, C.; Ogan, A.; Kuzu, H., Glucose Oxidase-dextran Conjugates with Enhanced Stabilities Against Temperature and pH. Appl Biochem Biotech 2010, $160,(8), 2187-2197$.

71. Predoi, D., A study on iron oxide nanoparticles coated with dextrin obtained by coprecipitation. Dig J Nanomater Bios 2007, 2, (1), 169-173.

72. Woodhall, E. W., Swidler, R. Dextrin-based protective coating compositions and methods of use thereof 2000.

73. Prosek, T.; Thierry, D.; Olsson, M.; Bexell, U., Effect of chloride-to-chromate ratio on the protective action of zinc surface films under atmospheric weathering conditions. Corrosion 2007, 63, (3), 258-267. 


\section{APPENDIX 2}

a)

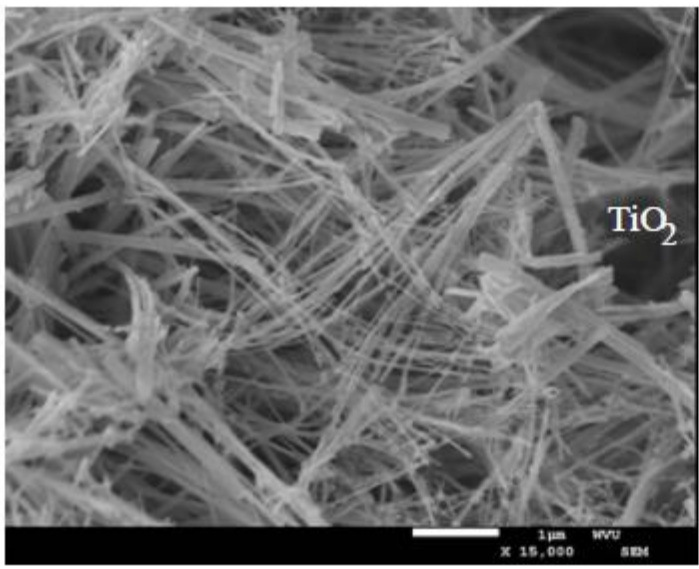

b)

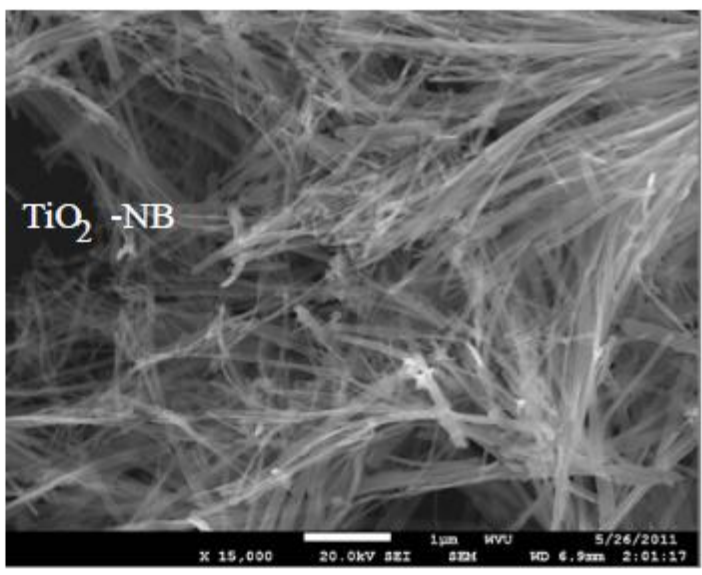

Figure S1: SEM images of a) pristine titanium dioxide and b) $\mathrm{TiO}_{2}-\mathrm{NBs}$. No changes in the morphology of the samples have been identified after - $\mathrm{COOH}$ functionalization.

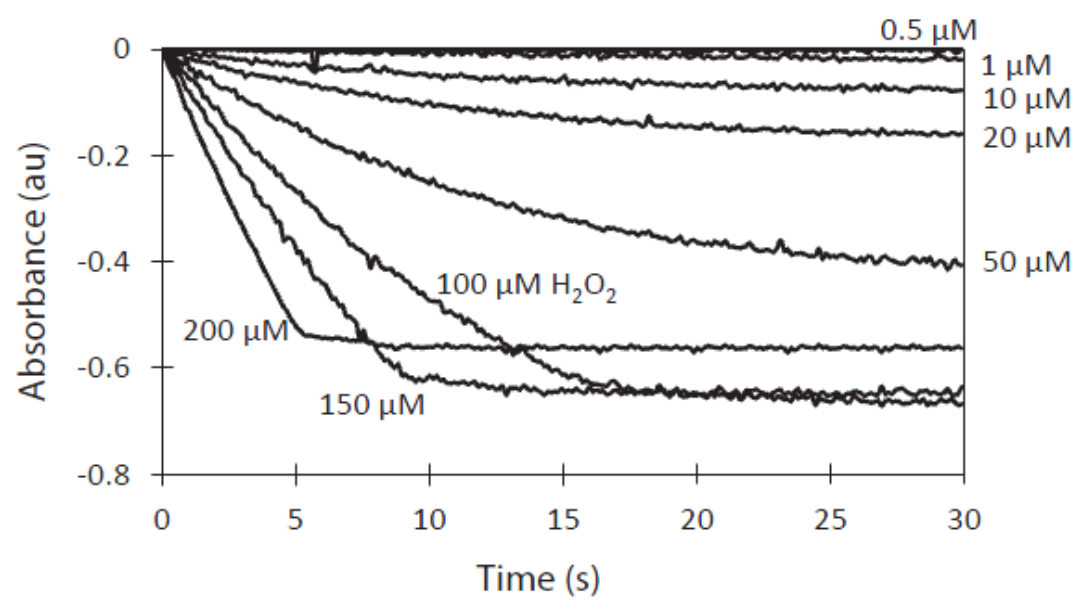

Monochlorodimedon $+\mathrm{H}_{2} \mathrm{O}_{2}+\mathrm{Cl}^{-}+\mathrm{H}^{+} \underset{278 \mathrm{~nm}}{\stackrel{\mathrm{CPO}}{\longrightarrow}}$ Dichlorodimedon $+\mathrm{H}_{2} \mathrm{O}$

Figure S2: Colorimetric reaction showing the conversion of MCD at constant $\mathrm{CPO}$ concentration and various $\mathrm{H}_{2} \mathrm{O}_{2}$ concentrations. The minimum $\mathrm{H}_{2} \mathrm{O}_{2}$ for which conversion was observed was $1 \mu \mathrm{M}$. 
a)

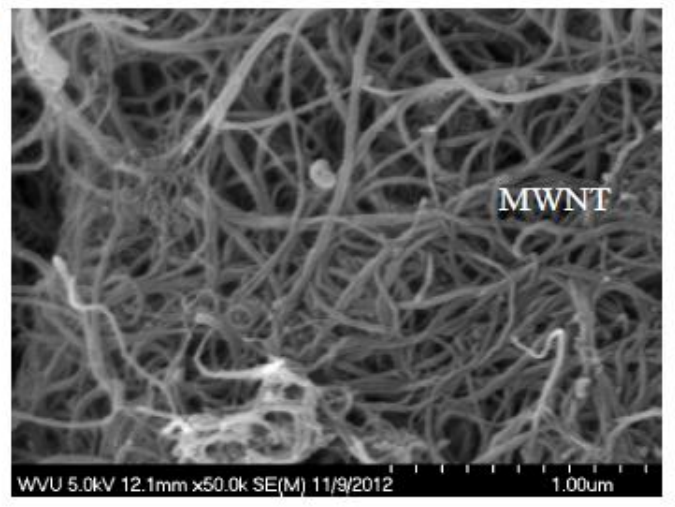

b)

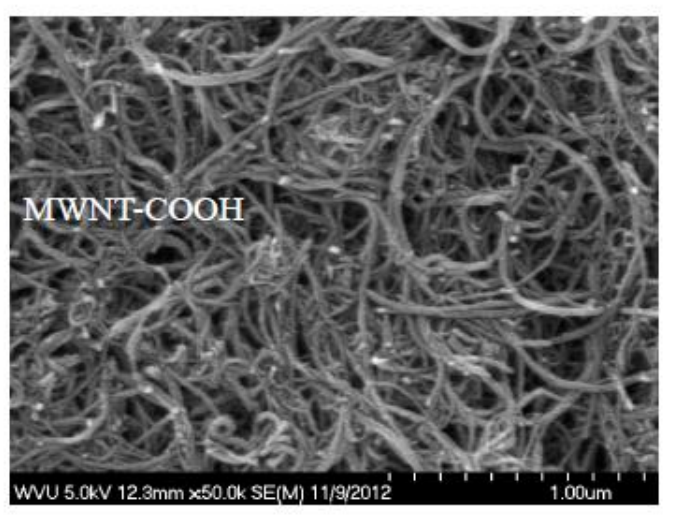

Figure S3: SEM images of a) Pristine MWCNTs and b) Carboxyl functionalized MWCNTs. No morphological differences were recorded between the pristine and the acids treated samples.

Table S1: MWCNTs Raman analysis data.

\begin{tabular}{|c|c|c|c|}
\hline Sample & D band position $\left(\mathbf{c m}^{-\mathbf{1}}\right)$ & $\mathbf{G}$ band position $\left.\mathbf{( c m}^{-\mathbf{1}}\right)$ & $\boldsymbol{I}_{\boldsymbol{D}} / \boldsymbol{I}_{\boldsymbol{G}}$ Intensity ratio \\
\hline Pristine MWCNTs & 1341 & 1571 & 0.457 \\
\hline 6h cut MWCNTs & 1346 & 1580 & 0.817 \\
\hline
\end{tabular}


Table S2: CPO-MWCNT conjugates immobilization data and kinetics.

\begin{tabular}{|c|c|c|}
\hline Parameter & $\begin{array}{c}\text { CPO-MWCNT } \\
\text { (covalent) }\end{array}$ & $\begin{array}{c}\text { CPO-MWCNT } \\
\text { (physical) }\end{array}$ \\
\hline $\begin{array}{c}\text { Loading } \\
\text { (mg protein/mg } \\
\text { nanosupport) }\end{array}$ & $0.07 \pm 0.02$ & $0.10 \pm 0.02$ \\
\hline $\begin{array}{c}\text { Percentage of } \\
\text { enzyme offered }(\%)\end{array}$ & 14 & 20 \\
\hline $\begin{array}{c}\text { Specific Retained } \\
\text { Activity }(\%)\end{array}$ & $52.70 \pm 6.26$ & $41.36 \pm 6.65$ \\
\hline $\begin{array}{c}\mathrm{V}_{\max } \\
\left(\mu \mathrm{M} \mathrm{g}^{-1} \mathrm{~s}^{-1}\right)\end{array}$ & $12.79 \pm 1.97$ & $12.28 \pm 2.56$ \\
\hline $\begin{array}{c}\mathrm{K}_{\mathrm{m}} \\
\left(\mu \mathrm{M} \mathrm{H}_{2} \mathrm{O}_{2}\right)\end{array}$ & $530 \pm 60$ & $340 \pm 70$ \\
\hline $\mathrm{K}_{\mathrm{cat}}\left(\mathrm{s}^{-1}\right)$ & $537.18 \pm 82.74$ & $515.76 \pm$ \\
& & 107.52 \\
\hline$\eta$ & 0.47 & 0.45 \\
\hline
\end{tabular}


Table S3: GOx-MWCNT conjugates immobilization data and kinetics.

\begin{tabular}{|c|c|c|}
\hline Parameter & $\begin{array}{c}\mathrm{GO}_{\mathrm{X}}-\mathrm{MWCNT} \\
(\text { covalent })\end{array}$ & $\begin{array}{c}\mathrm{GO}_{\mathrm{X}}-\mathrm{MWCNT} \\
\text { (physical) }\end{array}$ \\
\hline $\begin{array}{c}\text { Loading } \\
\text { manosupport })\end{array}$ & $0.25 \pm 0.02$ & $0.24 \pm 0.02$ \\
\hline $\begin{array}{c}\text { Percentage of } \\
\text { enzyme offered }(\%)\end{array}$ & 50 & 48 \\
\hline $\begin{array}{c}\text { Specific Retained } \\
\text { Activity }(\%)\end{array}$ & $37.67 \pm 4.70$ & $9.89 \pm 3.30$ \\
\hline $\begin{array}{c}\mathrm{V}_{\max } \\
\left(\mu \mathrm{Mg}^{-1} \mathrm{~s}^{-1}\right)\end{array}$ & $0.196 \pm 0.032$ & $0.029 \pm 0.003$ \\
\hline $\begin{array}{c}\mathrm{K}_{\mathrm{m}} \\
\left(\mu \mathrm{M}_{\mathrm{glucose})}\right.\end{array}$ & $3,200 \pm 700$ & $1,800 \pm 800$ \\
\hline $\mathrm{K}_{\mathrm{cat}}\left(\mathrm{s}^{-1}\right)$ & $31.36 \pm 5.12$ & $4.64 \pm 0.48$ \\
\hline$\eta$ & 0.40 & 0.06 \\
\hline
\end{tabular}

Table S4: CPO-MWNT-GO ${ }_{\mathrm{X}}$ conjugates stability data

\begin{tabular}{|c|c|c|c|c|}
\hline $\begin{array}{c}\text { Storage } \\
\text { Temperature } \\
\left({ }^{\circ} \mathrm{C}\right)\end{array}$ & $\begin{array}{c}\text { Immobilization } \\
\text { Method }\end{array}$ & $\begin{array}{c}\text { Rate after } 1 \\
\text { Week } \\
(\% \text { of original })\end{array}$ & $\begin{array}{c}\text { Rate after } 2 \\
\text { Weeks } \\
(\% \text { of original })\end{array}$ & $\begin{array}{c}\text { Rate after } 4 \\
\text { Weeks } \\
(\% \text { of original })\end{array}$ \\
\hline 4 & $\begin{array}{c}\text { CPO covalent } \\
\mathrm{GO}_{X} \text { physical }\end{array}$ & $80.50 \pm 2.77$ & $58.41 \pm 9.73$ & $51.22 \pm 7.32$ \\
\hline 4 & $\begin{array}{l}\mathrm{GO}_{X} \text { covalent } \\
\text { CPO physical }\end{array}$ & $98.86 \pm 3.54$ & $96.29 \pm 3.71$ & $71.02 \pm 9.50$ \\
\hline 23 & $\begin{array}{l}\text { CPO covalent } \\
\text { GO } \text { physical }\end{array}$ & $52.12 \pm 12.11$ & $26.04 \pm 10.66$ & $39.23 \pm 17.18$ \\
\hline 23 & $\begin{array}{l}\mathrm{GO}_{X} \text { covalent } \\
\mathrm{CPO} \text { physical }\end{array}$ & $68.94 \pm 16.82$ & $54.08 \pm 16.31$ & $39.45 \pm 11.53$ \\
\hline
\end{tabular}




\title{
Effects of acid treatment on structure, properties and biocompatibility of carbon nanotubes
}

\author{
Chenbo Dong a , Alan S. Campell ${ }^{a}$, Reem Eldawud ${ }^{a}$, Gabriela Perhinschi ${ }^{a}$, \\ Yon Rojanasakul ${ }^{\mathrm{b}}$, Cerasela Zoica Dinu ${ }^{\mathrm{a}, *}$ \\ a Department of Chemical Engineering, West Virginia University, Morgantown, WV 26506, USA \\ ${ }^{\mathrm{b}}$ Department of Basic Pharmaceutical Sciences, West Virginia University, Morgantown, WV 26506, USA
}

\section{A R T I C L E I N F O}

\section{Article history:}

Received 28 July 2012

Received in revised form

25 September 2012

Accepted 28 September 2012

Available online 23 October 2012

\section{Keywords:}

Nanotubes

Acid treatment

Structure modification

Cytotoxicity

Biocompatibility

\begin{abstract}
A B S T R A C T
Carbon nanotubes (CNTs) are promising to be the next generation of viable tools for bioapplications Further advances in such bioapplications may depend on improved understanding of CNTs physical and chemical properties as well as control over their biocompatibility. Herein we performed a systematic study to show how acid oxidation treatment changes CNTs physical and chemical properties and leads to improved CNTs biocompatibility. Specifically, by incubating CNTs in a strong acid mixture we created a user-defined library of CNTs samples with different characteristics as recorded using Raman energy dispersive X-ray spectroscopy, atomic force microscopy, or solubility tests. Systematically characterized CNTs were subsequently tested for their biocompatibility in relation to human epithelial cells or enzymes. Such selected examples are building pertinent relationships between CNTs biocompatibility and their intrinsic properties by showing that acid oxidation treatment lowers CNTs toxicity providing feasible platforms to be used for biomedical applications or the next generation of biosensors.
\end{abstract}

(c) 2012 Elsevier B.V. All rights reserved.

\section{Introduction}

Carbon nanotubes (CNTs) are nanoscale diameter materials of tubular shape and micrometer length with many interesting properties that make them viable candidates for a wide range of applications including electrical circuits [1], hydrogen storage [2], fiber optics [3], and conductive plastics [4]. In recent years, CNTs functionalization with biomolecules such as proteins [5], enzymes [6,7] or nucleic acids [8] opened up exciting bioapplications in biolabeling [9], biosensing [10], drug delivery [11], bioseparation [12] and tissue engineering [13]. However, further development of such bioapplications is hindered by: (1) CNT's limited available surface area for biomolecule functionalization [14], (2) lack of understanding of CNTs growth mechanisms in uncontaminated forms [15], (3) CNTs structural instability since larger nanotubes are prone to kinking and collapsing [16,17], and (4) CNTs cytotoxicity and associated health risks posed during their manufacturing and processing [18]. These challenges are mainly associated with the fact that as-produced CNTs form large aggregates in liquid

\footnotetext{
* Corresponding author at: Department of Chemical Engineering, West Virginia University, Benjamin M. Statler College of Engineering and Mineral Resources, PO Box 6102, Morgantown, WV 26506, USA. Tel.: +1 304293 9338; fax: +1 3042934139 .

E-mail address: cerasela-zoica.dinu@mail.wvu.edu (C.Z. Dinu).
}

enviroments since their hydrophobic walls are prone to van der Waals interactions [19]. Thus, in order to increase CNTs bioapplications [20] and reduce their aggregation [21] and cytotoxicity [22], it is critical to overcome their intrinsic hydrophobicity and tendency to form conglomerates in solution.

Numerous attempts have been made to overcome CNTs hydrophobicity and increase their hydrophilicity; these include gas- [23] and liquid-phase activation [24], and oxidation with strong oxidants including hydrogen peroxide [25], potassium permanganate [26], potassium hydroxide [27], and nitric and/or sulfuric acid $[6,7,28]$. Among these attempts, nitric and sulfuric acid oxidation is regarded as the most prevalent treatment since it is easy to implement in both laboratory and industrial settings [20]. When CNTs are oxidized with such aggressive acids, their hydrophilicity is increased by the introduction of oxygencontaining functional groups, i.e., carboxyl [29], carbonyl [26,29], and phenol groups [30]. Moreover, during such oxidation treatments amorphous carbon [31] and residual metal catalyst particles are removed, possibly resulting in reduced intrinsic toxicity of CNTs [22]. Despite the fact that wide evaluations of the effects of acid oxidation on CNTs have been carried out, systematic investigations of changes in physical and chemical properties and how such changes can be further employed for increasing CNTs biocompatibility and thus bioapplications are still lacking.

Herein we performed a systematic study of the changes in physical and chemical properties of pristine CNTs upon user-controlled 
treatment with nitric and sulfuric acids. Further, we assessed how these changes affect CNTs biocompatibility in relation to cellular and enzymatic systems $[6,7,10]$. Our hypothesis was that selected biological examples will help build pertinent relationships between CNTs biocompatibility and their intrinsic properties and demonstrate how interface reactions between a biological molecule and the nanomaterial can be further used to provide systems with lower toxicity to be used for selected bioapplications as well as feasible platforms for the next generation of biosensors.

\section{Materials and methods}

\subsection{Acid oxidation of CNTs}

Acid oxidation treatment of single- and multi-walled carbon nanotubes (SW- and MWCNTs, respectively) was employed to generate a library of samples with different physical and chemical properties. Specifically, commercial SWCNTs (85\% purity, Unidym Inc.) and MWCNTs (95\% purity, Nanolab Inc. (PD15L5-20)) were incubated in a concentrated sulfuric (96.4\%, Fisher, USA) and nitric acid $(69.5 \%$, Fisher, USA) mixture in a ratio of $3: 1(\mathrm{~V} / \mathrm{V})$. The CNTs/acids mixture (where CNTs can refer to either SW- or MWCNTs) was subsequently sonicated in an ice bath (Branson 2510, Fisher, USA) for 1,3 , or $6 \mathrm{~h}$, at a constant temperature of $23^{\circ} \mathrm{C}$. When the required time elapsed, CNTs/acids mixture was diluted with deionized (di) water and filtered through a GTTP $0.2 \mu \mathrm{m}$ polycarbonate filter membrane (Fisher, USA). Several cycles of resuspension in di water were employed to remove acidic residues or catalysts. The CNTs were isolated on the filter, subsequently dried in a vacuum desiccator and stored at room temperature for further use.

\subsection{Energy dispersive X-ray analysis (EDX) of CNTs}

Energy dispersive X-ray analysis (EDX) was used for quantitative elemental analysis of pristine and acid oxidized CNTs. Samples $(1 \mathrm{mg} / \mathrm{ml}$ in di water) were deposited on silica wafers and dried under vacuum. The experiments were performed on a Hitachi S4700 Field Emission Scanning Electron Microscope (USA) with a S-4700 detector combining secondary (SE) and backscattered (BSE) electron detection (all in a single unit), operating at $20 \mathrm{kV}$. Results are presented as a percent of elements relative to the most dominant element.

\subsection{Scanning Electron Microscopy (SEM) of CNTs}

Samples $(1 \mathrm{mg} / \mathrm{ml}$ in di water of both pristine and acid treated CNTs) were dried on silica wafers under vacuum and imaged using a Hitachi S-4700 Field Emission Scanning Electron Microscope (USA) with a field emission at $10 \mathrm{kV}$.

\subsection{Raman spectroscopy of CNTs}

Raman spectroscopy (performed on a Renishaw InVia Raman Spectrometer, CL532-100, $100 \mathrm{~mW}$, USA) allowed determination of the chemical structure and any modifications resulted from the acids oxidation of both pristine and acids treated CNTs. Briefly, CNTs deposited on glass slides (Fisher, USA) were excited through a $20 \times$ microscope objective using an Argon ion $\left(\mathrm{Ar}^{+}\right)$laser beam with a spot size of $<0.01 \mathrm{~mm}^{2}$ operating at $514.5 \mathrm{~nm}$. Detailed scans were taken in the $100-3200 \mathrm{~cm}^{-1}$ range; low laser energy (i.e., $<0.5 \mathrm{mV}$ ) and exposure time of $10 \mathrm{~s}$ were used to prevent unexpected heating effects.

\subsection{CNTs solubility measurement}

The solubility of CNTs (pristine and acids oxidized) was evaluated in di water ( $\mathrm{pH}$ 6.25) and Phosphate Saline Buffer (PBS, pH 7, $100 \mathrm{mM}$ ionic strength). Briefly, CNTs were diluted in the solvent of interest to yield to a $3 \mathrm{mg} / \mathrm{ml}$ solution. The suspension was then centrifuged at $3000 \mathrm{rpm}$ for $5 \mathrm{~min}$; subsequently, part of the supernatant $(0.8 \mathrm{ml})$ was removed and filtered through a $0.2 \mu \mathrm{m}$ GTTP filter membrane. The filter membrane was then dried under vacuum and the amount of CNTs was weighted. The solubility of the CNTs was calculated based on the volume used for suspension and the initial starting amount.

\subsection{CNTs length measurement}

An atomic force microscope (AFM, Asylum Research, USA) was used to evaluate the length of pristine and acids treated CNTs. A Si tip (Asylum Research, 50-90 kHz AC240TS, USA) helped perform tapping mode in air. CNTs samples (i.e., pristine, 1, 3 or $6 \mathrm{~h}$ acids oxidized SW and MWCNTs) were dispersed in di water (to yield solutions of $0.1 \mathrm{mg} / \mathrm{ml}$ concentration), deposited on mica surfaces (9.5 mm diameter, 0.15-0.21 mm thickness, Electron Microscopy Sciences, USA) and allowed to dry over night under vacuum. Scan images of 10,5 or $1(\mu \mathrm{m} \times \mu \mathrm{m})$ areas were acquired. For each sample, at least 30 individual CNTs were counted and measured to obtain average length distribution.

\subsection{Cell culture and treatment with CNTs}

Non-tumorigenic human bronchial epithelial cells (BEAS-2B) were purchased from American Type Culture Collection (ATCC, USA). The cells were cultured in DMEM medium supplemented with $5 \%$ fetal bovine serum (FBS), $2 \mathrm{mM}$ L-glutamine and 100 units/ml penicillin/streptomycin (all reagents were purchased from Invitrogen, USA). Cells were passaged weekly using $0.05 \%$ trypsin (Invitrogen, USA) and kept in $5 \% \mathrm{CO}_{2}$ at $37^{\circ} \mathrm{C}$.

Pristine and acids oxidized SWCNTs were dispersed in di water by sonication, filtered through the $0.2 \mu \mathrm{m}$ GTTP filter membrane, resuspended in cellular media and sonicated at room temperature to form stable dispersions. For treatment, BEAS-2B cells were seeded overnight in a 12 well plates (Fisher, USA) at a density of 3.5E5 cells/well, and allowed to reach confluence. Subsequently, the cells were exposed to $100 \mu \mathrm{g} / \mathrm{ml}$ SWCNTs; $24 \mathrm{~h}$ post exposure, the cells were incubated with $6.5 \mu \mathrm{g} / \mathrm{ml}$ Hoechst 33342 dye (Molecular Probes, USA) for $30 \mathrm{~min}$ at $37^{\circ} \mathrm{C}$ and analyzed for apoptosis by scoring the percentage of cells with intensely condensed chromatin and/or fragmented nuclei using fluorescence microscopy (Leica Microsystems, USA). Approximately 1000 cell nuclei from ten random fields were analyzed for each sample. The apoptotic index was calculated as the percentage of cells with apoptotic nuclei relative to the total number of cells. At least 3 independent trials were performed for each sample.

\subsection{Functionalization of CNTs with enzyme}

Soybean peroxidase (SBP, Bioresearch, USA) was covalently attached to 1,3 or $6 \mathrm{~h}$ acid treated MWCNTs using 1-ethyl-3[3-dimethylaminopropyl] carbodiimide hydrochloride (EDC; Acros Organics, USA) and N-hydroxysuccinimide (NHS, Pierce, USA) [32]. Briefly, $2 \mathrm{mg}$ CNTs (MWCNTs) were dispersed in $160 \mathrm{mM}$ EDC and $80 \mathrm{mM}$ NHS (total volume of $2 \mathrm{ml}$ in MES (2-(Nmorpholino)ethanesulfonic acid sodium salt, $50 \mathrm{mM}, \mathrm{pH}$ 4.7, Sigma, USA) for $15 \mathrm{~min}$ at room temperature with shaking at $200 \mathrm{rpm}$. The activated MWCNTs were next filtered through the $0.2 \mu \mathrm{m}$ GTTP filter membrane, washed thoroughly with MES buffer to remove any ester residues, immediately dispersed in $2 \mathrm{ml}$ of $1 \mathrm{mg} / \mathrm{ml} \mathrm{SBP}$ 
solution in PBS (100 mM, pH 7.0) and incubated for $3 \mathrm{~h}$ at room temperature at room temperature with shaking at $200 \mathrm{rpm}$. The resulting SBP-MWCNT conjugates were filtered and washed extensively with PBS to remove any unbound enzyme [32]. The supernatants and washes were collected to quantify enzyme loading.

\subsection{Enzyme loading}

The amount of SBP attached to MWCNTs (i.e., SBP loading) was determined using standard BCA assay kit (Pierce, USA) and subtracting the amount of enzyme washed out in the supernatant and washes from the amount of SBP initially added to the MWCNTs. Briefly, the working reagent $(1000 \mu \mathrm{l})$ was prepared by mixing 50 parts of reagent $A$ with 1 part of reagent $B$ (the reagents are provided with the kit). The mixture of reagents $A$ and $B$ was further added to $50 \mu$ l solutions of SBP-containing samples (i.e., the samples isolated in the form of the supernatant and washes). The resulting solutions were incubated at $37^{\circ} \mathrm{C}$ for $30 \mathrm{~min}$. Absorbance at $562 \mathrm{~nm}$ was determined on a spectrophotometer (Fisher, USA). Control calibration curves were prepared by serial dilutions of SBP (free in solution) into the working reagent.

\subsection{Enzyme activity assay}

The activity of SBP was measured by monitoring the oxidation reaction of (2,2'-Azinobis [3-ethylbenzothiazoline-6-sulfonic acid]) (ABTS, Sigma, USA) in the presence of hydrogen peroxide $\left(\mathrm{H}_{2} \mathrm{O}_{2}\right.$, Sigma, USA). $20 \mu \mathrm{l}$ of the SBP-MWCNTs conjugates were added to $0.65 \mathrm{ml}$ ABTS solution $(0.5 \mathrm{mM}$ final concentration, Pierce, USA) and mixed; subsequently, $20 \mu \mathrm{H}_{2} \mathrm{O}_{2}$ solution ( $0.2 \mathrm{mM}$ final concentration) was added to the sample in order to initiate the reaction. The change in absorbance was monitored spectrophotometrically at $412 \mathrm{~nm}$ immediately upon addition of $\mathrm{H}_{2} \mathrm{O}_{2}$. The initial reaction rate was calculated from the slope of the linear timecourse. The extinction coefficient of the oxidized ABTS product is $32,400 \mathrm{M}^{-1} \mathrm{~cm}^{-1}$ at $412 \mathrm{~nm}$ [33]. The activity of the immobilized enzyme is reported as specific activity relative to free enzyme activity. The activity of the free enzyme was determined using an equivalent amount of free enzyme (based on loading data) and the protocol provided above.

\subsection{Statistical analysis}

All results are presented as mean \pm standard deviation.

\section{Results and discussion}

We prepared a library of single- and multi-walled carbon nanotubes (SW- and MWCNTs) using liquid phase oxidation with a strong nitric and sulfuric acids mixture [6,7]. The approach is shown in Scheme 1; sonication in the acids mixture attacks the graphene sheets on the $\mathrm{C}-\mathrm{C}$ bands [34], introduces defects and oxidizes the CNTs at the defect sites leading to shorter nanotubes. To reduce the reaction rate of acids attack, the water bath sonicator was maintained at room temperature. The carboxylic acidic groups introduced in SW-and MWCNTs were determined previously using acid-base titrations $[35,36]$ or the formation of a dodecylamine zwitterions [37].

We further investigated the chemical composition of pristine and acids oxidized CNTs using energy dispersive X-ray analysis (EDX) $[20,38]$. EDX spectra of pristine SW- and MWCNTs are shown in Fig. 1a and b, respectively, as a plot of X-ray counts vs. energy (in $\mathrm{keV}$ ). The analysis revealed the presence of high contents of carbon (C) and oxygen (O), with iron (Fe) as metal catalyst in both pristine SW- and MWCNTs samples. The energy peaks correspond to the various elements in the sample, with Fe yielding two peaks at $0.70 \mathrm{keV}$ and $6.40 \mathrm{keV}$ [39]. Other elements (e.g., Al, Si, Cl, S, etc.) were also present but in very low amount. The Fe peak was larger for the SWCNTs sample when compared to the MWCNTs one. The difference was reflective of their pristine characteristics since SWCNTs purity was $85 \%$ while the purity of pristine MWCNTs was $95 \%$, per manufacturer information (see Section 2). The insets in Fig. 1 show the changes in the $\mathrm{O}$ and Fe contents with the acids oxidation treatment time for both SW- and MWCNTs samples. As shown, Fe content decreased with the treatment time for both SW- and MWCNTs samples indicating removal of the metal catalyst. The decrease in the Fe content was more pronounced for the SWCNTs when compared to MWCNTs samples. This is a reflection of the different purities of the two samples chosen in these experiments. For the $\mathrm{O}$ content, the change was also dependent on the sample characteristics. The relative low purity SWCNTs samples contain more amorphous carbon [40] than the higher purity MWCNTs [41]. Thus, the acids treatment led to a significant increase of the $O$ content with the acids treatment time for the SWCNTs (Fig. 1a, inset) when compared to a smaller increase for the MWCNTs samples.

Fig. 2 shows the SEM images of the pristine and acids treated samples (both SW- and MWCNTs). As shown, user-controlled acids treatment did not lead to significant morphological changes either for SW- (Fig. 2a shows pristine SWCNTs while Fig. 2c shows $6 \mathrm{~h}$ acids treated SWCNTs) or MWCNTs (Fig. 2c shows pristine MWCNTs while Fig. 2d shows 6 h treated MWCNTs) samples.

The structural changes upon acids treatment of the CNTs samples were investigated using Raman resonance spectroscopy [42-44]. Fig. 3 shows the Raman spectra of pristine and acids treated SW- and MWCNTs. The Raman analysis of the SWCNTs reveals the presence of 4 bands (Fig. 3a), the so-called D (disorder mode) band around $1340 \mathrm{~cm}^{-1}, \mathrm{G}^{-}$and $\mathrm{G}^{+}$bands at around $1545 \mathrm{~cm}^{-1}$ and $1590 \mathrm{~cm}^{-1}$ respectively, and $\mathrm{G}^{\prime}$ band at $2650 \mathrm{~cm}^{-1}$ $[22,45]$. The Raman analysis of the MWCNTs also reveals the presence of 4 bands (Fig. 3b), with the D band around $1340 \mathrm{~cm}^{-1}, \mathrm{G}$ band at $1585 \mathrm{~cm}^{-1}, \mathrm{G}^{\prime}$ band at $2650 \mathrm{~cm}^{-1}$, and another band at $2920 \mathrm{~cm}^{-1}[46,47]$. The $D$ band around $1340 \mathrm{~cm}^{-1}$ is related to the non-crystalline $C$ species, i.e., defects in the CNTs [48], while the $\mathrm{G}$ band observed around $1585 \mathrm{~cm}^{-1}$ is indicative of a high degree of ordering and well-structured C-based structures [42]. The size of the $\mathrm{D}$ band relative to the $\mathrm{G}$ band can be used as a qualitative measurement for the formation of undesired forms of $C$ [49]. Both pristine and acids treated CNTs (SW- and MWCNTs) have a relatively small $\mathrm{D}$ band at around $1350 \mathrm{~cm}^{-1}$, with the $\mathrm{D}$ band being wider and shifted toward higher frequency in the acids treated

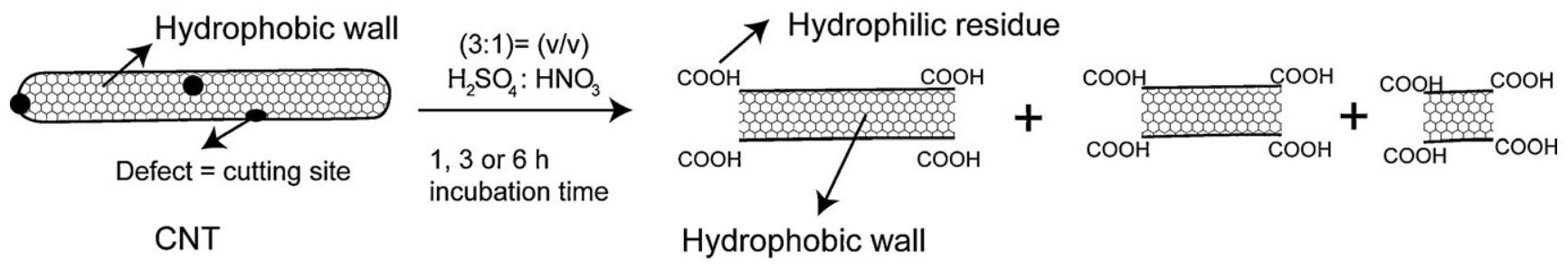

Scheme 1. Time-dependent incubation of pristine CNTs (SW- and MWCNTs) with a mixture of sulfuric and nitric acids leads to acids oxidized CNTs. 


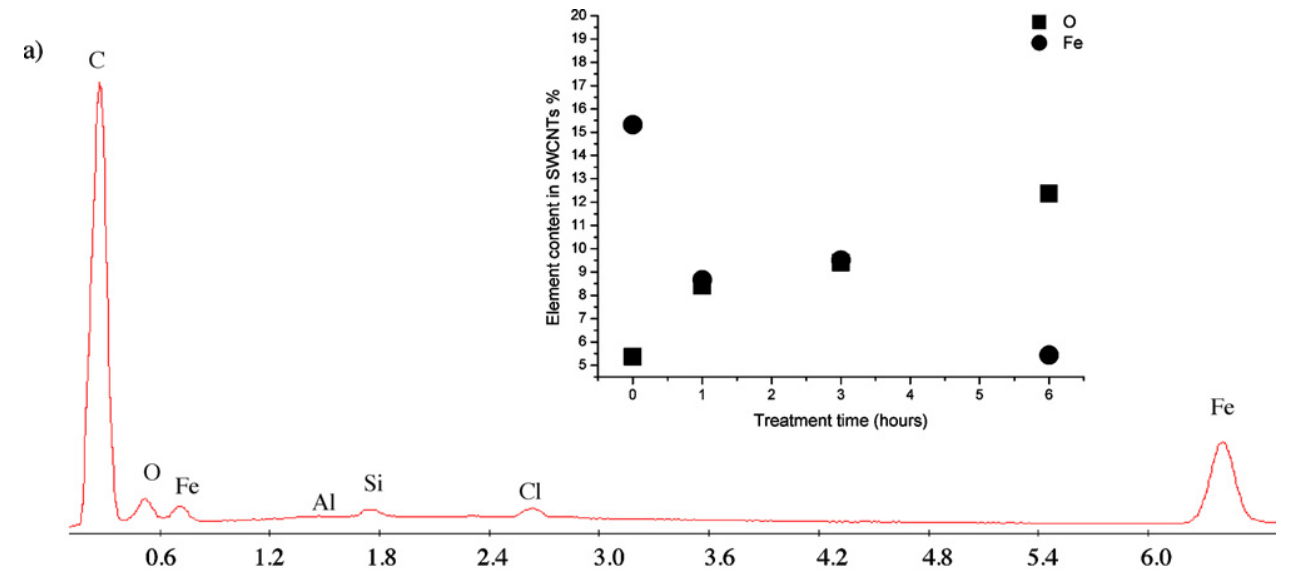

b)

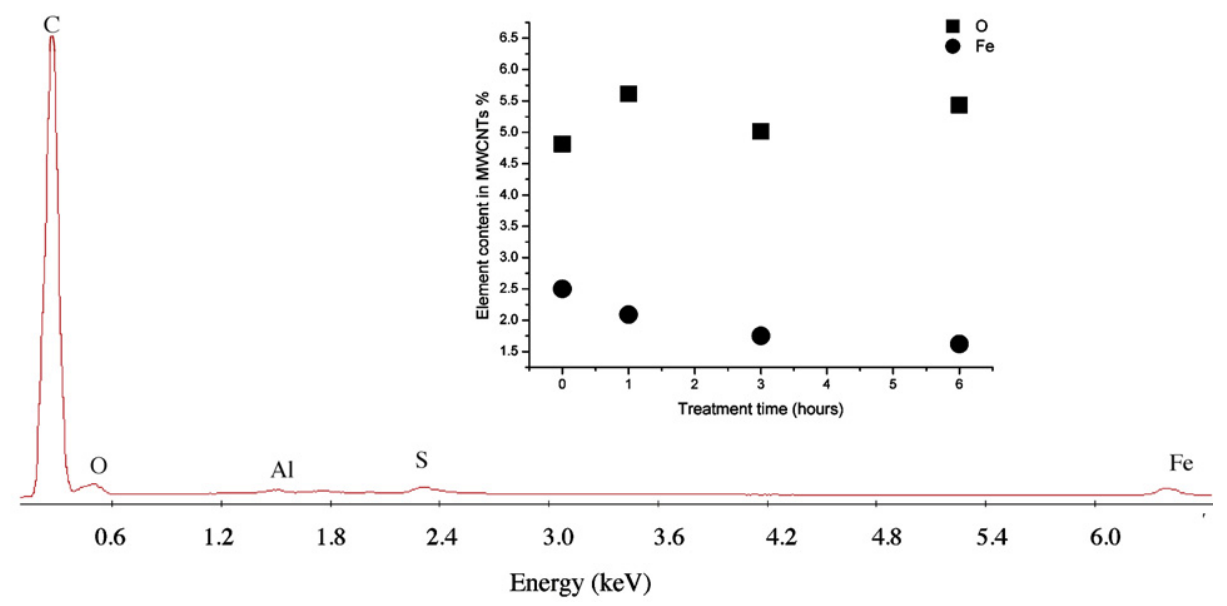

Fig. 1. EDX elemental analysis of pristine SWCNTs (a) and MWCNTs (b). The insets show the changes in the $\mathrm{O}$ and Fe contents with the acids treatment time employed under user-control.

samples when compared with the pristine ones. The ratio of intensity of $D$ peak relative to the $G$ peak represents the degree of CNTs functionalization [49]. Higher $I_{\mathrm{D}} / I_{\mathrm{G}}$ ratio suggests higher level of functionalization ( $I$ represents the peak's relative intensity).

$\mathrm{D}$ band, $\mathrm{G}$ band and $I_{\mathrm{D}} / I_{\mathrm{G}}$ ratio of the various CNTs samples (both SW- and MWCNTs) are shown in Table 1 . The ratio of $I_{\mathrm{D}} / I_{\mathrm{G}}$ for SWCNTs changed minimally from 0.237 for pristine to 0.263 after $6 \mathrm{~h}$ acid treatment. For 1 and $3 \mathrm{~h}$ acid oxidized SWCNTs, the $I_{\mathrm{D}} / I_{\mathrm{G}}$ ratio seemed to have decreased. Previous reports have shown that for relatively low purity CNTs (in this particular example the SWCNT's purity is $85 \%$; see Section 2 ) the $I_{\mathrm{D}} / I_{\mathrm{G}}$ does not provide precise overall information on the sample structure [50], and the $I_{\mathrm{D}} / I_{\mathrm{G}}$ ratio might be both a reflection of washing away amorphous carbon while simultaneously inducing carboxylic acid groups [20].

Table 1

Relative intensity of representative Raman peaks of pristine and acids treated CNTs.

\begin{tabular}{llll}
\hline CNT & $\begin{array}{l}\text { D band position } \\
\left(\mathrm{cm}^{-1}\right)\end{array}$ & $\begin{array}{l}\text { G band position } \\
\left(\mathrm{cm}^{-1}\right)\end{array}$ & $\begin{array}{l}\text { ID/IG intensity } \\
\text { ratio }\end{array}$ \\
\hline $\begin{array}{l}\text { Pristine SWCNTs } \\
\text { 1 h cut SWCNTs }\end{array}$ & 1328 & 1590 & 0.237 \\
3 h cut SWCNTs & 1333 & 1587 & 0.195 \\
6 h cut SWCNTs & 1336 & 1592 & 0.229 \\
Pristine MWCNTs & 1345 & 1595 & 0.263 \\
1 h cut MWCNTs & 1347 & 1586 & 0.457 \\
3 h cut MWCNTs & 1349 & 1586 & 0.783 \\
6h cut MWCNTs & 1351 & 1586 & 0.788 \\
\hline
\end{tabular}

For instance, in the initial $1 \mathrm{~h}$ SWCNTs acids oxidation, the effect of washing away amorphous $\mathrm{C}$ (which is known to lead to decreased $\left.I_{\mathrm{D}} / I_{\mathrm{G}}[51]\right)$ suppressed the effect of adding carboxylic acid groups (which is known to lead to increased $I_{\mathrm{D}} / I_{\mathrm{G}}[52]$ ). However, after $6 \mathrm{~h}$, most of the amorphous $C$ was removed and the $I_{\mathrm{D}} / I_{\mathrm{G}}$ became indicative only of the degree of functionalization with carboxylic groups.

$I_{\mathrm{D}} / I_{\mathrm{G}}$ for MWCNTs increased from 0.457 for pristine to 0.788 for $3 \mathrm{~h}$, and 0.796 after $6 \mathrm{~h}$ acids oxidation. This increase in the level of functionalization has a similar trend to the increase in the $\mathrm{O}$ or decrease in the Fe catalyst content as observed through the EDX analyses (Fig. 1). Specifically, for the high purity MWCNTs most of the Fe catalysts are removed during the $3 \mathrm{~h}$ treatment time (see inset Fig. 1b) this leading to removal of the defects in the MWCNTs structure. Since defects are where the promotion of the carboxylic groups formation takes place [53], and since for the MWCNTs there was a small decrease in the Fe and a small increase in the $\mathrm{O}$ content (Fig. 1b inset) from the $3 \mathrm{~h}$ to $6 \mathrm{~h}$ treatment time, the $I_{\mathrm{D}} / I_{\mathrm{G}}$ for MWCNTs will be minimally changed between these time points as indicated in Table 1 . Such analyses confirm that the acids oxidation introduced CNTs chemical property changes i.e., added functional free carboxylic acid groups, to both SW- and MWCNTs sample.

We further investigated how the degree of CNTs dispersion in water-based environments is influenced by the acids oxidation time. We used two solvents with different pH's and ionic strengths, i.e., di water ( $\mathrm{pH}$ 6.25) and Phosphate Saline Buffer (PBS, pH 7, $100 \mathrm{mM}$ ). The results (Fig. 4) indicated that the solubility of CNTs 
a

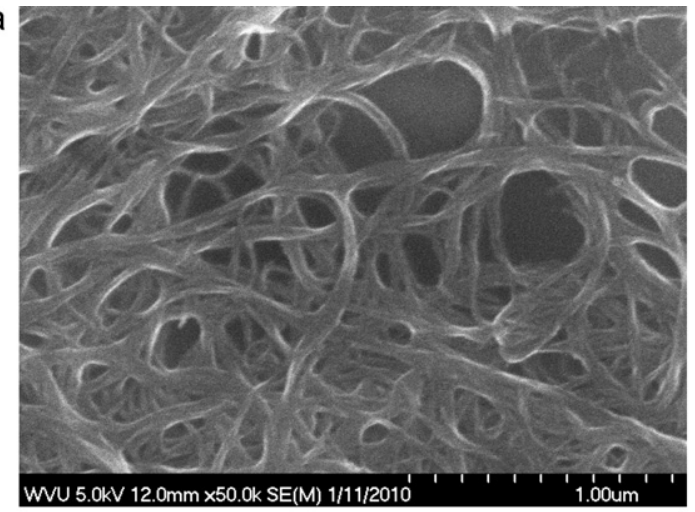

C

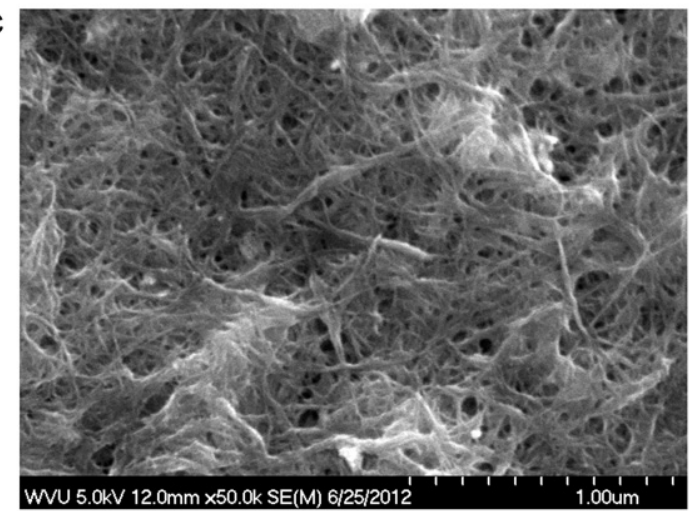

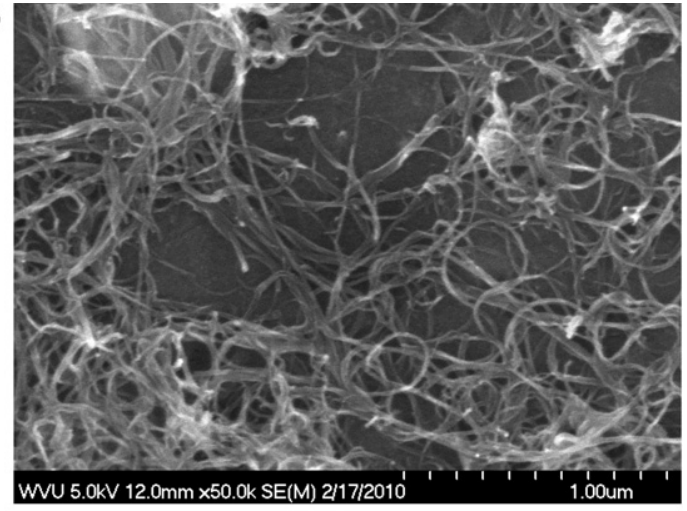

d

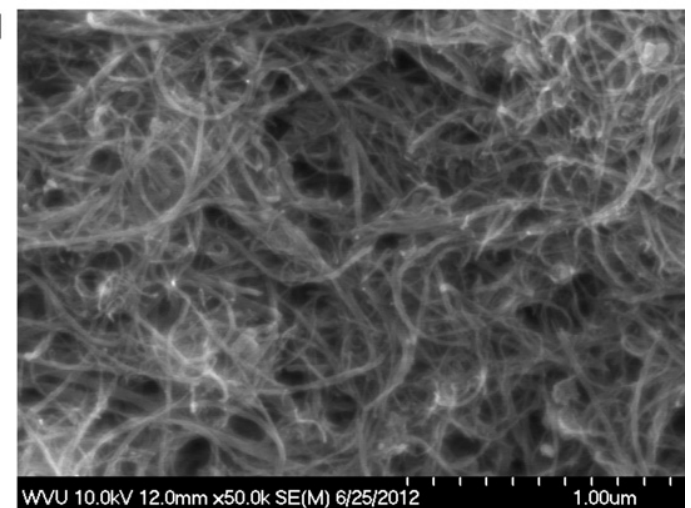

Fig. 2. SEM image of (a) pristine SWCNTs, (b) pristine MWCNTs and (c) $6 \mathrm{~h}$ acids treated SWCNTs (d) $6 \mathrm{~h}$ acids treated MWCNTs; the scale bar is $1 \mu \mathrm{m}$.

in both di water and PBS was improved upon the acids oxidation, with increased acids oxidation times leading to increased solubility. Generally, pristine and acid oxidized SWCNTs (either 1, 3 or $6 \mathrm{~h}$ cut) were more dispersed in PBS when compared to di water (Fig. 4a). MWCNTs did not show a similar trend; specifically, pristine and $1 \mathrm{~h}$ cut MWCNTs were more soluble in PBS, however, after longer acids oxidation times (i.e., 3 and $6 \mathrm{~h}$ ) the solubility was higher in water when compared to PBS (Fig. 4b). The changes in the solubility observed for the MWCNTs samples after longer acids oxidation times are correlated with the changes in the functionality of these samples and number of carboxylic acidic groups being generated. Specifically, longer acids oxidation times will lead to higher number of carboxyl groups being generated (see Figs. 1 and 3).
When the MWCNTs acids treated samples are placed in waterbased environments, carboxylate anions groups are generated by the deprotonation of carboxylic acid groups [54]. At high ionic strength, the probability for these anions to form aggregates [55] increases thus leading to the lower solubility observed for the 3 and $6 \mathrm{~h}$ acids oxidized MWCNTs placed in PBS when compared to solubility of these samples placed in water.

Atomic force microscopy (AFM) and tapping mode [56] was used to analyze the morphology and quantify the length of the CNTs samples. Specifically, cross sectional areas from $(10 \times 10)$ to $(1 \times 1) \mu \mathrm{m} \times \mu \mathrm{m}$ were scanned to derive the length of at least 30 CNTs/sample (both SW- and MWCNTs; pristine, 1, 3 and $6 \mathrm{~h}$ cut). Pristine and acids oxidized CNTs length distributions are shown in
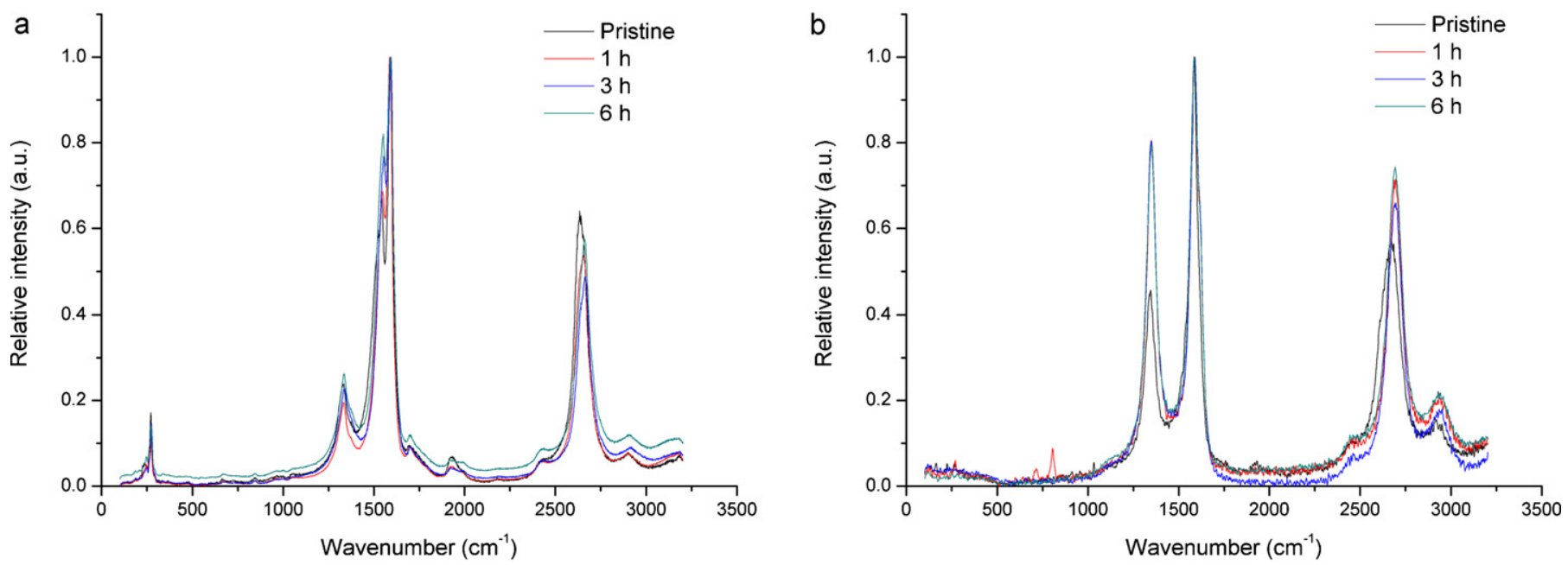

Fig. 3. Raman spectra of pristine, 1,3 and $6 \mathrm{~h}$ acids oxidized SWCNTs (a) and MWCNTs (b). 

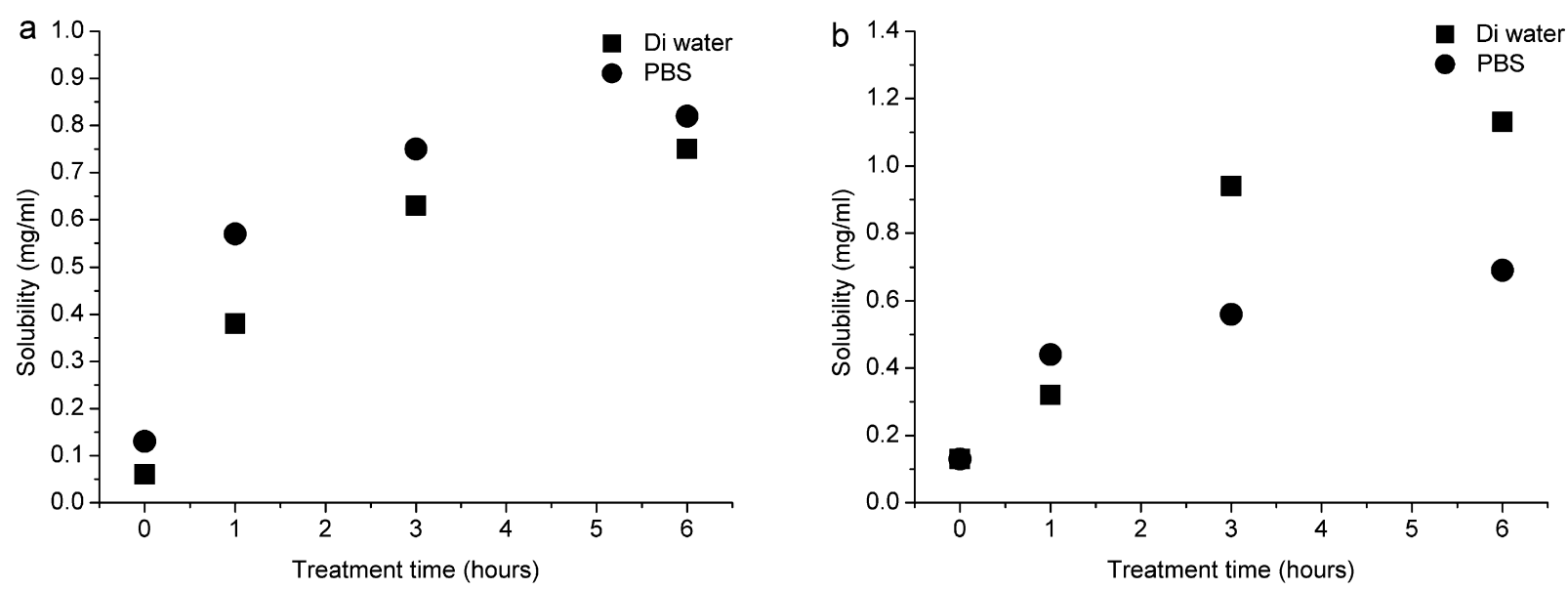

Fig. 4. Solubility of pristine and acids oxidized SWCNTs (a) and MWCNTs (b) in deionized (di) water and phosphate buffer saline (PBS).
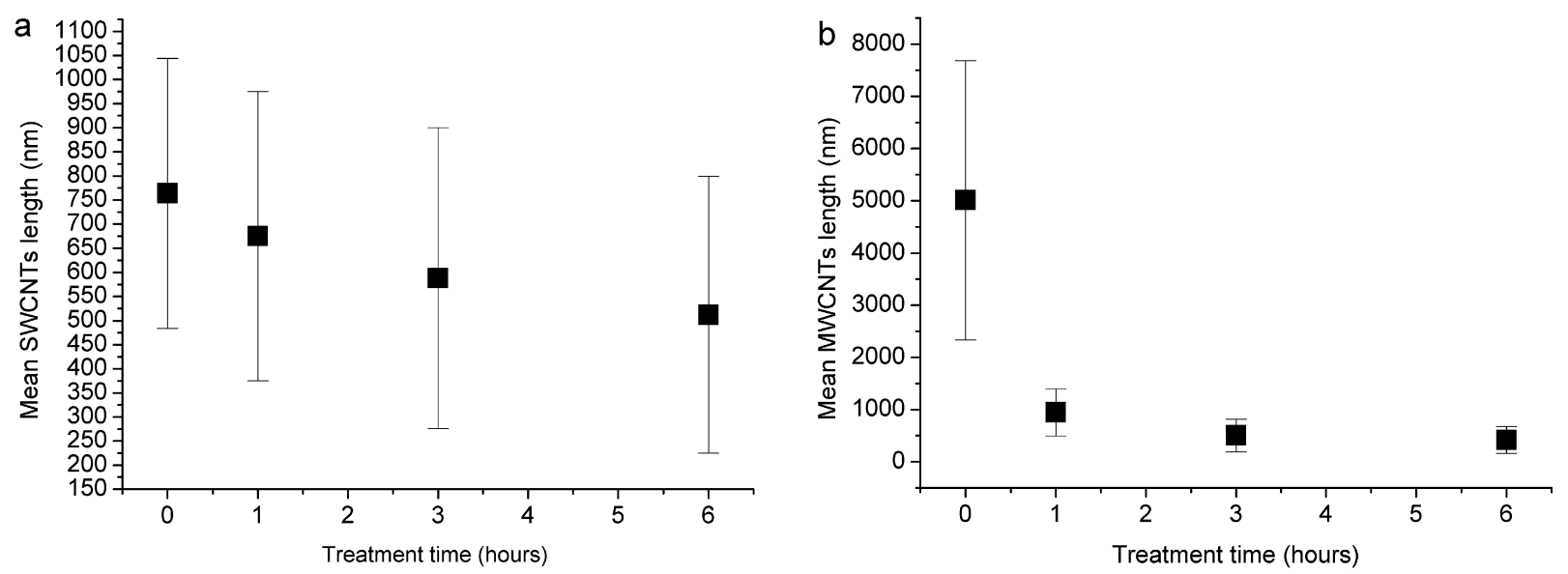

Fig. 5. The average length distribution and the standard deviation of SWCNTs (a) and MWCNTs (b) with the acids treatment time.

Fig. 5; a general non-linear distribution toward shorter CNTs was observed with the increase in the acids oxidation time.

Having established that the acids oxidation influences the chemical and physical properties of pristine CNTs (both SW- and MWCNTs), we proceeded to examine whether user-controlled acids oxidation would also affect CNTs biocompatibility. First, we performed a systematic study on the cellular toxicity resulted from the incubation of immortalized human bronchial epithelial cells with acids oxidized SWCNTs. Previous in vivo studies have shown that cellular exposure to SWCNTs results in macrophages without nuclei $[57,58]$, with SWCNTs inducing chromosome aberration [18]. However, to our knowledge, no studies that looked at the influence of the different acids oxidation times to BEAS-2B immortalized human bronchial epithelial cells have been performed. Moreover, to our knowledge, there is no correlation in the literature on how cellular toxicity depends on the SWCNTs physical and chemical properties as impaired by the acids oxidation time and how such toxicity can be controlled. In our experiments, BEAS-2B cells were exposed to SWCNTs for 24-72 h at Permissible Exposure Limit for particulates not otherwise regulated (i.e., $100 \mu \mathrm{g} / \mathrm{ml}$ of SWCNTs, based on previous laboratory exposure levels [58,59]). Fig. 6 shows the percentage of apoptotic BEAS-2B cells upon exposure to SWCNTs; our data shows that the cytotoxicity of the $6 \mathrm{~h}$ acids treated SWCNTs is lower than that of pristine SWCNTs. Specifically, the percentage of apoptotic cells for pristine SWCNTs is about $19 \%$ while the percentage of apoptotic cells for $6 \mathrm{~h}$ acids treated SWCNTs is about $15 \%$ upon $72 \mathrm{~h}$ incubation. These results are comparable to control cells (cells that have not been exposed to SWCNTs) and they emphasize that user-controlled acids oxidation time can be employed to create a library of sample of SWCNTs that have high biocompatibility with cellular system. We hypothesized that the observed trend is due to the changes in the chemical and physical structure of the SWCNTs upon acid functionalization. Specifically, shorter and more hydrophilic SWCNTs (see our previous EDX and AFM results) would be predominantly taken up by the cells through endocytosis [60], while for the longer SWCNTs the uptake mechanism is predominantly through piercing [61]. Further, the longer SWCNTs once taken up by the cells can localize at the cell nucleus and interfere with the normal progression of cells to

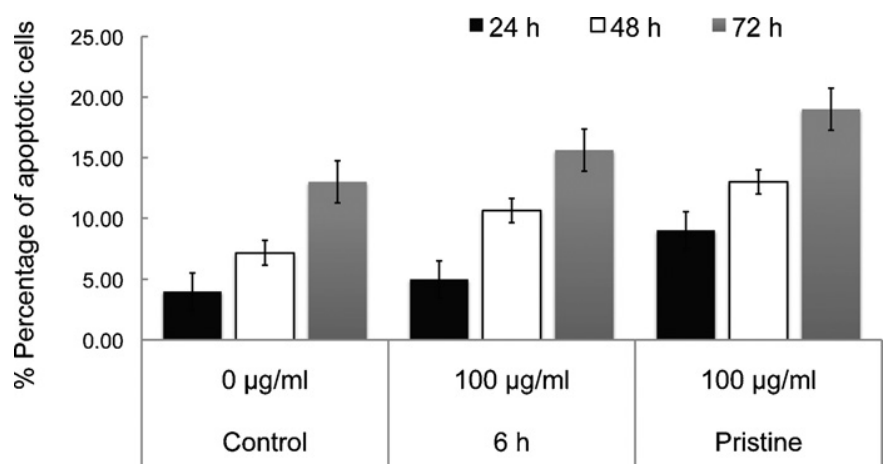

Fig. 6. Cytotoxicity of pristine and $6 \mathrm{~h}$ acids treated SWCNTs to BEAS-2B human epithelial cells after 24,48 and $72 \mathrm{~h}$, respectively. 
Table 2

Loading and retained specific activity of immobilized SBP onto acids treated MWCNTs.

\begin{tabular}{llc}
\hline Sample & $\begin{array}{l}\text { Loading (mg } \\
\text { SBP/mg MWCNTs) }\end{array}$ & $\begin{array}{l}\text { Retained specific } \\
\text { activity (\%) }\end{array}$ \\
\hline 1 h cut covalent & $0.254 \pm 0.05$ & $9.40 \pm 1.68$ \\
3 h cut covalent & $0.282 \pm 0.06$ & $28.18 \pm 6.52$ \\
6 h cut covalent & $0.265 \pm 0.15$ & $33.97 \pm 9.82$ \\
\hline
\end{tabular}

division $[58,60]$ thus leading to the observed results. In the future, such library can be utilized for instance for the cellular delivery of drugs or molecules of interest [11].

Secondly, we tested the biocompatibility of the CNTs in relation to enzyme immobilization. Enzyme immobilization provides enzyme reutilization and eliminates costly enzyme recovery and purification processes. CNTs have high surface area [62] that facilitates the preparation of enzyme-CNTs conjugates with high enzyme loadings per unit weight of material $[63,64]$ and promote protein activity and stability in strongly denaturing environments [63-67]. A test enzyme, namely soybean peroxidase (SBP) was immobilized through covalent binding onto MWCNTs [64,65,68-73]. Table 2 shows the loading (defined as the amount of the enzyme immobilized onto the MWCNTs) and the retained specific activity of the enzyme after immobilization. Our results show that the physical and chemical properties of the CNTs influence the enzyme loading and retained specific activity. The lowest activity was observed for the SBP immobilized onto the $1 \mathrm{~h}$ acids treated MWCNTs, while the activity of SBP immobilized onto 3 and $6 \mathrm{~h}$ acids treated MWCNTs showed similar values. The lower activity observed for the SBP immobilized onto $1 \mathrm{~h}$ acids oxidized MWCNTs can be attributed to the lower solubility of these CNTs (see Fig. 4b). Specifically, lower solubility of the MWCNTs leads to larger conglomerate formation (due to predominant van der Waals interactions between the MWCNTs hydrophobic walls) thus resulting in a lower surface area exposed for immobilization of SBP. Further, SBP (a $40 \mathrm{kDa}$ molecular weight enzyme) has an isoelectric point of 3.9 [74]; thus, at the working PBS's $\mathrm{pH}$, the protein will have a negative charge which will lead to stronger interactions with the more hydrophobic substrates of $1 \mathrm{~h}$ acids treated MWCNTs when compared to the less hydrophobic 3 and $6 \mathrm{~h}$ acids oxidized samples. Stronger binding of the SBP to the substrate will further lead to a reduction in the protein activity $[32,74]$. Such example demonstrated the utility of creating biocompatible MWCNTs nanosupports for biosensors applications [10]; such enzyme-nanosupport-based application can further be employed for decontamination of bacteria and spores [32].

\section{Conclusion}

Our results have shown that user-controlled acid oxidation of CNTs led to the formation of a library of samples with different physical and chemical properties. Specifically, we have shown that CNTs oxidation with a nitric and sulfuric acids mixture results in removal of metal catalyst, an increase in the number of functional groups having electron accepting ability, and generation of shorter CNTs with higher solubility in aqueous environments. Our results were confirmed by Raman spectroscopy, SEM, AFM, EDX and solubility tests. Further, we have shown that CNTs acids oxidation improves nanotube biocompatibility as tested by direct incubation with human epithelial cells or with test enzymes. User-controlled design of CNTs biocompatibility can lead to new types of analytical tools for life science and biotechnology [75-77].

\section{Acknowledgements}

This work is support by the NSF/CBET 1033266 and NSF/EPS1003907. The authors acknowledge Adrienne McGraw, Chemical Engineering/WVU for her help with EDX/SEM analysis and Dr. Weiqiang Ding/WVNano for his help with Raman analysis. Authors acknowledge use of the WVU Shared Research Facilities.

\section{References}

[1] F.F. Shao, T.W. Ng, J. Fu, W. Shen, W.Y.L. Ling, Electrical circuits from capillary flow driven evaporation deposition of carbon nanotube ink in non-porous $\mathrm{V}$ grooves, J. Colloid Interf. Sci. 363 (2011) 425-430.

[2] A. Nikitin, X.L. Li, Z.Y.Zhang, H. Ogasawara, H.J. Dai, A. Nilsson, Hydrogen storage in carbon nanotubes through the formation of stable $\mathrm{C}-\mathrm{H}$ bonds, Nano Lett. 8 (2008) 162-167.

[3] A. Cusano, M. Consales, A. Crescitelli, M. Penza, P. Aversa, C.D. Veneri, M. Giordano, Charge transfer effects on the sensing properties of fiber optic chemical nano-sensors based on single-walled carbon nanotubes, Carbon 47 (2009) $782-788$.

[4] M.H.A. Ng, L.T. Hartadi, H. Tan, C.H.P. Poa, Efficient coating of transparent and conductive carbon nanotube thin films on plastic substrates, Nanotechnology 19 (2008).

[5] B.D. Holt, K.N. Dahl, M.F. Islam, Cells take up and recover from protein-stabilized single-wall carbon nanotubes with two distinct rates, ACS Nano 6 (2012) 3481-3490.

[6] C.Z. Dinu, S.S. Bale, D.B. Chrisey, J.S. Dordick, Manipulation of individual carbon nanotubes by reconstructing the intracellular transport of a living cell, Adv. Mater. 21 (2009) 1182-1186.

[7] C.Z. Dinu, I.V. Borkar, S.S. Bale, A.S. Campbell, R.S. Kane, J.S. Dordick, Perhydrolase-nanotube-paint sporicidal composites stabilized by intramolecular crosslinking, J. Mol. Catal. B-Enzym. 75 (2012) 20-26.

[8] H. Chen, J. Wang, G. Liang, P. Zhang, J. Kong, A novel exonuclease III aided amplification method for sensitive nucleic acid detection based on single walled carbon nanotube induced quenching, Chem. Commun. 48 (2012) 269-271.

[9] D.A. Ho, Beyond the sparkle: the impact of nanodiamonds as biolabeling and therapeutic agents, ACS Nano 3 (2009) 3825-3829.

[10] J.C. Claussen, A.D. Franklin, A. ul Haque, D.M. Porterfield, T.S. Fisher, Electrochemical biosensor of nanocube-augmented carbon nanotube networks, ACS Nano 3 (2009) 37-44

[11] A.A. Bhirde, V. Patel, J. Gavard, G.F. Zhang, A.A. Sousa, A. Masedunskas, R.D. Leapman, R. Weigert, J.S. Gutkind, J.F. Rusling, Targeted killing of cancer cells in vivo and in vitro with EGF-directed carbon nanotube-based drug delivery, ACS Nano 3 (2009) 307-316.

[12] C. Fernandez-Sanchez, E. Pellicer, J. Orozco, C. Jimenez-Jorquera, L.M. Lechuga, E. Mendoza, Plasma-activated multi-walled carbon nanotube-polystyrene composite substrates for biosensing, Nanotechnology 20 (2009).

[13] G. Cellot, E. Cilia, S. Cipollone, V. Rancic, A. Sucapane, S. Giordani, L. Gambazzi, H. Markram, M. Grandolfo, D. Scaini, F. Gelain, L. Casalis, M. Prato, M. Giugliano, L. Ballerini, Carbon nanotubes might improve neuronal performance by favouring electrical shortcuts, Nat. Nanotechnol. 4 (2009) 126-133.

[14] L.L. Ji, Y. Shao, Z.Y. Xu, S.R. Zheng, D.Q. Zhu, Adsorption of monoaromatic compounds and pharmaceutical antibiotics on carbon nanotubes activated by $\mathrm{KOH}$ etching, Environ. Sci. Technol. 44 (2010) 6429-6436.

[15] Y. Kimura, J.A. Nuth, N.M. Johnson, K.D. Farmer, K.P. Roberts, S.R. Hussaini, Synthesis of stacked-cup carbon nanotubes in a metal free low temperature system, Nanosci. Nanotechnol. Lett. 3 (2011) 4-10.

[16] M. Amer, A. Bushmaker, S. Cronin, Anomalous kink behavior in the current-voltage characteristics of suspended carbon nanotubes, Nano Res. 5 (2012) 172-180

[17] J.J. Vilatela, J.A. Elliott, A.H. Windle, A model for the strength of yarn-like carbon nanotube fibers, ACS Nano 5 (2011) 1921-1927.

[18] L.M. Sargent, A.F. Hubbs, S.H. Young, M.L. Kashon, C.Z. Dinu, J.L. Salisbury, S.A Benkovic, D.T. Lowry, A.R. Murray, E.R. Kisin, K.J. Siegrist, L. Battelli, J. Mastovich, J.L. Sturgeon, K.L. Bunker, A.A. Shvedova, S.H. Reynolds, Single-walled carbon nanotube-induced mitotic disruption, Mutat. Res. Genet. Toxicol. Environ. Mutagen 745 (2012) 28-37.

[19] S. Zhang, T. Shado, S.S. Bekaroglu, T. Karanfil, The impacts of aggregation and surface chemistry of carbon nanotubes on the adsorption of synthetic organic compounds, Environ. Sci. Technol. 43 (2009) 5719-5725.

[20] K.A. Wepasnick, B.A. Smith, K.E. Schrote, H.K. Wilson, S.R. Diegelmann, D.H. Fairbrother, Surface and structural characterization of multi-walled carbon nanotubes following different oxidative treatments, Carbon 49 (2011) 24-36.

[21] D.H. Marsh, G.A. Rance, M.H. Zaka, R.J. Whitby, A.N. Khlobystov, Comparison of the stability of multiwalled carbon nanotube dispersions in water, Phys. Chem. Chem. Phys. 9 (2007) 5490-5496.

[22] A.E. Porter, M. Gass, J.S. Bendall, K. Muller, A. Goode, J.N. Skepper, P.A. Midgley, M. Welland, Uptake of noncytotoxic acid-treated single-walled carbon nanotubes into the cytoplasm of human macrophage cells, Acs Nano 3 (2009) 1485-1492.

[23] J.G. Park, S. Li, R. Liang, C. Zhang, B. Wang, Structural changes and Raman analysis of single-walled carbon nanotube buckypaper after high current density induced burning, Carbon 46 (2008) 1175-1183. 
[24] W. Guo, Z.P. Dou, H. Li, Z.J. Shi, H.F. Sun, Y.F. Liu, An efficient strategy for the purification of cloth-like single walled carbon nanotube soot produced by arc discharge, Carbon 48 (2010) 3769-3777.

[25] Z.H. Qu, G.J. Wang, Effective chemical oxidation on the structure of multiwalled carbon nanotubes, J. Nanosci. Nanotechnol. 12 (2012) 105-111.

[26] L.X. Li, F. Li, The effect of carbonyl, carboxyl and hydroxyl groups on the capacitance of carbon nanotubes, New Carbon Mater. 26 (2011) 224-228.

[27] L.F. Chen, H.Q. Xie, Y. Li, A. Yu, Surface chemical modification of multiwalled carbon nanotubes by a wet-mechanochemical reaction, J. Nanomater. 2008 (2008) 1-5, Article ID 783981.

[28] Y.R. Shin, I.Y. Jeon, J.B. Baek, Stability of multi-walled carbon nanotubes in commonly used acidic media, Carbon 50 (2012) 1465-1476.

[29] B. Smith, K. Wepasnick, K.E. Schrote, A.H. Bertele, W.P. Ball, C. O’Melia, D.H. Fairbrother, Colloidal properties of aqueous suspensions of acid-treated, multiwalled carbon nanotubes, Environ. Sci. Technol. 43 (2009) 819-825.

[30] V. Georgakilas, A. Bourlinos, D. Gournis, T. Tsoufis, C. Trapalis, A. Mateo-Alonso, M. Prato, Multipurpose organically modified carbon nanotubes: from functionalization to nanotube composites, J. Am. Chem. Soc. 130 (2008) 8733-8740.

[31] V. Datsyuk, M. Kalyva, K. Papagelis, J. Parthenios, D. Tasis, A. Siokou, I. Kallitsis, C. Galiotis, Chemical oxidation of multiwalled carbon nanotubes, Carbon 46 (2008) 833-840.

[32] C.Z. Dinu, G. Zhu, S.S. Bale, G. Anand, P.J. Reeder, K. Sanford, G. Whited, R.S. Kane, J.S. Dordick, Enzyme-based nanoscale composites for use as active decontamination surfaces, Adv. Funct. Mater. 20 (2010) 392-398.

[33] N.E. Marks, A.S. Grandison, M.J. Lewis, Challenge testing of the lactoperoxidase system in pasteurized milk, J. Appl. Microbiol. 91 (2001) 735-741.

[34] G.A. Forrest, A.J. Alexander, A model for the dependence of carbon nanotube length on acid oxidation time, J. Phys. Chem. C 111 (2007) 10792-10798.

[35] M.A. Hamon, H. Hu, P. Bhowmik, S. Niyogi, B. Zhao, M.E. Itkis, R.C. Haddon, Endgroup, defect analysis of soluble single-walled carbon nanotubes, Chem. Phys. Lett. 347 (2001) 8-12.

[36] H. Hu, P. Bhowmik, B. Zhao, M.A. Hamon, M.E. Itkis, R.C. Haddon, Determination of the acidic sites of purified single-walled carbon nanotubes by acid-base titration, Chem. Phys. Lett. 345 (2001) 25-28.

[37] M.W. Marshall, S. Popa-Nita, J.G. Shapter, Measurement of functionalised carbon nanotube carboxylic acid groups using a simple chemical process, Carbon 44 (2006) 1137-1141.

[38] N. Kulshrestha, A. Misra, K.S. Hazra, S. Roy, R. Bajpai, D.R. Mohapatra, D.S. Misra, Healing of broken multiwalled carbon nanotubes using very low energy electrons in SEM: a route toward complete recovery, ACS Nano 5 (2011)1724-1730.

[39] R. Kozhuharova, M. Ritschel, D. Elefant, A. Graff, A. Leonhardt, I. Monch, T. Muhl, C.M. Schneider, Synthesis and characterization of aligned Fe-filled carbon nanotubes on silicon substrates, J. Mater. Sci.-Mater. Electron. 14 (2003) 789-791.

[40] A. Hirano, T. Tanaka, Y. Urabe, H. Kataura, Purification of single-wall carbon nanotubes by controlling the adsorbability onto agarose gels using deoxycholate, J. Phys. Chem. C 116 (2012) 9816-9823.

[41] A.R. Biris, L.P. Dan, E. Dervishi, Z.R. Li, Y. Xu, S. Trigwell, I. Misan, A.S. Biris, Multiwall carbon nanotubes synthesized by RF-CCVD on novel CaO supported catalysts, Phys. Lett. A 372 (2008) 6416-6419.

[42] M.S. Dresselhaus, A. Jorio, M. Hofmann, G. Dresselhaus, R. Saito, Perspectives on carbon nanotubes and graphene Raman spectroscopy, Nano Lett. 10 (2010) 751-758.

[43] A.K. Mishra, S. Ramaprabhu, Nano magnetite decorated multiwalled carbon nanotubes: a robust nanomaterial for enhanced carbon dioxide adsorption, Energ. Environ. Sci. 4 (2011) 889-895.

[44] C.B. Dong, Z.J. Yan, J. Kokx, C.Z. Dinu, D.B. Chrisey, Antibacterial and surfaceenhanced Raman scattering (SERS) activities of $\mathrm{AgCl}$ cubes synthesized by pulsed laser ablation in liquid, Appl. Surf. Sci. 258 (2012) 9218-9222.

[45] J. Maultzsch, S. Reich, C. Thomsen, S. Webster, R. Czerw, D.L. Carroll, S.M.C. Vieira, P.R. Birkett, C.A. Rego, Raman characterization of boron-doped multiwalled carbon nanotubes, Appl. Phys. Lett. 81 (2002) 2647-2649.

[46] E. Dervishi, Z. Li, A.R. Biris, D. Lupu, S. Trigwell, A.S. Biris, Morphology of multi-walled carbon nanotubes affected by the thermal stability of the catalyst system, Chem. Mater. 19 (2007) 179-184.

[47] C.W. Yang, X.U. Hu, Y. Zhang, A study of the functionalization on multi-walled carbon nanotubes, in: 2006 1st IEEE International Conference on Nano/Micro Engineered and Molecular Systems, vols. 1-3, 2006, pp. 83-86.

[48] M. Kalbac, Y.P. Hsieh, H. Farhat, L. Kavan, M. Hofmann, J. Kong, M.S. Dresselhaus, Defects in individual semiconducting single wall carbon nanotubes: Raman spectroscopic and in situ Raman spectroelectrochemical study, Nano Lett. 10 (2010) 4619-4626.

[49] S. Dittmer, N. Olofsson, J.E. Weis, O.A. Nerushev, A.V. Gromov, E.E.B. Campbell, In situ Raman studies of single-walled carbon nanotubes grown by local catalyst heating, Chem. Phys. Lett. 457 (2008) 206-210.

[50] K.A. Wepasnick, B.A. Smith, J.L. Bitter, D.H. Fairbrother, Chemical and structural characterization of carbon nanotube surfaces, Anal. Bioanal. Chem. 396 (2010) $1003-1014$.

[51] L. Shao, G. Tobias, C.G. Salzmann, B. Ballesteros, S.Y. Hong, A. Crossley, B.G. Davis, M.L.H. Green, Removal of amorphous carbon for the efficient sidewall functionalisation of single-walled carbon nanotubes, Chem. Commun. (2007) 5090-5092.
[52] M.N. Tchoul, W.T. Ford, G. Lolli, D.E. Resasco, S. Arepalli, Effect of mild nitric acid oxidation on dispersability, size, and structure of single-walled carbon nanotubes, Chem. Mater. 19 (2007) 5765-5772.

[53] L.R. Gu, P.J.G. Luo, H.F. Wang, M.J. Meziani, Y. Lin, L.M. Veca, L. Cao, F.S. Lu, X. Wang, R.A. Quinn, W. Wang, P.Y. Zhang, S. Lacher, Y.P. Sun, Single-walled carbon nanotube as a unique scaffold for the multivalent display of sugars, Biomacromolecules 9 (2008) 2408-2418.

[54] Y.T. Shieh, G.L. Liu, H.H. Wu, C.C. Lee, Effects of polarity and pH on the solubility of acid-treated carbon nanotubes in different media, Carbon 45 (2007) 1880-1890.

[55] Y.T. Shieh, J.Y. Chen, Y.K. Twu, W.J. Chen, The effect of $\mathrm{pH}$ and ionic strength on the dispersion of carbon nanotubes in poly(acrylic acid) solutions, Polym. Int. 61 (2012) 554-559.

[56] E. Heister, C. Lamprecht, V. Neves, C. Tilmaciu, L. Datas, E. Flahaut, B. Soula, P. Hinterdorfer, H.M. Coley, S.R.P. Silva, J. McFadden, Higher dispersion efficacy of functionalized carbon nanotubes in chemical and biological environments, ACS Nano 4 (2010) 2615-2626.

[57] C. Bussy, J. Cambedouzou, S. Lanone, E. Leccia, V. Heresanu, M. Pinault, M. Mayne-I'Hermite, N. Brun, C. Mory, M. Cotte, J. Doucet, J. Boczkowski, P. Launoist, Carbon nanotubes in macrophages: imaging and chemical analysis by X-ray fluorescence microscopy, Nano Lett. 8 (2008) 2659-2663.

[58] L.M. Sargent, A.A. Shvedova, A.F. Hubbs, J.L. Salisbury, S.A. Benkovic, M.L. Kashon, D.T. Lowry, A.R. Murray, E.R. Kisin, S. Friend, K.T. McKinstry, L. Battelli, S.H. Reynolds, Induction of aneuploidy by single-walled carbon nanotubes, Environ. Mol. Mutagen 50 (2009) 708-717.

[59] A.D. Maynard, P.A. Baron, M. Foley, A.A. Shvedova, E.R. Kisin, V. Castranova Exposure to carbon nanotube material: aerosol release during the handling of unrefined single-walled carbon nanotube material, J. Toxicol. Environ. Health Part A 67 (2004) 87-107.

[60] H. Jin, D.A. Heller, R. Sharma, M.S. Strano, Size-dependent cellular uptake and expulsion of single-walled carbon nanotubes: single particle tracking and a generic uptake model for nanoparticles, ACS Nano 3 (2009) 149-158.

[61] S. Pogodin, V.A. Baulin, Can a carbon nanotube pierce through a phospholipid bilayer? ACS Nano 4 (2010) 5293-5300.

[62] S. Chakraborty, J. Chattopadhyay, H. Peng, Z. Chen, A. Mukherjee, R.S. Arvidson, R.H. Hauge, W.E. Billups, Surface area measurement of functionalized singlewalled carbon nanotubes, J. Phys. Chem. B 110 (2006) 24812-24815.

[63] P. Asuri, S.S. Karajanagi, A.A. Vertegel, J.S. Dordick, R.S. Kane, Enhanced stability of enzymes adsorbed onto nanoparticles, J. Nanosci. Nanotechnol. 7 (2007) 1675-1678.

[64] P. Asuri, S.S. Karajanagi, H. Yang, T.J. Yim, R.S. Kane, J.S. Dordick, Increasing protein stability through control of the nanoscale environment, Langmuir 22 (2006) 5833-5836.

[65] S.S. Karajanagi, H. Yang, P. Asuri, E. Sellitto, J.S. Dordick, R.S. Kane, Proteinassisted solubilization of single-walled carbon nanotubes, Langmuir 22 (2006) 1392-1395.

[66] M.A. Alonso-Lomillo, O. Ruediger, A. Maroto-Valiente, M. Velez, I. Rodriguez-Ramos, F.J. Munoz, V.M. Fernandez, A.L. De Lacey, Hydrogenasecoated carbon nanotubes for efficient $\mathrm{H}_{2}$ oxidation, Nano Lett. 7 (2007) 1603-1608.

[67] X. Yu, D. Chattopadhyay, I. Galeska, F. Papadimitrakopoulos, J.F. Rusling, Peroxidase activity of enzymes bound to the ends of single-wall carbon nanotube forest electrodes, Electrochem. Commun. 5 (2003) 408-411.

[68] P. Asuri, S.S. Bale, S.S. Karajanagi, R.S. Kane, The protein-nanomaterial interface, Curr. Opin. Biotechnol. 17 (2006) 562-568.

[69] P. Asuri, S.S. Karajanagi, E. Sellitto, D.Y. Kim, R.S. Kane, J.S. Dordick Water-soluble carbon nanotube-enzyme conjugates as functional biocatalytic formulations, Biotechnol. Bioeng. 95 (2006) 804-811

[70] P. Asuri, S.S. Karajanagi, J.S. Dordick, R.S. Kane, Directed assembly of carbon nanotubes at liquid-liquid interfaces: nanoscale conveyors for interfacial biocatalysis, J. Am. Chem. Soc. 128 (2006) 1046-1047.

[71] K.A. Joshi, J. Tang, R. Haddon, J. Wang, W. Chen, A. Mulchandani, A disposable biosensor for organophosphorus nerve agents based on carbon nanotubes modified thick film strip electrode, Electroanalysis 17 (2005) 54-58.

[72] J. Li, Y.-B. Wang, J.-D. Qiu, D.-C. Sun, X.-H. Xia, Biocomposites of covalently linked glucose oxidase on carbon nanotubes for glucose biosensor, Anal. Bioanal. Chem. 383 (2005) 918-922.

[73] N. Jia, L. Liu, Q. Zhou, L. Wang, M. Yan, Z. Jiang, Bioelectrochemistry and enzymatic activity of glucose oxidase immobilized onto the bamboo-shaped $\mathrm{CN} x$ nanotubes, Electrochim. Acta 51 (2005) 611-618.

[74] W.C.Zhang, X.H. Dai, Y.Zhao, X.M. Lu, P.J. Gao, Comparison of the different types of surfactants for the effect on activity and structure of soybean peroxidase, Langmuir 25 (2009) 2363-2368.

[75] Y. Lin, S. Taylor, H. Li, K.A.S. Fernando, L. Qu, W. Wang, L. Gu, B. Zhou, Y.-P. Sun, Advances toward bioapplications of carbon nanotubes, J. Mater. Chem. 14 (2004) 527-541.

[76] Y.P. Sun, K. Fu, Y. Lin, W. Huang, Functionalized carbon nanotubes: properties and applications, Acc. Chem. Res. 35 (2002) 1096-1104.

[77] R.H. Baughman, A.A. Zakhidov, W.A. de Heer, Carbon nanotubes-the route toward applications, Science 297 (2002) 787-792. 


\title{
Perhydrolase-nanotube-paint sporicidal composites stabilized by intramolecular crosslinking
}

\author{
Cerasela Zoica Dinu ${ }^{\mathrm{a}, *, 1}$, Indrakant V. Borkar ${ }^{\mathrm{b}, \mathrm{c}, 1}$, Shyam Sundhar Bale ${ }^{\mathrm{b}, \mathrm{c}}$, Alan S. Campbell $^{\mathrm{a}}$, \\ Ravi S. Kane ${ }^{\mathrm{b}, \mathrm{c}}$, Jonathan S. Dordick ${ }^{\mathrm{b}, \mathrm{c}, * *}$ \\ a Department of Chemical Engineering, College of Engineering and Mineral Resources, West Virginia University, Morgantown, WV 26506, USA \\ ${ }^{b}$ Department of Chemical and Biological Engineering, Rensselaer Nanotechnology Center, Rensselaer Polytechnic Institute, Troy, NY 12180, USA \\ ' Center for Biotechnology E' Interdisciplinary Studies, Rensselaer Polytechnic Institute, Troy, NY 12180, USA
}

\section{A R T I C L E I N F O}

\section{Article history:}

Received 19 June 2011

Received in revised form 12 October 2011

Accepted 1 November 2011

Available online 10 November 2011

\section{Keywords:}

Carbon nanotubes

AcT

Crosslinking

Stability

Decontamination

\begin{abstract}
A B S T R A C T
We have developed a strategy to preserve the activity and operational stability of a large multi-subunit enzyme immobilized onto carbon nanotubes and incorporated into latex paint. Our strategy involved the intramolecular crosslinking of perhydrolase S54V (AcT, a homo-octamer) and the subsequent immobilization of the crosslinked AcT onto single-walled carbon nanotubes (SWNTs). We employed aldehyde dextran - a bulky polymeric aldehyde obtained by oxidation of dextran with sodium metaperiodate as a crosslinking reagent. The activity of AcT crosslinked with aldehyde dextran and covalently attached to SWNTs (AcT-dex-SWNTs) was $~ 40 \%$ of that of native AcT and more than two-fold higher than that of enzyme immobilized directly, i.e., without crosslinking. This relatively high retention of AcT activity was consistent with the nearly complete retention of the enzyme's secondary structure upon attachment to the nanoscale support. Further incorporation of the AcT-dex-SWNTs conjugates into a latex-based paint led to active composites that were used to decontaminate Bacillus spores.
\end{abstract}

(ㄷ) 2011 Elsevier B.V. All rights reserved.

\section{Introduction}

AcT, isolated from Mycobacterium smegmatis, is a homo-octamer of $184 \mathrm{kDa}$ with $72 \times 72 \times 60 \AA$ dimensions [1] that effectively catalyzes the perhydrolysis of propylene glycol diacetate (PGD) to generate peracetic acid (PAA) (Scheme 1 ), a potent decontaminant effective against bacteria, yeasts, fungi, and spores [2-4]. AcT has a perhydrolysis to hydrolysis ratio greater than 1 and an activity 50fold higher than that of the best lipase tested [5,6]. This makes AcT a potentially valuable biocatalyst for decontaminating various surfaces if highly active and stable enzyme-based surface formulations could be developed. Nonetheless, identifying methods to improve enzyme activity and stability, particularly upon extended exposure

\footnotetext{
* Corresponding author at: Department of Chemical Engineering, West Virginia University, College of Engineering and Mineral Resources, PO Box 6102, ESB 445, Morgantown, WV 26506, USA. Tel.: +1 304293 9338; fax: +1 3042934139.

** Corresponding author at: Department of Chemical and Biological Engineering, Department of Biology, 2213 Center for Biotechnology Interdisciplinary Studies, Rensselaer Polytechnic Institute, 110 8th Street, Troy, NY 12180, USA. Tel.: +1 518276 2899; fax: +1 5182762207 .

E-mail addresses: cerasela-zoica.dinu@mail.wvu.edu (C.Z. Dinu), dordick@rpi.edu (J.S. Dordick).

1 These authors contributed equally to this work.
}

to the PAA product remains a formidable challenge. Moreover, the large size of AcT coupled to its relatively high degree of surface hydrophobicity may also limit its long-term use [1,6].

We have focused on stabilizing enzymes by attachment, both covalently and non-covalently, onto carbon nanotubes. Indeed, in the case of AcT, we have begun to test the biological decontamination of Bacillus cereus, a simulant of Bacillus anthracis, by AcT immobilized onto multi-walled carbon nanotube (MWNTs) and incorporated into polymeric films and paint composites [1]. Carbon nanotubes have excellent support characteristics due to their high surface area to volume ratios that allow relatively high enzyme loadings [7-11], ease of recovery by filtration for the enzymenanotube conjugate [1], and high aspect ratios that results in entrapment of the support in coatings, films and paints, thereby preventing leaching of any attached biocatalyst from the surface [1]. Critically, we hypothesize that the operational and thermal stability of a large multi-subunit enzyme such as AcT may be increased on a surface if greater rigidity of the enzyme were induced, for example, via crosslinking prior to attachment onto the nanoscale support. Along these lines, homo-bi- or poly-functional aldehydes, such as glutaraldehyde or aldehyde dextran, respectively, have been used to crosslink multimeric enzymes [12], thus increasing the rigidity of the enzyme and avoiding the formation of non-specific protein-protein associations. 


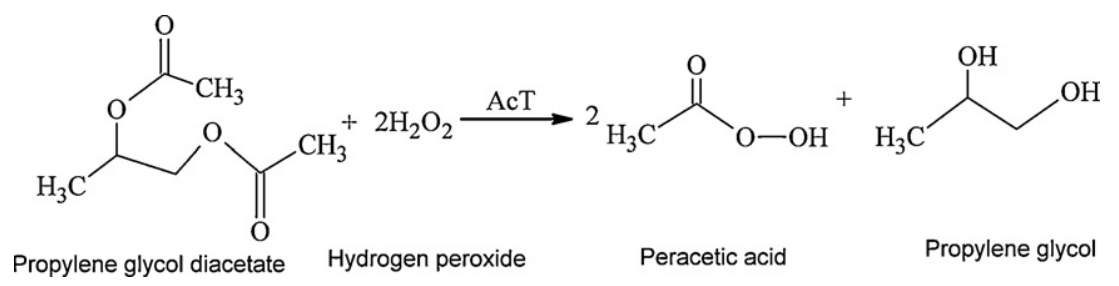

Scheme 1.

In the current work we sought to improve AcT activity and stability when attached to single-walled carbon nanotubes (SWNTs). SWNTs were chosen as supports, as their higher surface curvature when compared with MWNTs, is expected to reduce lateral interactions between adjacent protein molecules adsorbed, leading to greater retention of native protein structure and activity. Specifically, we show that by crosslinking AcT with the polyfunctional aldehyde dextran followed by covalent attachment onto SWNTs, we can dramatically improve enzyme operational stability, thermostability, and activity of the resulting conjugates. Further incorporation of the conjugates into paint led to composites that showed complete decontamination of $10^{6}$ Colony Forming Units $(\mathrm{CFU}) / \mathrm{mL}$ of $B$. cereus spores in $60 \mathrm{~min}$.

\section{Results and discussion}

Biological decontamination is aimed at eliminating biological hazards associated with pathogens infecting solid surfaces in laboratories [13], pilot plants [14,15], hospitals [16] or battlefield settings [17]. Decontamination involves rapid removal or neutralization of the pathogen using physical and/or chemical methods. An ideal decontaminant must be non-corrosive, non-toxic, and environmentally friendly. Enzymatic decontamination methods possess such ideal properties, since they are biodegradable, safe, easy to use, environmentally benign, and effective in low-volume doses $[1,17,18]$. AcT-catalyzed synthesis of PAA (Scheme 1) represents an excellent example of one such biologically driven decontamination, and thus, serves as a practical model system in this study.

Following our previous methodology [1], AcT was initially covalently attached to acid-oxidized SWNTs, which possessed carboxylic acid "handles" ideal for EDC/NHS coupling chemistry (Scheme 2a). The hydrophilic carboxyl moieties also increased nanotube dispersion and solubility [1]. Covalent attachment of AcT onto SWNTs led to enzyme loadings of $0.15 \pm 0.01 \mathrm{mg}$ AcT per mg SWNTs. However, AcT-SWNT conjugates retained $<20 \%$ of the native solution specific activity of AcT (Fig. 1a). In contrast, when MWNTs were used as supports for AcT covalent attachment, only $8 \%$ specific activity was retained at a similar loading as that for SWNTs (see Supporting materials). This is in agreement with previous reports that show that enzyme structure and function when bound to SWNTs or silica nanoparticles are more native-like than when bound to flatter surfaces $[1,19]$. The hydrophobic nature of AcT (aliphatic index of 95.66, grand average hydropathicity (GRAVY) of 0.117 based on computational analysis [1]), may also lead to non-specific (and potentially unfavorable) hydrophobic interactions between the enzyme and non-functionalized hydrophobic regions of the SWNTs and MWNTs. Such interactions could be strong enough to alter enzyme structure and reduce catalytic activity. Encouraged by the higher activity retained by AcT immobilized on the SWNTs, we proceeded to use these supports in this work.

Chemical modification of proteins with crosslinkers is known to reduce non-specific interactions [12,20-22]; however, to our knowledge no work has been performed on crosslinking enzymes followed by attachment onto nanoscale supports. To that end, we

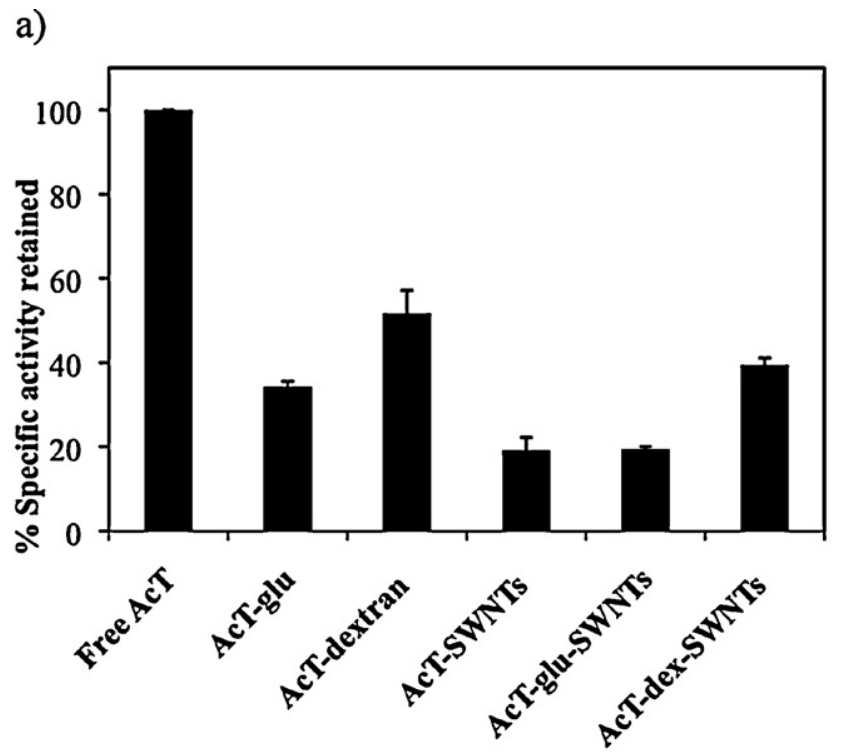

b)

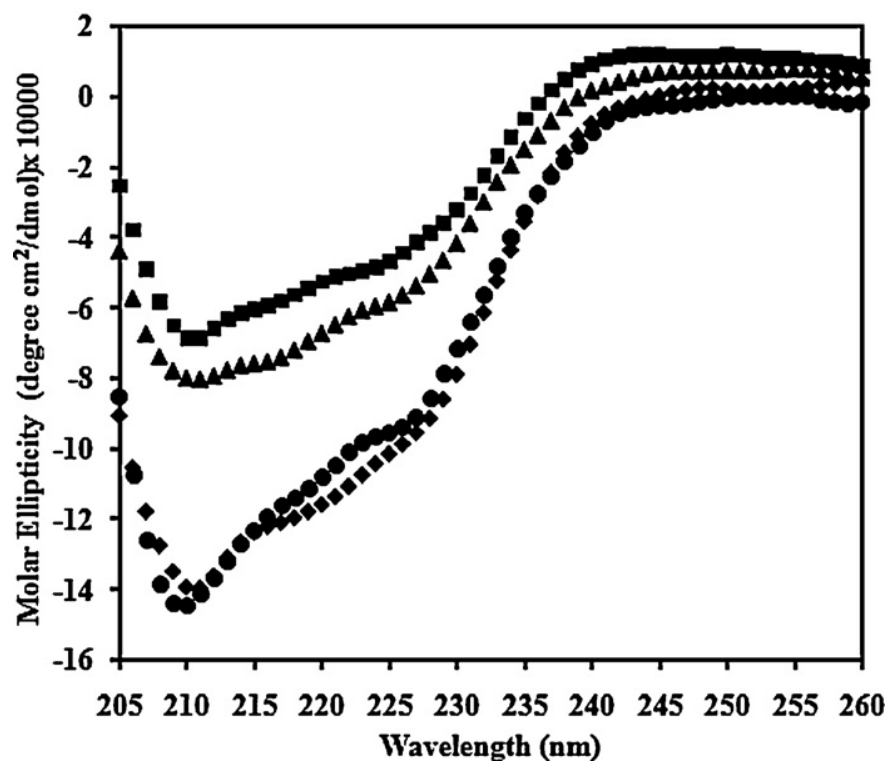

Fig. 1. (a) Specific activity of crosslinked AcT and AcT-nanotube conjugates when compared to free AcT. (b) Far-UV CD spectra of native AcT (filled diamond), AcT crosslinked with aldehyde dextran (filled circle), AcT crosslinked with $0.5 \%$ glutaraldehyde (filled square) and AcT crosslinked with $0.25 \%$ glutaraldehyde (filled triangle). At least 5 replicates were performed.

performed light crosslinking of AcT with 0.25 and $0.50 \%(w / w)$ glutaraldehyde. In both cases, the relatively light crosslinking did not result in inter-enzyme molecular linkages, as SDS-PAGE gels showed a band at roughly the same molecular weight as free AcT (Scheme 2b). No higher molecular weight bands were observed. The activity of the crosslinked AcT (AcT-glu) was $34 \%$ of the free 
a) Preparation of AcT-based conjugates and composites

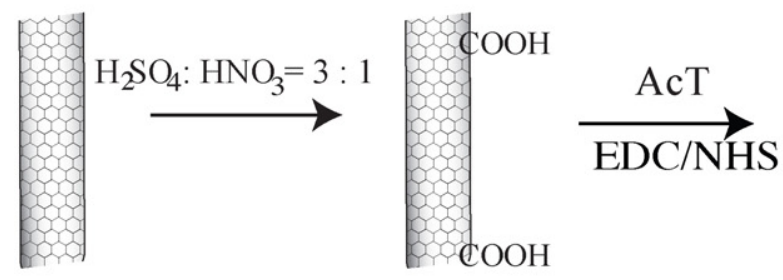

SWNT Acid functionalized SWNT

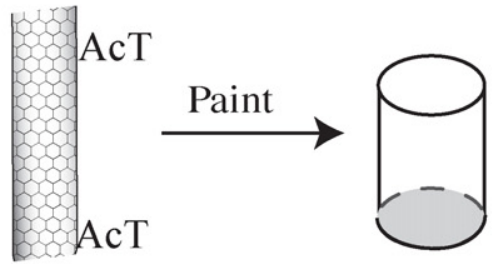

AcT-nanotube based conjugate
AcT-nanotube based composite

b) Preparation of crosslinked AcT

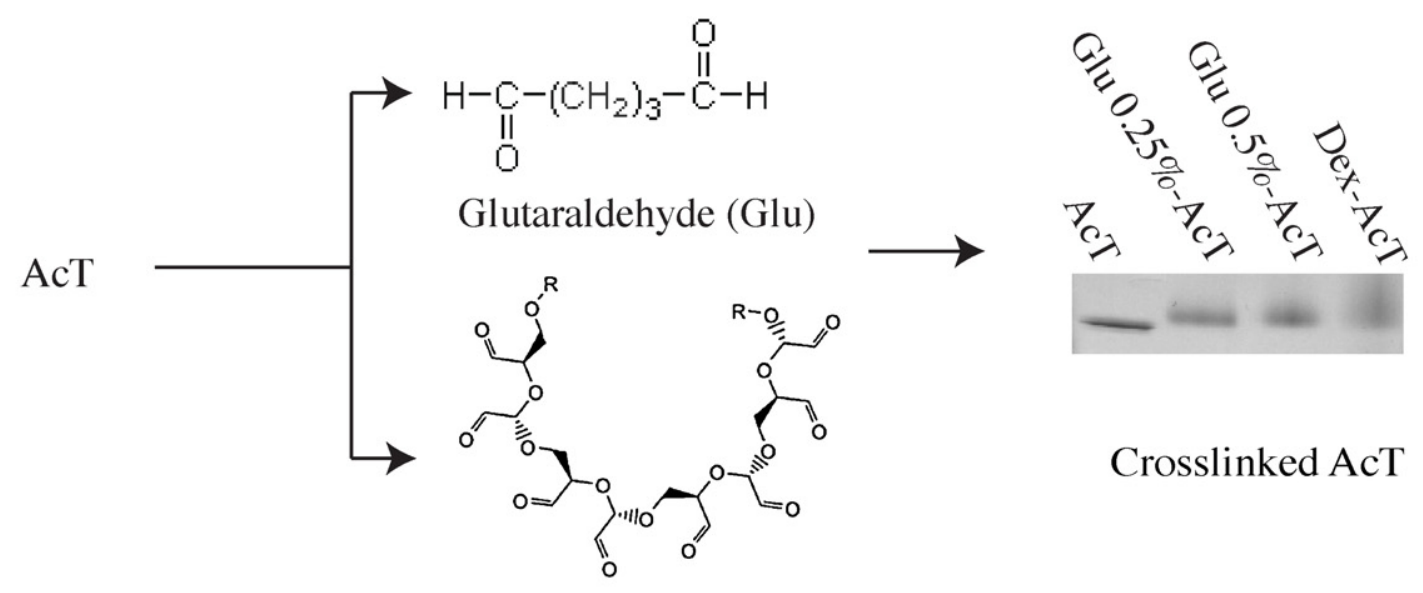

Aldehyde dextran (Dex)

\section{c) Decontamination of Biological Agent by Nano-based Composites}

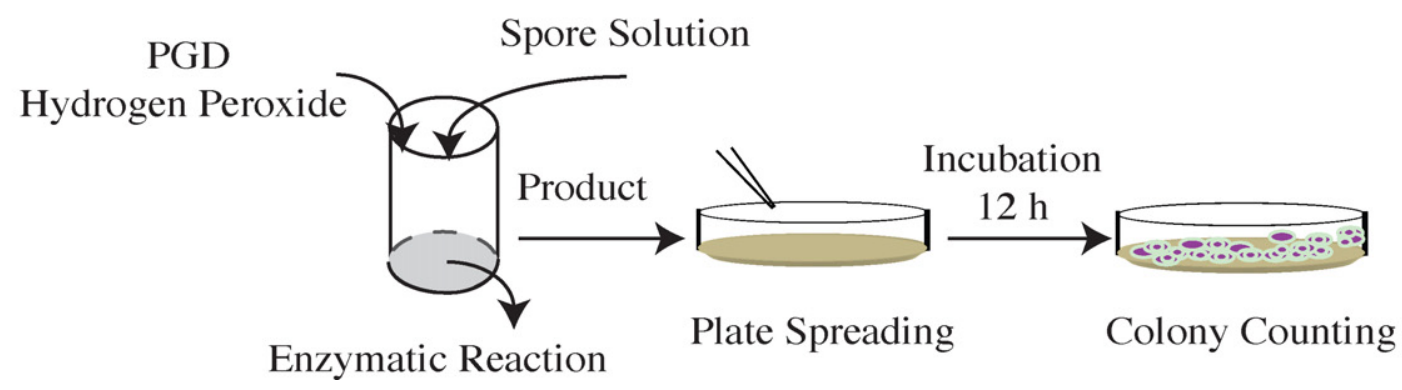

Scheme 2.

enzyme activity (Fig. 1a). We rationalized that the loss in activity may have been due to reaction of glutaraldehyde with key amino acid residues near the active site of the enzyme and/or because the small size of glutaraldehyde blocks the active site channel of AcT $[12,22]$. To overcome either of these deleterious outcomes, we performed light crosslinking with the polymeric aldehyde dextran prepared by oxidizing dextran $(20 \mathrm{kDa})$ with sodium periodate. As with glutaraldehyde, light crosslinking with 0.25 and $0.50 \%$ $(\mathrm{w} / \mathrm{w})$ dextran aldehyde resulted in exclusively intramolecular AcT crosslinks (Scheme $2 b$ ). The somewhat diffuse band with increased molecular weight was due to the polydispersity of the dextran aldehyde. In no case did we observe molecular weights of $2 \times$ or $3 \times$ of native AcT, indicating that only intramolecular crosslinking had occurred. The activity of the crosslinked Act-dex was $\sim 52 \%$ of that of free AcT (Fig. 1a). The relatively high retention of catalytic activity of the AcT-dex would suggest that the enzyme's secondary structure remained intact. Indeed, comparison of the circular dichroism (CD) spectrum of AcT-dex to that of native AcT (Fig. 1b) revealed that the enzyme retained the majority of its secondary structure, specifically $\sim 93 \%$ of the native AcT $\alpha$-helix content. Act-glu, however, was 


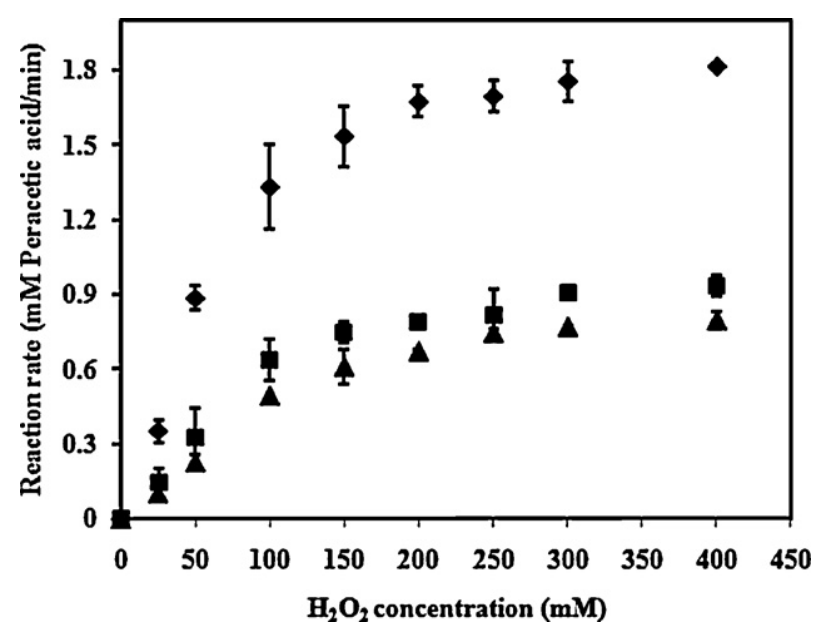

Fig. 2. Kinetics of parameters of free AcT (filled diamond), AcT crosslinked with aldehyde dextran (filled squares), and AcT crosslinked with aldehyde dextran and immobilized onto SWNTs (filled triangle). The concentration of hydrogen peroxide was varied from $0.1 \mathrm{mM}$ to $428 \mathrm{mM}$ while the concentration of PGD was kept constant at $200 \mathrm{mM}$. At least 5 replicates were performed.

Table 1

Kinetic parameters of free, crosslinked and immobilized AcT.

\begin{tabular}{llcl}
\hline & $V_{\mathrm{m}}{ }^{\mathrm{a}}(\mathrm{mM} / \mathrm{min})$ & $K_{\mathrm{m}}(\mathrm{mM})$ & $V_{\mathrm{m}} / K_{\mathrm{m}}\left(\mathrm{min}^{-1}\right)$ \\
\hline Free AcT & 2.08 & 55 & 0.038 \\
AcT-Dex & 1.12 & 88 & 0.0125 \\
AcT-Dex-SWNTs & 1.02 & 110 & 0.0095 \\
\hline
\end{tabular}

a The values represent an average of measurements with standard error $<7 \%$.

structurally perturbed (Fig. 1b) with only $67 \%$ secondary structure retention even at $0.25 \%$ glutaraldehyde. This result is consistent with greater loss of activity of AcT-glu vs. AcT-dex.

To assess whether the pre-immobilization crosslinking-induced AcT stabilization by aldehyde dextran could carry over to AcT-based conjugates, we used EDC/NHS coupling to attach both glutaraldehyde- (as a comparison) and aldehyde dextrancrosslinked AcT to SWNTs in a methodology similar to that shown in Scheme $2 \mathrm{a}$. AcT-glu-SWNT conjugates retained $\sim 19 \%$ of native AcT activity, while AcT-dex-SWNT conjugates retained $~ 40 \%$ of native AcT activity (Fig. 1a) and nearly $80 \%$ of the activity of the AcTdex pre-immobilized crosslinked enzyme form. In another strategy, attachment of crosslinked AcT to SWNTs was performed using an amphiphilic poly(ethylene glycol) (PEG) linker [1]. Theoretically, this type of linker could improve enzyme activity by reducing nonspecific binding between the enzyme and the nanosupport, as well as it can provide more favorable orientation of the protein at the nanoscale surface $[1,17]$. However, no improvement in enzyme activity was observed for AcT attached to the SWNTs via the PEG linker (see Supporting material). Thus, crosslinking with the polymeric aldehyde dextran stabilizes AcT against nanotube facilitated protein deactivation.

The kinetics of AcT-dex and AcT-dex-SWNT ( $2 \mu \mathrm{g}$ free or equivalent of immobilized enzyme) was studied by measuring the initial reaction rates at different substrate concentrations. The concentration of hydrogen peroxide was varied from $0.1 \mathrm{mM}$ to $428 \mathrm{mM}$ while the concentration of PGD was kept constant at $200 \mathrm{mM}$. AcT-dex and AcT-dex-SWNT both followed Michaelis-Menten kinetics as a function of $\mathrm{H}_{2} \mathrm{O}_{2}$ concentration (Fig. 2) with fairly $\operatorname{similar}\left(V_{\max } / K_{\mathrm{m}}\right)$ values (Table 1) and ca. 25-33\% of that of the native enzyme, as a result of roughly equal contributions of lower $V_{\max }$ and higher $K_{\mathrm{m}}$. Importantly, the relatively minor changes in both $V_{\max }$ and $K_{\mathrm{m}}$ indicate that the enzyme retained its intrinsic function following both crosslinking with aldehyde dextran and attachment to SWNTs.
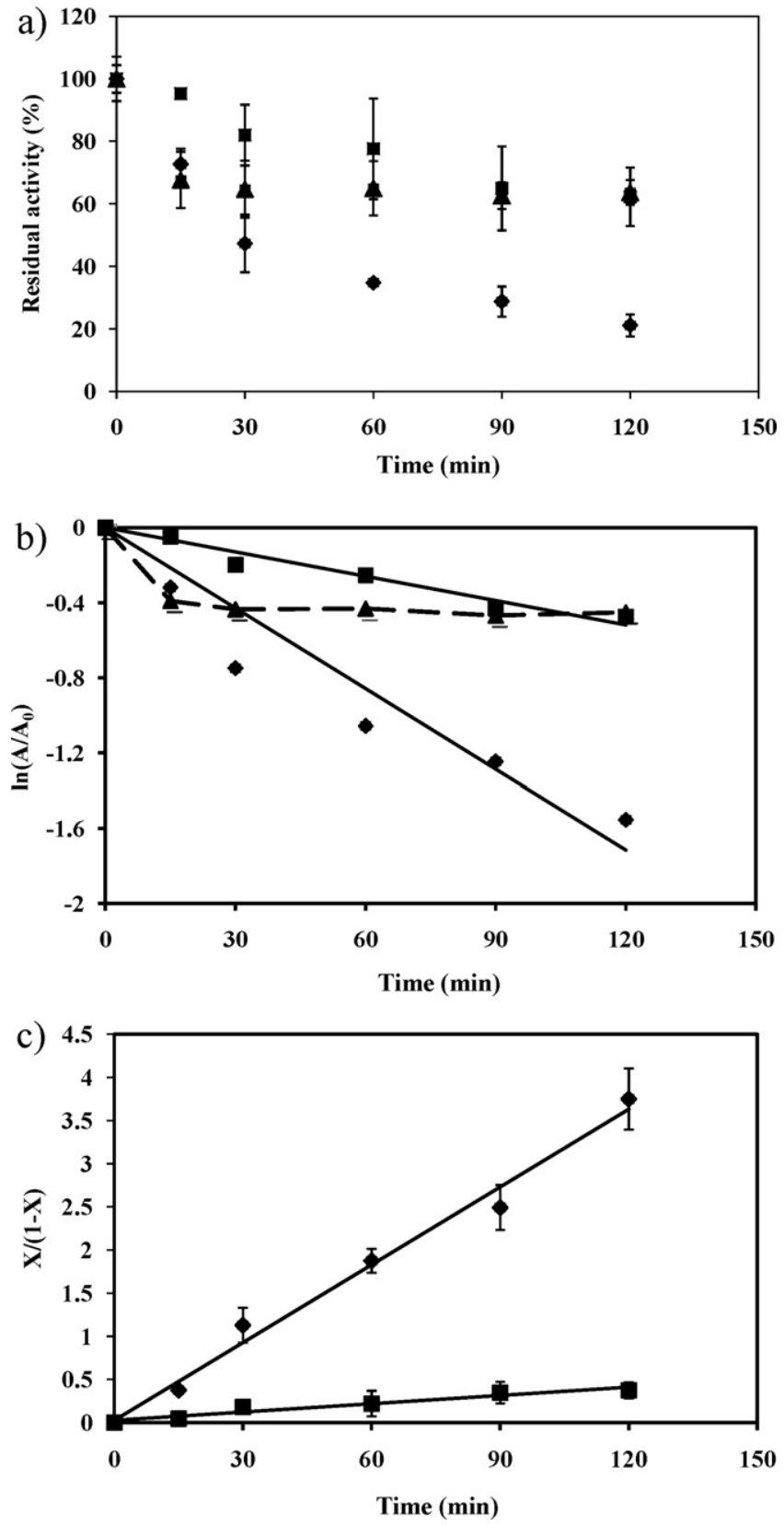

Fig. 3. (a) Thermal stability of free AcT (filled diamond), AcT crosslinked with aldehyde dextran (filled squares) and AcT crosslinked with aldehyde dextran and immobilized onto SWNTs (filled triangles) at $75^{\circ} \mathrm{C}$. (b) and (c) Deactivation plots following second order deactivation model. To confirm the data, at least 5 replicates were performed.

The combination of retained secondary structure and high activity as a result of AcT-dex crosslinking indicates that the polymeric aldehyde is restricted from gaining access to the active site and is likely causing rigidification of the multi-subunit enzyme thus leading to maintaining activity on the heterogeneous SWNT. Such rigidification would be expected to stabilize the enzyme under harsh conditions, for example, high temperature. To test this stabilization, we incubated AcT, AcT-dex, and AcT-dex-SWNTs at $75^{\circ} \mathrm{C}$ for up to $2 \mathrm{~h}$. While the free enzyme lost nearly $80 \%$ of its activity at $75^{\circ} \mathrm{C}$ after $2 \mathrm{~h}$, AcT-dex and AcT-dex-SWNTs retained more than $65 \%$ activity under these conditions (Fig. 3a). Moreover, free AcT and AcT-dex followed second order thermal deactivation (Fig. 3b and c). A typical second order thermal deactivation model is reflected 


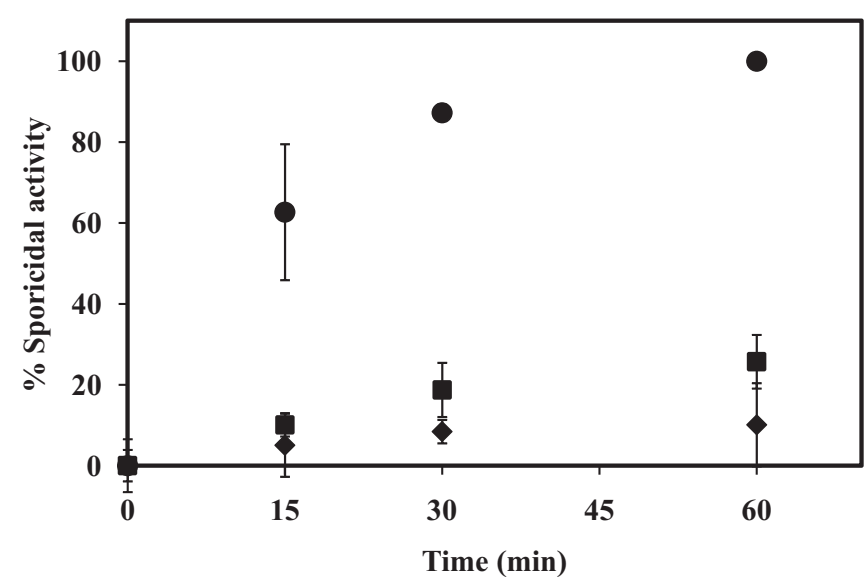

Fig. 4. Sporicidal activity of cross-linked AcT-nanotube based composites: control films (spores in buffer, filled diamond), films containing cross-linked AcT-nanotube (filled circles) and control spores in PGD and $\mathrm{H}_{2} \mathrm{O}_{2}$ reaction mixture (filled squares). At least 5 replicates were performed.

in Eq. (1), where A is the residual AcT activity and $k_{d}$ is the second order deactivation rate constant.

$\frac{d A}{d t}=-k_{d} A^{2}$

Integration of Eq. (1) within limits leads to Eq. (2) where $A_{0}$ is the initial activity of AcT and $X$ is the fraction of enzyme deactivated.

$\frac{X}{(1-X)}=A_{0} k_{d} t$

Plotting $X /(1-X)$ versus time confirmed second-order deactivation kinetics (Fig. 3c) and allowed determination of $A_{0} k_{d}$ values. Half-life times $\left(t_{1 / 2}\right)$ at $75^{\circ} \mathrm{C}$ were calculated using Eq. (3), which gave values of 33 and 313 min for free AcT and AcT-dex, respectively.

$t_{1 / 2}=\frac{1}{A_{0} k_{d}}$

These results are consistent with the primary deactivation of native AcT at elevated temperature being due to aggregation. AcT-dex-SWNTs do not appear to follow second order thermal deactivation (Fig. 3b), consistent with a restricted rotational degree of freedom resulting from its multi-point attachment to the nanoscale support. Further stabilization from aggregation may be due to decreased protein-protein interactions on the highly curved surface of the SWNTs [23]. In addition to thermal stability, we also studied the operational stability of AcT-dex-SWNT incubated at $4{ }^{\circ} \mathrm{C}$ for up to 180 days. No loss of activity was observed under these typical storage conditions, further confirming the high stability afforded by crosslinking of the enzyme with aldehyde dextran and attachment to the SWNT.

Motivated by the increased stability of the crosslinked enzyme bound to SWNTs, we proceeded to incorporate the crosslinkedconjugates into a latex paint (Scheme 2c) to form nanocomposites that can decontaminate $B$. cereus spores [24-29]. The high aspect ratio of the SWNTs allowed retention of the enzyme within the composite with no enzyme leaching being observed after 15 days incubation in buffer [17]. As a control, when free AcT or AcT-dex was directly added to the latex solution and dried (i.e., no nanotubes), nearly $50 \%$ of the enzyme leached out from that paint within the first $30 \mathrm{~min}$. When challenged with $10^{6} \mathrm{CFU} / \mathrm{mL}$, AcT-dex-SWNT paints (containing $0.04 \%, \mathrm{w} / \mathrm{w}, \mathrm{AcT}$ ) incubated in a solution containing $100 \mathrm{mM}$ each of PGD and $\mathrm{H}_{2} \mathrm{O}_{2}$ generated ca. $10 \mathrm{mM}$ PAA and killed $>99 \%$ of the spores within $1 \mathrm{~h}$ (Fig. 4). Specifically, in only 15 min we achieved approximately $60 \%$ spore killing, which is in agreement with previous literature reports for direct PAA addition
[30-32]. Moreover, when the composites were challenged with $10^{6} \mathrm{CFU} / \mathrm{mL}$ of a simple non-spore forming bacterium, E. coli, the killing time was reduced to $5 \mathrm{~min}$.

\section{Conclusions}

We have shown that the use of aldehyde dextran as a crosslinking agent stabilizes the native structure of AcT. The enzyme retains high activity ( $>40 \%$ of native aqueous solution activity) and can be incorporated into paint-based composites that have decontamination properties against $B$. cereus (a simulant of $B$. anthracis) and $E$. coli. Further work is underway to assess composite stability and activity in a wide variety of conditions (i.e., temperature, humidity, various paint compositions and polymers, etc.). The capability of generating sufficiently high concentrations of PAA makes these composites particularly useful as surface coatings for the disinfection of a wide range of pathogenic agents including bacteria and spores.

\section{Experimental}

\subsection{AcT crosslinking with glutaraldehyde}

Perhydrolase S54 (AcT, $1 \mathrm{mg} / \mathrm{mL}$, gift from Genencor International, Inc. Palo Alto, CA, USA) was incubated at $4{ }^{\circ} \mathrm{C}$ with 0.25 and $0.50 \%$ of glutaraldehyde (Sigma, USA), respectively, for $24 \mathrm{~h}$. Thus crosslinked AcT was treated with $10 \%(\mathrm{v} / \mathrm{v})$ Tris- $\mathrm{HCl}$ buffer $(1 \mathrm{M}$, $\mathrm{pH} 8$, Sigma, USA). Excess reactants were removed by extensive dialysis against water at $4{ }^{\circ} \mathrm{C}$ for $24 \mathrm{~h}[33,34]$.

\subsection{AcT crosslinking with aldehyde dextran}

Aldehyde dextran was obtained by fully oxidizing $50 \mathrm{~mL}$ of dextran ( $20 \mathrm{kDa}, 33.3 \mathrm{mg} / \mathrm{mL}$, Sigma, USA) with sodium periodate (4.36 g, Sigma, USA) in distilled water $(21,37)$. After $2 \mathrm{~h}$ incubation in dark, the oxidized dextran was extensively dialyzed against distilled water at $4{ }^{\circ} \mathrm{C}$ for $24 \mathrm{~h}$. The purified aldehyde dextran was then lyophilized for long-term storage. AcT $(5 \mathrm{~mL})$ in $50 \mathrm{mM}$ sodium phosphate buffer ( $100 \mathrm{mM}, \mathrm{pH}$ 7) was added to $150 \mathrm{mg}$ of aldehyde dextran (final AcT concentration was $1 \mathrm{mg} / \mathrm{mL}$ ) in the presence of $150 \mathrm{mM}$ trimethylaminoborane (Sigma, USA) for $24 \mathrm{~h}$ at $25^{\circ} \mathrm{C}$. Schiff bases, formed between the primary amino groups of the enzyme and the aldehyde groups of the polymer were reduced by the addition of $3 \mathrm{mg} / \mathrm{mL}$ sodium borohydride (Sigma, USA) at $\mathrm{pH}$ 10 [12]. After $30 \mathrm{~min}$, the $\mathrm{pH}$ was decreased to 7 by the addition of $\mathrm{HCl}$. Aldehyde dextran was further treated with $10 \%$ Tris- $\mathrm{HCl}$ (1 M, $\mathrm{pH} 8$ ) in order to avoid non-specific crosslinking.

\subsection{Crosslinking of the AcT confirmed by gel electrophoresis}

Gel electrophoresis was used to confirm enzyme crosslinking. Specifically, NuPAGE ${ }^{\circledR}$ Novex $^{\circledR}$ Tris-Acetate Gels (Native-PAGE) (Invitrogen, USA) of 4-12\% gradient, 10-well was loaded with $25 \mu \mathrm{l}$ sample of $0.01 \mathrm{mg} / \mathrm{ml} \mathrm{AcT}$ or equivalent of AcT-derivates (i.e., AcTdex, AcT-glu, etc.) prepared in Novex ${ }^{\circledR}$ Tris-Glycine Native Sample Buffer (Invitrogen, USA). Appropriate unstained molecular weight marker NativeMark ${ }^{\mathrm{TM}}$ (Invitrogen, USA) was also used. The gel run at $80 \mathrm{~V}$ for $120 \mathrm{~min}$ in Novex ${ }^{\circledR}$ Tris-Glycine Native Running Buffer and was stained with polyacrylamide pre-cast gel SimplyBlue ${ }^{\mathrm{TM}}$ Coomassie protein stain (Invitrogen, USA), $1 \times$ pre-mixed solution.

\subsection{Acid oxidation of carbon nanotubes}

SWNTs were purchased from Unidym, Inc. (USA) and oxidized as previously described (1). Briefly, $100 \mathrm{mg}$ SWNTs were suspended 
in $60 \mathrm{~mL}$ of $3: 1(\mathrm{v} / \mathrm{v})$ sulfuric acid to nitric acid $\left(\mathrm{H}_{2} \mathrm{SO}_{4}: \mathrm{HNO}_{3}\right) \mathrm{mix}$ ture (Fisher Scientific, USA) and sonicated at room temperature for $6 \mathrm{~h}$. The acid oxidized SWNT suspension was diluted in distilled water and the mixture was filtered through $0.2 \mu \mathrm{m}$ polycarbonate filter membrane (Millipore, USA). The SWNT "cake" that formed on the filter was resuspended in distilled water by sonication and the filtration step was repeated until water-soluble SWNTs were obtained and any insoluble impurities were removed. The SWNTs were dried under vacuum and stored at room temperature.

\subsection{Functionalization of acid oxidized SWNTs with AcT and crosslinked AcT}

Free and crosslinked AcT was covalently attached to $6 \mathrm{~h}$ oxidized SWNTs using 1-ethyl-3-[3-dimethylaminopropyl] carbodiimide hydrochloride (EDC; Acros Organics, USA) and Nhydroxysuccinimide (NHS, Pierce, USA), respectively (1). Briefly, $2 \mathrm{mg}$ (SWNTs, $6 \mathrm{~h}$ oxidized nanotubes) were dispersed in $160 \mathrm{mM}$ EDC and $80 \mathrm{mM}$ NHS (total volume of $2 \mathrm{~mL}$ in MES (2-(Nmorpholino)ethanesulfonic acid sodium salt, $50 \mathrm{mM}, \mathrm{pH} 4.7$, Sigma) for $15 \mathrm{~min}$ at room temperature and $200 \mathrm{rpm}$. The activated SWNTs were next filtered through the $0.2 \mu \mathrm{m}$ filter, washed thoroughly with MES buffer to remove any ester residues, and immediately dispersed in $1 \mathrm{mg} / \mathrm{mL}$ AcT (free, crosslinked with glutaraldehyde, or crosslinked with aldehyde dextran respectively) solution in phosphate buffer ( $50 \mathrm{mM}, \mathrm{pH} 7.0)$ and incubated for $3 \mathrm{~h}$ at room temperature with shaking at $200 \mathrm{rpm}$. The resulting AcTbased-SWNT conjugates were filtered and washed extensively with buffer to remove any unbound enzymes (1) while the supernatants and washes were collected to quantify enzyme loading.

\subsection{Enzyme loading}

The amount of AcT attached to SWNTs (i.e., AcT loading) was determined using standard BCA assay (bicinchoninic acid, Pierce, USA) and subtracting the amount of enzyme washed out in the filtrates from the amount of AcT initially added to the SWNTs. Briefly, the working reagent was prepared by mixing 50 parts of reagent A (BCA Protein Assay Reagent A Formulation: Bicinchonic acid and tartrate in an alkaline carbonate buffer, http://www. piercenet.com/browse.cfm?fldID=02020101) with 1 part of reagent B (BCA Protein Assay Reagent B Formulation: 4\% copper sulfate pentahydrate solution, http://www.piercenet.com/browse.cfm?fldID= 02020101); subsequently $200 \mu$ l of the working reagent was incubated with $25 \mu \mathrm{L}$ AcT-based solution. The resulting solution was incubated in 96-well plate with a clear flat bottom (Thermo Scientific, USA) at $37^{\circ} \mathrm{C}$ for $30 \mathrm{~min}$. Absorbance at $562 \mathrm{~nm}$ was determined on a Microplate reader (SpectraMax M5, Molecular Devices, Sunnyvale, CA, USA). Control calibration curves were prepared using serial dilutions of AcT (free in solution) into the working reagent.

\subsection{Activity assay}

AcT activity was determined by measuring the peracetic acid (PAA) generated by the free or immobilized enzyme (1). In a typical reaction, $10.6 \mu \mathrm{L}$ hydrogen peroxide $\left(\mathrm{H}_{2} \mathrm{O}_{2}, 30 \%, \mathrm{v} / \mathrm{v}\right.$, from Sigma, USA) stock solution was added to a mixture of $0.8 \mathrm{~mL}$ propylene glycol diacetate (PGD, final concentration $100 \mathrm{mM}$ in potassium phosphate buffer, $50 \mathrm{mM}$, pH 7.1, Sigma, USA) and $0.2 \mathrm{~mL}$ AcT solution $(2 \mu \mathrm{g} / \mathrm{ml}$ final concentration for free AcT or equivalent concentration for AcT for AcT-based conjugates). The mixture was shaken at room temperature and $200 \mathrm{rpm}$ for $20 \mathrm{~min}$. The PAA assay was conducted by diluting $25 \mu \mathrm{L}$ of reaction solution 100 -fold in deionized water and subsequently mixing $25 \mu \mathrm{L}$ of the diluted solution with $75 \mu \mathrm{L}$ deionized water and $0.9 \mathrm{~mL}$ assay reagent (the assay reagent was prepared by mixing $5 \mathrm{~mL}$ potassium citrate buffer, $125 \mathrm{mM}$, pH 5.0 with $50 \mu \mathrm{L}$ ABTS water solution, $100 \mathrm{mM}$, and $10 \mu \mathrm{L}$ KI water solution, $25 \mathrm{mM}$; all the reagents were purchased from Sigma, USA). The mixture was then incubated at room temperature for $3 \mathrm{~min}$ and the absorbance at $420 \mathrm{~nm}$ was measured on a UV-vis spectrophotometer. PAA concentration was calculated as [PAA] $(\mathrm{mM})=A_{420 \mathrm{~nm}} \times 0.242 \times 400$ (400 is the dilution factor). The specific activity of AcT-based conjugates was calculated as the ratio of the normalized activity of the conjugates to that of the native AcT.

\subsection{Circular dichroism of AcT, crosslinked AcT and AcT-based conjugates}

Circular dichroism (CD) analysis was performed using a Jasco 815 Circular dichroism Spectrometer (Jasco Analytical Instruments, Inc., Easton, MD, USA). Free AcT, crosslinked AcT, and AcT-based conjugate samples were diluted in phosphate buffer to a final concentration of ca. $10 \mu \mathrm{g} / \mathrm{mL}$ AcT. The CD data were collected in the range of $205-260 \mathrm{~nm}$ and the molar ellipticity, $\theta$, was calculated using equation (4) where molecular weight of AcT is $184 \mathrm{kDa}$, the number of amino acids is 216 (PDB-2Q0S) and the cuvette path length is $1 \mathrm{~cm}$.

$$
[\theta]=\frac{\theta \times(\text { Molecular weight }(\mathrm{kDa}) / \text { No. amino acids })}{10 \times \text { path length }(\mathrm{cm}) \times[\mathrm{conc}](\mathrm{mg} / \mathrm{mL})}
$$

Subsequently, the residual structure of the protein in each of the cases was calculated using Eq. (5) (38).

$\% \alpha$-helix $=\frac{-[\theta]_{222} \mathrm{~nm}+3000}{39,000}$

\subsection{Kinetics of AcT, crosslinked AcT and AcT-based conjugates}

Kinetics of free AcT, crosslinked AcT and AcT-nanotube conjugates was studied by measuring the initial reaction rates of the samples at different substrate concentrations. Specifically, the concentration of $\mathrm{H}_{2} \mathrm{O}_{2}$ was varied from $0.1 \mathrm{mM}$ to $428 \mathrm{mM}$ while the PGD concentration was maintained at $200 \mathrm{mM}$.

\subsection{Thermal stability of AcT, crosslinked AcT and AcT-based conjugates}

Thermal stabilities of free, crosslinked AcT and AcT-based conjugates were investigated by incubating enzyme-containing solutions in a water bath at $75^{\circ} \mathrm{C}$. Samples were collected periodically, diluted, and the activity was evaluated as previously described. The activities of different enzyme compositions were compared to the free enzyme activity.

\subsection{Preparation of spores}

B. cereus 4342 was purchased from ATCC (USA) and cultured in nutrient broth $(3 \mathrm{~g} / \mathrm{L}$ beef extract, $5 \mathrm{~g} / \mathrm{L}$ peptone, Difco, USA) prepared in distilled water for $48 \mathrm{~h}$. The samples were next centrifuged at $3000 \mathrm{rpm}$ for $3 \mathrm{~min}$ and sporulation was induced by resuspending the cells in Difco Sporulation Media (DSM) at $37^{\circ} \mathrm{C}$ and $200 \mathrm{rpm}$ for $72 \mathrm{~h}$. All reagents were purchased from Sigma, unless otherwise specified. To terminate sporulation, the solution was centrifuged at $3000 \mathrm{rpm}$ for $3 \mathrm{~min}$ and the sediment was resuspended in distilled water; the procedure was repeated 5 times. Spore purity was determined by DIC confocal microscopy at $100 \times$ magnification (Nikon, $\mathrm{NY}$ ). The spores were visibly free of germinating cells and spore concentration was estimated using standard plate count technique. 


\subsection{Sporicidal efficiency of biocatalytic composites}

Enzyme-nanotube based composites were prepared as described previously [1,17]. Briefly, water-soluble crosslinked AcT-nanotube conjugates were mixed with eco-friendly paint (Freshaire Choice $^{\mathrm{TM}}$, with no volatile organic compounds, from ICI paints, Strongsville, OH, USA) in a glass vial $(2.5 \mathrm{~cm}$ diameter, VWR, USA). The mixture was air-dried for 2 days; the resulting composite had a thickness of $\sim 450 \mu \mathrm{m}$ as measured by surface profilometry (Dektak 8 Surface Profiler, Veeco Instruments Inc., Plainview, NY, USA). Decontamination of spores was evaluated by incubating $10^{6} \mathrm{CFU} / \mathrm{mL}$ spores with the AcT-based composite in a reaction mixture containing $100 \mathrm{mM}$ PGD and $100 \mathrm{mM} \mathrm{H}_{2} \mathrm{O}_{2}$ in $1 \mathrm{~mL}$ phosphate buffer ( $50 \mathrm{mM}, \mathrm{pH} 7)$, after shaking for $1 \mathrm{~h}$ at room temperature and $200 \mathrm{rpm}$. Aliquots from this reaction mixture were withdrawn periodically, diluted in phosphate buffer, spread onto a nutrient agar, and incubated at $37^{\circ} \mathrm{C}$ for $12 \mathrm{~h}$. Sporicidal efficiency was determined by counting colonies grown on the agar surface and by comparing corresponding colony counts with those obtained from different controls (paint and paint with reaction mixture without enzyme, respectively).

\section{Acknowledgements}

This work was supported by DTRA (HDTRA1-08-1-0022). We thank Gregg Whited and Karl Sanford (Genencor) for the gift of AcT.

\section{Appendix A. Supplementary data}

Supplementary data associated with this article can be found, in the online version, at doi:10.1016/j.molcatb.2011.11.003.

\section{References}

[1] C.Z. Dinu, G. Zhu, S.S. Bale, G. Anand, P.J. Reeder, K. Sanford, G. Whited, R.S Kane, J.S. Dordick, Adv. Funct. Mater. 20 (2010) 392-398.

[2] D.M. Portner, R.K. Hoffman, Appl. Environ. Microbiol. 16 (1968) 1782-1785.

[3] M.G.C. Baldry, J. Appl. Microbiol. 54 (1983) 417-423.

[4] D. Small, W. Chang, F. Toghrol, W. Bentley, Appl. Microbiol. Biotechnol. 76 (2007) 1093-1105.
[5] N.S. Amin, M.G. Boston, R.R. Bott, M.A. Cervin, E.M. Concar, M.E. Gustwiller, B.E Jones, K. Liebeton, G.S. Miracle, H. Oh, A.J. Poulose, S.W. Ramer, J.J. Scheibel, W. Weyler, G.M. Whited, in WIPO (Ed.), WO2005056782 (A2), C12n 9/00 ed., US 2006 .

[6] I. Mathews, M. Soltis, M. Saldajeno, G. Ganshaw, R. Sala, W. Weyler, M.A. Cervin, G. Whited, R. Bott, Biochemistry 46 (2007) 8969-8979.

[7] M.J. O'Connell, Carbon Nanotubes; Properties and Applications, 1 ed., CRC Taylor \& Francis, Boca Raton, 2006.

[8] A.M. Popov, Y.E. Lozovik, S. Fiorito, L. Yahia, Int. J. Nanomed. 2 (2007) 361-372

[9] M. Shim, N.W.S. Kam, R.J. Chen, Y.M. Li, H.J. Dai, Nano Lett. 2 (2002) 285-288.

[10] P. Asuri, S.S. Karajanagi, E. Sellitto, D.Y. Kim, R.S. Kane, J.S. Dordick, Biotechnol Bioeng. 95 (2006) 804-811.

[11] P. Asuri, S.S. Bale, R.C. Pangule, D.A. Shah, R.S. Kane, J.S. Dordick, Langmuir 23 (2007) 12318-12321.

[12] M. Fuentes, R.L. Segura, O. Abian, L. Betancor, A. Hidalgo, C. Mateo, R. FernandezLafuente, J.M. Guisan, Proteomics 4 (2004) 2602-2607.

[13] M.F. Verce, B. Jayaraman, T.D. Ford, S.E. Fisher, A.J. Gadgil, T.M. Carlsen, Environ. Sci. Technol. 14 (2008) 5765-5771.

[14] J.B.L. Harkness, A.A. Fridman, NCASI Tech. Bull. (1999).

[15] A.H. Mahvi, L. Diels, Int. J. Environ. Sci. Technol. 1 (2004) 199-204.

[16] L.A. Jury, J.L. Cadnum, A. Sanders-Jennings, E.C. Eckstein, S. Chang, C.J. Donskey, Am. J. Inf. Control 38 (2010) 234-236.

[17] I.V. Borkar, C.Z. Dinu, S.S. Bale, R.S. Kane, J.S. Dordick, Biotechnol. Prog. 26 (2010) $1622-1625$.

[18] T.C. Cheng, S.P. Harvey, G.L. Chen, Appl. Environ. Microbiol. 62 (1996) 1634-1641.

[19] W. Shang, J.H. Nuffer, J.S. Dordick, R.W. Siegel, Nano Lett. 7 (2007) 1991

[20] B.G. Davis, Curr. Opin. Biotechnol. 14 (2003) 379-386.

[21] L. Betancor, A. Hidalgo, G. Fernandez-Lorente, C. Mateo, R. Fernande-Lafuente, J.M. Guisan, Biotechnol. Prog. 19 (2003) 763-767.

[22] G. Penzol, P.A. Armisen, R. Fernández-Lafuente, L. Rodes, J.M. Guisán, Biotechnol. Bioeng. 60 (1998) 518-523.

[23] C.Z. Dinu, S.S. Bale, G. Zhu, J.S. Dordick, Small 5 (2009) 310-315

[24] P. Wang, M.V. Sergeeva, L. Lim, J.S. Dordick, Nat. Biotechnol. 15 (1997) 789793.

[25] S.J. Novick, J.S. Dordick, Chem. Mater. 10 (1998) 955-958.

[26] A.B. Iqbal Gill, Biotechnol. Bioeng. 70 (2000) 400-410.

[27] J. Kim, T.J Kosto.II., J.C. Manimala, E.B. Nauman, J.S. Dordick, AIChE J. 47 (2001) $240-244$.

[28] N. Vasileva, T. Godjevargova, V. Konsulov, A. Simeonova, S. Turmanova, J. Appl. Polym. Sci. 101 (2006) 4334-4340.

[29] C.S. McDaniel, J. McDaniel, M.E. Wales, J.R. Wild, Prog. Org. Coat. 55 (2006) $182-188$.

[30] X. Tong, A. Trivedi, H. Jia, M. Zhang, P. Wang, Biotechnol. Prog. 24 (2008) 714-719.

[31] S. Leaper, J. Food Technol. 19 (1984) 355-360.

[32] S. Leaper, J. Food Technol. 19 (1984) 695-702.

[33] A. Alasri, M. Valverde, C. Roques, G. Michel, C. Cabassud, P. Aptel, Can. J. Microbiol. 39 (1993) 52-60.

[34] J.A. Gerrard, P.K. Brown, S.E. Fayle, Food Chem. 79 (2002) 343-349. 